Universidade de São Paulo

Faculdade de Filosofia, Ciências e Letras de Ribeirão Preto

Departamento de Química

Programa de Pós-Graduação em Química

"Microdominios lipídicos ricos em fosfatase alcalina em filmes

Langmuir-Blodgett para obtenção de uma superfície de Ti osteoindutora"

Marco Aurélio Raz de Andrade

Dissertação de Mestrado apresentado à Faculdade de Filosofia, Ciências e Letras de Ribeirão Preto da Universidade de São Paulo, como parte das exigências para a obtenção do título de Mestre em Ciências, Área: Química.

Ribeirão Preto - SP 


\title{
"Microdominios lipídicos ricos em fosfatase alcalina em filmes Langmuir-Blodgett para obtenção de uma superfície de Ti osteoindutora"
}

\author{
(Versão Corrigida)
}

Marco Aurélio Raz de Andrade

Orientadora: Ana Paula Ramos

Coorientador: Pietro Ciancaglini

\begin{abstract}
Dissertação de Mestrado apresentado à Faculdade de Filosofia, Ciências e Letras de Ribeirão Preto da Universidade de São Paulo, como parte das exigências para a obtenção do título de Mestre em Ciências, Área: Química.
\end{abstract}

\section{Ribeirão Preto - SP}




\section{FICHA CATALOGRÁFICA}

Andrade, Marco Aurélio Raz

Microdomínios lipídicos ricos em fosfatase alcalina em filmes Langmuir-Blodgett para obtenção de uma superfície de Ti osteoindutora. Ribeirão Preto, 2017.

105 p. : il. ; $30 \mathrm{~cm}$

Dissertação de Mestrado, apresentada à Faculdade de Filosofia, Ciências e Letras de Ribeirão Preto/USP - Área de concentração: Química.

Orientadora: Ramos, Ana Paula.

1. Fosfatase Alcalina. 2. Filmes Langmuir-Blodgett. 3. Biomineralização. 
"Imaginação é mais importante que o conhecimento."

(Albert Einstein) 


\section{Dedicatória}

Dedico esta dissertação aos meus pais Antonio e Maria Estela, minha irmã Maria Júlia e minha namorada Camila, por todo o apoio durante esta jornada acadêmica. 


\section{Agradecimentos}

Primeiramente gostaria de agradecer minha orientadora, Prof. ${ }^{a}$ Dr. ${ }^{\text {a }}$ Ana Paula Ramos, não só pela íntegra disponibilidade e atenção durante a orientação, como também por confiar em mim na confecção do projeto de pesquisa e pela autonomia a mim conferida na condução do mesmo; além de desempenhar papel fundamental como exemplo de pessoa e de um profissional acadêmico. Gostaria de agradecer também meu co-orientador, Prof. Dr. Pietro Ciancaglini, por todo o auxilio durante meu mestrado em tudo o que está inserido dentro dos domínios da Bioquímica; outro exemplo (em versão internacional) ímpar como pessoa e como profissional.

Devo agradecer também a todos os meus familiares, em especial aos meus pais, Maria Estela e Antonio, e à minha irmã, Maria Júlia, que me apoiaram em todas as decisões da minha vida pessoal e acadêmica; vocês são meu porto seguro, a quem posso confiar e recorrer sempre em qualquer etapa da minha vida!..

Agradeço à minha namorada, Camila, por ter aparecido na minha vida e pelo apoio, carinho e tantos bons momentos proporcionados durante o período no qual estamos juntos; obrigado por estar ao meu lado em cada novo momento decisivo da minha jornada pessoal e acadêmica/profissional!..

Também devo agradecimentos especiais à Gilia, por me auxiliar nos passos iniciais das principais abordagens experimentais utilizadas neste projeto de pesquisa. Agradeço imensamente aos pós-graduandos Ana Maria e ao Bruno Favarin, pela colaboração nos experimentos bioquímicos e por toda a atenção; sem vocês, nada disto teria sido possível!..

Um agradecimento ao Lourivaldo e ao Rodrigo Silva, por toda a atenção e presteza durante as análises das amostras; vocês são exemplos de profissionais em uma instituição pública estadual!..

Agradeço a todos os meus colegas de trabalho, Anna Beatriz, Camila Bussola, Lucas Bahia, Marcos Antônio, Rafael Derradi, Tamires Maira, Thais Paterlini e Vanessa Comodaro; um muito obrigado por todos os momentos de distração e pelo auxílio em todas minhas dúvidas!..

Finalmente, agradeço a todos os meus colegas de graduação, ao Brian, Igor Gonzaga, Juliana e Naira (meu primeiro núcleo de amizades dentro da universidade), ao Ícaro, Douglas, Evandro, Bruno, Gabriel Panagassi, Victor Costacurta, Vanderlei, Matheus, e a todos os demais colegas de sala de aula. Agradeço também aos meus colegas Daniel Lima de Farias, Sayane, Felipe Brites, Flávia, André Pezzutto, Igor Sampaio, Malson, David Brito e Hudson Ferreira; pela amizade incondicional que não diminui com a distância, ao passo que esta só aumenta com o passar do tempo!..

(Agradeço também à FAPESP, pelo apoio financeiro durante o desenvolvimento do meu projeto de mestrado - Processo 2015/00345-3) 


\section{Índice}

Resumo

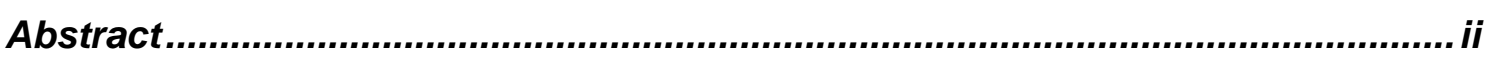

Índice de Figuras .........................................................................................

Índice de Tabelas................................................................................................ viii

Siglas e Abreviaturas ….............................................................................. ix

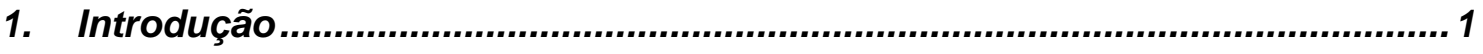

1.1. Histogênese do Tecido Ósseo........................................................................... 1

1.1.1 Regulação Celular .......................................................................................... 1

1.1.2 Constituição do Tecido Ósseo............................................................................ 2

1.1.3 Síntese da Parcela Inorgânica Mediada por Vesículas de Matriz ..................... 3

1.1.4 Fosfatase Alcalina Tecido Não-Específico …………………………………….... 4

1.2. Materiais Bioativos ................................................................................................... 8

1.2.1 Materiais Bioativos em Implantes Ósseos ...................................................... 8

1.2.2 Titânio como um Biomaterial ................................................................................... 9

1.3. Monocamadas de Langmuir................................................................................ 10

1.4. Caracterização das Monocamadas de Langmuir .................................................. 10

1.4 .1 Isotermas $\pi$ versus Área Molecular ................................................................... 10

1.4.2 Caracterização das Monocamadas de Langmuir por técnicas microscópicas

1.4.3 Pressão Superficial de Exclusão....................................................................... 14

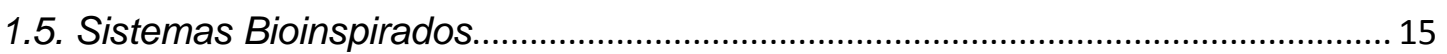

1.5.1 Sistemas Miméticos de Membrana Celular ....................................................... 15

1.5.2 Modificação Superficial de Ti com Filmes LB Híbridos ...................................... 18

1.6. Filmes Langmuir-Blodgett................................................................................ 19

1.6. Caracterização dos Filmes Langmuir-Blodgett................................................... 21

1.6.1 Razão de Transferência ...................................................................................... 21

1.6.2 Microgravimetria dos filmes LB .............................................................. 21

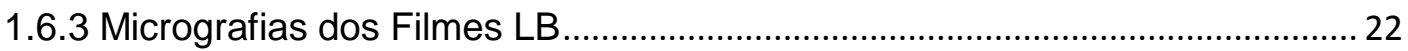

1.6.4 Caracterização Espectroscópica dos Filmes LB ……………………………. 23

1.6.5 Energia Livre Superficial das Superfícies Modificadas com Filmes LB ......... 23

1.7. Análise do Formato da Gota Eixo-Simétrico …………………………………….... 24

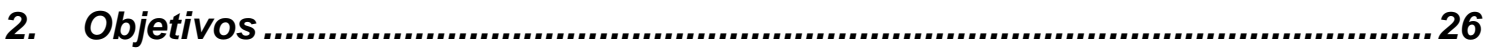

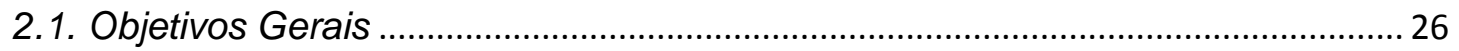


2.2. Objetivos Específicos 26

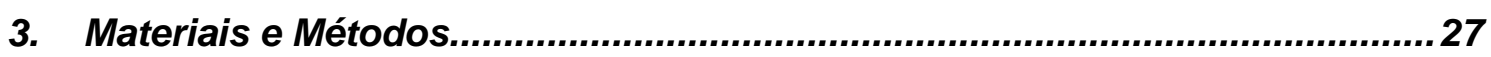

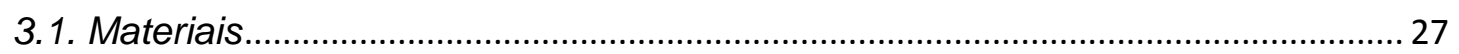

3.2. Obtenção da Fosfatase Alcalina Tecido Não-Específico ........................................ 27

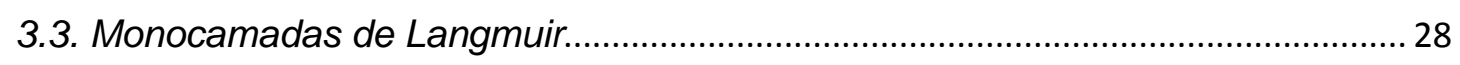

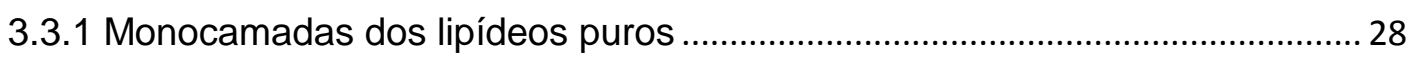

3.3.2 Atividade Superficial e Monocamadas de TNAP .............................................. 29

3.3.3 Monocamadas Mistas de Lipídeos e TNAP ...................................................... 30

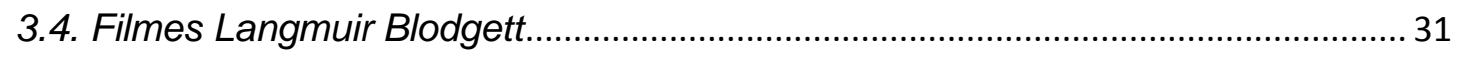

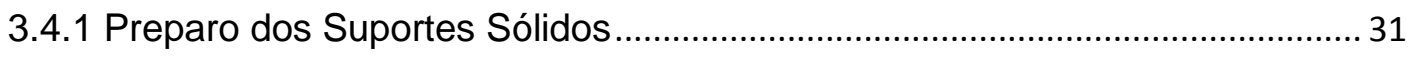

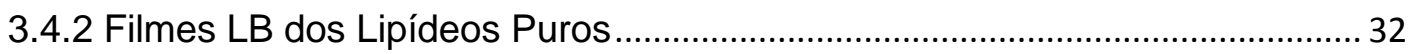

3.4.3 Filmes LB Mistos de Lipídeo e TNAP Fisicamente Adsorvida ......................... 32

3.4.4 Filmes LB Mistos de Lipídeo e TNAP ................................................................. 33

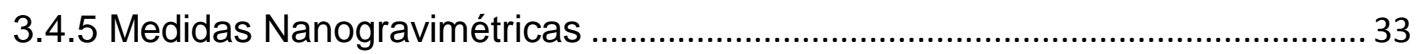

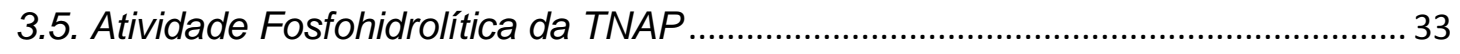

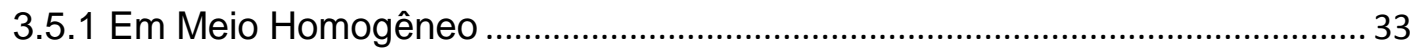

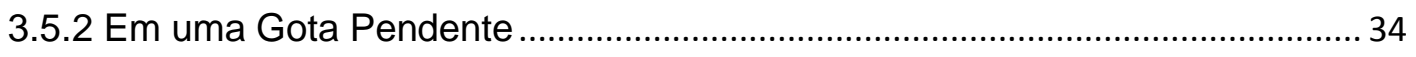

3.5.3 Imobilizada em Filmes Mistos de DMPA/Ca $\mathrm{Ca}^{2+} /$ TNAP....................................... 35

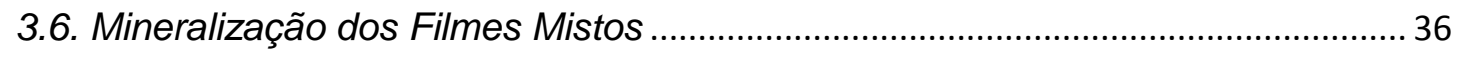

3.6.1 Análise da Formação de Mineral por Turbidimetria .......................................... 36

3.6.2 Análise Morfológica das Superfícies de Ti Modificadas ................................... 37

3.6.3 Análise Composicional das Superfícies de Ti Modificadas.............................. 37

3.6.4 Energia Livre Superficial e Molhabilidade......................................................... 37

3.6.5 Viabilidade Celular Sobre as Superfícies de Ti Modificadas ............................ 38

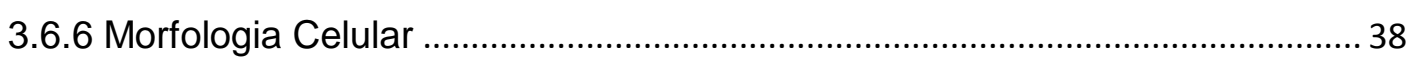

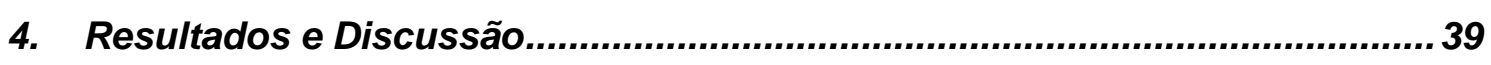

4.1. Caracterização das Monocamadas dos Lipídeos.................................................... 39

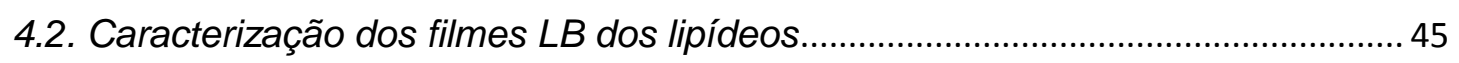

4.3. Caracterização da Atividade Superficial e das Monocamadas em presença de

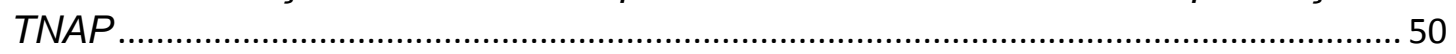

4.4. Caracterização das Monocamadas Mistas de TNAP e Lipídeos ........................... 53

4.5. Caracterização dos Filmes Mistos de TNAP e DMPA ........................................... 62

4.5.1 Imobilização de TNAP por meio de Adsorção Física ........................................62

4.5.2 Imobilização de TNAP a Partir das Monocamadas Mistas ............................... 64

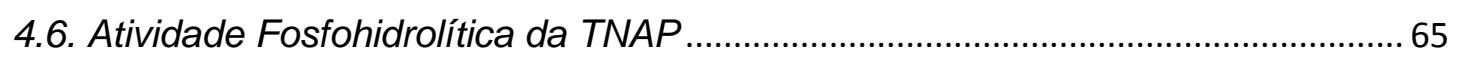

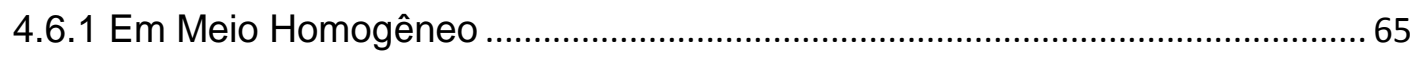

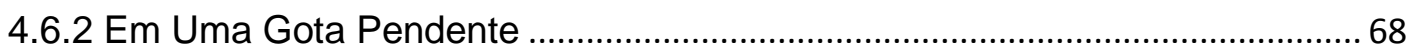




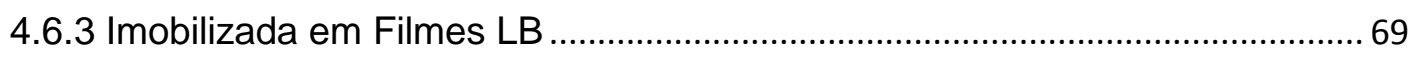

4.7. Mineralização dos Filmes Mistos de DMPA/Ca ${ }^{2+} / T N A P$........................................ 72

4.7.1 Filmes Confeccionados Através de Adsorção Física de TNAP ...................... 72

4.7.2 Filmes Confeccionados a Partir das Monocamadas Mistas de DMPA/TNAP .79

4.8. Cultivo de Osteoblastos sobre os Filmes de DMPA/Ca ${ }^{2+} / T N A P$............................ 85

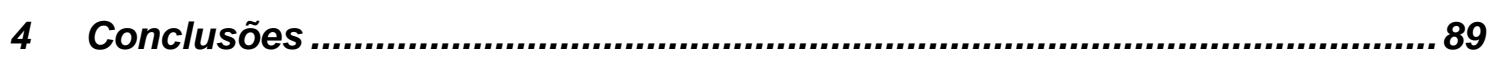

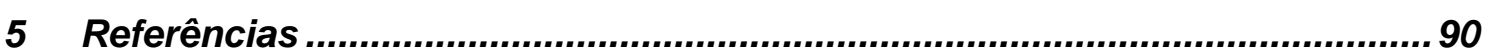




\section{Resumo}

ANDRADE, Marco A. R. Microdominios lipídicos ricos em fosfatase alcalina em filmes Langmuir-Blodgett para obtenção de uma superfície de Ti osteoindutora. 2017. 105 p. Dissertação (Mestrado) Faculdade de Filosofia, Ciências e Letras de Ribeirão Preto, Universidade de São Paulo, Ribeirão Preto, 2017.

Dentre os diversos processos de formação de mineral em organismos vivos, a formação do tecido ósseo é um exemplo particular, uma vez que fosfatos de cálcio, na forma de hidroxiapatita, são produzidos em meio a fibrilas de colágeno na matriz extracelular de células osteogênicas; processo este regulado por um complexo enzimático. A fosfatase alcalina tecido não-específico (TNAP) desempenha um papel fundamental na histogênese óssea, responsável principalmente pela produção de fosfato inorgânico necessário para a formação dos minerais. Diversas abordagens experimentais permitem a reconstituição desta enzima em sistemas miméticos de membrana celular, dentre os quais, os filmes Langmuir-Blodgett (LB), que possibilitam a formação de materiais com propriedades osteoindutoras. No presente estudo, foi investigada a imobilização desta enzima em filmes LB sobre suportes de Ti. O ácido dimiristoil fosfatídico foi o fosfolipídeo utilizado na confecção dos filmes LB, obtendo um regime de deposição linear de massa em função do número de camadas depositadas em subfases de $\mathrm{CaCl}_{2}$. A TNAP foi imobilizada nos filmes através de duas metodologias: a partir da adsorção física da enzima aos filmes LB pré-transferidos a um suporte sólido, ou ainda por meio da construção do filme a partir de uma monocamada mista de DMPA/ $\mathrm{Ca}^{2+} /$ TNAP. Em ambas as metodologias adotadas, foi obtida uma diminuição drástica da atividade fosfohidrolítica da forma imobilizada da enzima, em relação à sua atividade obtida em meio homogêneo. Ao expor suportes de Ti modificados com os filmes LB em uma solução contendo íons $\mathrm{Ca}^{2+}$ e ATP como fonte de fosfato inorgânico, foi observada a formação de uma maior quantidade de mineral para as amostras contendo a TNAP imobilizada; atribuída a uma maior supersaturação local de íons fosfato devido a maior hidrólise de ATP na presença da enzima, demonstrando a capacidade desta em conferir à superfície modificada uma maior capacidade na indução de formação de mineral. Após este ensaio de mineralização in vitro, foi obtida uma maior hidrofilicidade das superfícies recobertas com os filmes LB na presença da TNAP, tornando estas superfícies modificadas mais bioativas. A presença dos filmes LB mistos de lipídeo/TNAP nas superfícies permitiram a adesão, proliferação e recobrimento homogêneo de células osteogênicas, que posteriormente promoveram o extravasamento de fibrilas proteicas e a formação de nódulos de mineralização. Estes resultados são importantes na confecção de materiais que acelerem o processo de osteoindução.

Palavras chaves: 1. Fosfatase alcalina. 2. Filmes Langmuir-Blodgett. 3.

Biomineralização. 


\begin{abstract}
ANDRADE, Marco A. R. Lipid microdomains films rich in alkaline phosphatase in Langmuir-Blodgett to obtain a Ti surface osteoinductive. 2017. 105 p. Dissertação (Mestrado) Faculdade de Filosofia, Ciências e Letras de Ribeirão Preto, Universidade de São Paulo, Ribeirão Preto, 2017.
\end{abstract}

Among all the processes of mineral formation in living organisms, the osseous tissue formation is a particular example, since that calcium phosphates as hydroxyapatite are produced among collagen fibrils at the extracellular matrix of osteogenic cells, being this process regulated by an enzymatic complex. The tissue nonspecific alkaline phosphatase (TNAP) plays a central role on the osseous histogenesis, responsible mainly for the inorganic phosphate production necessary for mineral formation. Various experimental approaches allows this enzyme reconstitution in cellular membrane mimetic systems, among which, the Langmuir-Blodgett films (LB), that allows the formation of materials with osteoinductive properties. With that in mind, the immobilization of that enzyme in titanium supports modified with LB films was investigated. The dimyristoyl phosphatidic acid was the phospholipid used in the LB film construction, obtaining a linear deposition-layer numbers relation in $\mathrm{CaCl}_{2}$ subphases. The TNAP was immobilized at the films through two main methodologies: from the physical adsorption of the enzyme to the LB film pre-constructed on a solid support, or through the film construction from the mixed DMPA/ $\mathrm{Ca}^{2+} / \mathrm{TNAP}$ monolayer. At both the adopted methodologies, it was obtained a diminishment at the phosphohidrolytic activity of the immobilized enzyme, comparing to its activity at homogeneous media. Exposing the Ti supports with the LB films in a solution containing $\mathrm{Ca}^{2+}$ ions and ATP as a phosphate source, it was observed a higeher mineral formation to the samples containing the immobilized TNAP, possibly due to a higher phosphate ions supersaturation from the higher ATP hydrolysis at the presence of the enzyme, demonstrating the capacity of the TNAP in promoting a higher mineral formation induction to the modified surface. After this in vitro mineralization assay, it was obtained surfaces more hydrophilic at presence of the LB films containing TNAP, making those modified surfaces more bioactive. The mixed LB films presence at the surfaces allowed the adhesion, proliferation and homogeneous covering of osteogenic cells, that posteriorly promoted the production of proteic fibrils and mineralization nodules. Those results are important in order to construct materials more osteointegrative.

Keywords: 1. Alkaline phosphatase. 2. Langmuir-Blodgett films. 3. Biomineralization. 


\section{Índice de Figuras}

Figura 1 - Esquema da síntese e reabsorção óssea através da ação das células osteogênicas (modificado da referência [5]).....

Figura 2 - Diagrama esquemático da formação, orientação e dimensão dos cristais de fosfato de cálcio, relativo à direção das fibrilas de colágeno no tecido ósseo (modificado da referência [12]).

Figura 3 - Diagrama esquemático da regulação da formação e crescimento de HAP na matriz extracelular, mediada por um complexo enzimático presente no interior e membrana de vesículas de matrizes (modificado da referência [32]).

Figura 4 - Estrutura da PLAP com estruturas secundárias em representação de fitas (azul e verde) e modelos de bastões e esferas representando as cadeias laterais dos resíduos dos domínios N-terminal (vermelho), coroa (laranja) e de ligação dos metais (amarelo) (Modificado da referência [37]) (A), diagrama esquemático da TNAP ancorada à membrana celular através de suas âncoras GPI.

Figura 5 - Reação de hidrólise em meio básico do substrato sintético pNFF por meio da ação catalítica da TNAP, produzindo o produto cromogênico $\mathrm{pNF}^{-}$.

Figura 6 - Estrutura de uma âncora GPI da TNAP, destacando a cauda fosfolipídica contendo as cadeias hidrocarbônicas longas (R1 e R2) (púrpura), o núcleo glicano contendo as manoses (azul) e o grupo fosfoetanolamina (amarelo) covalentemente ligado à extremidade C-terminal da enzima.

Figura 7 - Isoterma $\pi$-A de uma monocamada de Langmuir arbitrária, destacando as diferentes fases e suas transições (modificado da referência [64]) (A) e isoterma $\pi$-A e valores de $\mathrm{CS}^{-1}$ de DPPC, destacando os parâmetros obtidos graficamente (B), Inserção: representação gráfica dos valores de $\mathrm{Cs}_{\mathrm{S}}^{-1}$ em função de $\pi$ ).

Figura 8 - Montagem experimental de um microscópio acoplado a uma cuba de Langmuir, com um diagrama esquemático da incidência da radiação eletromagnética p-polarizada, incidida em um determinado ângulo $\left(\theta_{\mathrm{B}}\right)$ com a normal à interface de Fresnel (reflexão nula), denominado ângulo de Brewster (Modificado da referência [86]).

Figura 9 - Imagens de micrografias de monocamadas de DPPC obtidas por: microscopia de fluorescência em subfase de $\mathrm{NaCl} 0,2 \mathrm{~mol} \mathrm{~L}^{-1} \mathrm{em} \pi=16,9 \mathrm{mN} \mathrm{m}^{-1}(\mathrm{~A})$, microscopia BAM em subfase de tampão fosfato $75 \mathrm{mmol} \mathrm{L}^{-1}\left(\mathrm{pH} \mathrm{7,4)} \mathrm{em} \pi=10 \mathrm{mN} \mathrm{m}^{-1}\right.$ (B) (Modificados das referências $[87,88])$.

Figura 10 - Representação da bicamada lipídica de uma membrana celular, contendo proteínas integrais (rosa) e regiões glicosiladas (preto) (extraído da referência [92])...... 16

Figura 11 - Diagrama esquemático da formação de um filme LB sobre um suporte sólido em subfase de $\mathrm{CaCl}_{2}$ seguida da exposição deste em solução SBF (Modificado da referência [63]).

Figura 12 - Diagrama esquemático da deposição de um filme LB a partir da emersão sobre um suporte sólido (A) e os diferentes tipos de filme LB encontrados (B) (modificado da referência [118])

Figura 13 - Esquema de uma cuba de Langmuir acoplada a um tensiômetro da placa de Wilhelmy e a um sistema dip-coater para a confecção de filmes LB. 
Figura 14 - Diagrama esquemático das forças entre as interfaces sólido-ar $\left(\gamma_{S V}\right)$, sólido-líquido $\left(\gamma_{\mathrm{SL}}\right)$ e líquido-ar $\left(\gamma_{\mathrm{LV}}\right)$, responsáveis pelo ângulo de contato da gota do líquido sobre a superfície sólida (Modificado da referência [130]).

Figura 15 - Fórmulas estruturais dos tensoativos utilizados na confecção das monocamadas de Langmuir e dos filmes LB.

Figura 16 - Diagrama esquemático dos experimentos DRUV-ADSA: (1) fonte de luz; (2) difusor; (3) gota pendente; (4) câmera CCD; (5) seringa; (6) microsseringa de injeção; (7) compudator; (I) fibra ótica-sonda de reflectância difusa; (II) lâmpadas de deutério/halogênio; (III) espectrofotômetro. 36

Figura 17 - Isotermas $\pi$-A (A) e valores de $\mathrm{CS}^{-1}$ em cada estágio de compressão (B) das monocamadas de DODAB obtidas em água pura (linha sólida) ou em $\mathrm{CaCl}_{2} 10 \mathrm{mmol} \mathrm{L}^{-1}$ (linha tracejada). Inserção: $\mathrm{C}_{\mathrm{S}}{ }^{-1} \mathrm{em}$ função de $\pi$. 40

Figura 18 - Isotermas $\pi$-A (A) e valores de $\mathrm{C}^{-1}$ em cada estágio de compressão (B) das monocamadas de DPPC obtidas em água pura (linha sólida) ou em $\mathrm{CaCl}_{2} 10 \mathrm{mmol} \mathrm{L}^{-1}$ (linha tracejada). Inserção: $\mathrm{Cs}^{-1}$ em função da pressão de superfície.

Figura 19 - Isotermas $\pi$-A (A) e valores de $\mathrm{Cs}^{-1}$ em cada estágio de compressão (B) das monocamadas de DMPA obtidas em água pura (preto), $\mathrm{CaCl}_{2} 0,1 \mathrm{mmol} \mathrm{L}^{-1}$ (vermelho) e $\mathrm{CaCl}_{2}$ $70 \mathrm{mmol} \mathrm{L}^{-1}$ (verde). Inserção: $\mathrm{CS}^{-1} \mathrm{em}$ função de $\pi$. 42

Figura 20 - Isotermas $\pi$-A (A) e valores de $\mathrm{C}_{S^{-1}}$ em cada estágio de compressão (B) das monocamadas de DMPA:Chol obtidas em água pura nas proporções de 1:0 (preto), 4:1 (vermelho), 1:1 (verde), 1:4 (azul) e púrpura (0:1). 44

Figura 21 - Massas de DODAB depositado sobre cristal de quartzo recoberto com ouro em função do número de camadas, a partir de uma subfase de água pura. Os números sobre os pontos representam a razão de transferência de cada deposição. 45

Figura 22 - Massas de DPPC depositado sobre cristal de quartzo recoberto com ouro em função do número de camadas, a partir de uma subfase de água pura $(\bullet)$ ou de $\mathrm{CaCl}_{2} 10 \mathrm{mmol}$ $\mathrm{L}^{-1}(\mathrm{\circ})$. Os números sobre os pontos representam a razão de transferência de cada deposição. . 46

Figura 23 - Massas de DMPA depositado sobre cristal de quartzo recoberto com ouro em função do número de camadas, a partir de uma subfase de água pura $(\bullet), \mathrm{CaCl}_{2} 0,1 \mathrm{mmol} \mathrm{L}^{-1}$ (०) e $70 \mathrm{mmol} \mathrm{L}^{-1}(\mathbf{\square})$. Os números sobre os pontos representam a razão de cada deposição.... 47

Figura 24 - Módulos compressionais em função da pressão de superfície das monocamadas de DODAB (preto), DPPC (vermelho) em $\mathrm{CaCl}_{2} 10$ mmol L-1 e DMPA (verde) em $\mathrm{CaCl}_{2} 0,1$ $\mathrm{mmol} \mathrm{L}-1$

Figura 25 - Variação de $\pi$ em uma gota de água pós-injeção de 8,5 ng de TNAP (A) e isotermas $\pi$-A obtidas pós-espalhamento de $375 \mathrm{ng}$ de TNAP em cuba de Langmuir em água pura (B), na ausência (linha sólida) e presença (linha tracejada) de polidocanol 1\% p/V . 51

Figura 26 - Isoterma $\pi-\mathrm{A}$ de $18 \mu \mathrm{g}$ de TNAP na ausência de polidocanol espalhada sobre

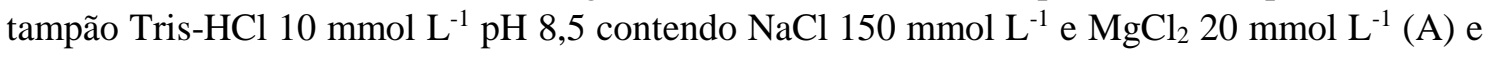
valores de $\mathrm{CS}^{-1}$ em função de $\pi(\mathrm{B})$ 51

Figura 27 - Isotermas $\pi$-A (A) de 5,7 $\mu$ g de TNAP na ausência de polidocanol espalhada sobre subfases de $\mathrm{CaCl}_{2} 60$ (preto), 80 (vermelho) e 90 (verde) $\mathrm{mmol} \mathrm{L}^{-1}$, em água pura (azul) e valores de $\mathrm{C}_{S}^{-1}$ em função de $\pi(\mathrm{B})$. 52 
Figura 28 - Isotermas $\pi$-A de DPPC puro (preto), com TNAP na ausência (vermelho) e presença (verde) de polidocanol 1\% p/V, em subfase de água pura contendo $375 \mathrm{ng}$ da enzima.

Figura 29 - Isotermas $\pi$-A de DPPC (A) e DMPA (B) em subfases de tampão Tris-HCl 10 mmol L-1 contendo $\mathrm{NaCl} 150 \mathrm{mmol} \mathrm{L}^{-1}$ e $\mathrm{MgCl}_{2} 20 \mathrm{mmol} \mathrm{L}^{-1}$, na ausência (linha sólida) e presença (linha tracejada) de 12,6 $\mu \mathrm{g}$ de TNAP na ausência de polidocanol, co-espalhada com os lipídeos

Figura 30 - Isotermas $\pi$-A (A) e valores de $\mathrm{C}_{S^{-1}}$ em função de $\pi$ (B) de monocamadas de DMPA, em subfases de água (preta) e em $\mathrm{CaCl}_{2} 70 \mathrm{mmol} \mathrm{L}^{-1}$ na ausência (vermelha) e presença (verde) de 5,7 $\mu$ g de TNAP (sem polidocanol) 55

Figura 31 - Isotermas $\pi$-A (A) e valores de $\mathrm{Cs}^{-1}$ em função de $\pi$ (B) de monocamadas de DMPA em subfase de $\mathrm{CaCl}_{2} 70 \mathrm{mmol} \mathrm{L}^{-1}$ na ausência e presença de diferentes razões molares de TNAP:DMPA (sem polidocanol)

Figura 32 - Variação de $\pi$ em função do tempo para monocamadas de DMPA em subfase de $\mathrm{CaCl}_{2} 70 \mathrm{mmol} \mathrm{L}^{-1}$ na ausência e presença de diferentes razões molares de TNAP:DMPA (sem polidocanol) (A) e ciclos de compressão e expansão de isoterma $\pi$-A de monocamada mista de TNAP:DMPA 1:1400 em subfase de $\mathrm{CaCl}_{2} 70 \mathrm{mmol} \mathrm{L}^{-1}$ (B). 56

Figura 33 - Imagens de microscopia BAM de monocamadas de DMPA em $\mathrm{CaCl}_{2} 70 \mathrm{mmol} \mathrm{L}^{-1}$, na ausência e presença de TNAP (razão molar TNAP:DMPA 1:1400), em diferentes estágios de compressão.

Figura $34-\Delta \pi$ da monocamada de DMPA, a partir de diferentes valores de $\pi_{\text {inicial }}$ com a injeção de TNAP (sem polidocanol, até obter razão molar TNAP:DMPA 1:1400) em subfase de $\mathrm{CaCl}_{2} 70 \mathrm{mmol} \mathrm{L}^{-1}$ (A) e representação gráfica dos valores de $\Delta \pi$ em função de $\pi_{\text {inicial }}(\mathrm{B})$. Inserção: Variação de $\pi$ em função do tempo ao injetar 2,8 $\mu \mathrm{g}$ de TNAP (sem polidocanol) em $\mathrm{CaCl}_{2} 70 \mathrm{mmol} \mathrm{L}^{-1}$.

Figura $35-\Delta \pi$ das monocamadas mistas de DMPA:Chol, nas proporções de 1:0 (•), 4:1 (०) e 1:1 (๘), a partir de diferentes valores de $\pi_{\text {inicial }}$ com a injeção de TNAP (sem polidocanol, razão molar TNAP:lipídeos 1:1400) em subfase de $\mathrm{CaCl}_{2} 70 \mathrm{mmol} \mathrm{L}^{-1}$

Figura 36 - Quantificação da massa de DMPA/Ca ${ }^{2+}(\mathrm{n}=3)$ imobilizado sobre um cristal de quartzo recoberto com ouro, ao ser exposto a uma solução de TNAP 2,64 $\mu \mathrm{g} \mathrm{mL}^{-1}$ por diferentes intervalos de tempo.

Figura 37 - Massa dos filmes mistos $(\Delta \mathrm{m})$ em função da razão molar de TNAP:DMPA nas monocamadas mistas (A) e da expansão de área provocada pela enzima na monocamada de DMPA (B). 64

Figura 38 - Concentrações de TNAP em diferentes ensaios pós-remoção do polidocanol, com valor médio de concentração proteica (linha tracejada). 66

Figura 39 - Análise cinética contínua em meio homogêneo: Espectros UV-Vis da formação de pNF- obtidos em intervalos de tempo de 2 minutos (A) e valores de atividades específica da TNAP (sem polidocanol) em função do tempo de estocagem (B). Inserção: valores de absorção em $410 \mathrm{~nm}$ em função do tempo de reação. 66

Figura 40 - Valores normalizados de atividade específica pNFFase da TNAP em meio homogêneo, na ausência e presença de gentamicina e fungizona. 67 
Figura 41 - Valores de absorbância e concentrações de $\mathrm{pNF}^{-}$no meio reacional contendo 0,528 $\mu \mathrm{g}$ de TNAP (sem polidocanol) através de espectrofotometria tradicional em uma cubeta (A) e através de DRUV em uma gota pendente (B). 68

Figura 42 - Espectros UV-Vis do $\mathrm{pNF}^{-}$em intervalos de tempo de 0 (preto), 2 (vermelho) e 5 (verde) minutos após injeção de 13,2 ng de TNAP (sem polidocanol) em uma gota de meio reacional (A) e valores de absorção em $410 \mathrm{~nm}$ e quantidades de $\mathrm{pNF}^{-}$equivalentes a partir destes espectros. Inserção: espectros UV-Vis de $\mathrm{pNF}^{-}$normalizados, obtidos por espectrofotometria tradicional (preto) e por DRUV (vermelho).

Figura 43 - Valores de atividade pNFFase de TNAP imobilizada em filmes LB mistos de TNAP/DMPA: em função das expansões provocadas pela enzima (em $\pi=30 \mathrm{mN} \mathrm{m}^{-1}$ ) sobre as monocamadas de DMPA (A) e do filme construído a partir de monocamada de TNAP:DMPA 1:1400 em função do tempo (B). 71

Figura 44 - Valores de absorbância em $340 \mathrm{~nm}$ do meio de SCL após exposição de filmes LB de DMPA/ $\mathrm{Ca}^{2+}$ na ausência ( $\square$ ) ou presença ( $\bullet$ de TNAP fisicamente adsorvida 73

Figura 45 - Micrografias de MEV de superfícies de Ti modificadas com filmes LB de DMPA/Ca ${ }^{2+}$ na ausência (A,C,E) e presença (B,D,F) de TNAP fisicamente adsorvida, após 28 dias de exposição a SCL. Inserção (C,D): Detalhamento das partículas formadas na superfície.

Figura 46 - Micrografias de MEV composicional de superfícies de Ti modificadas com filmes LB de DMPA/ $\mathrm{Ca}^{2+}$ na ausência (A) e presença (B) de TNAP fisicamente adsorvida, após 28 dias de exposição a SCL

Figura 47 - Espectros de EDS das superfícies de Ti representadas na Figura 39: (A) referente à Figuras 46A, (B) e (C) referentes às regiões 2 e 3 da Figura 46B, respectivamente.................... 76

Figura 48 - Espectros de ATR-FTIR de superfícies de Ti modificadas com filmes LB de DMPA/ $\mathrm{Ca}^{2+}$ na ausência e presença de TNAP fisicamente adsorvida, após 28 dias de exposição a SCL

Figura 49 - Padrões de difração de: superfícies de Ti modificadas com filmes LB de DMPA/Ca ${ }^{2+}$ na ausência (linha preta) e presença (linha vermelha) de TNAP fisicamente adsorvida, após 28 dias de exposição a SCL (A) e ampliação da região contendo picos relacionados ao mineral e comparação com os picos presentes no padrão de difração de $\mathrm{Ca}_{3} \mathrm{PO}_{4}$ (linha azul). Os picos marcados com + correspondem ao suporte de Ti.

Figura 50 - Valores de absorbância em $340 \mathrm{~nm}$ do meio de SCL após exposição de filmes LB de DMPA $/ \mathrm{Ca}^{2+}$ na ausência ou presença de diferentes razões molares TNAP:DMPA (indicadas na figura) sobre subfase de $\mathrm{CaCl}_{2} 70 \mathrm{mmol} \mathrm{L}^{-1}$ 79

Figura 51 - Micrografias de MEV de superfícies de Ti modificadas com filmes LB de DMPA/ $\mathrm{Ca}^{2+}$ na ausência $(A, C)$ e presença $(B, D)$ de TNAP imobilizada a partir de monocamada mista de TNAP:DMPA 1:900, após 6 dias de exposição a SCL

Figura 52 - Micrografia de MEV composicional de superfície de Ti modificada com filme LB de DMPA $/ \mathrm{Ca}^{2+}$ na presença de TNAP imobilizada a partir de monocamada mista de TNAP:DMPA 1:900, após 6 dias de exposição a SCL.

Figura 53 - Espectro de EDS da superfície de Ti, referente à região 1 representada na Figura 52.

Figura 54 - Espectros de ATR-FTIR de superfícies de Ti modificadas com filmes LB de DMPA/Ca ${ }^{2+}$ na ausência ou presença de TNAP imobilizada a partir de monocamadas mistas 
com diferentes razões molares TNAP:DMPA (indicadas na figura), após 6 dias de exposição a SCL.

Figura 55 - Padrões de difração de superfícies de Ti modificadas com filmes LB de DMPA $/ \mathrm{Ca}^{2+}$ na ausência ou presença de TNAP imobilizada a partir de monocamadas mistas com diferentes razões molares TNAP:DMPA (indicadas na figura), após 6 dias de exposição a SCL. 84

Figura 56 - Viabilidade celular obtida para cultura de osteoblastos em função do tempo na presença de discos de Ti sem modificações (preto) e modificados com filmes LB de DMPA $/ \mathrm{Ca}^{2+}$ na ausência (cinza) e presença (branco) de TNAP imobilizada, a partir de

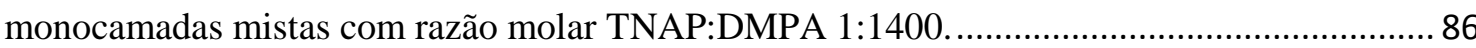

Figura 57 - Micrografias de MEV após 3 dias de cultura de osteoblastos sobre superfícies de Ti sem modificações e modificados com filmes LB de DMPA/Ca ${ }^{2+}$ na ausência e presença de TNAP imobilizada, a partir de monocamadas mistas com razão molar TNAP:DMPA 1:1400. 87

Figura 58 - Micrografias de MEV após 10 dias de cultura de osteoblastos sobre superfícies de Ti sem modificações e modificados com filmes LB de DMPA/Ca ${ }^{2+}$ na ausência e presença de TNAP imobilizada, a partir de monocamadas mistas com razão molar TNAP:DMPA 1:1400. 88 


\section{Índice de Tabelas}

Tabela 1 - Valores de $\mathrm{C}_{S}{ }^{-1}$ para as diferentes fases de uma monocamada

Tabela 2 - Módulos compressionais em $\pi=30 \mathrm{mN} \mathrm{m}^{-1}$ e área molecular média para as monocamadas de Langmuir em diferentes subfases

Tabela 3 - Taxas de transferência de massa dos filmes LB dos lipídeos em função do número de camadas, obtidos em diferentes condições

Tabela 4 - Valores de pressões de exclusão para monocamadas mistas de DMPA/Chol em diferentes proporções e valores de $\mathrm{C}_{\mathrm{S}}{ }^{-1}$ nas pressões de exclusão....

Tabela 5 - Quantificação de massa de DMPA/Ca ${ }^{2+}$ em filmes mistos com diferentes razões de TNAP:DMPA co-espalhadas na interface. 65

Tabela 6 - Atividades específicas de TNAP em meio homogêneo para diferentes condições experimentais 67

Tabela 7 - Valores de atividades específicas pNFFase $\left(\mathrm{A}_{\mathrm{imob}}\right)$, densidade superficial $\left(\mathrm{D}_{\text {sup }}\right)$ e área molecular superficial ( $\mathrm{A}_{\text {sup }}$ ) da TNAP fisicamente adsorvida em filmes LB de DMPA/Ca ${ }^{2+}$ com diferentes números de camadas, e comparação com a atividade em meio homogêneo (Ahomog)

Tabela 8 - Atividade fosfohidrolítica e parâmetros de deposição da TNAP imobilizada em filmes LB de DMPA/Ca ${ }^{2+}$ confeccionados a partir das monocamadas mistas contendo diferentes razões TNAP:DMPA

Tabela 9 - Ângulo de contato de água (AC), energia livre de superfície $\left(\gamma_{S}\right)$ e suas componentes polar $\left(\gamma_{\mathrm{P}}\right)$ e dispersiva $\left(\gamma_{\mathrm{D}}\right)$ de superfícies de Ti modificadas com filmes LB de DMPA/Ca ${ }^{2+}$ na ausência ou presença de TNAP imobilizada a partir de monocamadas mistas com diferentes razões molares TNAP:DMPA, após 6 dias de exposição a SCL 84 


\section{Siglas e Abreviaturas}

ADSA

AMPOL

AMP

ADP

ATP

ATR

BAM

$\mathrm{C}_{12}(\mathrm{EO})_{9}$

Chol

DMPA

DODAB

DPPC

DRUV

DRX

FTIR

$\gamma$

GPI

HAP

$\mathrm{MeOH}$

MEV

MTT
Análise do Formato da Gota

Eixossimétrico

2-Amino-2-Metil Propan-1-ol

Adenosina Monofosfato

Adenosina Difosfato

Adenosina Trifosfato

Reflectância Total Atenuada

Microscopia no Ângulo de Brewster

Polioxietileno 9-Lauril Éter

Colesterol

Ácido Dimiristoil Fosfatídico

Brometo de di-Octadecil di-Metil Amônio

Dipalmitoil Fosfatidilcolina

Espectrofotometria UV-Vis por

Reflectância Difusa

Difração de Raios X

Espectroscopia de Infravermelho com

Transformada de Fourier

Tensão Superficial

Glicosilfosfatidilinositol

Hidroxiapatita

Metanol

Microscopia Eletrônica de Varredura

3[4,5-dimetiltiazol-2-il]-2,5-brometo 
difenil tetrazolium

VMs

NPP1

$\pi$

Pchol

PEA

$\pi_{\mathrm{exc}}$

$\mathrm{P}_{\mathrm{i}}$

pNFF

$\mathrm{pNF}^{-}$

$\mathrm{PP}_{\mathrm{i}}$

PS

QCM

$\mathrm{R}_{\text {transf. }}$

SBF

SCL

TNAP

Tris
Vesículas de Matriz

Nucleotídeo

Pirofosfatase/Fosfodiesterase-1

Pressão de Superfície

Fosfocolina

Fosfatidiletanolamina

Pressão Superficial de Exclusão

Fosfato Inorgânico

p-Nitrofenil Fosfato

p-Nitrofenolato

Pirofosfato Inorgânico

Fosfatidilserina

Micro balança à Cristal de Quartzo

Razão de Transferência

Fluido Corpóreo Simulado

Linfa de Cartilagem Sintética

Fosfatase Alcalina Tecido Não-Específico

Tris(hidroximetil)aminoetano 
Introdução 


\section{Introdução}

\subsection{Histogênese do Tecido Ósseo}

\subsubsection{Regulação Celular}

A formação do tecido ósseo caracteriza um exemplo particular da formação de minerais em um tecido conjuntivo, resultando em um compósito com propriedades únicas e distintas das parcelas orgânicas e inorgânicas que o constitui, em proporção de 20 e $72 \%$ em peso, respectivamente [1]. A matriz orgânica contempla não somente um conjunto de proteínas como também um grupo de células responsáveis pela histogênese; desde a produção das proteínas e minerais durante a formação do osso até sua preservação. A parcela inorgânica é formada por meio da nucleação e crescimento de fosfatos de cálcio, um processo iniciado em vesículas secretadas pelas células osteogênicas e propagado na matriz óssea (denominada de osteóide) de maneira orientada pelas proteínas (também produzidas por este conjunto celular) [2].

As células osteogênicas provêm da diferenciação de células mesenquimais e são responsáveis pela síntese, manutenção e reabsorção da matriz óssea (Figura 1). Dentre elas, os osteoblastos são células especializadas responsáveis pela síntese, secreção e mineralização da matriz óssea [3], protagonista na ossificação intramembranosa. Os condrócitos também atuam na liberação dos componentes da matriz extracelular durante a ossificação do tipo endocondral [4].

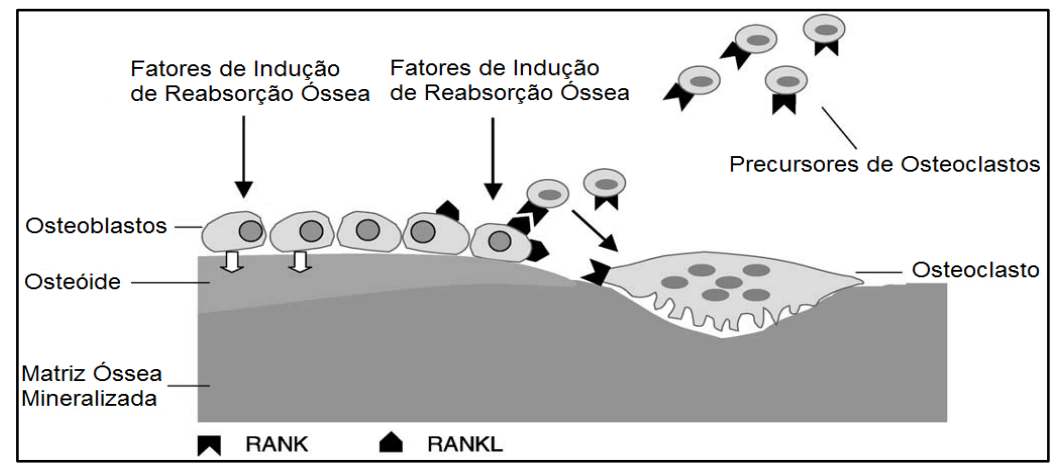

Figura 1 - Esquema da síntese e reabsorção óssea através da ação das células osteogênicas (modificado da referência [5]). 
Antagonicamente, os osteoclastos atuam na desmineralização ácida e degradação dos componentes orgânicos do tecido ósseo, promovendo sua reabsorção [6], exercendo um papel importante na homeostase de $\mathrm{Ca}^{2+}$ sanguíneo hormônio-regulada [7]. A oclusão de uma fração dos osteoblastos ativos na matriz extracelular resulta no surgimento de uma classe celular denominada de osteócitos [8], as células mais abundantes nos ossos e que atuam na nutrição e manutenção deste.

\subsubsection{Constituição do Tecido Ósseo}

Juntamente com algumas glicoproteínas e proteoglicanas, o colágeno é a proteína majoritária na composição da parcela orgânica do tecido ósseo. A estrutura quaternária do colágeno apresenta um peso molecular de aproximadamente $300 \mathrm{kDa}$, um comprimento e diâmetro de aproximadamente 300 e 1,36 nm respectivamente [9]; formada por três cadeias polipeptídicas estruturadas em uma torção das hélices, cada qual contém uma sequência de 1014 aminoácidos com uma glicina a cada três resíduos [10]. Cerca de $95 \%$ da matriz orgânica dos ossos é constituída por colágeno do tipo-I, constituído de duas cadeias idênticas (denominadas $\alpha 1$ ) e uma terceira cadeia distinta (denominada $\alpha 2$ ), com diferenças na composição aminoacídica [11]. A rede colagenosa orienta a formação dos cristais de fosfato de cálcio nos poros e vacâncias (de dimensões de 5 x $40 \mathrm{~nm}$ ) presentes nas fibrilas proteicas [12] (Figura 2); em uma nucleação heterogênea e catalisada pela presença de grupos carboxilas [13], presentes nos resíduos de ácido aspártico e glutâmico distribuídos no colágeno por aproximadamente 11,3 nm [10].

Correspondendo à maior parcela de massa do tecido ósseo, a matriz inorgânica é constituída por fosfatos de cálcio, com a estrutura e razão $\mathrm{Ca} / \mathrm{P}$ (próximo de 1,65 ) da hidroxiapatita (HAP), $\mathrm{Ca}_{10}\left(\mathrm{PO}_{4}\right)_{6}(\mathrm{OH})_{2}$; podendo apresentar outros íons como $\mathrm{Mg}^{2+}$, $\mathrm{Na}^{+} \mathrm{e} \mathrm{CO}_{3}{ }^{2-}(0,6,1$ e $5 \% \mathrm{~m} / \mathrm{m}$, respectivamente $)$ em quantidades significativas [1], ou como traços $\left(\mathrm{Cl}^{-}, \mathrm{F}^{-}, \mathrm{K}^{+}, \mathrm{Sr}^{2+}\right)$ [14] em sua estrutura. $\mathrm{O}$ carbonato pode estar presente na estrutura da HAP, majoritariamente no interior dos cristais bem como em sua superfície [15], por meio da substituição de íons $\mathrm{OH}^{-}$ou de $\mathrm{PO}_{4}^{3-}$, denominadas substituições dos tipos A e B, respectivamente [16]; ambas encontradas no mineral constituinte da matriz óssea [17]. O tipo de substituição pode ser diferenciado por técnicas espectroscópicas, como FTIR [18]. Os cristais de HAP carbonatada apresentam uma superfície consideravelmente polar, com altos valores de área $\left(100-200 \mathrm{~m}^{2} \mathrm{~g}^{-1}\right)$, permitindo a 
formação de ligações intermoleculares fortes com moléculas polares/polarizáveis, o que favorece a interação com os grupos polares do colágeno [19].

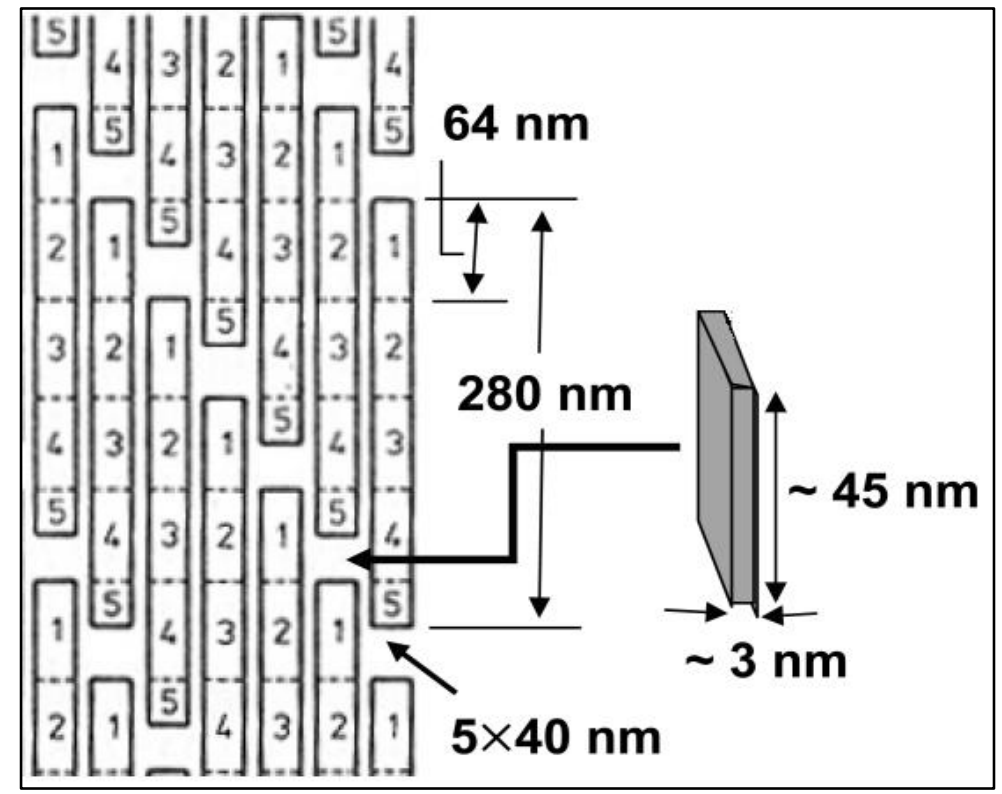

Figura 2 - Diagrama esquemático da formação, orientação e dimensão dos cristais de fosfato de cálcio, relativo à direção das fibrilas de colágeno no tecido ósseo (modificado da referência [12]).

\subsubsection{Síntese da Parcela Inorgânica Mediada por Vesículas de Matriz}

O processo de mineralização da matriz extracelular inicia-se com a nucleação por meio da supersaturação local de $\mathrm{P}_{\mathrm{i}}$ e $\mathrm{Ca}^{2+}$, formando cristais a partir dos quais haverá o crescimento do mineral. Diferentes teorias são propostas acerca destas duas etapas essenciais na formação e crescimento dos minerais [20-22]. A teoria da nucleação de cristais de HAP no interior de vesículas e propagação entre as fibrilas de colágeno é uma das mais aceitas [2]. As vesículas de matriz (VMs) são estruturas compartimentalizadas (diâmetro de aproximadamente $100 \mathrm{~nm}$ ) secretadas pelas células osteogênicas (condrócitos, osteoblastos e odontoblastos) [2,23], presentes em vários tecidos sob mineralização [24]. As MVs contém um complexo enzimático tanto em seu interior como na sua membrana (Figura 3), que atua no transporte iônico e na catálise de reações essenciais para a biomineralização de HAP na matriz óssea.

A formação de HAP mediada por vesículas de matriz pode ser entendida através de dois principais processos: (I) aumento na quantidade de compostos com afinidade por $\mathrm{Ca}^{2+}$ (principalmente fosfatidilserina e anexinas), influxo deste íon nas MVs através de canais iônicos e maior atividade fosfohidrolítica de enzimas presentes na membrana 
das vesículas [2], com destaque para a ação da enzima PHOSPHO1 na geração de $\mathrm{P}_{\mathrm{i}}$, a partir da catálise da hidrólise de fosfocolina (Pchol) e fosfoetanolamina (PEA) [25], no interior das MVs [26]; (II) propagação do mineral na matriz extracelular de maneira orientada longitudinalmente pelo arranjo das moléculas de colágeno, nas vacâncias entre as fibrilas e em regiões contendo aminoácidos polares [27]. Nesta segunda etapa é fundamental a supersaturação local de íons $\mathrm{Ca}^{2+}$ e Pi durante o crescimento dos minerais, garantida pela presença dos mesmos no fluido extracelular [2]; bem como o controle da concentração de inibidores deste processo, como o pirofosfato $\left(\mathrm{PP}_{\mathrm{i}}\right)$ [28]. A razão das concentrações de $\mathrm{P}_{\mathrm{i}} / \mathrm{PP}_{\mathrm{i}}$ é, portanto, essencial para a propagação de $\mathrm{HAP}$ na matriz colagenosa, uma vez que representa o balanço na quantidade entre o íon necessário na precipitação dos cristais $\left(\mathrm{P}_{\mathrm{i}}\right)$ e o inibidor deste processo $\left(\mathrm{PP}_{\mathrm{i}}\right)$. Este balanço é realizado por duas enzimas presentes na superfície das MVs, a fosfatase alcalina tecido não-específica (TNAP) [29] e a nucleotídeo pirofosfatase/fosfodiesterase-1 (NPP1) [30], que atuam antagonicamente [31]: enquanto a NPP1 produz $\mathrm{PP}_{\mathrm{i}}$ a partir de substratos fosforilados a TNAP catalisa a hidrólise deste inibidor de mineralização (bem como de outros substratos fosforilados), aumentando a concentração de $\mathrm{P}_{\mathrm{i}}$ e favorecendo a propagação do mineral (Figura 3).

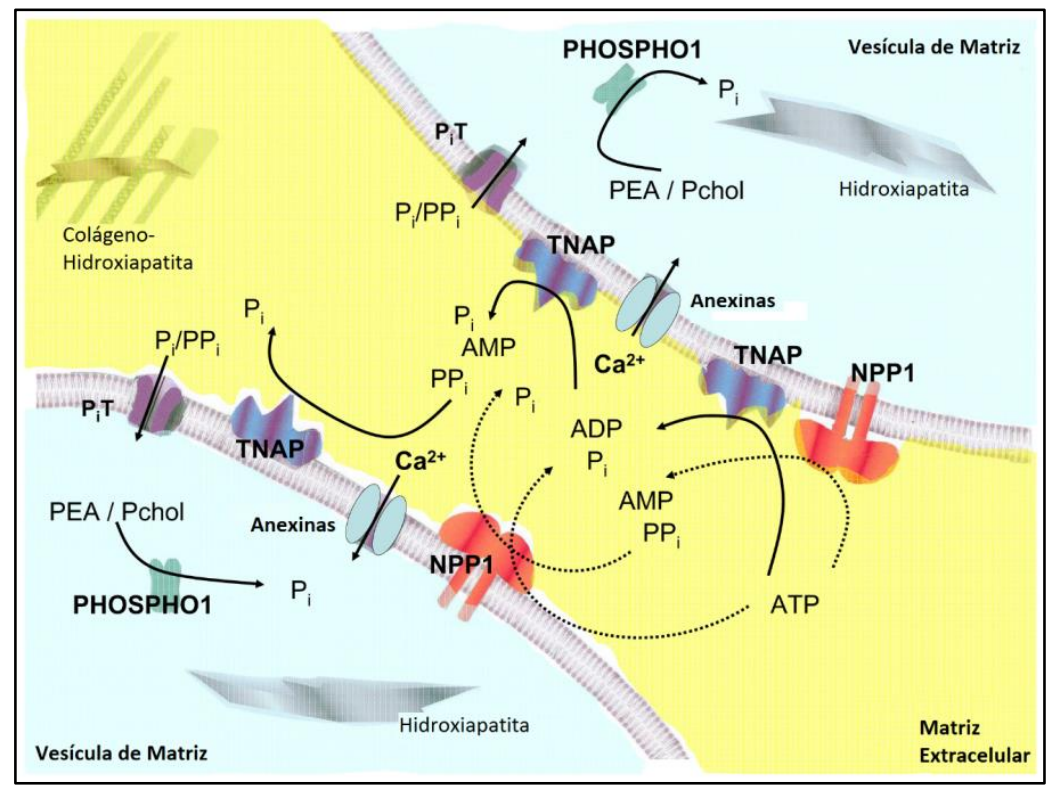

Figura 3 - Diagrama esquemático da regulação da formação e crescimento de HAP na matriz extracelular, mediada por um complexo enzimático presente no interior e membrana de vesículas de matrizes (modificado da referência [32]).

\subsubsection{Fosfatase Alcalina Tecido Não-Específico}


A TNAP (P05186) é uma enzima-chave na mineralização do tecido ósseo, devido à sua atividade fosfohidrolítica em substratos fosforilados, liberando fosfato inorgânico que permite supersaturação local de íons $\mathrm{P}_{\mathrm{i}}$ que, em conjunto com íons $\mathrm{Ca}^{2+}$, irão formar cristais de HAP. É uma isoenzima homodimérica, apresentando cerca de 950 resíduos de aminoácidos e peso molecular de $115 \mathrm{kDa}$ [33], encontrada em humanos no osso, fígado e rins.

Pertence à família de enzimas que catalisam reações de hidrólise (ou transferência de $\mathrm{P}_{\mathrm{i}}$ ) de monoésteres de ácido fosfórico, contendo três íons metálicos necessários para a atividade enzimática [34] (dois $\mathrm{Zn}^{2+}$ e um $\mathrm{Mg}^{2+}$ ), coordenados com resíduos de aminoácido (consideravelmente conservados entre diferentes espécies) de seu sítio ativo [35]. Neste sítio, um resíduo de serina é ativado por um íon $\mathrm{Zn}^{2+}$ e torna-se fosforilado (através de um $\mathrm{P}_{\mathrm{i}}$ provindo do substrato sobre o qual a enzima promove a catálise), com posterior hidrólise do intermediário por uma molécula de água ativada pelo outro íon $\mathrm{Zn}^{2+}$ e liberação (ou transferência a outro substrato) de $\mathrm{P}_{\mathrm{i}}[36]$.

A estrutura cristalográfica da fosfatase alcalina placentária humana (PLAP) [37] permite a elucidação estrutural da TNAP, uma vez que apresentam uma homologia de 75\% [38]. A enzima apresenta três regiões distintas: uma $\alpha$-hélice N-terminal, uma região interfacial entre as subunidades denominada de "domínio coroa" e os domínios de ligação do metal (Figura 4). As regiões N-terminais de um monômero projetam-se sobre o outro. Os domínios de ligação do metal são sítios onde encontra-se um $\mathrm{Ca}^{2+}$ hepta-coordenado [38]; íon este com um papel regulatório tanto no estímulo quanto na inibição da atividade fosfohidrolítica da TNAP [39].

Apesar do ATP ser o substrato nativo da TNAP, ela catalisa a hidrólise de outros monoésteres de fosfato; dentre os quais o $p$-nitrofenil fosfato (pNFF), um substrato sintético utilizado na caracterização cinética de enzimas fosfohidrolíticas, apresentando como produto de hidrólise o $p$-nitrofenolato $\left(\mathrm{pNF}^{-}\right.$) (Figura 5). Este composto é amplamente utilizado na análise cinética de enzimas com atividade ATPásica devido à simplicidade do ensaio, uma vez que o $\mathrm{pNF}^{-}$apresenta uma banda de absorção característica em $410 \mathrm{~nm}$ (região na qual o pNFF não absorve). Já o par ADP/ATP apresentam espectros semelhantes em $260 \mathrm{~nm}$, sendo necessário um sistema enzimático de acoplamento para acompanhar o progresso da reação [40], ou alternativamente a quantificação de $\mathrm{P}_{\mathrm{i}}$ por meio de adição de reagentes cromogênicos (posteriormente a cinética). 


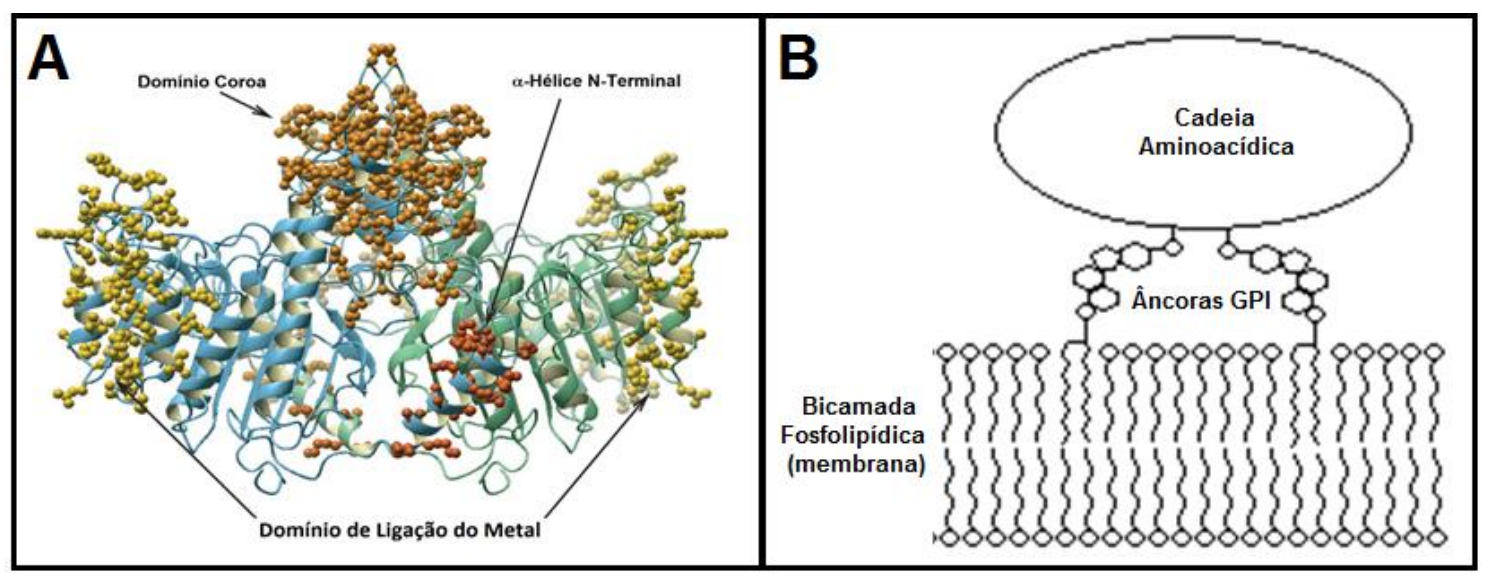

Figura 4 - Estrutura da PLAP com estruturas secundárias em representação de fitas (azul e verde) e modelos de bastões e esferas representando as cadeias laterais dos resíduos dos domínios $\mathrm{N}$-terminal (vermelho), coroa (laranja) e de ligação dos metais (amarelo) (Modificado da referência [37]) (A), diagrama esquemático da TNAP ancorada à membrana celular através de suas âncoras GPI.

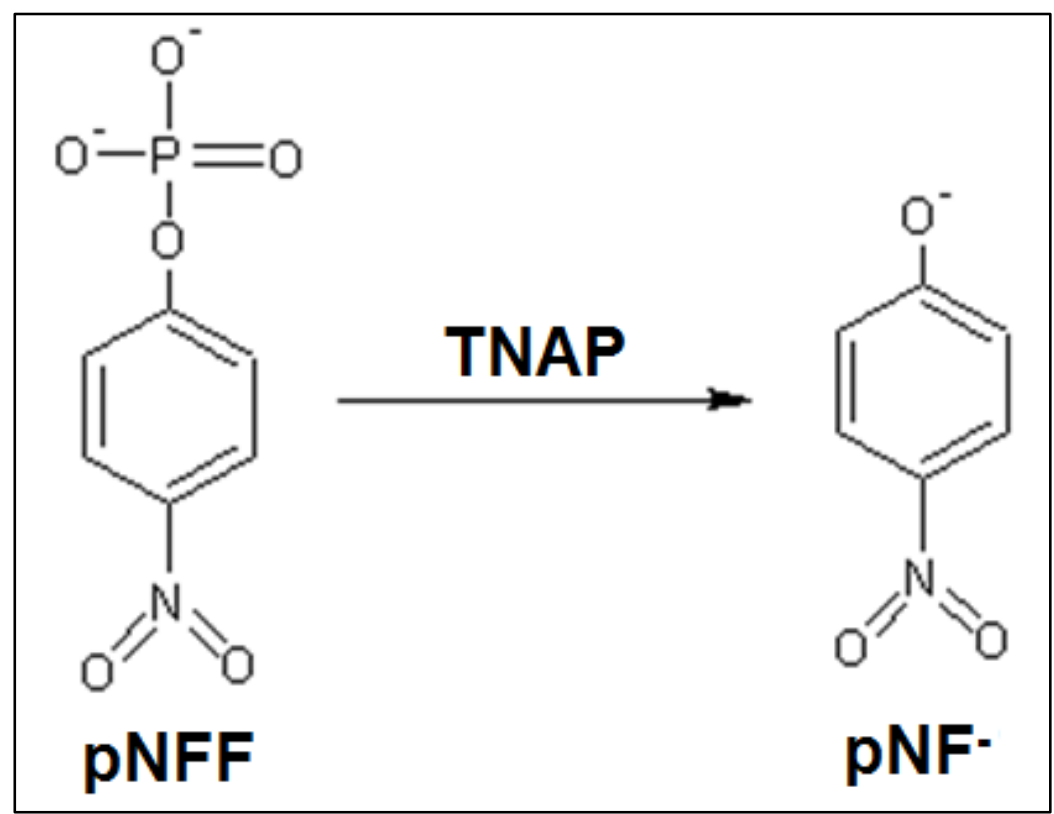

Figura 5 - Reação de hidrólise em meio básico do substrato sintético pNFF por meio da ação catalítica da TNAP, produzindo o produto cromogênico $\mathrm{pNF}^{-}$.

Enquanto algumas enzimas apresentam suas cadeias aminoacídicas atravessando integralmente a membrana celular, outras são encontradas próximas à superfície da membrana, ligadas covalentemente a grupos inseridos entre as cadeias hidrocarbônicas da membrana. A TNAP é um exemplo de uma enzima que é ancorada à membrana através de um grupo glicosilfosfatidilinositol (GPI) [41], uma "âncora" que contém um grupo glicerol esterificado com dois ácidos graxos (um acilalquilglicerol; região apolar que encontra-se embebida na bicamada fosfolipídica) e com um mio-fosfatidilinositol, 
que por sua vez está ligado a anéis piranosídicos de manoses, ligados covalentemente à região C-terminal da enzima por um grupo fosfoetanolamina (Figura 6).

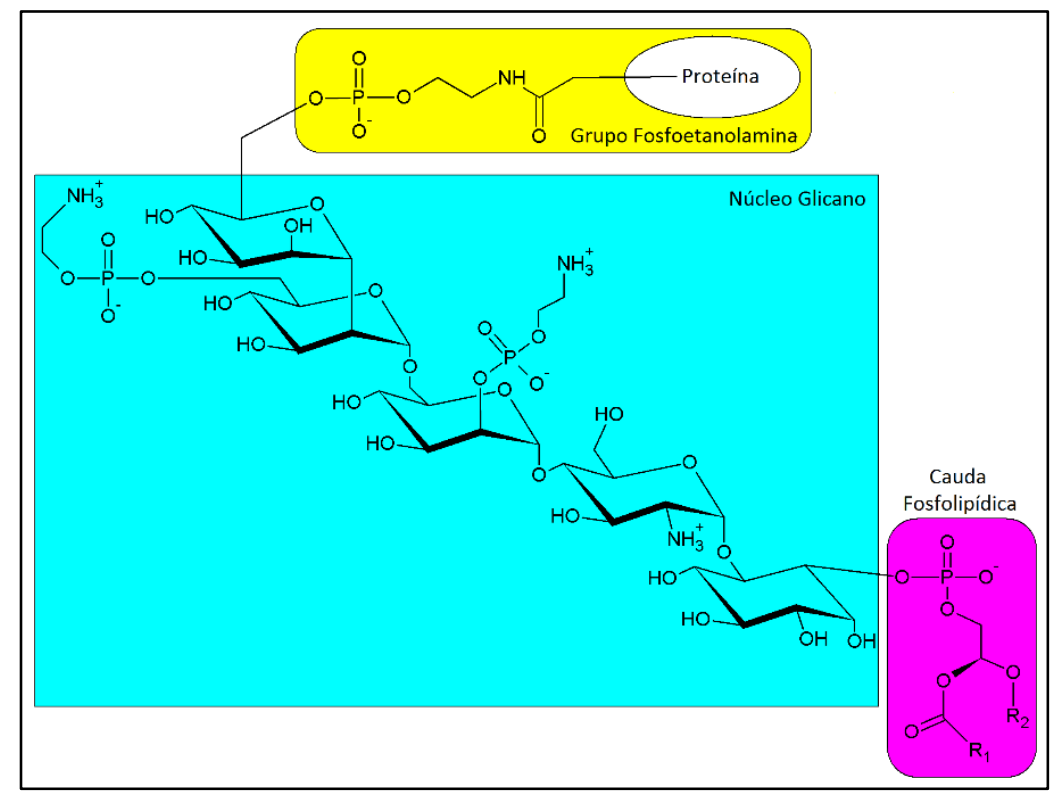

Figura 6 - Estrutura de uma âncora GPI da TNAP, destacando a cauda fosfolipídica contendo as cadeias hidrocarbônicas longas (R1 e R2) (púrpura), o núcleo glicano contendo as manoses (azul) e o grupo fosfoetanolamina (amarelo) covalentemente ligado à extremidade $\mathrm{C}$-terminal da enzima.

A remoção da TNAP da membrana celular pode ser realizada de duas maneiras: (I) por meio da solubilização com o uso de detergentes, mantendo a âncora GPI covalentemente ligada; (II) utilizando-se uma fosfolipase específica, que promove a clivagem da ligação do grupo fosfato esterificado no glicerol, levando à perda da cauda fosfolipídica [42].

O uso de detergentes na solubilização da enzima da membrana celular substitui metodologias de isolamento que podem alterar a conformação nativa da enzima, como por exemplo a obtenção de TNAP a partir de matrizes de vesícula ou condrócitos intactos utilizando-se colagenases e proteases, que podem atuar sobre a enzima-alvo de extração [43] danificando regiões não-catalíticas, podendo afetar sua função na calcificação [44]. Um detergente não-iônico comumente empregado na solubilização da TNAP é o polioxietileno 9-lauril éter (polidocanol), devido à baixa concentração necessária para estabilizar a forma solubilizada da enzima $(0,01 \%$ p/V)evitando-se interferências na concentração de substrato disponível para a reação [33].

A TNAP tem sido explorada na constituição de materiais que estimulem a osteogênese local. Estudos pilotos realizados por Piattelli et al. [45,46] mostraram que a 
presença de TNAP fisicamente adsorvida sobre peças de titânio implantadas em coelhos, promoveu uma maior formação óssea ao redor do implante.

\subsection{Materiais Bioativos}

\subsubsection{Materiais Bioativos em Implantes Ósseos}

Diversos tipos de materiais são utilizados em enxertos ou em implantes teciduais, como metálicos [47], cerâmicos [48], modificados ou não com biopolímeros e compósitos [49]. São descritos como bioativos aqueles que "provocam uma resposta biológica específica na interface do material, que resulta na formação de uma ligação entre o tecido e o material" [50]. Os primeiros fenômenos bioquímicos necessários para o sucesso de um biomaterial ocorrem na interface material/tecido hospedeiro. O contato entre um implante pouco bioativo e o tecido ósseo acarreta no crescimento de um tecido fibroso ao redor do material implantado [47], diminuindo seu contato direto com o osso, desfavorecendo sua osteointegração [51].

Como resposta biológica, espera-se uma sequência de eventos de células osteogênicas (adesão, diferenciação e proliferação) sobre a interface implante-tecido, a fim de favorecer a histogênese óssea nesta região. Uma das etapas críticas é a adesão celular, sempre precedida pela adsorção física de proteínas sobre a superfície do biomaterial [52]. Desta forma, as propriedades físico-químicas de um determinado material têm papel importante na biocompatibilidade deste com o tecido ósseo; uma vez que parâmetros superficiais, tais como a energia superficial e [53] rugosidade, textura e morfologia afetam a etapa de adesão celular (otimizada em superfícies mais hidrofílicas) [54]. Além das características superficiais (topográficas e químicas), outras propriedades que dependem da natureza do biomaterial podem favorecer a osteointegração; como a biodegradabilidade, favorável para cerâmicas reabsorvíveis de $\mathrm{Ca}_{3}\left(\mathrm{PO}_{4}\right)_{2}$, que sofrem degradação em contato com o fluido corpóreo e são substituídas por tecidos naturais [55].

Algumas metodologias são empregadas a fim de modificar física ou quimicamente a superfície de um biomaterial, mantendo as suas propriedades internas , a fim de aperfeiçoar sua biocompatibilidade [51]. O tratamento por jateamento de areia promove um aumento na rugosidade superficial do material, aumentando a proliferação celular de células osteoblastos [56]; porém, trata-se de um processo no qual não é 
possível um controle da homogeneidade e regularidade das superfícies tratadas. O recobrimento do biomaterial com o mineral constituinte da matriz óssea pode ser empregado, a fim de tornar a superfície deste quimicamente similar ao tecido onde o mesmo será implantado, sendo um pré-requisito para uma osteointegração efetiva a presença de uma camada de HAP ao redor do biomaterial [47].

A metodologia de deposição de HAP por plasma spray é uma das abordagens experimentais mais adotadas no recobrimento de implantes de substituição óssea; realizados em temperaturas acima de $10^{4} \mathrm{~K}$, resultando em coberturas porosas com espessuras na ordem de 0,2 mm de HAP [57]. Esta metodologia exige uma estabilidade do biomaterial às condições extremas de preparo; dentre os diferentes tipos de materiais utilizados, o titânio é o mais empregado em implantes ósseos.

\subsubsection{Titânio como um Biomaterial}

Ligas metálicas são amplamente utilizadas em implantes de substituição óssea, devido à sua resistência mecânica e pelo fato de serem bioinertes (suas superfícies são revestidas naturalmente por uma camada de óxido do metal, conferindo resistência à corrosão); dentre os quais as mais utilizadas são as ligas de cobalto-cromo-molibdênio (Co-Cr-Mo) [58], aço inoxidável [59] e titânio (Ti) [56].

Implantes ortodônticos e ortopédicos de ligas de $\mathrm{Ti}$ apresentam boa biocompatibilidade e estabilidade devido uma camada de $\mathrm{TiO}_{2}$ presente na superfície destes [51]. Por outro lado, a baixa reatividade que estas ligas apresentam as torna pouco bioativas, sendo necessário uma modificação superficial a fim de tornar o material mais osteointegrável. O recobrimento de superfícies de Ti por HAP provoca não só uma maior proliferação de células osteogênicas, como também aumenta o nível de expressão de fosfatase alcalina nas mesmas [60], favorecendo a formação de mineral no contato com o tecido ósseo.

Apesar de ser a metodologia mais empregada no recobrimento de HAP em superfícies, o plasma spray promove uma cobertura não homogênea deste mineral, que não incorpora agentes biologicamente ativos [61], além de produzir HAP não-hidratada, devido à alta temperatura empregada na metodologia [57]. Desta forma, outros tipos de recobrimentos de natureza híbrida (formação de HAP em um molde orgânico) são bons candidatos; dentre os quais os filmes Langmuir-Blodgett (LB) [49,61-63], obtidos a partir de monocamadas de Langmuir, formam uma camada lipídica de espessura nanométrica sobre um suporte sólido, permitindo a obtenção de um recobrimento 
homogêneo e com possibilidade de regular parâmetros do sistema, tais quais razão $\mathrm{Ca} / \mathrm{P}$ [63] e espessura do recobrimento [61,62]. Além disso, este método oferece a vantagem de constituir um sistema biomimético de membrana celular.

\subsection{Monocamadas de Langmuir}

As monocamadas de Langmuir são filmes, com espessura monomolecular, constituídos por moléculas anfifílicas insolúveis, orientadas na interface ar-líquido de uma subfase, geralmente aquosa, contida em um recipiente revestido de material inerte [64]. A compressão mecânica desta interface resulta em distintos graus de compactação. Diversos tipos de moléculas anfifílicas são capazes de formar uma monocamada em uma interface ar-água, desde polímeros [65], macromoléculas [66] e proteínas [67,68], ácidos graxos [69,70], mas principalmente os fosfolipídeos, cujos grupos polares podem apresentar carga líquida negativa [71,72] ou ainda neutra, devido à presença de grupos colina covalentemente ligados ao fosfato [73-75].

Experimentalmente, para obtenção das monocamadas, espalha-se na interface líquido-ar um volume devidamente conhecido de uma solução do lipídeo (geralmente em um solvente orgânico imiscível com a água, salvo casos nos quais tais solventes sejam incompatíveis com o lipídeo, como proteínas), seguida da posterior compressão mecânica da interface, após um intervalo de tempo que permita a volatilização do solvente utilizado na solubilização das moléculas anfifílicas. Durante esta compressão, são realizadas medidas em tempo real de tensão superficial $(\gamma)$ da subfase, que sofre um decréscimo com a presença das moléculas de lipídeos na interface ar-líquido. Este decréscimo é acompanhado em tempo-real por meio do aumento da pressão de superfície $(\pi)$ (Equação 1), que é definida como a diferença da tensão superficial da subfase pura $\left(\gamma_{0}\right)$ com aquela na presença dos surfactantes $(\gamma)$ :

$$
\pi=\gamma_{0}-\gamma
$$

\subsection{Caracterização das Monocamadas de Langmuir}

\subsubsection{Isotermas $\pi$ versus Área Molecular}


A monocamada é caracterizada graficamente por meio de sua isoterma $\pi$-A, que relaciona os valores de $\pi$ em função da área molecular (na ordem de $\AA^{2}$ por molécula de lipídeo) (Figura 7). De uma maneira geral, tais isotermas apresentam um aumento progressivo de $\pi$ (correspondendo a uma diminuição progressiva de $\gamma$ ) com a diminuição mecânica da área disponível por molécula, devido à substituição das forças intermoleculares presentes na interface ar-líquido entre as moléculas da subfase (geralmente do tipo ligação de hidrogênio, no caso de subfases aquosas) por interações do tipo dispersivas (dipolo-dipolo, forças de London), com a introdução das moléculas de lipídeos.

Os estágios de compactação da monocamada são representados em analogia ao estado tridimensional da matéria: (I) fase gasosa para o estágio mais expandido da interface (pouca ou quase nenhuma interação entre os lipídeos); (II) fase líquidoexpandido, a partir do qual há um início de orientação e interação entre as cadeias apolares; (III) fases condensadas (diminuição dos graus de liberdades internos das moléculas), com diferenças nas orientações das cadeias apolares em relação ao plano da interface (desde inclinados até totalmente verticais) (Figura 7A). As transições entre as diferentes fases são de $1^{a}$ ordem em regiões nas quais há coexistência entre elas, caracterizadas por valores constantes de $\pi$ em função da compressão. Para estágios de alta compressão é possível que a estrutura organizada da monocamada sofra um colapso, caracterizado por uma descontinuidade/queda de $\pi$ em função da diminuição de área.

A partir das isotermas $\pi$-A obtém-se parâmetros físico-químicos, que são distintos para cada lipídeo (Figura 7B). O módulo compressional $\left(\mathrm{CS}^{-1}\right)$ é obtido a partir da taxa de variação de $\pi$ em função da área molecular normalizada para cada valor de área (Equação 2) [76], indicando qual em qual estágio de compactação a monocamada encontra-se (Tabela 1) [77], além de indicar a rigidez/fluidez destas (diminuição e aumento no valor de $\mathrm{Cs}^{-1}$ indica monocamadas mais fluidas ou mais rígidas, respectivamente).

$$
C_{S}^{-1}=-A\left(\frac{d \pi}{d A}\right)_{T}
$$



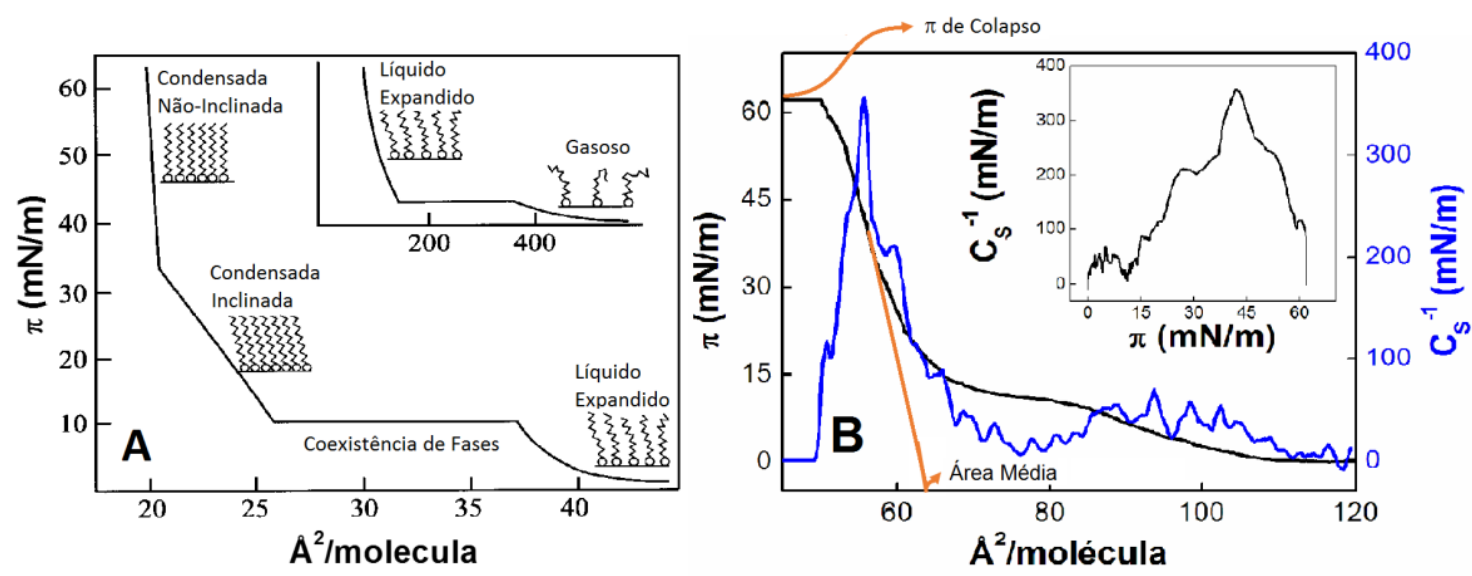

Figura 7 - Isoterma $\pi$-A de uma monocamada de Langmuir arbitrária, destacando as diferentes fases e suas transições (modificado da referência [64]) (A) e isoterma $\pi$-A e valores de $\mathrm{CS}_{\mathrm{S}}^{-1}$ de DPPC, destacando os parâmetros obtidos graficamente (B), Inserção: representação gráfica dos valores de $\mathrm{C}_{S^{-1}}$ em função de $\pi$ ).

Tabela 1 - Valores de $\mathrm{CS}_{\mathrm{S}}{ }^{-1}$ para as diferentes fases de uma monocamada

\begin{tabular}{lc}
\hline Fase da Monocamada & $\begin{array}{c}\mathrm{Cs}^{-1} \\
\left(\mathrm{mN} \mathrm{m}^{-1}\right)\end{array}$ \\
\hline Superfície Limpa & 0 \\
Líquido Expandido & $12.5-50$ \\
Condensado Inclinado & $100-250$ \\
Condensado Não-Inclinado & $1-2.10^{3}$ \\
\hline
\end{tabular}

A área média é a área molecular a partir da qual obtém-se fases condensadas para a monocamada. Este valor pode ser obtido graficamente a partir da tangente da região linear de $\pi$, a partir da qual a fase condensada é formada, até um valor nulo de $\pi$ (Figura 7B), sendo um parâmetro de comparação entre diferentes lipídeos para verificar modificações na estrutura ou estágio de compressão de uma mesma monocamada quando exposta a diferentes condições.

\subsubsection{Caracterização das Monocamadas de Langmuir por técnicas microscópicas}

Além das isotermas $\pi$-A, outras abordagens experimentais permitem a caracterização das monocamadas de fosfolipídeos. A adição de um lipídeo contendo um grupo fluorescente (resultando em menos de $2 \%$ da quantidade total em mol) permite 
observar, utilizando-se micrografias por microscopia de fluorescência, a formação de microdomínios; por meio da partição desta molécula anfifílica nas diferentes fases da monocamada [78]. Fases mais condensadas expulsam as moléculas anfifílicas contendo o grupo fluorescente, apresentando-se escuras nas micrografias, enquanto que as regiões fluorescentes correspondem às fases mais expandidas. Tal metodologia permite estudar a formação e morfologia dos domínios contendo os lipídeos em condições diversas de $\mathrm{pH}$, temperatura, força iônica [79] ou até mesmo na presença de aditivos como esteróis [80-82] e proteínas [83,84]. Os lipídeos estão em uma orientação na interface que provoca um alinhamento dos dipolos, responsável por repulsão intereletrônica entre os domínios [71,79,85], justificando o tamanho finito destes [79].

Apesar de sua versatilidade na análise da estruturação de monocamadas de Langmuir, a técnica de microscopia de fluorescência exige a adição de um lipídeo contendo um grupo fluorescente quimicamente ligado (ou até mesmo a adição de uma molécula com atividade fluorescente), exigindo, portanto, a introdução de uma "impureza" na interface ar-líquido; algo que pode modificar significativamente a estruturação da monocamada. Desta forma, metodologias que não necessitem da introdução de novas moléculas ao sistema apresentam a vantagem de caracterizar a organização autêntica da monocamada sobre a subfase. Neste contexto, a microscopia no ângulo de Brewster (BAM), uma técnica na que não requer a adição de aditivos para obtenção de micrografias, utilizando diferenças de contraste entre regiões com e sem lipídeos [86] (Figura 8).

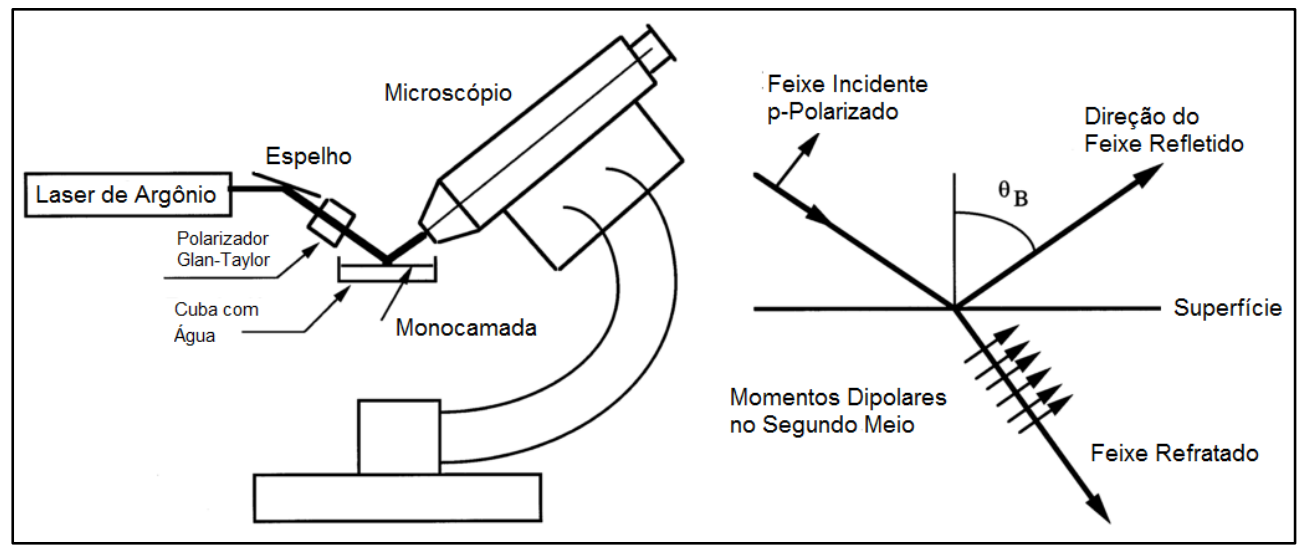

Figura 8 - Montagem experimental de um microscópio acoplado a uma cuba de Langmuir, com um diagrama esquemático da incidência da radiação eletromagnética ppolarizada, incidida em um determinado ângulo $\left(\theta_{\mathrm{B}}\right)$ com a normal à interface de Fresnel (reflexão nula), denominado ângulo de Brewster (Modificado da referência [86]). 
O princípio desta técnica é baseado na refletividade nula em um determinado ângulo de incidência (determinado de ângulo de Brewster, $\theta_{\mathrm{B}}$ ) de uma radiação eletromagnética p-polarizada (cuja polarização do campo elétrico ocorre no mesmo plano de incidência da radiação) sobre uma interface de Fresnel; definição esta para uma interface livre de rugosidade cujo índice de refração da fase inferior muda abruptamente com relação à fase superior. A presença de lipídeos na interface ar-líquido promove reflexão da radiação incidente, produzindo a imagem de microscopia (sendo as regiões claras correspondentes à presença dos lipídeos em fases mais condensadas), permitindo a observação de domínios em diferentes fases de maneira análoga à análise por microscopia de fluorescência. A principal diferença nas micrografias de fluorescência com aquelas obtidas por BAM está no fato de que as regiões que contêm os lipídeos em fases mais condensadas na interface aparecem com contraste escuro e claro, respectivamente $[87,88]$ (Figura 9).
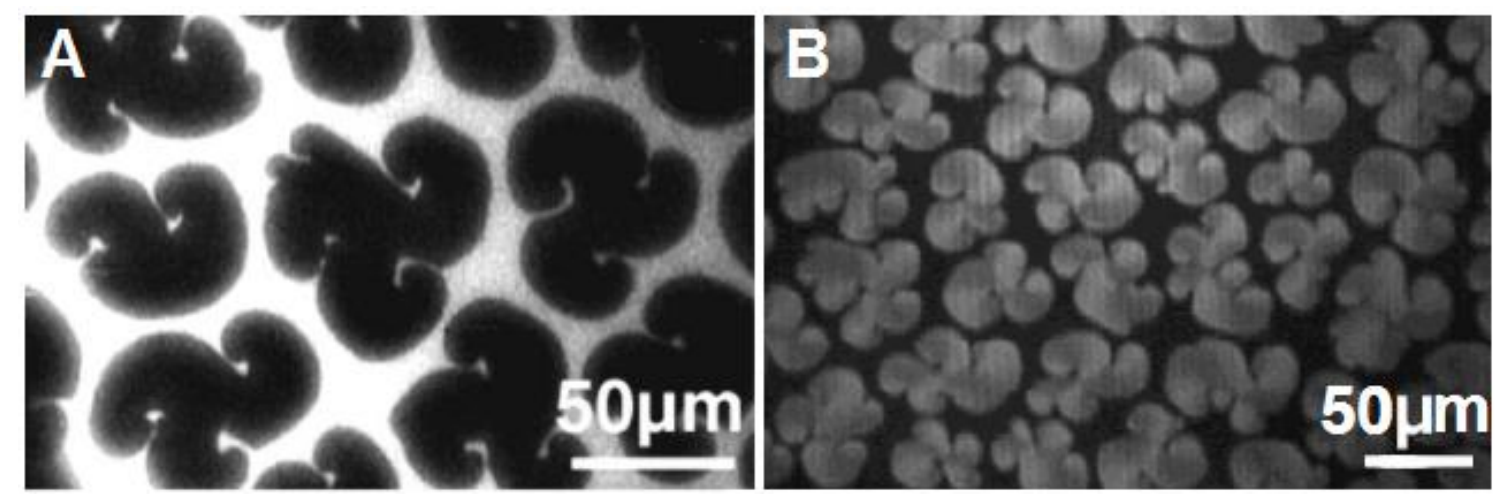

Figura 9 - Imagens de micrografias de monocamadas de DPPC obtidas por: microscopia de fluorescência em subfase de $\mathrm{NaCl} 0,2 \mathrm{~mol} \mathrm{~L}^{-1} \mathrm{em} \pi=16,9 \mathrm{mN} \mathrm{m}^{-1}$ (A), microscopia BAM em subfase de tampão fosfato $75 \mathrm{mmol} \mathrm{L}^{-1}(\mathrm{pH} \mathrm{7,4)} \mathrm{em} \pi=10 \mathrm{mN}$ $\mathrm{m}^{-1}$ (B) (Modificados das referências [87,88]).

\subsubsection{Pressão Superficial de Exclusão}

Além do estudo de aditivos co-espalhados com os lipídeos na interface ar-líquido, é possível também um estudo da inserção de moléculas com atividade superficial (com solubilidades parciais ou insolúveis na subfase) nas monocamadas pré-formadas em um determinado valor de $\pi$, o que provocará um aumento na pressão de superfície (até obtenção de um valor constante) em função do tempo. A aquisição das variações da pressão de superfície $(\Delta \pi)$, induzidas pela inserção dos aditivos na monocamada em função de diferentes pressões iniciais $\left(\pi_{\mathrm{i}}\right)$ inicialmente estabelecidas pela presença dos 
surfactantes que constituem a monocamada) permite a obtenção de $\pi_{\mathrm{i}}$ a partir da qual o valor de $\Delta \pi$ será nulo; parâmetro conhecido como pressão superficial de exclusão $\left(\pi_{\mathrm{exc}}\right)$, que estabelece o valor de $\pi_{\mathrm{i}}$ a partir do qual a penetração do aditivo na monocamada é dificultada.

A determinação da $\pi_{\text {exc }}$ pode ser feita espalhando na interface, primeiramente, o lipídeo que constituirá a monocamada, até atingir o valor desejado de $\pi_{\mathrm{i}}$ (seja por compressão mecânica da interface ou ainda por simples adição progressiva de porções de surfactante). Posteriormente injeta-se o aditivo no interior da subfase e registra-se o valor de $\pi$ em função do tempo até atingir um valor constante. Deste valor de $\pi$ constante é subtraído $\pi_{\mathrm{i}}(\Delta \pi)$, expressando graficamente estes valores em função de $\pi_{\mathrm{i}}$, determinando-se $\pi_{\text {exc }}$ como o intercepto da reta com a abscissa do gráfico. Tal abordagem experimental permite a caracterização da interação de aditivos como, por exemplo, lipídeos [72] e proteínas [89-91].

\subsection{Sistemas Bioinspirados}

\subsubsection{Sistemas Miméticos de Membrana Celular}

A membrana celular é responsável pela compartimentalização de células, formada por uma bicamada fosfolipídica com orientação das moléculas determinada pelo efeito

hidrofóbico [92]; na qual as cadeias hidrocarbônicas mantêm contato umas com as outras e as cabeças polares são orientadas para as faces externa e interna da célula (em contato com um meio aquoso, altamente polar) (Figura 10). A constituição lipídica de uma membrana não é homogênea, apresentando majoritariamente lipídeos carregados negativamente na face citosólica (contendo grupos fosfatidilserina) e zwitteriônicos na face externa (contendo grupos fosfatidilcolina) [93]. 


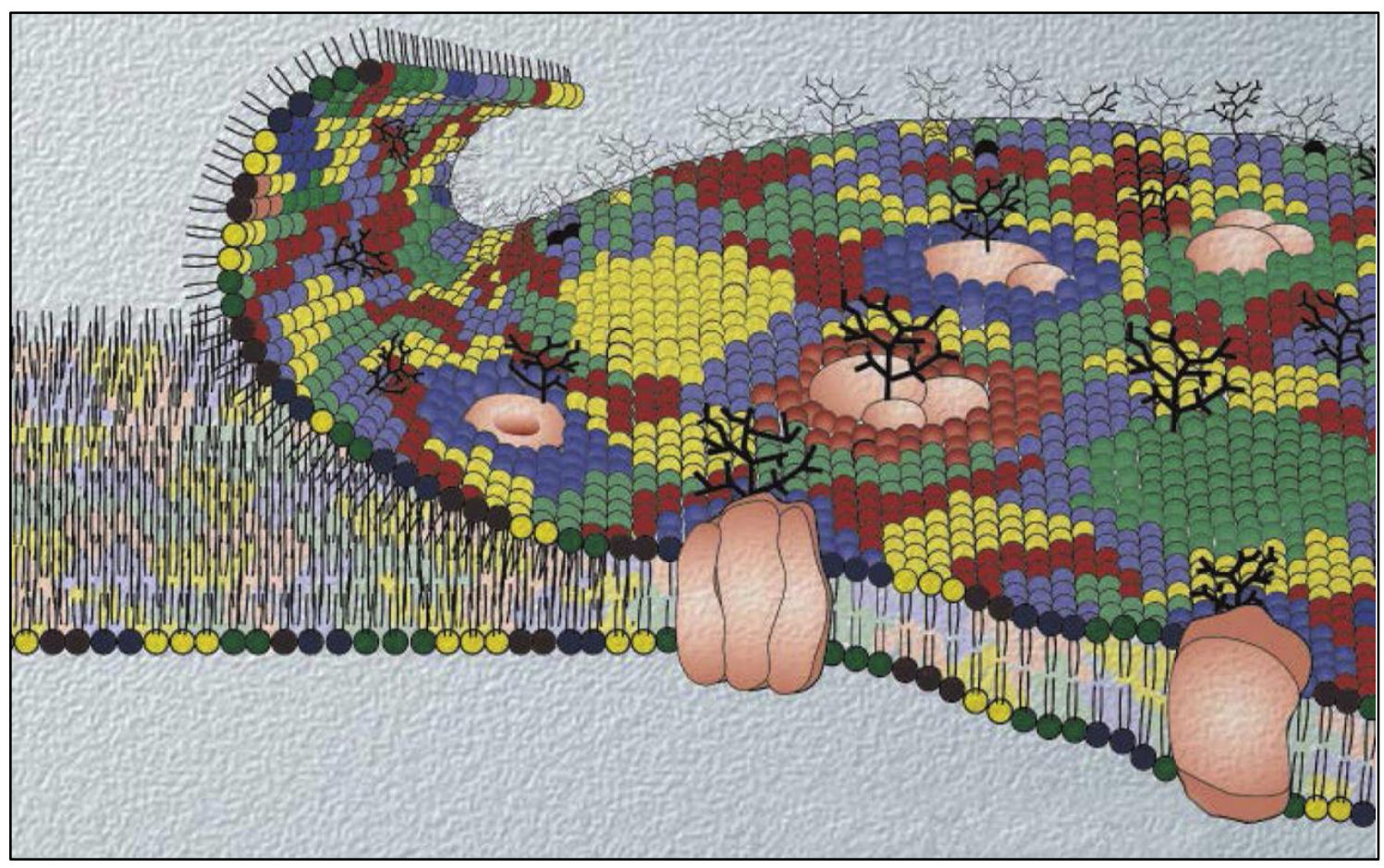

Figura 10 - Representação da bicamada lipídica de uma membrana celular, contendo proteínas integrais (rosa) e regiões glicosiladas (preto) (extraído da referência [92]).

Dentre os diferentes sistemas miméticos de membrana celular, os lipossomos são amplamente utilizados em diversos estudos biofísicos ou bioquímicos; desde a avaliação termotrópica dos lipídeos (e suas misturas) constituintes destas vesículas [94], até a reconstituição de proteínas de membranas nos proteolipossomos [95,96].

Em analogia às vesículas de matriz secretadas pelas células osteogênicas, a TNAP imobilizada em lipossomos constitui um sistema modelo que permite o estudo de sua atividade fosfohidrolítica e do processo de nucleação da mineralização [32,97,98]. Para tal, emprega-se uma solução que contem concentrações fisiológicas de eletrólitos (dentre os quais íons $\mathrm{Ca}^{2+}$ ) e substratos fosforilados (ATP), denominada de fluido de cartilagem sintética (Synthetic Cartilage Lymph - SCL) [99]. A adição de proteolipossomos (contendo TNAP ancorada) à solução SCL promove um aumento na concentração de fosfato inorgânico $\left(\mathrm{P}_{\mathrm{i}}\right)$ tempo dependente, devido à ação fosfohidrolítica desta enzima sobre o ATP; responsável pela supersaturação local de íons $\mathrm{Ca}^{2+}$ e $\mathrm{P}_{\mathrm{i}}$, propiciando a formação de fosfatos de cálcio, que nucleiam ou crescem sobre centros nucleadores de fosfato de cálcio amorfo (ACP). Estes nucleadores são combinados com fosfatidilserina - PS - que formam um complexo lipídeo-fosfatocálcio PS-CPLX [98]. 
Apesar de não apresentar uma estrutura de uma bicamada, as monocamadas de Langmuir permitem uma mimetização em analogia a uma meia membrana [100]; um sistema que apresenta como principais vantagens: (I) controle preciso de propriedades termodinâmicas ( $\pi$ e temperatura); (II) permitem alcançar diversos estágios de empacotamento lateral das moléculas anfifílicas e (III) possibilitam um estudo das interações dos constituintes da monocamada com a subfase ou entre si. Apesar de ser possível um controle na escolha do valor de $\pi$ no qual a monocamada será confeccionada, valores próximos de $30 \mathrm{mN} \mathrm{m}^{-1}$ são escolhidos a fim de mimetizar a membrana celular, utilizando a monocamada como um sistema modelo de membrana [100]; uma vez que há um consenso na literatura acerca deste valor de $\pi$ ser equivalente ao nível de compressão da bicamada fosfolipídica de membranas celulares [101].

Assim como na membrana celular, as proteínas podem ser inseridas nas monocamadas de Langmuir, para estudos de interação destas com os lipídeos [67,102105]. Desta forma, as enzimas de membrana celular podem ser inseridas neste sistema mimético; em especial as enzimas que contêm grupos hidrofóbicos que proporcionam certa atividade superficial à cadeia polipeptídica. A TNAP já fora amplamente aplicada e estudada utilizando-se monocamadas de Langmuir [68,83,84,90,106-109], por apresentar a âncora de GPI essencial para sua atividade superficial [109,110]; destacando sua atividade fosfohidrolítica modulada pela $\pi$ da monocamada fosfolipídica [84]. As diferenças nas metodologias de inserção da enzima na monocamada [83] e ainda a avaliação de grupos funcionais e orientação das cadeias polipeptídicas na interface ar-líquido pode ser avaliada por espectroscopia de infravermelho in situ [68].

Os filmes Langmuir-Blodgett (LB) confeccionados a partir das monocamadas de Langmuir são sistemas vantajosos na mimetização da membrana celular, uma vez que durante sua preparação é possível o controle de parâmetros como a espessura do filme, temperatura de transferência [111] e polaridade final da superfície (hidrofílica ou hidrofóbica se a última camada apresentar a cabeça polar ou a cauda apolar do lipídeo voltada para o ar, respectivamente) [112]. Apesar do valor de $\pi=30 \mathrm{mN} \mathrm{m}^{-1}$ ser escolhido para utilizar as monocamadas como sistema mimético de membrana celular, a confecção de filmes LB a partir destas não necessariamente deve ser feita neste valor de $\pi$, uma vez que em determinadas condições as condições ótimas de deposição e transferência ocorrem para outros valores de $\pi$, como demonstrado para a construção de filmes LB em pressões acima de $\pi=35-45 \mathrm{mN} \mathrm{m}^{-1}[112,113]$. 
Tais filmes são bons candidatos na imobilização de enzimas, anticorpos ou ligantes específicos; tornando-os funcionalizados para bioespecificidade [114]. A imobilização de TNAP em suportes modificados com filmes LB pode ser feita através da adsorção física da mesma [106], ou ainda através da co-adsorção da enzima com lipídeos durante a confecção do filme LB [108]; permitindo a avaliação de sua atividade fosfohidrolítica antes e após sua imobilização no filme.

\subsubsection{Modificação Superficial de Ti com Filmes LB Híbridos}

A modificação superficial de suportes de titânio com os filmes LB para posterior formação e crescimento de minerais de fosfato de cálcio (mais especificamente de HAP) é uma via alternativa para o aumento de bioatividade da superfície de Ti de próteses ósseas [61-63], possivelmente proporcionando uma melhor osteointegração destas no tecido ósseo. Os filmes LB são construídos a partir de subfases contendo íons $\mathrm{Ca}^{2+} \mathrm{e}$, escolhendo um lipídeo que contenha grupos com afinidade por estes íons (como grupos fosfato [61,62] ou grupos carboxilato [63]), promove-se a co-adsorção desses íons no molde propiciado pelo filme LB.

Após a modificação superficial é realizada uma exposição do suporte modificado a uma condição propícia para a nucleação e crescimento de uma fase mineral. Na préformação de carbonatos de cálcio, a exposição a uma atmosfera saturada de $\mathrm{CO}_{2(\mathrm{~g})}$ induz a precipitação de uma fase de $\mathrm{CaCO}_{3}$ no filme [62]; para a pré-formação de uma fase de fosfato de cálcio, realiza-se ciclos de imersão em tampão fosfato seguido de imersão em solução de $\mathrm{CaCl}_{2}$, induzindo em uma supersaturação de íons $\mathrm{Ca}^{2+} \mathrm{e} \mathrm{PO}_{4}{ }^{3-}$ no filme $\mathrm{LB}$ [61].

A deposição homogênea de HAP em filmes LB pode ser realizada in vitro ao expor as superfícies modificadas em uma solução que mimetiza a concentração iônica do plasma sanguíneo, conhecida como solução fluido corpóreo simulado (Simulated Body Fluid - SBF) [115] (Figura 11). 


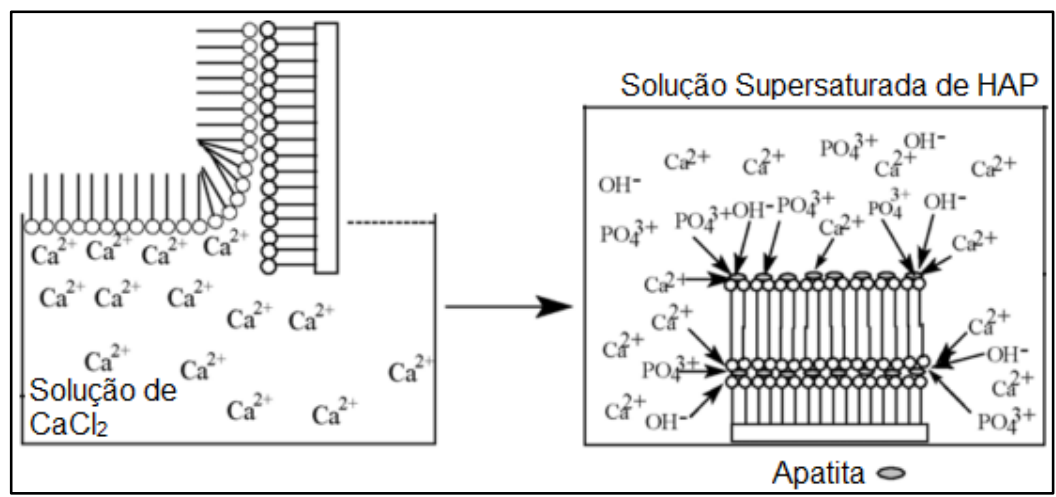

Figura 11 - Diagrama esquemático da formação de um filme LB sobre um suporte sólido em subfase de $\mathrm{CaCl}_{2}$ seguida da exposição deste em solução SBF (Modificado da referência [63]).

A nucleação e o crescimento de HAP orientada pelo filme LB na superfície do suporte sólido pode ser confirmada por métodos espectroscópicos, confirmando a fase mineral por difração de Raios X (DRX).

No trabalho de Piatteli et al. [116], a fosfatase alcalina foi imobilizada em superfícies de Ti por processo de adsorção simples. Os resultados obtidos mostram que as amostras preparadas em presença da enzima estimularam o crescimento ósseo em torno da superfície metálica de maneira mais eficiente do que o controle na ausência da enzima. A revisão publicada por Puleo et al. [117], explicita a importância do processo de ligação utilizado para imobilização superficial de enzimas na indução de respostas celulares especificas. Ainda, o uso de substâncias que estimulem a formação óssea é de grande valia na área de implantes de substituição óssea, pois diminui o tempo de recuperação, o índice de rejeição e desconforto dos pacientes.

Uma vez conhecido que a atividade fosfohidrolítica da TNAP é mantida na sua imobilização em filmes LB, essencial na formação de HAP na matriz extracelular de células osteogênicas, foi avaliado neste trabalho a capacidade desta enzima imobilizada em superfícies de Ti em induzir uma formação de mineral através da supersaturação de íons $\mathrm{P}_{\mathrm{i}}$ e $\mathrm{Ca}^{2+}$. Cabe destacar que até o momento atual nenhuma abordagem experimental aliou o estudo da imobilização de TNAP em filmes LB com agentes osteoindutores.

\subsection{Filmes Langmuir-Blodgett}


Os filmes LB são construídos a partir da transferência de uma ou mais monocamadas de Langmuir para um suporte sólido [118], por meio da imersão ou emersão do suporte através da interface: ao atravessar a interface ar-líquido, contendo a monocamada em uma determinado valor de $\pi$ (geralmente em estados condensados), uma camada é transferida à superfície do suporte. Para um suporte com superfície hidrofílica, inicia-se este processo a partir da emersão do mesmo, para que seu contato seja com as cabeças polares dos lipídeos (em contato com a subfase). Diferentes tipos de filmes LB podem ser confeccionados, dependendo das etapas de imersão/emersão em cada transferência (Figura 12). Os filmes do tipo $\mathrm{Y}$ são os mais comumente encontrados, uma vez que apresentam um arranjo no qual os grupos de mesma afinidade estão em contato entre si (interações do tipo cabeça-cabeça e cauda-cauda), conferindo maior estabilidade ao filme formado.

O aparato experimental para a confecção tanto de filmes LB quanto de monocamadas é denominado cuba de Langmuir (Figura 13), um recipiente revestido de material inerte e livre de materiais com atividade superficial (geralmente teflon), contendo uma ou mais barreiras móveis (responsáveis pela compressão mecânica da interface), acoplada a um tensiômetro responsável por medidas de $\gamma$, geralmente baseadas na capilaridade da subfase; mais comumente caracterizado por uma placa de Wilhelmy hidrofílica interceptando a interface. Para a sustentação e ciclos de imersão/emersão do suporte sólido sobre o qual será depositado o filme LB, um sistema dip-coater também é acoplado à cuba, contendo um poço que permite o movimento vertical do suporte no interior da mesma.
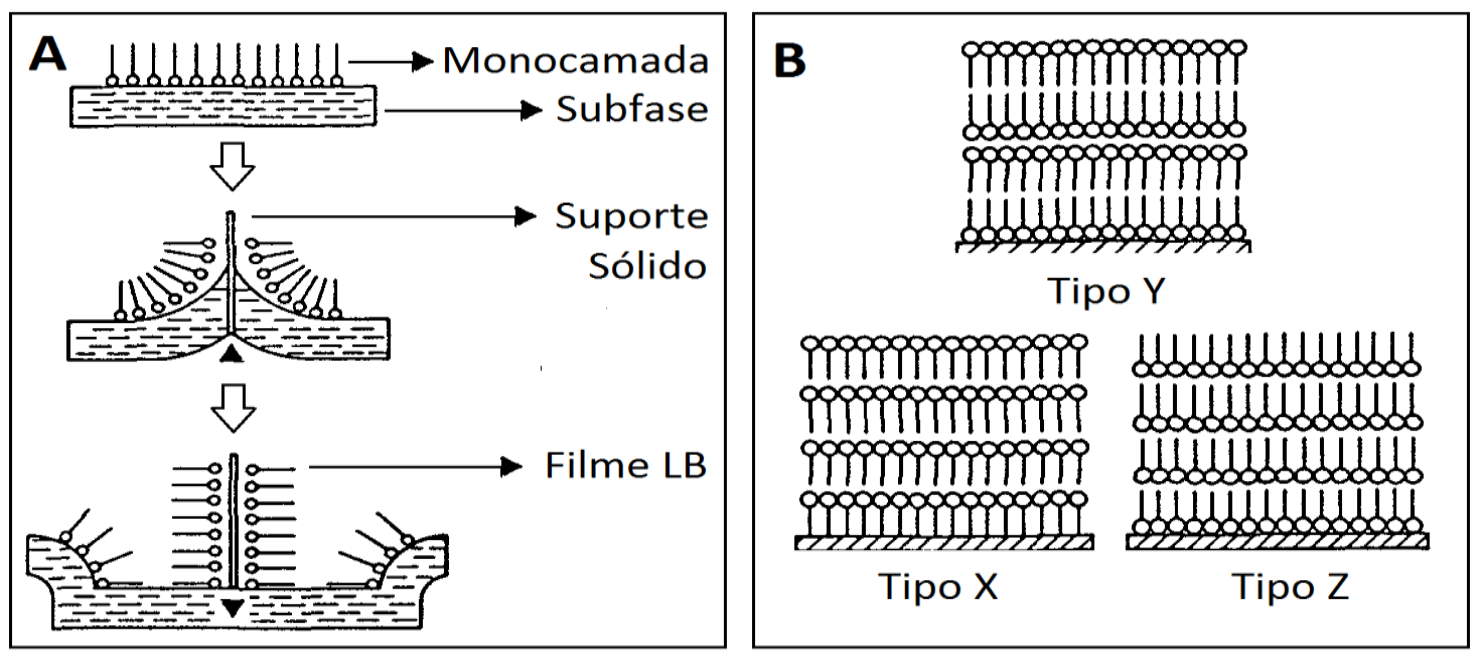

Figura 12 - Diagrama esquemático da deposição de um filme LB a partir da emersão sobre um suporte sólido (A) e os diferentes tipos de filme LB encontrados (B) (modificado da referência [118]). 


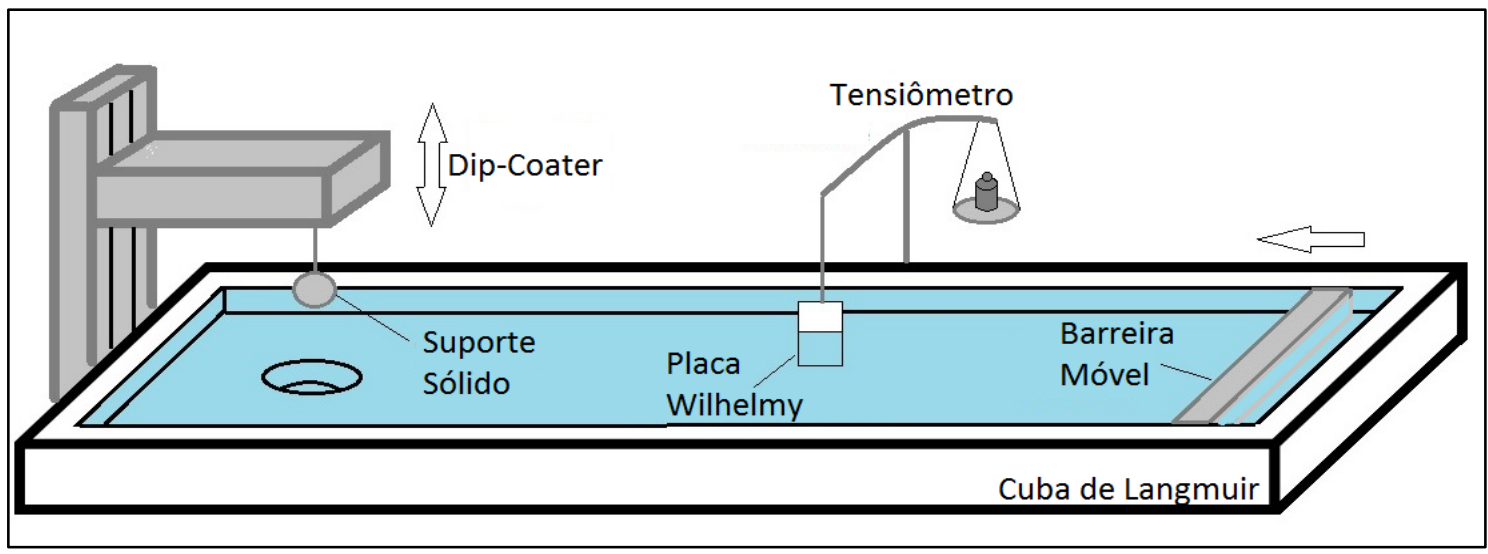

Figura 13 - Esquema de uma cuba de Langmuir acoplada a um tensiômetro da placa de Wilhelmy e a um sistema dip-coater para a confecção de filmes LB.

\subsection{Caracterização dos Filmes Langmuir-Blodgett}

\subsubsection{Razão de Transferência}

Durante a confecção de um filme LB por meio da transferência dos lipídeos para o suporte sólido, há uma diminuição na quantidade destes na interface, levando a uma diminuição de $\pi$; sendo necessário, portanto, uma compressão da monocamada [112] a fim de manter o valor de $\pi$ constante durante o movimento vertical do suporte sólido [119]. A partir desta compensação de área (provocada pela barreira móvel) é possível determinar a eficiência da transferência (Equação 3), através do quociente entre a área do suporte sólido $\left(\Delta \mathrm{A}_{\text {sup. }}\right)$ e a área da interface comprimida durante a deposição ( $\left.\Delta \mathrm{A}_{\text {interf. }}\right)$; razão esta denominada de razão de transferência $\left(\mathrm{R}_{\text {transf. }}\right)[120]$.:

$$
R_{\text {transf. }}=\frac{\Delta A_{\text {sup. }}}{\Delta A_{\text {interf }}}
$$

Transferências homogêneas apresentam valores de $\mathrm{R}_{\text {transf. próximos da unidade }}$ (representando equivalência entre as áreas de compensação e do suporte sólido), enquanto que valores acima e abaixo da unidade indicam transferências ineficientes ou sob regimes de multicamadas, respectivamente.

\subsubsection{Microgravimetria dos filmes LB}


A microgravimetria dos filmes LB é realizada utilizando-se a técnica da microbalança a cristal de quartzo (QCM), que consiste na deposição dos filmes LB sobre um suporte de quartzo (área ativa A, densidade $\rho_{\mathrm{q}}$ e módulo de cisalhamento $\mu$ de valores $0,662 \mathrm{~cm}^{2}, 2,64 \mathrm{~g} \mathrm{~cm}^{-3}$ e 2,95 x $10^{11} \mathrm{dyn} \mathrm{cm}^{-2}$, respectivamente) revestido com ouro [121], realizando medidas de frequências oscilação do cristal antes (com frequência de oscilação inicial $\left.f_{0}\right)$ e após a transferência do filme $(\Delta f)$ e obtendo a massa do mesmo $(\Delta \mathrm{m})$ através da equação de Sauerbrey [122]:

$$
\Delta m=-\frac{\Delta f \cdot A \cdot\left(\mu \cdot \rho_{q}\right)^{\frac{1}{2}}}{2 \cdot f_{0}^{2}}\left(\frac{H z \cdot c m^{2} \cdot\left(d y n \cdot g \cdot c m^{-5}\right)^{\frac{1}{2}}}{H z^{2}}\right)
$$

\subsubsection{Micrografias dos Filmes LB}

Além da quantificação de massa transferida durante a confecção do filme LB, a topografia da superfície modificada pelo filme pode ser caracterizada por técnicas microscópicas, dentre as quais a microscopia de força atômica (AFM), devido à sua resolução de ordem nanométrica. A análise de micrografias de AFM permite obter parâmetros como rugosidade média e área superficial, que relacionam-se às propriedades de molhabilidade e hidrofilicidade da superfície modificada [61]. Pode-se ainda determinar a espessura de cada camada/bicamada [123] e parâmetros relacionados a propriedades nanomecânicas do filme LB [112]. Desta forma, foi possível verificar as diferenças topográficas de um mesmo tipo de filme formado sobre uma superfície hidrofílica ou sobre uma superfície hidrofóbica, definindo qual a condição ótima de deposição [124]. Esta técnica também foi utilizada na verificação do efeito positivo da força iônica na formação de bicamadas sobre um suporte sólido [123].

A microscopia eletrônica de varredura (MEV) permite a caracterização morfológica superficial de suportes sólidos modificados com os filmes LB, em situações nas quais os filmes funcionam como moldes para modificações químicas superficiais. Suportes modificados com filmes LB foram imersos em soluções supersaturadas de íons que nuclearam e cresceram filmes minerais sobre a superfície [61,62] e foram caracterizados por MEV. A presença dos íons responsáveis pela nucleação no filme LB promove uma situação favorável para a formação do mineral na superfície do suporte sólido. 


\subsubsection{Caracterização Espectroscópica dos Filmes LB}

A composição de filmes LB pode ser realizada a partir de medidas espectroscópicas, dentre as quais a espectrofotometria ultravioleta-visível (UV-Vis, para um suporte sólido transparente à radiação incidente, como placas de quartzo) permite verificar a co-adsorção de grupos ou moléculas cromóforas. São necessárias poucas monocamadas transferidas para o suporte sólido (de 1 a 10) a fim de obter valores significativos de absorção por espectrofotometria UV-Vis tradicional [125,126].

Espectroscopia de infravermelho com transformada de Fourier (FTIR) utilizandose um acessório de reflexão total atenuada (ATR) pode ser utilizada para caracterizar grupos funcionais presentes em filmes LB [127]. Nesta técnica, a onda eletromagnética (na região do infravermelho) torna-se uma onda evanescente e sofre reflexão total interna em um cristal (geralmente de germânio) com índice de refração menor que o da amostra. Análises qualitativas da constituição do filme LB, a partir das frequências das bandas de absorção (correspondendo a diferentes grupos funcionais) podem ser realizadas. Ainda, análises quantitativas são possíveis utilizando-se intensidades absolutas das bandas de absorção e uma banda de referência interna, linearmente dependentes do número de monocamadas transferidas [111,128,129].

\subsubsection{Energia Livre Superficial das Superfícies Modificadas com Filmes LB}

A molhabilidade de uma determinada superfície pode ser definida em função do ângulo de contato $(\theta)$ que uma gota d'água séssil forma com a interface sólido-ar (Figura 14). O espalhamento desta gota (em um estado estacionário) ocorrerá dependendo de um equilíbrio de forças interfaciais, sendo representados pela tensão superficial do líquido $\left(\gamma_{\mathrm{LV}}\right)$ e da energia superficial do sólido $\left(\gamma_{\mathrm{SV}}\right)$; parâmetros relacionados na equação de Young-Dupré (Equação 5) [130].

$$
\gamma_{S V}=\gamma_{S L}+\gamma_{L V} \cos \theta
$$




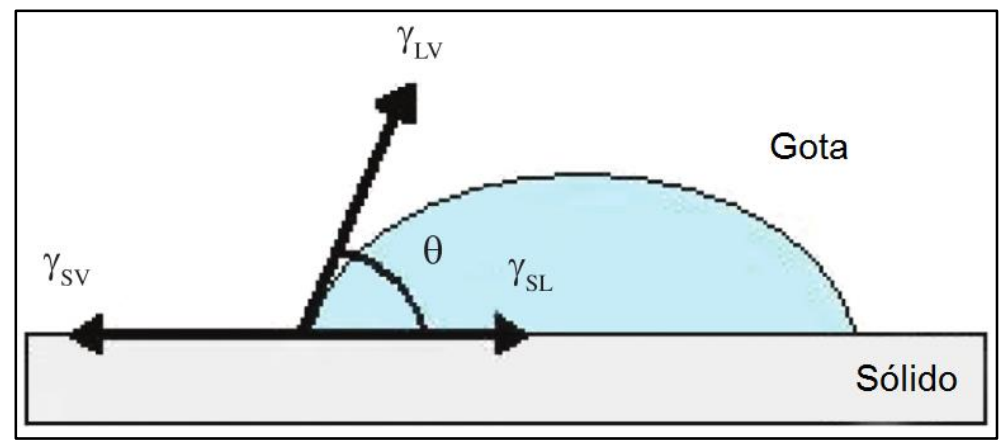

Figura 14 - Diagrama esquemático das forças entre as interfaces sólido-ar $\left(\gamma_{\mathrm{SV}}\right)$, sólidolíquido $\left(\gamma_{S L}\right)$ e líquido-ar $\left(\gamma_{\mathrm{LV}}\right)$, responsáveis pelo ângulo de contato da gota do líquido sobre a superfície sólida (Modificado da referência [130]).

Considera-se que a superfície será hidrofílica para ângulos $\theta<90^{\circ}$ (quanto maior o valor de $\cos \theta$, mais hidrofílica a superfície, para $\gamma_{\mathrm{SV}}>\gamma_{\mathrm{SL}}$ ), ou hidrofóbica para $90^{\circ}<$ $\theta<150^{\circ}$ (quanto mais negativo o valor de $\cos \mathrm{q}$, mais hidrofóbica será a superfície, para $\gamma_{S L}>\gamma_{S V}$ ). Considera-se ainda que $\gamma_{L V}$ (assim como $\gamma_{S V}$ ) é composta pela soma de duas parcelas, uma dispersiva $\left(\gamma^{\mathrm{d}}\right)$ e outra polar $\left(\gamma^{\mathrm{p}}\right)$.

A partir da Equação 5, foi derivada uma relação entre a tensão superficial do líquido $\left(\gamma_{L V}-\right.$ e suas componentes $\gamma_{L V}{ }^{P}$ e $\left.\gamma_{L V}{ }^{d}\right)$, as componentes polares e dispersivas da energia livre de superfície de uma superfície sólida $\left(\gamma_{S V}{ }^{\mathrm{P}}\right.$ e $\gamma_{S V}{ }^{\mathrm{d}}$, respectivamente) e o valor de $\theta$ para uma gota séssil de um líquido sobre tal superfície, conhecida como Equação de Owens-Wendt-Kaeble (Equação 6) [131]. Desta forma, a obtenção de $\gamma_{S V}$ é feita ajustando os valores de $\theta$ obtidos empiricamente (por meio de imagens do perfil da gota séssil sobre a superfície), na Equação 6 para diferentes líquidos puros (cujos valores $\gamma_{L V}{ }^{P}$ e $\gamma_{L V}{ }^{d}$ são conhecidos e tabelados).

$$
\gamma_{L V}(1+\cos \theta)=2\left({\gamma_{L V}}^{d} \cdot{\gamma_{S V}}^{d}\right)^{\frac{1}{2}}+2\left(\gamma_{L V}^{p} \cdot \gamma_{S V}^{p}\right)^{\frac{1}{2}}
$$

\subsection{Análise do Formato da Gota Eixo-Simétrico}

Existem diversas abordagens experimentais para a quantificação da $\gamma$ de um sistema líquido, dentre as quais a metodologia da análise do formato da gota eixosimétrica (ADSA). Esta técnica é baseada na extração do perfil de uma gota pendente, a partir do qual é criado um sistema de coordenadas e os valores de $\gamma$ são obtidos por 
meio da resolução da equação de Young-Laplace para interfaces curvas com base nas ordenadas arbitrárias [132,133].

Esta metodologia é vantajosa uma vez que não faz uso de um aparato experimental que intercepta a interface, como os métodos baseados na capilaridade; além do volume reduzido da gota pendente (ordem de microlitros) ser um microambiente com alta razão área volume (cerca de 10x maior que em uma cuba de Langmuir), tornando as propriedades interfaciais mais importantes.

Esta metodologia permite ainda uma análise simultânea de tensiometria com propriedades espectroscópicas, por meio do acoplamento da metodologia ADSA com a espectrofotometria UV-Vis por reflectância difusa (DRUV), conforme metodologia desenvolvida neste projeto [134]. Utilizando-se esta metodologia é possível obter, simultaneamente em tempo-real, valores de $\gamma$ e espectros UV-Vis de moléculas cromogênicas no interior da gota pendente. 


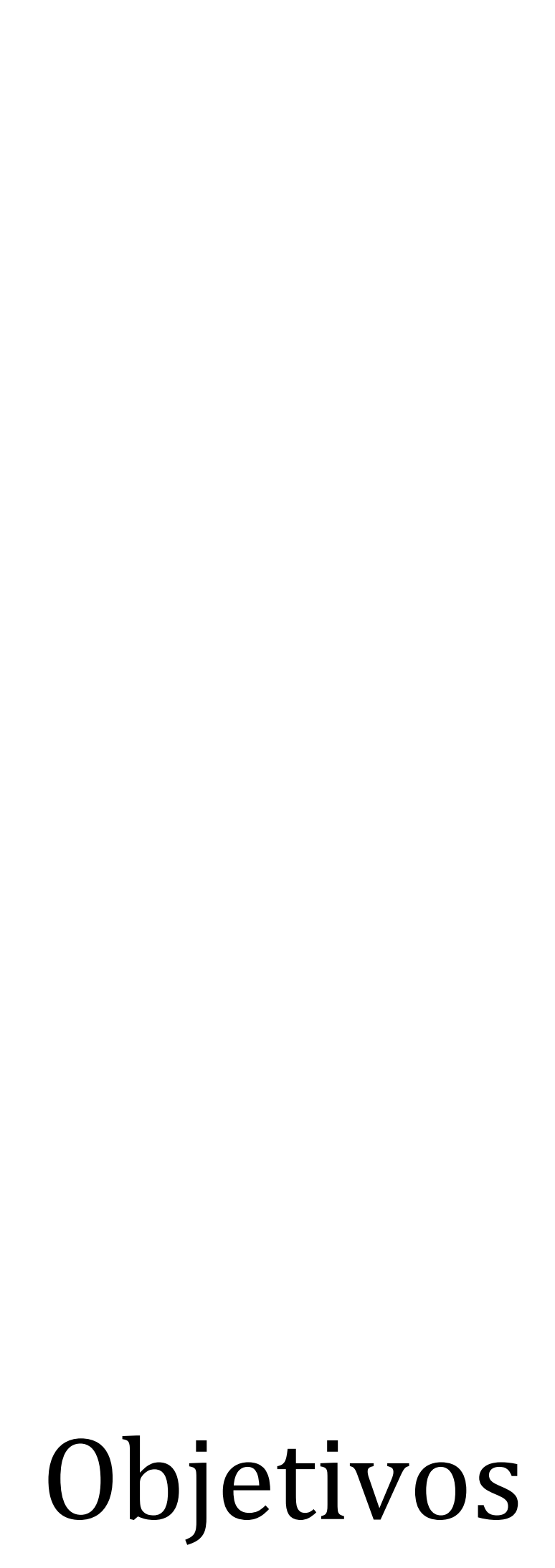




\section{Objetivos}

\subsection{Objetivos Gerais}

Modificação superficial de suportes de Ti por meio da deposição de filmes LB contendo a TNAP, a fim de aumentar a bioatividade da superfície. Verificar se este sistema induz maior formação de mineral na superfície modificada devido a atividade fosfohidrolítica da enzima imobilizada.

\subsection{Objetivos Específicos}

1. Avaliar a organização das monocamadas de lipídeos com diferentes cabeças polares em subfases contendo água pura e soluções aquosas de $\mathrm{CaCl}_{2}$, em diferentes concentrações;

2. Avaliar a condição ótima de deposição dos filmes LB sobre superfícies de Ti;

3. Avaliar e comparar as diferentes metodologias de imobilização da TNAP nos filmes LB;

4. Verificar a atividade fosfohidrolítica e a capacidade da TNAP imobilizada de induzir a formação de mineral in vitro;

5. Verificar a adesão e a proliferação de células osteogênicas nos suportes de Ti modificados com o filme LB em ausência e presença de TNAP. 


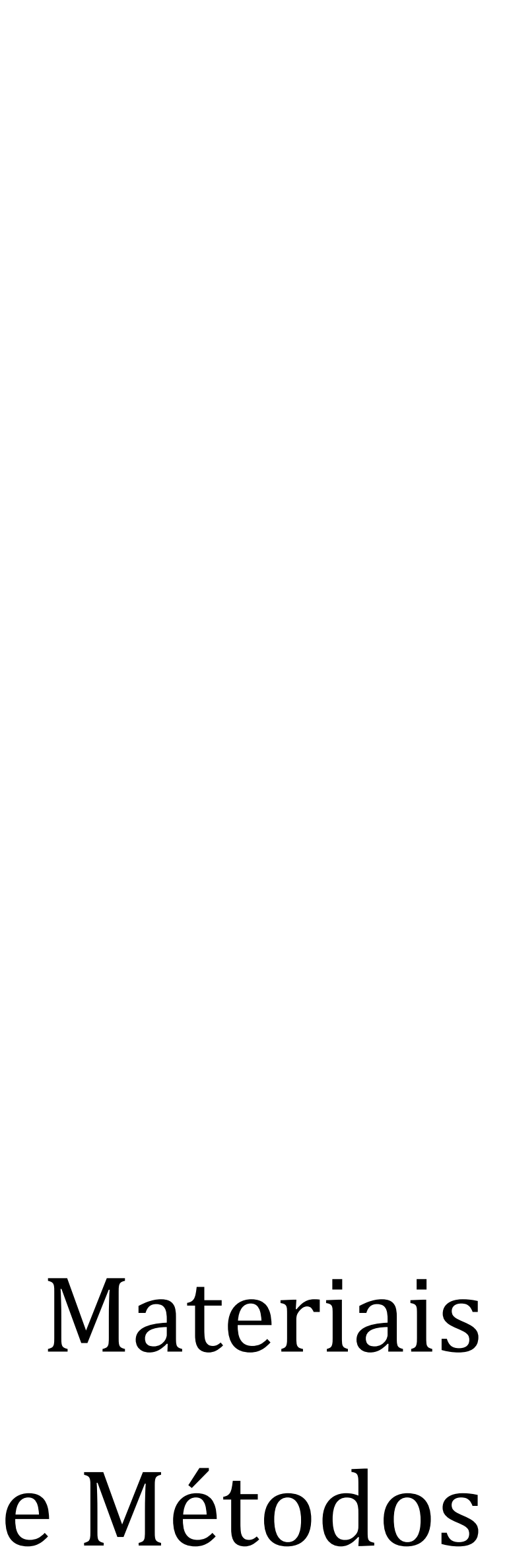




\section{Materiais e Métodos}

\subsection{Materiais}

Todas as soluções foram preparadas utilizando água purificada Milli-Q ${ }^{\circledR}(\gamma=$ $72,8 \mathrm{mN} \mathrm{m}^{-1}$ e resistividade de 18,2 $\mathrm{M} \Omega \mathrm{cm}$ ). 3[4,5-dimetiltiazol-2-il]-2,5-brometo difenil tetrazolium (MTT), Polioxietileno 9-lauril éter (polidocanol, $\mathrm{C}_{12}(\mathrm{EO})_{9}$ ), Span 20, cloreto de magnésio, cloreto de sódio, p-nitrofenilfosfato (pNFF), clorofórmio, tris(hidroximetil)aminoetano (Tris), 2-amino-2-metil propan-1-ol (AMPOL), colesterol (Chol) $(99+\%)$ e brometo de dioctadecildimetil amônio (DODAB) $(97+\%)$ foram adquiridos da Sigma. 1,2-dimiristoil-sn-glicero-3-fosfato (sal de sódio de DMPA) $(99+\%)$ e 1,2-dihexadecanoil-sn-glicero-3-fosfato (DPPC) (99+\%) foram obtidos da AVANTI Polar Lipids. Metanol $(\mathrm{MeOH}, 99+\%)$ e cloreto de cálcio foram obtidos da J.T. Baker. Calbiosorb foi adquirido da Merck-Millipore. Fosfatase alcalina humana foi obtida através da expressão em células ovarianas de hamster chinês segundo Simão et al. [97]. Expressão, extração e purificação da fosfatase alcalina foram realizadas no laboratório do Prof. Dr. Pietro Ciancaglini (Departamento de Química, FFCLRP - USP) e fornecida para nosso grupo.

\subsection{Obtenção da Fosfatase Alcalina Tecido Não-Específico}

A preparação e purificação da enzima em questão foi realizada segundo a metodologia descrita por Simão et al. [97]. Para tal, o cDNA (2,5 kb) de TNAP humana foi clonado em um vetor pCMV-Script (Stratagene, La Jolla, CA) a fim de expressar a forma nativa da TNAP. Um fragmento de DNA $(4,9 \mathrm{~kb})$ cobrindo a região-peptídio sinal do vetor pCMV-Script do sítio de ancoramento do grupo GPI foi amplificado por PCR a partir do vetor pCMV-Script da fosfatase alcalina na ausência da âncora, pela polimerase $p f x$ (Invitrogen), com o primer 5' e o primer 3'. As sequências amplificadas por PCR foram confirmadas por sequenciamento direto.

Células ovarianas de hamster chinês (CHO-K1, $\mathrm{n}^{\circ}$ ATCC CCL-61) foram tripsinizadas e $1,0 \times 10^{7}$ células foram suspensas em $800 \mathrm{~mL}$ de tampão salino HEPES, contendo $10 \mu \mathrm{g}$ do plasmídeo de cDNA da TNAP humana em um vetor pCMV-Script. 
A suspensão das células foi transferida para uma cubeta de eletroporação ( $4 \mathrm{~mm}$ de distância) e eletroporada em $400 \mathrm{mV}$, a 250 microfarads com o auxílio de um Gene Pulser (Bio-Rad). Após incubação no gelo durante 20 minutos, a suspensão de células eletroporadas foi diluída cerca de 250 x com meio de cultura (10\% de soro fetal bovino, meio de Dulbecco modificado do Eagle) e transferidas para placas de $15 \mathrm{~cm}$. Depois de 24h, o meio foi substituído por um meio de seleção, que foi renovado a cada 3 dias. Duas semanas depois, células G418-resistentes foram colhidas para a preparação das frações de membrana.

As células foram lavadas com tampão Tris- $\mathrm{HCl} 50 \mathrm{mmol} \mathrm{L}^{-1}(\mathrm{pH} 7,5)$, contendo $\mathrm{MgCl}_{2} 2 \mathrm{mmol} \mathrm{L}{ }^{-1}$, removidas com uma espátula e ressuspendidas em tampão Tris-HCl $50 \mathrm{mmol} \mathrm{L}^{-1}$, contendo $\mathrm{MgSO}_{4} 10 \mathrm{mmol} \mathrm{L}^{-1}$ e $\mathrm{NaCl}$ 0,8 mol L${ }^{-1}$. A suspensão celular foi homogeneizada com o auxílio de um homogeneizador do tipo Potter-Elvehjem, para uma ruptura celular branda, a $4{ }^{\circ} \mathrm{C}$ por 15 minutos, centrifugada a $1000 \mathrm{~g}$ por 3 minutos e finalmente o sobrenadante foi ultracentrifugado a $100000 \mathrm{~g}$ por 1 hora a $4{ }^{\circ} \mathrm{C}$. O pellet correspondendo à fosfatase alcalina ligada à membrana, foi ressuspenso em tampão Tris- $\mathrm{HCl} 50$ mmol L-1 $(\mathrm{pH} 7,5)$, contendo $\mathrm{MgCl}_{2} 2 \mathrm{mmol} \mathrm{L}{ }^{-1}$. Tais frações de membrana ricas em TNAP $\left(0,2 \mathrm{mg} \mathrm{mL}^{-1}\right)$ foram solubilizadas com polidocanol $1 \% \mathrm{p} / \mathrm{V}$ durante 1 hora a $25{ }^{\circ} \mathrm{C}$, sob agitação constante; obtendo TNAP na presença do detergente (de aproximadamente $0,05 \mathrm{mg} \mathrm{mL}^{-1}$ ). Após centrifugação a $100000 \mathrm{~g}$ durante 1 hora, $1 \mathrm{~mL}$ de TNAP solubilizada foi incubada em $200 \mathrm{mg}$ de uma resina hidrofóbica (Calbiosorb) durante 2 horas a $4{ }^{\circ} \mathrm{C}$, sob agitação constante para a obtenção da TNAP (de aproximadamente $0,03 \mathrm{mg} \mathrm{mL}^{-1}$ ) na ausência do detergente não-iônico [135]. A dosagem da concentração protéica foi estimada na presença de SDS 2\% p/V e albumina de soro fetal bovino foi utilizada como padrão [136].

\subsection{Monocamadas de Langmuir}

\subsubsection{Monocamadas dos lipídeos puros}

As monocamadas de lipídeos foram confeccionadas em uma cuba de Langmuir (Insight $^{\circledR}$, área superficial de $216 \mathrm{~cm}^{2}$ e volume de aproximadamente $130 \mathrm{~mL}$ ) a $25 \pm 2$ ${ }^{\circ} \mathrm{C}$, por meio do espalhamento de $30 \mu \mathrm{L}$ de uma solução clorofórmica $\left(\mathrm{CHCl}_{3}: \mathrm{MeOH}\right.$ 3:1 v/v) de DODAB, DPPC ou DMPA $1 \mathrm{mmol} \mathrm{L}^{-1}$ (ou uma mistura binária de lipídeo e colesterol, com concentração final $1 \mathrm{mmol} \mathrm{L}^{-1}$ ) (Figura 15) sobre a interface líquido-ar. 
A subfase foi constituída por água pura ou soluções aquosas de $\mathrm{CaCl}_{2}$. Após um intervalo de 5 minutos (necessário para evaporação do solvente), a interface contendo os lipídeos foi comprimida mecanicamente por uma barreira móvel, a uma taxa de 0,42 $\mathrm{mm} \mathrm{s} \mathrm{s}^{-1}$, registrando a isoterma $\pi$-A. Os valores dos módulos compressionais foram calculados a partir da taxa de variação de $\pi$ em função da área molecular utilizando-se a

\section{Equação 2.}

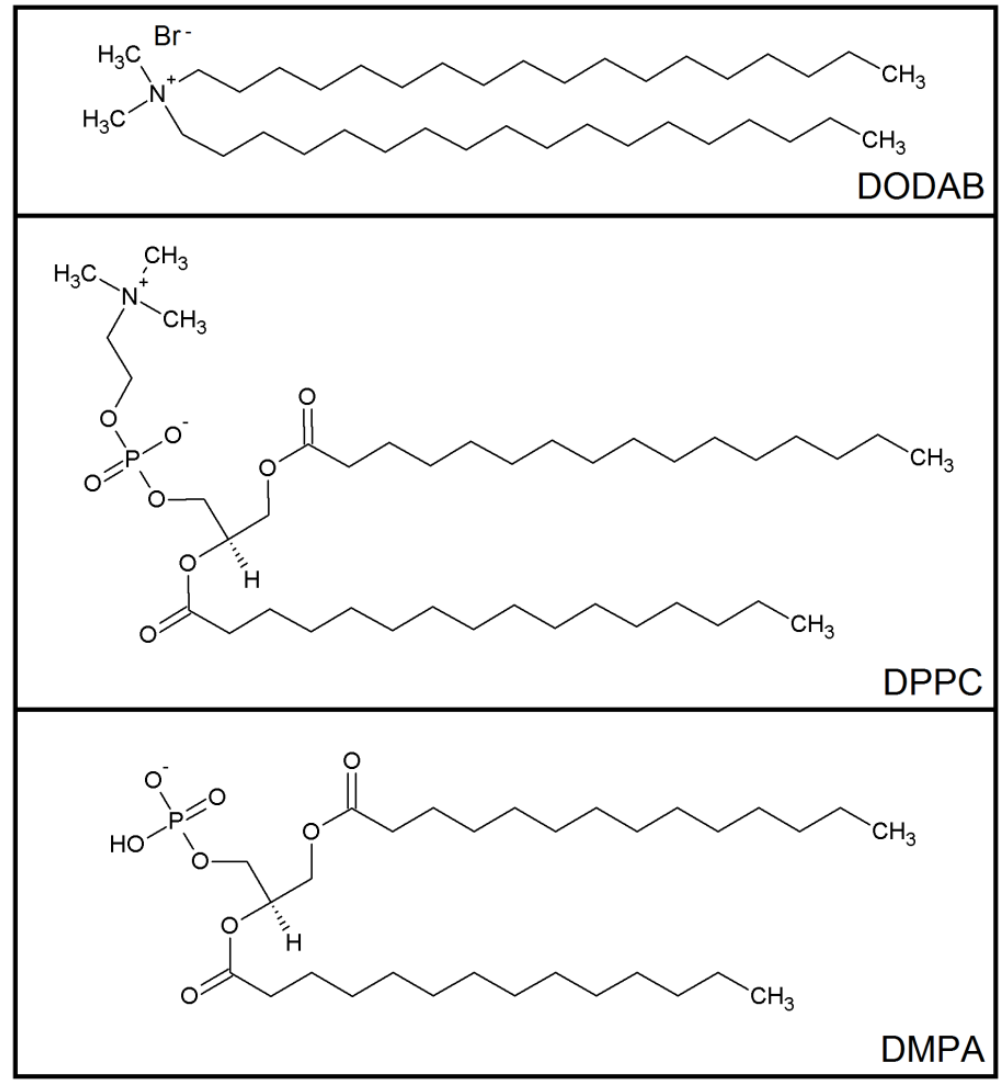

Figura 15 - Fórmulas estruturais dos tensoativos utilizados na confecção das monocamadas de Langmuir e dos filmes LB.

\subsubsection{Atividade Superficial e Monocamadas de TNAP}

A atividade superficial da TNAP foi avaliada por meio de medidas em tempo real de $\gamma$ através de ADSA, em um microambiente de uma gota pendente de água pura (13 $\mu \mathrm{L})$ a $25 \pm 2{ }^{\circ} \mathrm{C}$. Para isso, uma solução de TNAP na ausência $\left(27,1 \mu \mathrm{g} \mathrm{mL}{ }^{-1}\right) \mathrm{e}$ presença $\left(54 \mu \mathrm{g} \mathrm{mL}^{-1}\right)$ de polidocanol $1 \% \mathrm{p} / \mathrm{V}$, foi injetada na gota com auxílio de uma microseringa. As medidas de $\gamma$ em função do tempo foram realizadas utilizando um tensiômetro automático OCA-20 (Dataphysics ${ }^{\circledR}$ ) (Figura 16), conforme descrito no artigo recentemente publicado [134]. 
Monocamadas da enzima pura foram também obtidas em uma cuba de Langmuir a $25 \pm 2{ }^{\circ} \mathrm{C}$, por meio da injeção de uma solução de TNAP em uma subfase contendo água pura ou solução salina, na ausência (concentração de TNAP 27,1 $\mu \mathrm{g} \mathrm{mL}^{-1}$ ) e presença (concentração de TNAP $54 \mu \mathrm{g} \mathrm{mL}^{-1}$ ) de polidocanol $1 \% \mathrm{p} / \mathrm{V}$, após 5 minutos, com compressão mecânica a $0,42 \mathrm{~mm} \mathrm{~s}^{-1}$. Os valores dos módulos compressionais foram calculados a partir da taxa de variação de $\pi$ em função da área superficial utilizando-se a Equação 2.

\subsubsection{Monocamadas Mistas de Lipídeos e TNAP}

As monocamadas mistas foram confeccionadas a partir do espalhamento na interface ar-líquido de $30 \mu \mathrm{L}$ de solução clorofórmica $1 \mathrm{mmol} \mathrm{L}^{-1}$ do lipídeo com posterior adição de diferentes volumes de solução de TNAP na ausência $\left(27,1 \mu \mathrm{g} \mathrm{mL}^{-1}\right)$ e presença $\left(54 \mu \mathrm{g} \mathrm{mL}^{-1}\right)$ de polidocanol $1 \% \mathrm{p} / \mathrm{V}$, em subfase constituída de água pura ou soluções salinas. Após um intervalo de 5 minutos as monocamadas foram sujeitas à compressão mecânica a $0,42 \mathrm{~mm} \mathrm{~s}^{-1}$, registrando a isoterma de $\pi$ em função da área superficial, considerando apenas o número de moléculas de lipídeo espalhado a fim de estimar a área molecular representada nas isotermas $\pi-\mathrm{A}$. Os valores dos módulos compressionais foram calculados a partir da taxa de variação de $\pi$ em função da área molecular utilizando-se a Equação 2.

Ensaios de estabilidade da monocamada, na ausência e presença de TNAP sem polidocanol, foram realizados por meio da compressão da mesma até $\pi=30 \mathrm{mN} \mathrm{m}^{-1}$, registrando-se posteriormente os valores de $\pi$ em função do tempo. Também estudou-se a histerese das monocamadas mistas por meio de ciclos de compressão/expansão desta até uma pressão superficial de $40 \mathrm{mN} \mathrm{m}^{-1}$.

A morfologia das monocamadas puras de lipídeo ou mistas com TNAP foram caracterizadas utilizando-se BAM (BAM2 Plus-Nanofilm Technologies Germany ${ }^{\circledR}$ laboratório do Grupo de Polímeros Prof. Bernhard Gross-IFSC/USP), equipado com uma lente objetiva de 10x, laser incidente a um ângulo de $53,1^{\circ}$ ). Foi realizado o espalhamento de $30 \mu \mathrm{L}$ de solução clorofórmica $1 \mathrm{mmol} \mathrm{L}^{-1}$ do lipídeo (para a monocamada mista, foi posteriormente injetado um volume da solução de TNAP 27,1 $\mu \mathrm{g} \mathrm{mL}^{-1}$ na ausência de polidocanol) sobre uma subfase de solução salina, utilizando-se uma cuba de Langmuir KSV-Nima (Biolin Scientific ${ }^{\circledR}$, área total de $23400 \mathrm{~mm}^{2}$ ) à qual estava acoplado o BAM. As imagens foram obtidas em tempo real à compressão (em 
diferentes valores de $\pi$ ) da monocamada com o auxílio de 2 barreiras mecânicas movendo-se a $10 \mathrm{~mm} \mathrm{~min}^{-1}$.

Finalmente, o valor de $\pi_{\text {ezc. }}$ da TNAP nas monocamadas foi averiguada em uma subfase de solução salina (volume de aproximadamente $13 \mathrm{~mL}$ ) contida em um recipiente cilíndrico de vidro (com área superficial de $16,9 \mathrm{~cm}^{2}$ ), com uma placa de Wilhelmy de um tensiômetro $\left(\right.$ Insight $^{\circledR}$ ) interceptando a interface para medidas de $\pi \mathrm{em}$ função do tempo. Para isso, foi espalhada a solução clorofórmica do lipídeo ou mistura de lipídeo/colesterol (ambos com concentração final de $1 \mathrm{mmol} \mathrm{L}^{-1}$ ) até a pressão inicial $\left(\pi_{\mathrm{i}}\right)$ de interesse e com posterior injeção de TNAP (sem polidocanol) sob a monocamada já formada, registando as posteriores variações de pressão de superfície $(\Delta \pi)$. A extrapolação gráfica do $\pi_{\mathrm{i}}$ necessário para que $\Delta \pi$ seja nulo é o valor de $\pi_{\mathrm{exc}}$.

\subsection{Filmes Langmuir Blodgett}

Todos os filmes LB foram construídos a partir de ciclos de imersão/emersão de um suporte sólido através das monocamadas formadas sobre subfases contendo água pura ou soluções salinas, mantendo-se $\pi$ constante em $30 \mathrm{mN} \mathrm{m}^{-1}$. A primeira transferência foi sempre realizada a partir da emersão, com posteriores ciclos de imersão/emersão a fim de confeccionar filmes LB do tipo Y. As razões de transferência foram calculadas por meio do quociente entre a área do suporte sólido e a área da cuba que foi comprimida durante a compensação da transferência ao suporte (Equação 3).

\subsubsection{Preparo dos Suportes Sólidos}

Um cristal de quartzo redondo (diâmetro e área total de $1,37 \mathrm{~cm}$ e $2,96 \mathrm{~cm}^{2}$, respectivamente) recoberto com ouro (ICM Crystals; área recoberta com Au equivalente a $0,662 \mathrm{~cm}^{2}$ ) foi utilizado na confecção e caracterização microgravimétrica de filmes LB dos lipídeos puros. Antes da transferência dos filmes, a limpeza destes suportes foi realizada por ultrassonicação em água Milli-Q, posteriormente friccionando-os levemente contra lenços de papel com clorofórmio.

$\mathrm{Na}$ preparação de filmes LB mistos de lipídeo/TNAP foram utilizados como suportes sólidos uma placa retangular de quartzo (dimensões 1,2 x 1,56 cm e área total de $3,74 \mathrm{~cm}^{2}$ ), cuja limpeza foi realizada introduzindo-os em solução piranha (mistura de 3 volumes de $\mathrm{H}_{2} \mathrm{SO}_{4}$ concentrado com 1 volume de $\mathrm{H}_{2} \mathrm{O}_{2}$ ), posteriormente 
ultrassonicando-o em água Milli-Q e finalmente friccionando-os levemente contra lenços de papel com clorofórmio. Também foram utilizados discos circulares de Ti $\left(\right.$ REALUM $^{\circledR}$, com diâmetro, largura e área de 1,3 x $0,15 \mathrm{~cm}$ e 2,79 cm², respectivamente), cuja limpeza foi realizada por ultrassonicações durante 15 minutos em diferentes meios (solução com detergente comercial à base de dodecil sulfato de sódio, seguido por álcool etílico $70 \%$ e finalmente em acetona pura). Anteriormente ao uso destes suportes na construção dos filmes LB, foram realizadas ultrassonicações durante 5 minutos a $65{ }^{\circ} \mathrm{C}$ em um tampão de $\mathrm{KH}_{2} \mathrm{PO}_{4} / \mathrm{NaOH} 0,1 \mathrm{~mol} \mathrm{~L}{ }^{-1}(\mathrm{pH} 7,5)$ contendo o surfactante não-iônico Span 20 a 0,04 mmol L-1 (com exaustiva lavagem em água Milli-Q®), finalmente expondo os suportes durante 2 minutos em uma descarga de plasma de Nitrogênio (Harrick Scientific Plasma Cleaner).

\subsubsection{Filmes LB dos Lipídeos Puros}

Os filmes LB dos lipídeos puros foram construídos a partir do espalhamento de 30 $\mu \mathrm{L}$ de solução clorofórmica dos mesmos (de concentração final de $1 \mathrm{mmol} \mathrm{L}^{-1}$ ) sobre subfases contendo água pura ou soluções salinas, com um intervalo de espera de 5 minutos e posterior compressão mecânica da interface a $0,42 \mathrm{~mm} \mathrm{~s}^{-1}$ até a pressão de deposição $\left(\pi=30 \mathrm{mN} \mathrm{m}^{-1}\right)$, a $25 \pm 2{ }^{\circ} \mathrm{C}$. Os filmes de números pares de camadas (final hidrofílico) foram mantidos em solução tampão (Tris- $\mathrm{HCl} 50 \mathrm{mmol} \mathrm{L}{ }^{-1} \mathrm{pH} 7,5$ e $\mathrm{MgCl}_{2}$ $2 \mathrm{mmol} \mathrm{L}^{-1}$ ) de forma a se evitar o flip-flop das monocamadas.

\subsubsection{Filmes LB Mistos de Lipídeo e TNAP Fisicamente Adsorvida}

Filmes LB de DMPA ( $\mathrm{n}=2,3$ ou 4) foram construídos sobre um suporte sólido a partir de uma subfase de $\mathrm{CaCl}_{2} 0,1 \mathrm{mmol} \mathrm{L}{ }^{-1}$, posteriormente expostos a uma solução de TNAP 2,64 $\mu \mathrm{g} \mathrm{mL}^{-1}$ (na ausência de polidocanol) com o auxílio de um dip-coater durante um intervalo de tempo de 15 minutos (ou ainda por diversos ciclos de imersãoremoção por pequenos intervalos de tempos), com posterior enxágue em um tampão pH 7,5 (Tris- $\mathrm{HCl} 50 \mathrm{mmol} \mathrm{L}^{-1}$ e $\mathrm{MgCl} 2 \mathrm{mmol} \mathrm{L}^{-1}$ ). Suportes de quartzo (com área superficial de $3,74 \mathrm{~cm}^{2}$ ) foram utilizados nos ensaios de cinética enzimática, um suporte de plástico (com área superficial de 2,65 $\mathrm{cm}^{2}$ ) e discos de Ti (com área superficial de $2,79 \mathrm{~cm}^{2}$ ) nos ensaios de mineralização. 


\subsubsection{Filmes LB Mistos de Lipídeo e TNAP}

Para a confecção dos filmes LB a partir das monocamadas mistas DMPA/ $\mathrm{Ca}^{2+} /$ TNAP foi necessário o uso de subfase constituída por uma solução de alta força-iônica (aqui induzida por $\mathrm{CaCl}_{2}$ ), a fim de garantir a adsorção da enzima na interface. $\mathrm{Na}$ confecção de filmes com 2 camadas (a partir de subfase contendo $\mathrm{CaCl}_{2}$ ), primeiramente uma camada contendo apenas o lipídeo foi depositada sobre um suporte sólido a partir da emersão. Posteriormente foi realizado o espalhamento de $30 \mu \mathrm{L}$ de solução clorofórmica de DMPA $1 \mathrm{mmol} \mathrm{L}^{-1}$, seguido da injeção de um volume determinado de solução de TNAP 27,1 $\mu \mathrm{g} \mathrm{mL}^{-1}$ (na ausência de polidocanol). Após um intervalo de 5 minutos, a interface foi comprimida até a pressão de deposição, transferindo a monocamada mista sobre o filme de DMPA pré-formado sobre o suporte sólido. Para estes tipos de filmes, apenas os discos de Ti foram utilizados como suportes sólidos.

Para medidas de nanogravimétricas, um filme LB com uma camada foi construído sobre um suporte de QCM, a partir da monocamada mista DMPA/TNAP (formada de maneira análoga à descrita anteriormente, sobre subfase constituída por solução de $\mathrm{CaCl}_{2}$ ), após a compressão da mesma até $\pi=30 \mathrm{mN} \mathrm{m}^{-1}$.

\subsubsection{Medidas Nanogravimétricas}

Cristais de quartzo recobertos com ouro (ICM Crystals, área ativa 0,662 $\mathrm{cm}^{2}$ ) foram utilizados nas medidas nanogravimétricas por microgravimetria de cristal de quartzo (QCM), medindo a variação das frequências de oscilação (ICM Oscilator 35366) antes e após a deposição do filme LB (após enxague do suporte com água corrente), determinando-se a massa depositada por meio da Equação 4. Os resultados foram relatados como a média de uma triplicata ( \pm desvio padrão das amostras).

\subsection{Atividade Fosfohidrolítica da TNAP}

\subsubsection{Em Meio Homogêneo}

A atividade fosfohidrolítica da TNAP foi estimada continuamente por meio da hidrólise do substrato sintético $p$-nitrofenil fosfato (pNFF, denominando de atividade 
pNFFase) utilizando-se de espectrofotometria UV-Vis tradicional (Agilent/HP 8453). Em meio homogêneo, foi adicionado $20 \mu \mathrm{L}$ de TNAP, a um meio reacional constituído de AMPOL $50 \mathrm{mmol} \mathrm{L}^{-1}$ (pH 10), pNFF $10 \mathrm{mmol} \mathrm{L}^{-1}$ e $\mathrm{MgCl}_{2} 2 \mathrm{mmol} \mathrm{L}^{-1}$ (volume final de $500 \mu \mathrm{L}$ ), registrando os espectros UV-Vis em função do tempo. A concentração em proteínas das amostras de TNAP usadas foram 27,1 e $54 \mu \mathrm{g} \mathrm{mL}^{-1}$ na ausência e presença de polidocanol $1 \% \mathrm{p} / \mathrm{V}$, respectivamente.

A atividade enzimática foi estimada por meio das mudanças de intensidade das absorbâncias em $410 \mathrm{~nm}$, atribuída à formação de $p$-nitrofenolato ( $\mathrm{pNF}^{-}$). A atividade específica foi calculada em nmol de fosfato inorgânico produzido $\left(\mathrm{P}_{\mathrm{i}}\right)$ em função do tempo e normalizada pela massa de enzima (em mg).

Como controle também foi estimada a atividade pNFFase na presença de gentamicina $50 \mu \mathrm{g} \mathrm{mL}^{-1}$ e fungizona $0,3 \mu \mathrm{g} \mathrm{mL}^{-1}$ (isoladamente e em conjunto) a fim de verificar se estes antibióticos (utilizados em experimentos de mineralização a fim de inibir a proliferação de microrganismos indesejados) provocam alguma influência na atividade fosfohidrolítica da TNAP em solução. Os resultados foram relatados como a média de uma triplicata ( \pm desvio padrão das amostras).

\subsubsection{Em uma Gota Pendente}

A padronização da análise da atividade pNFFase da TNAP (sem polidocanol) em uma gota pendente foi realizada utilizando um fator de correção correspondente ao coeficiente angular da dependência dos valores de absorbância (registrados utilizandose da espectrofotometria DRUV em uma gota pendente, Figura 16) [134] em função da concentração de $\mathrm{pNF}^{-}$. Para obter a relação entre estas variáveis, um meio reacional constituído de AMPOL 50 mmol L-1 (pH 10), pNFF 10 mmol L-1 e $\mathrm{MgCl}_{2} 2 \mathrm{mmol} \mathrm{L}^{-1}$ (volume final de $1 \mathrm{~mL}$ ) foi incubado em uma cubeta de quartzo (caminho óptico de 1,00 $\mathrm{cm}$ ) contendo $0,528 \mu \mathrm{g}$ de TNAP. Os espectros UV-Vis do produto foram registrados em função do tempo utilizando-se espectrofotometria UV-Vis tradicional (Agilent/HP 8453). Após 5 minutos de reação, esta mesma solução foi transferida ao aparato de DRUV-ADSA e os espectros UV-Vis também foram registrados em função do tempo. Os valores de $\mathrm{A}_{410 \mathrm{~nm}}$ obtidos pela técnica DRUV-ADSA foram graficados em função das concentrações de $\mathrm{pNF}^{-}$, calculadas pela lei de Lambert-Beer $\left(\varepsilon_{410 \mathrm{~nm}}=17600 \mathrm{M}^{-1} \mathrm{~cm}^{-}\right.$ ${ }^{1} \mathrm{em} \mathrm{pH}$ 10), para intervalos de tempo equivalentes à análise espectrofotométrica em uma cubeta. A atividade específica foi calculada em unidades de nmol de fosfato 
inorgânico produzido $\left(\mathrm{P}_{\mathrm{i}}\right)$ em função do tempo e normalizada pela massa de enzima (em $\mathrm{mg})$.

A atividade enzimática da TNAP na gota pendente foi determinada posteriormente com a injeção de $0,5 \mu \mathrm{L}$ de solução de TNAP $26,4 \mu \mathrm{g} \mathrm{mL} \mathrm{m}^{-1}$ a uma gota de meio reacional, registrando os valores de $\mathrm{A}_{410 \mathrm{~nm}}$ (em função do tempo), posteriormente convertidos em concentração de $\mathrm{pNF}^{-}$ao serem divididos pelo fator (com unidade $\mathrm{L} \mathrm{mol}^{-1}$ de $\mathrm{pNF}^{-}$), que fora determinado na padronização da metodologia. Os resultados foram relatados como a média de uma triplicata ( \pm desvio padrão das amostras).

\subsubsection{Imobilizada em Filmes Mistos de DMPA/Ca ${ }^{2+} /$ TNAP}

A atividade fosfohidrolítica da TNAP imobilizada em filmes LB do tipo Y (confeccionados segundo as condições descritas nas seções 3.4.3 e 3.4.4) também foi estimada continuamente, expondo os suportes sólidos contendo os filmes mistos em uma placa de 24 poços, contendo meio reacional constituído de AMPOL 50 mmol L ${ }^{-1}$ (pH 10), pNFF $10 \mathrm{mmol} \mathrm{L}^{-1}$ e $\mathrm{MgCl}_{2} 2 \mathrm{mmol} \mathrm{L}^{-1}$ (volume final de 1,5 mL). Após um determinado intervalo de tempo foram registrados os espectros UV-Vis transferindo as soluções, com o auxílio de micropipetas, a uma cubeta de quartzo (caminho óptico de $1,00 \mathrm{~cm}$ ) em um espectrofotômetro tradicional (Agilent/HP 8453). Como controle, foi incubado um suporte sólido modificado com um filme LB (sob mesmas condições) na ausência da TNAP. Os resultados foram relatados como a média de uma triplicata ( \pm desvio padrão das amostras).

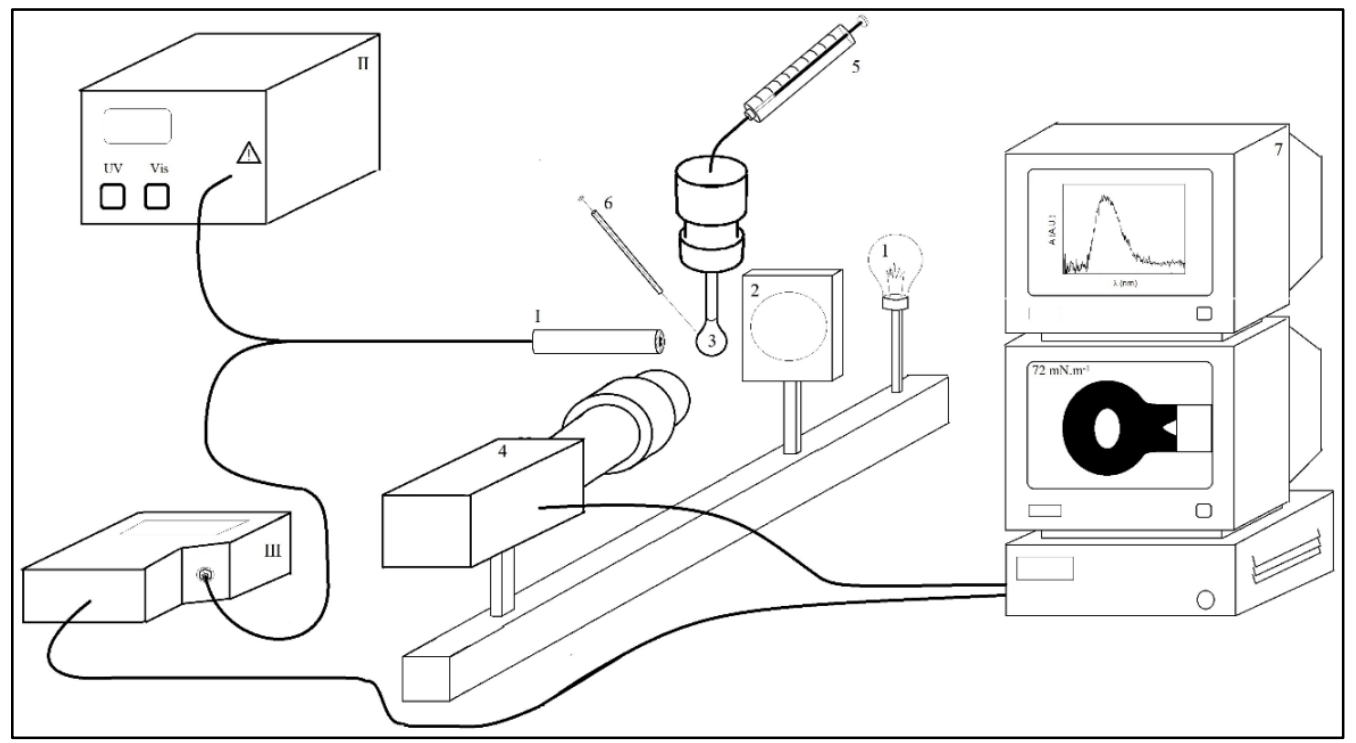


Figura 16 - Diagrama esquemático dos experimentos DRUV-ADSA: (1) fonte de luz; (2) difusor; (3) gota pendente; (4) câmera CCD; (5) seringa; (6) microsseringa de injeção; (7) compudator; (I) fibra ótica-sonda de reflectância difusa; (II) lâmpadas de deutério/halogênio; (III) espectrofotômetro.

\subsection{Mineralização dos Filmes Mistos}

Os ensaios de mineralização dos filmes LB mistos foram realizados expondo os mesmos a uma solução contendo um substrato fosforilado (ATP) e centros de nucleação, que são fosfato de cálcio amorfo (ACP) e seu complexo com fosfatidilserina (PS-CPLX), preparados segundo Simão et al. [98]. Uma emulsão de fosfatidilserina (PS) foi preparada secando 1,25 mg de PS em clorofórmio sob fluxo de $\mathrm{N}_{2}$, a fim de formar uma fina camada em um tubo teste. Posteriormente, $2 \mathrm{~mL}$ de um tampão rico em fosfato intracelular foi adicionado. Este tampão continha $106,7 \mathrm{mmol} \mathrm{L}^{-1}$ de $\mathrm{K}^{+}, 45,1$

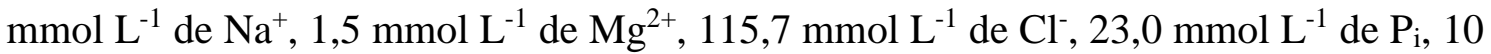
mmol L ${ }^{-1}$ de $\mathrm{HCO}_{3}{ }^{-}, 1,5 \mathrm{mmol} \mathrm{L}{ }^{-1}$ de $\mathrm{SO}_{4}{ }^{2-}$ e $3,1 \mathrm{mmol} \mathrm{L}^{-1}$ de $\mathrm{N}^{3-}$; com concentração

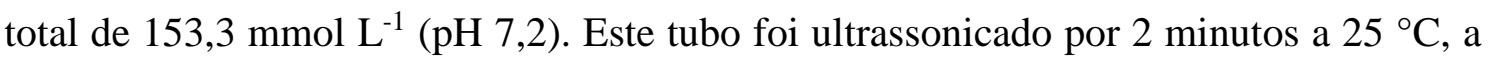
fim de formar uma emulsão uniforme translúcida de pequenas vesículas unilamelares. Finalmente, $17,5 \mathrm{~mL}$ de $\mathrm{CaCl}_{2} 100 \mathrm{mmol} \mathrm{L}^{-1}$ foi adicionado a $1 \mathrm{~mL}$ da emulsão de PS sob rápida agitação. $\mathrm{Na}$ adição de $\mathrm{Ca}^{2+}$ ao tampão, a concentração de supersaturação é atingida e forma-se ACP instantaneamente. Os núcleos de ACP recém-formados combinam-se com os lipossomos de PS, formando o complexo PS-CPLX insolúvel, que é isolado por centrifugação durante 5 minutos a $15000 \mathrm{~g}$. Os pellets foram ressuspensos em $1 \mathrm{~mL}$ de tampão Tris $16,5 \mathrm{mmol} \mathrm{L}^{-1}(\mathrm{pH}$ ), por uma breve sonicação a fim de formar suspensões uniformes.

\subsubsection{Análise da Formação de Mineral por Turbidimetria}

Os suportes sólidos contendo os filmes LB mistos de DMPA/Ca ${ }^{2+} / \mathrm{TNAP}$ (confeccionados segundo as condições descritas nas seções 3.4.3 e 3.4.4) foram expostos à solução SCL (constituída de ATP $1 \mathrm{mmol} \mathrm{L}^{-1}$ (fonte de $\mathrm{P}_{\mathrm{i}}$ ), $\mathrm{Ca}^{2+} 2 \mathrm{mmol} \mathrm{L}^{-1}$,

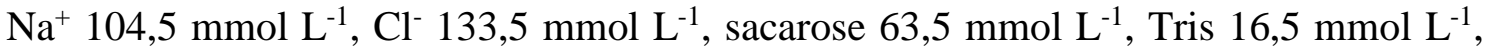
$\mathrm{K}^{+} 12,7 \mathrm{mmol} \mathrm{L}^{-1}$, glicose 5,55 $\mathrm{mmol} \mathrm{L}^{-1}, \mathrm{HCO}_{3}{ }^{-} 1,83 \mathrm{mmol} \mathrm{L}^{-1}$ e $\mathrm{MgSO}_{4}$ 0,57 $\mathrm{mmol} \mathrm{L}^{-}$ ${ }^{1}$ ), contendo os centros de nucleação. Filmes na ausência de TNAP foram utilizados como controle. A formação do mineral foi quantificada por análise espectrofotométrica 
em $340 \mathrm{~nm}$ em microplacas de 12 poços. As medidas de absorbância foram realizadas após uma agitação branda (10 segundos) e sob incubação a $37^{\circ} \mathrm{C}$, durante intervalos de tempos determinados, utilizando um leitor de microplacas Molecular Devices Spectramax M3 ${ }^{\circledR}$. Os resultados foram relatados como a média de uma triplicata $( \pm$ desvio padrão das amostras).

\subsubsection{Análise Morfológica das Superfícies de Ti Modificadas}

A análise morfológica das superfícies de Ti, modificadas com os filmes LB (após exposição ao SCL) foi realizada utilizando-se microscopia eletrônica de varredura (MEV) (Shimadzu SS-550 Superscan, Departamento de Química-FFCLRP) com voltagem de aceleração de $20 \mathrm{mV}$. Previamente às análises, as amostras foram recobertas com ouro utilizando pulverização catódica (Bal-Tec, SCD-050 Sputter Coater, por 110 segundos).

\subsubsection{Análise Composicional das Superfícies de Ti Modificadas}

Os grupos químicos contidos nas superfícies de Ti, modificadas com os filmes LB (após exposição ao SCL), foram identificados por espectroscopia de FTIR acoplada a um acessório de ATR (Shimadzu-IR Prestige-21 - Laboratório de Terras-Raras/DQFFCLRP). A análise dos elementos presentes nestas superfícies foi realizada por espectroscopia de energia dispersiva de raio X (EDX, IXRF System 500 Digital Processer - Departamento de Química-FFCLRP). Finalmente, os padrões de difração das superfícies das amostras foram obtidos por DRX (Bruker-AXS D5005 Departamento de Química-FFCLRP), operando uma radiação K $\alpha$ de $\mathrm{Cu}$ com ângulo de incidência rasante.

\subsubsection{Energia Livre Superficial e Molhabilidade}

A molhabilidade das superfícies de Ti modificadas com os filmes LB (antes e após exposição ao SCL) foi determinada por meio da medida dos ângulos de contato (Dataphysics OCA20) formados entre uma gota de água e os suportes sólidos. A energia livre superficial $\left(\gamma_{S}\right)$ foi determinada medindo os ângulos de contato de três solventes sobre as superfícies de $\mathrm{Ti}$ modificadas (formamida, diiodometano e água); 
determinando o valor de $\gamma_{S}$ (e suas componentes polar e dispersiva, $\gamma_{S}{ }^{\mathrm{P}}$ e $\gamma_{S}{ }^{\mathrm{d}}$ ) por meio do ajuste destas variáveis na equação de Owens-Wendt-Kaeble (Equação 6). Os resultados foram relatados como a média de uma triplicata $( \pm$ desvio padrão das amostras).

\subsubsection{Viabilidade Celular Sobre as Superfícies de Ti Modificadas}

A viabilidade celular de células osteoblásticas sobre as superfícies de Ti, modificadas com os filmes LB, foi determinada por meio do ensaio colorimétrico clássico do MTT. Para tal, uma suspensão de 1,8 x $10^{5}$ células (osteoblastos, em 0,5 mL de meio de cultura) foi adicionada a cada poço de uma microplaca (de 24 poços), contendo os discos de Ti, modificados ou não com os filmes $\mathrm{LB}$, incubados a $37{ }^{\circ} \mathrm{C}$ por diferentes intervalos de tempo. Posteriormente, $1 \mathrm{~mL}$ de solução de MTT 1,0 mg mL ${ }^{-1}$ foi adicionada aos poços, seguido de incubação durante 4 horas a $37{ }^{\circ} \mathrm{C}$. Os cristais resultantes da interação entre as desidrogenases mitocondriais e o MTT foram dissolvidos com 2-propanol; as amostras sofreram agitação até que todo o produto fosse dissolvido completamente. Após a completa reação, as absorbâncias de cada poço foram determinadas em 560 e $690 \mathrm{~nm}$ (Genesys 2). A viabilidade celular foi expressa como uma porcentagem da média de duplicatas comparadas com o controle (células que cresceram sobre um disco de Ti na ausência de modificação superficial). Os resultados foram relatados como a média de uma triplicata ( \pm desvio padrão das amostras).

\subsubsection{Morfologia Celular}

A morfologia dos osteoblastos cultivados sobre as superfícies de Ti, modificadas com os filmes LB, foi determinada através de MEV, utilizando um microscópio JSM6610 LV (Jeol) da Faculdade de Medicina de Ribeirão Preto. Para tal, foi realizado cultivo celular descrito no item 3.6.5, sobre a superfície de discos de Ti, modificados ou não com os filmes LB. Posteriormente ao tempo de cultivo, as células foram fixadas aos suportes com glutaraldeído $4 \%$ em tampão monossódico dipotássico $0,2 \mathrm{~mol} \mathrm{~L}^{-1}$, desidratadas em gradiente de etanol, tratadas com $\mathrm{OsO}_{4}$ [137] e recobertas com ouro. 
Resultados e Discussão 


\section{Resultados e Discussão}

\subsection{Caracterização das Monocamadas dos Lipídeos}

Inicialmente, foi realizada a caracterização das monocamadas de Langmuir dos lipídeos em subfases constituídas de água pura ou soluções com diferentes concentrações de $\mathrm{CaCl}_{2}$. A escolha de um sal de cálcio justifica-se na co-adsorção deste cátion nos filmes LB confeccionados a partir das monocamadas, visando uma condição favorável para posterior formação de minerais de fosfato de cálcio, sobre superfícies recobertas com estes filmes.

A fim de comparar o efeito de diferentes cargas nas cabeças polares dos lipídeos na organização das monocamadas, foram utilizados os lipídeos DODAB, DPPC e DMPA, com cargas líquidas positiva, neutra (zwitteriônica) e negativa respectivamente; a fim de obter uma condição ótima (em conjunto com $\mathrm{CaCl}_{2}$ ) para posterior confecção de filmes LB.

As isotermas $\pi$-A de DODAB estão representadas na Figura 17. Em água pura, a $\pi$ aumenta exponencialmente com a compressão da monocamada (Figura 17A), que atinge fases condensadas a partir de áreas moleculares menores que $60 \AA^{2}$ molécula $^{-1}$ (Figura 17B) e sofre colapso acima de $50 \mathrm{mN} \mathrm{m}^{-1}$. A literatura relata a obtenção de isotermas $\pi$-A [74,138,139] e curvas de $\mathrm{Cs}^{-1}$ [140] em água com o mesmo perfil observado na Figura 17, apresentando áreas médias próximas a $70 \AA^{2}$ molécula $^{-1}$; similar ao valor obtido neste trabalho (Tabela 2). A presença dos íons $\mathrm{Ca}^{2+}$ na subfase não modifica significativamente o perfil da isoterma, comparando-se com aquela obtida em água pura.

Os valores de $\mathrm{CS}_{\mathrm{S}}^{-1}$ também são similares para todos os estágios de compactação, até uma área de $70 \AA^{2}$ molécula $^{-1}$ (Figura 17B). Para menores valores de área observase uma ligeira compressão da monocamada na subfase contendo $\mathrm{CaCl}_{2}$, bem como um deslocamento horizontal da curva de $\mathrm{CS}_{\mathrm{S}}^{-1}$, deslocando o máximo para menores áreas moleculares. Este efeito possivelmente decorre de uma diminuição da repulsão intereletrônica (das cabeças polares carregadas positivamente do DODAB) promovida pela adsorção dos íons $\mathrm{Cl}^{-}$na interface, próximo às cabeças polares positivas do lipídeo, pois fora verificado que a blindagem destes grupos positivamente carregados (e a 
consequente condensação da monocamada) ocorre na presença de contraíons e de maneira dependente da polarizabilidade deste [141].

Os parâmetros físico-químicos obtidos das isotermas de DODAB estão resumidos na Tabela 2. As áreas moleculares médias refletem a similaridade nas condições das monocamadas na ausência e presença do sal, com valores de 67 e $66 \AA^{2}$ molécula $^{-1}$, respectivamente. Porém, em contraste a esta similitude, foi observado um aumento não somente no $\mathrm{CS}_{\mathrm{S}}^{-1}$ máximo, mas também no $\mathrm{CS}_{\mathrm{S}}^{-1}$ obtido em $\pi=30 \mathrm{mN} \mathrm{m}^{-1}$ na presença de $\mathrm{CaCl}_{2}$, indicando maior rigidez da monocamada nesta condição. Tal valor de $\pi$ foi representado em destaque, pois é aquele utilizado posteriormente durante a confecção dos filmes LB.
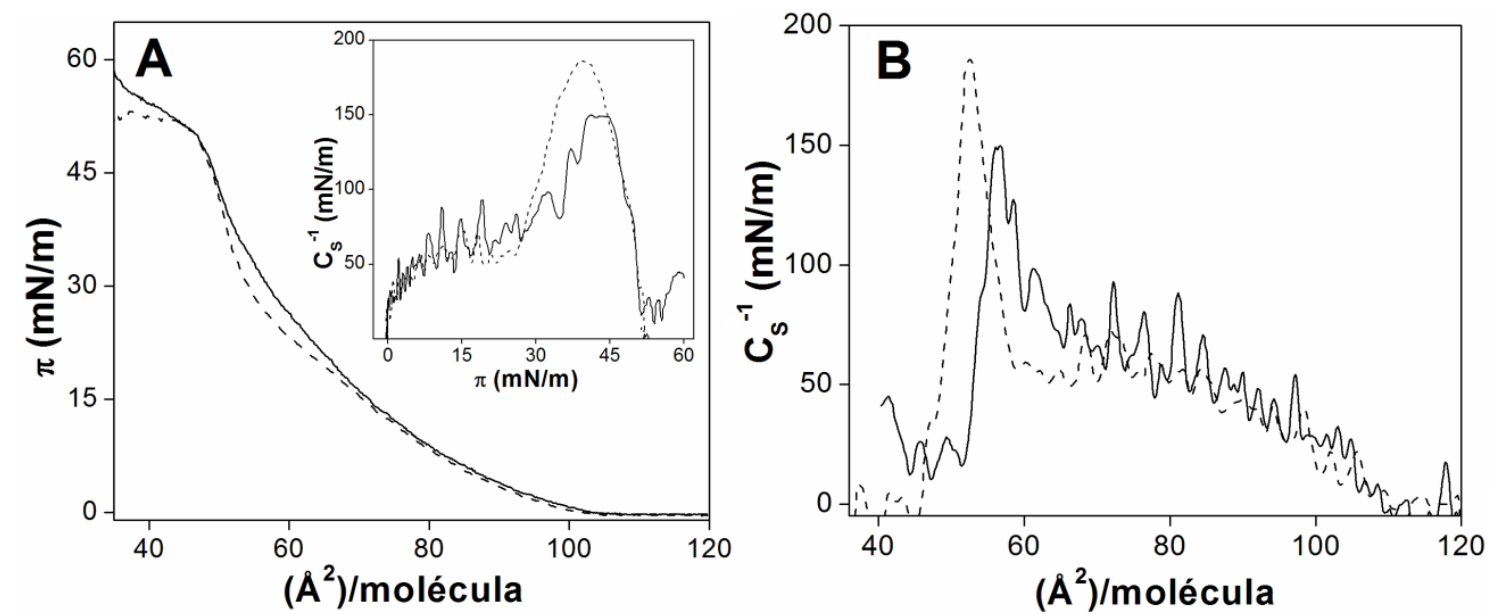

Figura 17 - Isotermas $\pi$-A (A) e valores de $\mathrm{CS}^{-1}$ em cada estágio de compressão (B) das monocamadas de DODAB obtidas em água pura (linha sólida) ou em $\mathrm{CaCl}_{2} 10 \mathrm{mmol} \mathrm{L}$ ${ }^{1}$ (linha tracejada). Inserção: $\mathrm{CS}^{-1}$ em função de $\pi$.

As isotermas $\pi$-A de DPPC estão representadas na Figura 18. Observa-se, em subfases contendo água pura, uma região de coexistência de fases LC-LE em valores de $\pi$ próximos a $10 \mathrm{mN} \mathrm{m}^{-1}$ (Figura 18A). Para menores áreas moleculares a partir deste platô, obtém-se um aumento exponencial da pressão em função da compressão, atingindo fases condensadas em áreas abaixo de $65 \AA^{2}$ molécula $^{-1}$. O colapso da monocamada ocorreu para $\pi$ acima de $60 \mathrm{mN} \mathrm{m}^{-1}$. Tais parâmetros estão de acordo com as isotermas reportadas na literatura por diferentes autores [75,142,143], que relatam platôs em torno de $\pi=9 \mathrm{mN} \mathrm{m}^{-1}$ e área mínima de $60 \AA^{2}$ molécula $^{-1}$ (a $20{ }^{\circ} \mathrm{C}$ ), com pressões de colapso sempre acima de $55 \mathrm{mN} \mathrm{m}^{-1}$. 

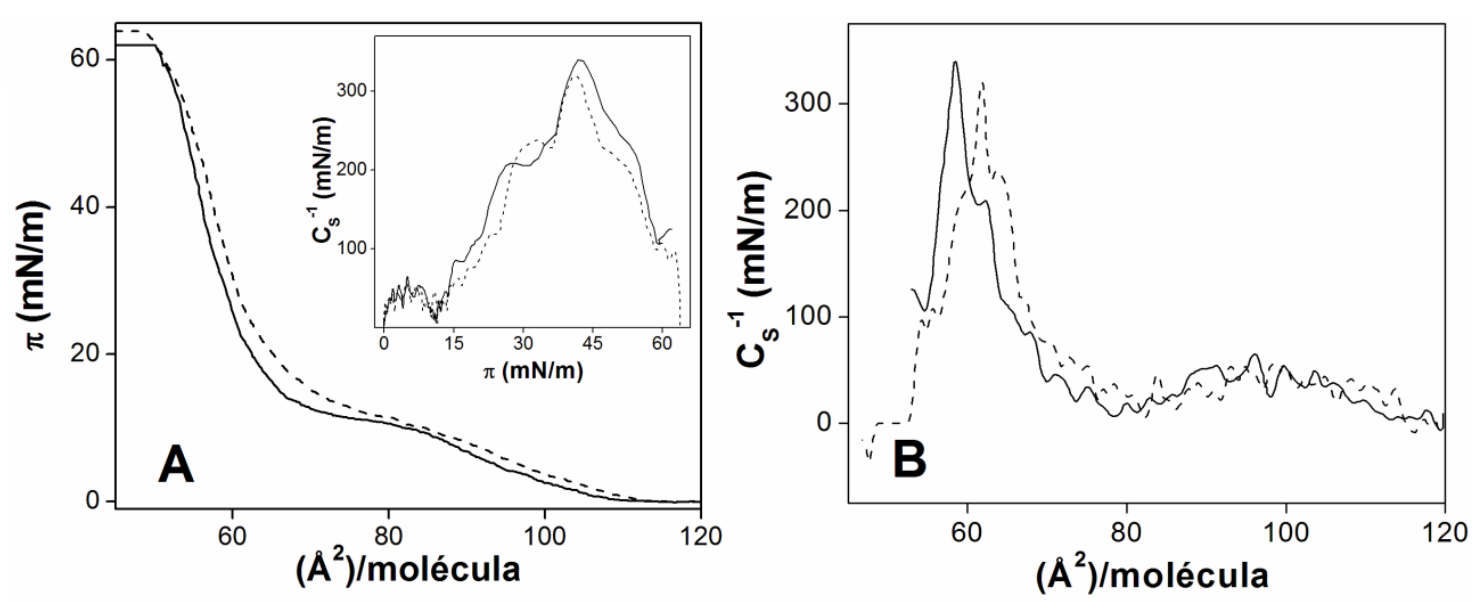

Figura 18 - Isotermas $\pi$-A (A) e valores de $\mathrm{CS}_{\mathrm{S}}^{-1}$ em cada estágio de compressão (B) das monocamadas de DPPC obtidas em água pura (linha sólida) ou em $\mathrm{CaCl}_{2} 10 \mathrm{mmol} \mathrm{L}{ }^{-1}$ (linha tracejada). Inserção: $\mathrm{CS}_{\mathrm{S}}^{-1}$ em função da pressão de superfície.

A isoterma obtida na subfase contendo $\mathrm{CaCl}_{2}$ apresenta o mesmo perfil (sem extinção do platô característico da isoterma de DPPC) porém mais deslocada horizontalmente para a direita; uma expansão da monocamada na presença do sal. Na presença deste sal foram obtidos valores de áreas moleculares em magnitudes de 3,9 e 1,6 $\AA^{2}$ molécula $^{-1}$ maiores que na subfase de água pura, nas pressões de $\pi=15$ e $25 \mathrm{mN}$ $\mathrm{m}^{-1}$ respectivamente.

O DPPC apresenta carga líquida nula em água pura. Porém, a presença de uma subfase salina provoca um desbalanceamento de carga, através da adsorção preferencial de íons aos grupos polares (orientados para a subfase) deste lipídeo. Isto justifica a expansão da isoterma na subfase de $\mathrm{CaCl}_{2}$ : por conter os grupos fosfato e colina em sua cabeça polar, o DPPC comporta-se de maneira análoga ao que fora observado para micelas zwitteriônicas, cujo potencial de superfície torna-se negativo devido à adsorção de ânions a um grupo positivo da superfície interna micelar [144].

Esta tênue expansão da isoterma na presença de $\mathrm{CaCl}_{2}$ corrobora precisamente com os valores relatados na literatura [145,146], que os atribui a uma adsorção preferencial de íons $\mathrm{Ca}^{2+}$ aos grupos polares do DPPC (o raio e área deste íon correspondem a $1,14 \AA$ e $4 \AA^{2}$, respectivamente).

Os parâmetros físico-químicos das isotermas de DPPC estão resumidos também na Tabela 2. Novamente, foram obtidos valores similares de áreas moleculares médias na presença e ausência de sal, além de maior rigidez da monocamada em $\pi=30 \mathrm{mN} \mathrm{m}^{-1}$ na presença de $\mathrm{CaCl}_{2}$, refletida no maior valor de $\mathrm{C}_{\mathrm{S}}{ }^{-1}$. A presença deste sal diminuiu ligeiramente o valor de $\mathrm{Cs}^{-1}$ máx em relação àquele obtido em água pura, indicando uma 
monocamada mais fluida na presença de $\mathrm{CaCl}_{2}$. Isto somado à expansão da monocamada reforça o argumento de que a presença deste sal desfavorece a interação entre as moléculas de DPPC na monocamada.

As isotermas $\pi$-A de DMPA estão representadas na Figura 19. O perfil da isoterma em água pura apresenta uma região de coexistência de fases LC-LE com valores de $\pi$ próximos a $5 \mathrm{mN} \mathrm{m}^{-1}$, seguido de um aumento exponencial da $\pi$ (de maneira análoga ao DPPC). Ainda nestas condições, as fases condensadas ocorrem em áreas menores que $60 \AA^{2}$ molécula $^{-1}$, com um valor de área média próximo a $60 \AA^{2}$ molécula ${ }^{-1}$.
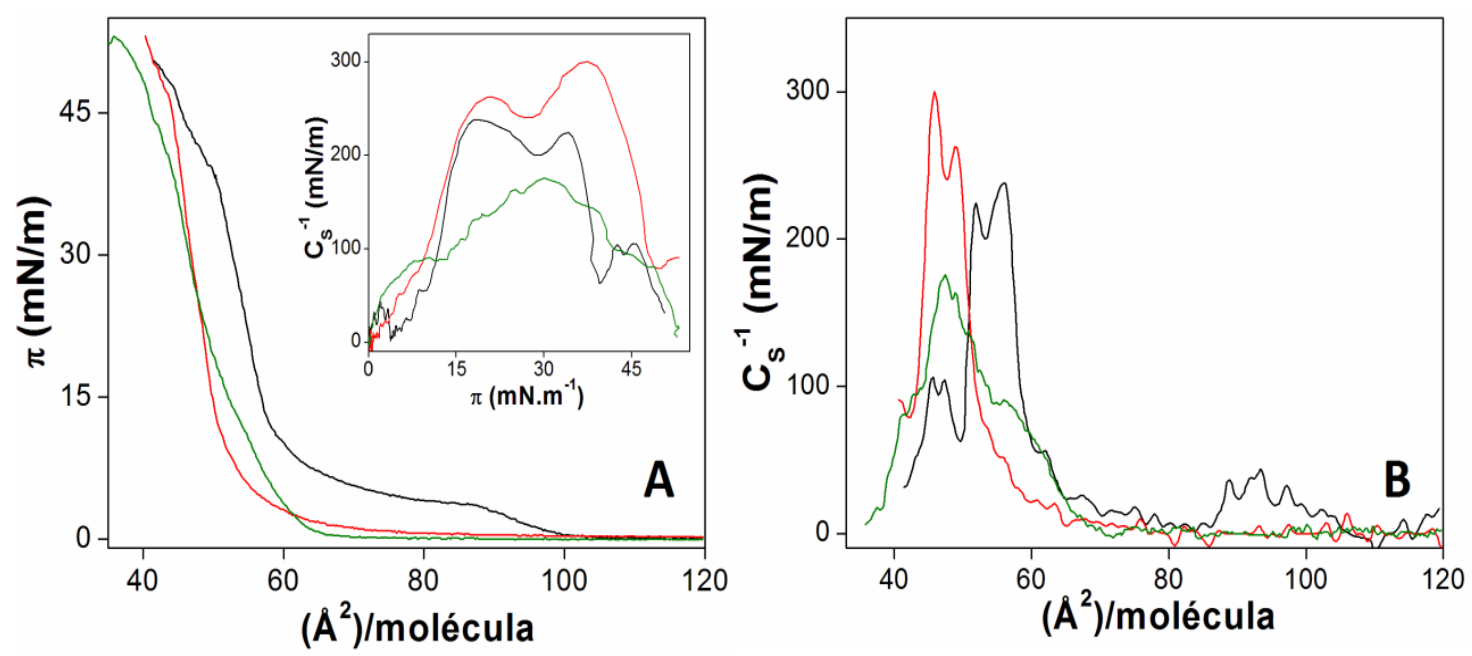

Figura 19 - Isotermas $\pi$-A (A) e valores de $\mathrm{CS}^{-1}$ em cada estágio de compressão (B) das monocamadas de DMPA obtidas em água pura (preto), $\mathrm{CaCl}_{2} 0,1 \mathrm{mmol} \mathrm{L}^{-1}$ (vermelho) e $\mathrm{CaCl}_{2} 70 \mathrm{mmol} \mathrm{L}{ }^{-1}$ (verde). Inserção: $\mathrm{CS}^{-1}$ em função de $\pi$.

De uma maneira geral, o perfil desta isoterma apresenta concordância com outras obtidas (também em água pura) na literatura [147,148], cujos platôs ocorrem para $\pi$ próximos a $4 \mathrm{mN} \mathrm{m}^{-1}$. Porém, estes autores relataram áreas médias cerca de $15 \AA^{2}$ molécula $^{-1}$ menores em relação àquela obtida na Figura 19, devido um posicionamento do início do aumento da $\pi$ a partir de áreas moleculares menores (em torno de 80 e 100 $\AA^{2}$ molécula $^{-1}$ para as isotermas da literatura e aquela representada neste trabalho, respectivamente).

$\mathrm{Na}$ análise do efeito de $\mathrm{CaCl}_{2}$ nas monocamadas de DMPA, foram utilizadas duas condições de força iônica, uma vez que, segundo a literatura [106], baixas concentrações de sais contendo cátions divalentes já provocam efeitos de compressão significativos nas monocamadas deste lipídeo. 
Em subfases diluídas $\left(0,1 \mathrm{mmol} \mathrm{L}{ }^{-1}\right)$ ou concentradas $(70 \mathrm{mmol} \mathrm{L}-1)$ de $\mathrm{CaCl}_{2}$, verifica-se uma drástica modificação na organização da monocamada, com uma compressão para menores valores de áreas necessárias para um aumento de $\pi$, além de uma extinção da região de coexistência de fases (Figura 19A). Este efeito compressivo em monocamadas de DMPA fora observado por diferentes autores, tanto para sais de $\mathrm{Ca}^{2+}$ [149], quanto para de outros cátions divalentes [106,150]. Além disto, foi verificando que o aumento da força iônica induzido por um sal de $\mathrm{Ca}^{2+}$ provoca aumento das dimensões e uma compactação das micelas de um lipídeo aniônico [151].

A adsorção preferencial de cátions divalentes aos grupos fosfato em monocamadas de DMPA foi demonstrada por abordagens computacionais [152], comprovando uma inversão de cargas, com consequente diminuição do módulo da carga líquida superficial. Outros trabalhos confirmaram empiricamente uma acumulação de íons $\mathrm{Ca}^{2+}$ na interface desta monocamada, em uma proporção próxima de DMPA:Ca ${ }^{2+}$ 1:2 [149]. Portanto, a compressão da isoterma observada na Figura 19 ocorreu possivelmente devido uma diminuição da repulsão eletrostática das cabeças polares do DMPA, graças à adsorção de $\mathrm{Ca}^{2+}$ aos grupos fosfatos negativamente carregados.

Tabela 2 - Módulos compressionais em $\pi=30 \mathrm{mN} \mathrm{m}^{-1}$ e área molecular média para as monocamadas de Langmuir em diferentes subfases

\begin{tabular}{cccc}
\hline Monocamada & Subfase & $\begin{array}{c}\mathrm{Cs}^{-1} \\
\left(\mathrm{mN} \mathrm{m}^{-1}\right)\end{array}$ & $\begin{array}{c}\text { Área Média } \\
\left(\AA^{2} \text { molécula }^{-1}\right)\end{array}$ \\
\hline DODAB & $\mathrm{H}_{2} \mathrm{O}$ & $85 \pm 4$ & $67 \pm 3$ \\
& $\mathrm{CaCl}_{2} 10 \mathrm{mmol} \mathrm{L}^{-1}$ & $101 \pm 5$ & $66 \pm 3$ \\
DPPC & $\mathrm{H}_{2} \mathrm{O}$ & $206 \pm 10$ & $66 \pm 3$ \\
& $\mathrm{CaCl}_{2} 10 \mathrm{mmol} \mathrm{L}^{-1}$ & $229 \pm 11$ & $68 \pm 3$ \\
DMPA & $\mathrm{H}_{2} \mathrm{O}$ & $203 \pm 10$ & $61 \pm 3$ \\
& $\mathrm{CaCl}_{2} 0,1 \mathrm{mmol} \mathrm{L}^{-1}$ & $260 \pm 13$ & $53 \pm 3$ \\
& $\mathrm{CaCl}_{2} 70 \mathrm{mmol} \mathrm{L}^{-1}$ & $173 \pm 10$ & $56 \pm 1$ \\
\hline
\end{tabular}

Um aumento mais pronunciado de rigidez das monocamadas foi observado na subfase mais diluída (Inserção da Figura 19A). Observando-se os parâmetros das isotermas de DMPA representados na Tabela 2, verifica-se o efeito de compressão das monocamadas evidenciados pelos menores valores de áreas médias na presença de 
$\mathrm{CaCl}_{2}$, além de modificações nos valores de $\mathrm{CS}^{-1}$ em $\pi=30 \mathrm{mN} \mathrm{m}^{-1}$ para as condições de força iônica variada.

Considerando a condição de menor força iônica, dentre os três lipídeos estudados, o DMPA sofre maiores alterações na estrutura da monocamada na presença de $\mathrm{CaCl}_{2}$ na subfase, como já esperado devido à sua carga negativa, apresentando não só uma compressão significativa como também o maior aumento no valor de $\mathrm{CS}_{\mathrm{S}}{ }^{-1}$. O valor de $\pi$ a partir do qual obtém-se $\mathrm{CS}_{\mathrm{S}}^{-1}$ maior que $100 \mathrm{mN} \mathrm{m}^{-1}$ (fase condensada) na presença de $\mathrm{CaCl}_{2}$, ocorre em torno de 29, 21 e $9 \mathrm{mN} \mathrm{m}^{-1}$ (correspondendo a 56, 67 e 52 $\AA^{2}$ molécula $^{-1}$ ) para o DODAB, DPPC e DMPA, respectivamente. Estes parâmetros evidenciam as diferenças na organização interfacial de lipídeos com diferentes cargas superficiais, o que possibilita a formação de matrizes biomiméticas com estruturas e cargas variadas, buscando-se os melhores parâmetros para a aplicação final desejada.

A fim de avaliar se há uma modificação de incorporação da TNAP na monocamada de DMPA em função de sua fluidez, sistemas binários deste lipídeo com diferentes frações molares de colesterol foram escolhidos; o papel deste apenas como modulador do $\mathrm{Cs}^{-1}$ da monocamada resultante do sistema misto. $\mathrm{O}$ efeito de colesterol na matriz fosfolipídica de DMPA em diferentes proporções está representado na Figura 20.

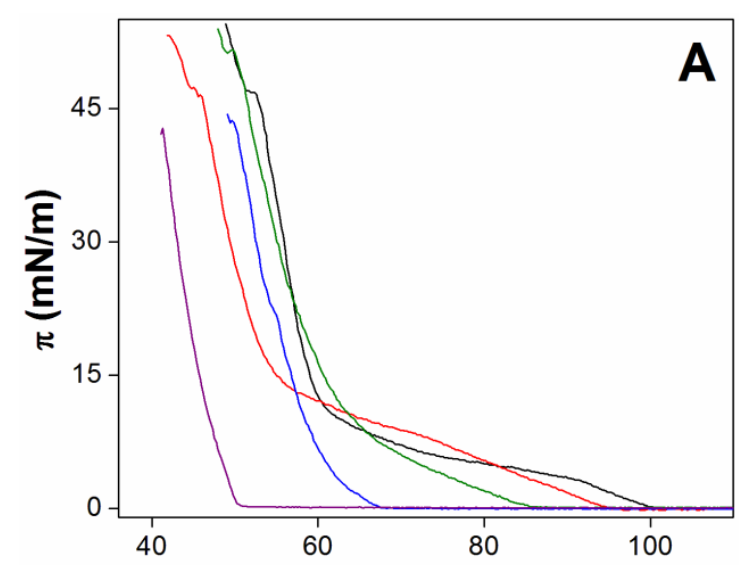

$\left(\AA^{2}\right) /$ molécula

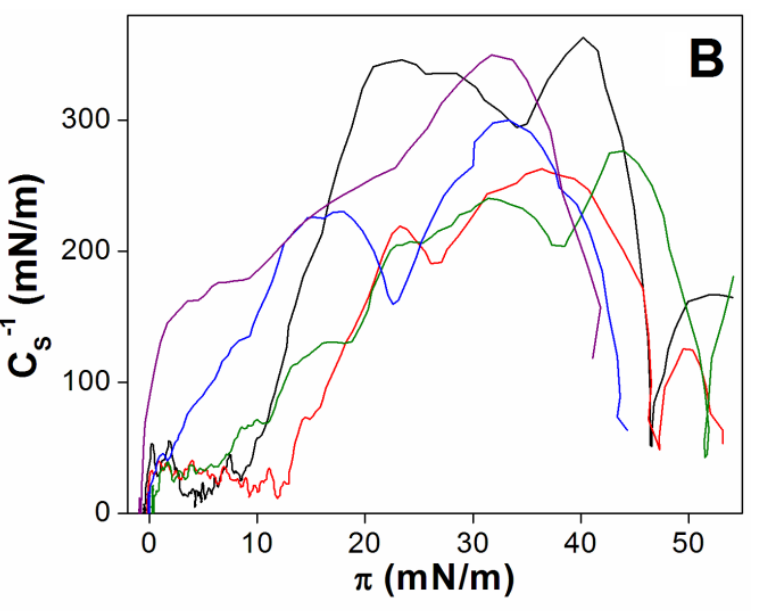

Figura 20 - Isotermas $\pi$-A (A) e valores de $\mathrm{CS}^{-1}$ em cada estágio de compressão (B) das monocamadas de DMPA:Chol obtidas em água pura nas proporções de 1:0 (preto), 4:1 (vermelho), 1:1 (verde), 1:4 (azul) e púrpura (0:1).

Verifica-se que o aumento da quantidade deste esterol na monocamada provoca uma perda progressiva das regiões de coexistência de fases; como já verificado para lipídeos contendo duas cadeias hidrocarbônicas longas [153]. Na proporção de 4:1 
verifica-se que a monocamada torna-se mais fluida (diminuição dos valores de $\mathrm{CS}_{\mathrm{S}}{ }^{-1}$ ), com um aumento da rigidez com o aumento da quantidade de colesterol na matriz (aumento dos valores de $\mathrm{Cs}^{-1}$ com a diminuição da razão DMPA:Chol); uma vez que a monocamada de colesterol é mais rígida que a de DMPA isoladamente em todo o intervalo de $\pi$ (Figura 20B).

\subsection{Caracterização dos filmes $L B$ dos lipídeos}

Após a caracterização das monocamadas dos lipídeos em diferentes subfases, foram confeccionados os filmes LB dos mesmos sobre um cristal de quartzo recoberto com ouro a $\pi$ constante e igual a $30 \mathrm{mN} \mathrm{m}^{-1}$. Os valores de massa do filme de DODAB em função do número de camadas estão representados graficamente na Figura 21.

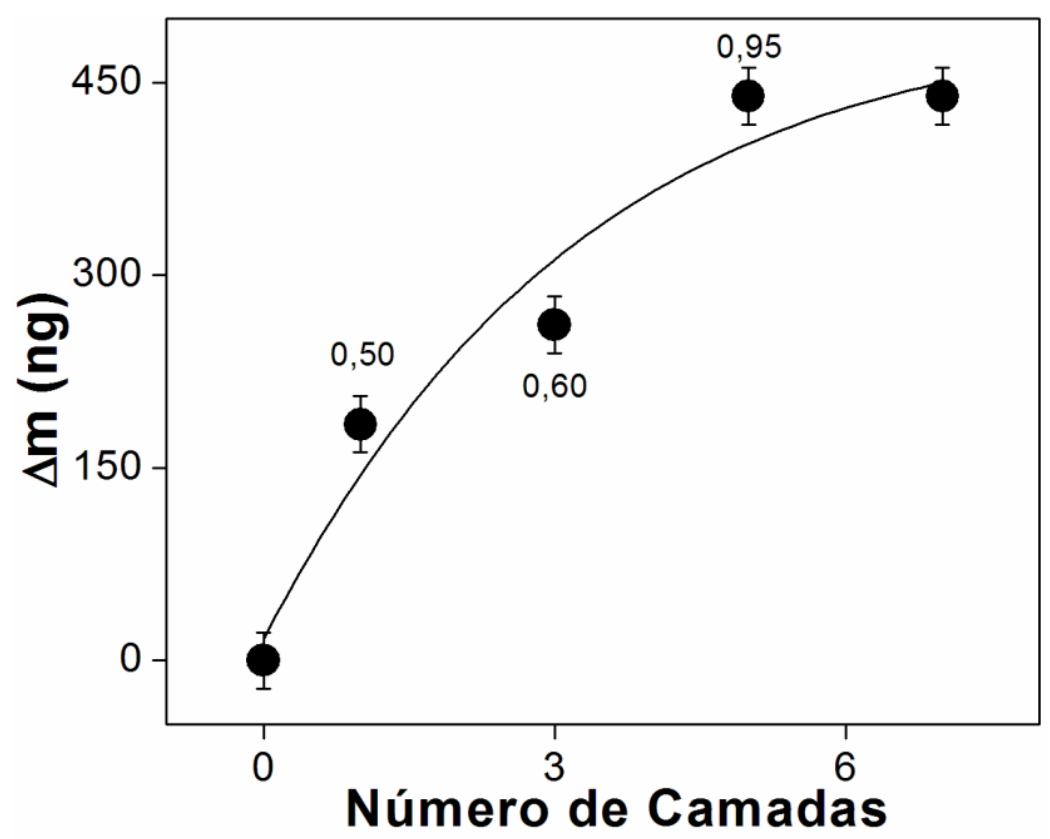

Figura 21 - Massas de DODAB depositado sobre cristal de quartzo recoberto com ouro em função do número de camadas, a partir de uma subfase de água pura. Os números sobre os pontos representam a razão de transferência de cada deposição.

Os valores sobre os pontos correspondem às razões de transferência ( $\left.R_{\text {trans }}\right)$. Observa-se uma dependência linear até a quinta camada, a partir da qual não é mais possível a deposição de camadas. Os valores de $\mathrm{R}_{\text {trans }}$ da região linear (até a quinta camada) indicam que a deposição das 3 primeiras camadas não foi eficiente, enquanto que as demais foram. A deposição da $7^{\circ}$ camada não provocou aumento da massa do cristal, sendo, portanto, ineficiente. 
Os valores de massa de DPPC em função do número de camadas depositadas estão representados graficamente na Figura 22. Em água, observa-se linearidade até a $5^{\circ}$ camada, a partir da qual não fora mais observado deposição do lipídeo. Verifica-se ainda que os valores de $\mathrm{R}_{\text {trans }}$ aumentam cada vez mais da $1^{\circ}$ até a $5^{\circ}$ camada, indicando que a eficiência é máxima na deposição da $1^{\circ}$ camada ( $\mathrm{R}_{\text {trans }}$ próximo da unidade).

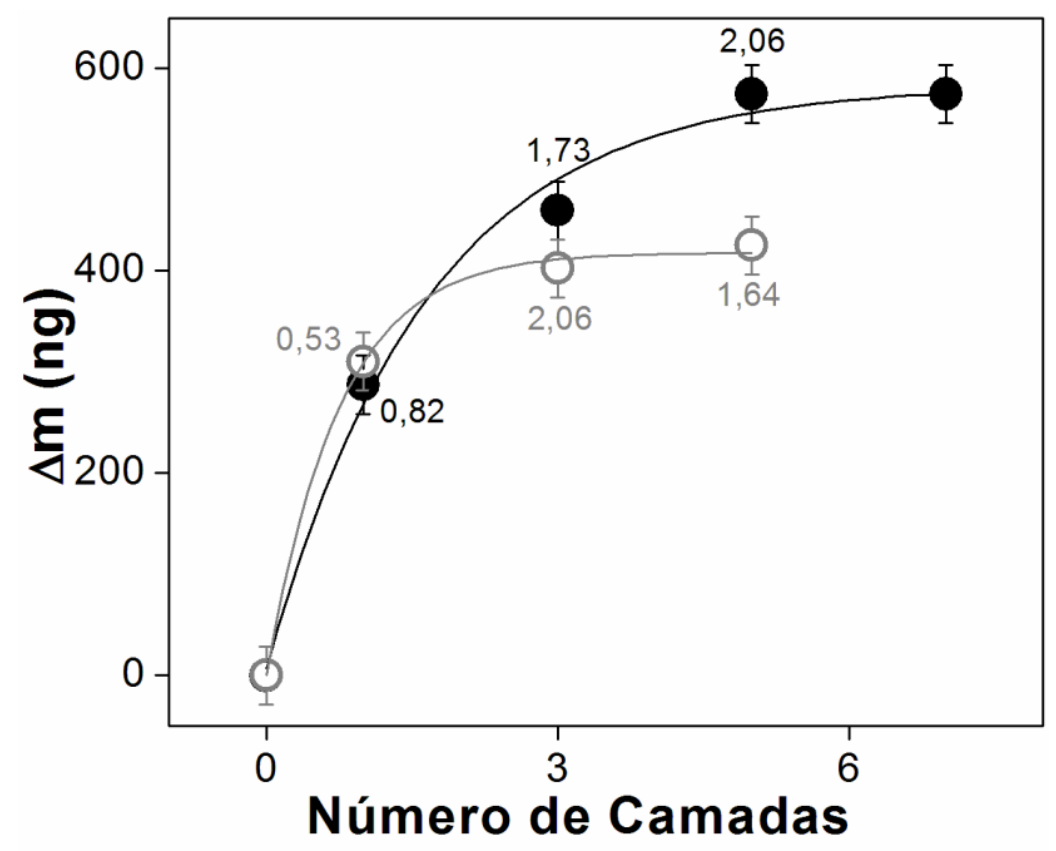

Figura 22 - Massas de DPPC depositado sobre cristal de quartzo recoberto com ouro em função do número de camadas, a partir de uma subfase de água pura (•) ou de $\mathrm{CaCl}_{2}$ $10 \mathrm{mmol} \mathrm{L}^{-1}(\circ)$. Os números sobre os pontos representam a razão de transferência de cada deposição.

Mesmo a taxa de transferência da região linear em subfase contendo $\mathrm{CaCl}_{2}$ sendo maior que aquela obtida em água pura (Tabela 3), a deposição é desfavorecida em cada camada na presença do sal. Ainda em subfase salina, observa-se uma saturação de massa a partir da $3^{\circ}$ camada (ponto até o qual os valores seguem um comportamento linear), com valores de $\mathrm{R}_{\text {trans }}$ indicando apenas transferências ineficientes. Isto corrobora com o efeito que este sal provoca na monocamada de DPPC, desfavorecendo as interações do tipo cabeça polar-cabeça polar (devido um desbalanceamento de carga na adsorção preferencial de íons $\mathrm{Ca}^{2+}$ ). Este fato justifica o aumento insignificante de massa da $2^{\mathrm{a}}$ para a $3^{\mathrm{a}}$ camada do filme de DPPC a partir da subfase de $\mathrm{CaCl}_{2}$ (Figura 22).

Os valores de massa de DMPA em função do número de camadas estão representados graficamente na Figura 23. Em subfase constituída de água pura, 
observa-se um perfil de saturação de massa com o aumento do número de camadas, uma vez que a curva resultante é uma hipérbole. Os valores de $\mathrm{R}_{\text {trans }}$ são crescentes, indicando que a cada deposição a transferência vai tornando-se menos eficiente (distanciamento do valor unitário de $\mathrm{R}_{\text {trans). }}$ ).

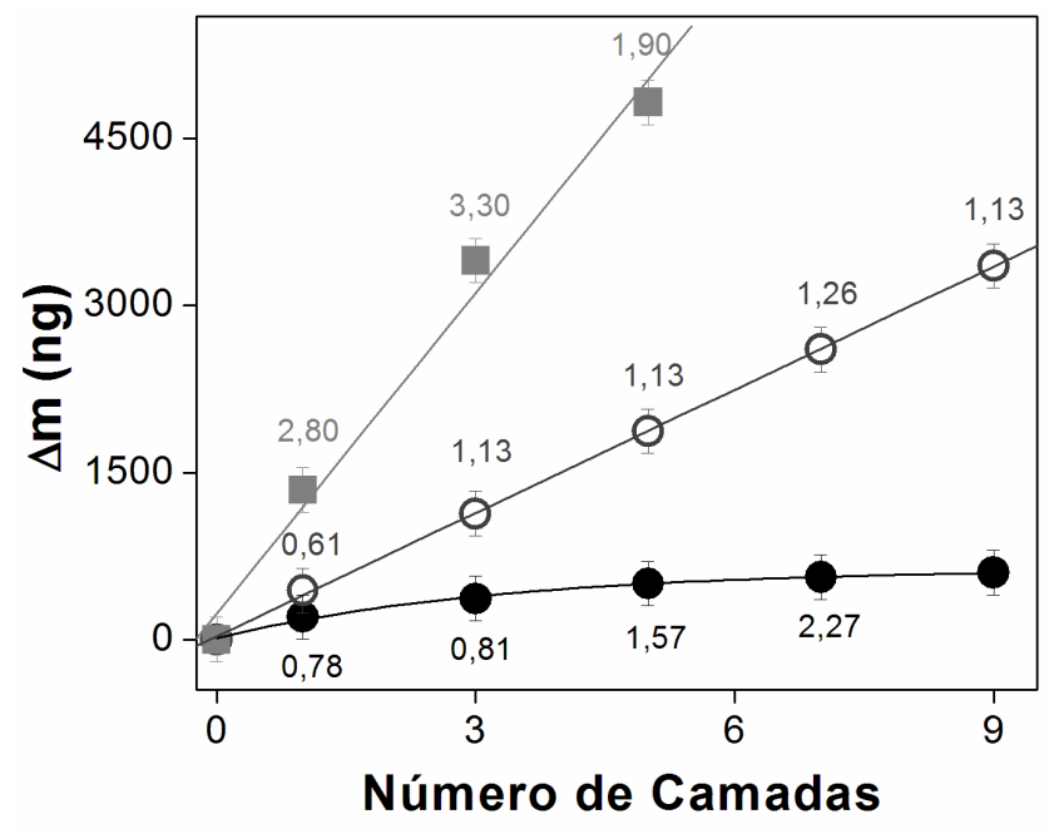

Figura 23 - Massas de DMPA depositado sobre cristal de quartzo recoberto com ouro em função do número de camadas, a partir de uma subfase de água pura (•), $\mathrm{CaCl}_{2} 0,1$ mmol L $\mathrm{L}^{-1}(\circ)$ e $70 \mathrm{mmol} \mathrm{L}^{-1}(\square)$. Os números sobre os pontos representam a razão de cada deposição.

A ordem de grandeza das massas do filme em água pura é cerca de 4 e 10 vezes menor em relação àquelas obtidas em subfases contendo $\mathrm{CaCl}_{2} 0,1$ e $70 \mathrm{mmol} \mathrm{L}^{-1}$, respectivamente (Tabela 3). Como a adsorção preferencial de íons $\mathrm{Ca}^{2+}$ promoveu diminuição da repulsão intereletrônica na monocamada de DMPA, a presença destes íons provocou um "efeito ponte" entre as cabeças polares negativas deste lipídeo (ausente em subfase de água pura, justificando a saturação de deposição). Desta forma, a presença deste sal na subfase provocou uma otimização na deposição do filme LB (linearidade observada na Figura 23), bem como a transferência de uma maior quantidade de DMPA (ou aumento da co-adsorção de íons e/ou água ao filme).

Em subfase de $\mathrm{CaCl}_{2}$ mais diluída apresentou não apenas linearidade da massa em função do número de camadas, como também valores de $\mathrm{R}_{\text {trans }}$ mais próximos à unidade. Desta forma, todas as transferências foram eficientes e otimizadas frente 
àquelas em água pura (de acordo com o aumento do $\mathrm{CS}^{-1}$ na pressão de deposição da monocamada de DMPA - Figura 19).

Em uma solução mais concentrada deste sal também foi obtido um comportamento linear entre a massa e o número de camadas do filme, com a maior taxa de transferência dentre todas as condições adotadas (Tabela 3). Porém, os valores de $\mathrm{R}_{\text {trans }}$ indicaram transferências ineficientes. Apesar da monocamada de DMPA nesta subfase ser mais fluida que aquela obtida em água pura (Tabela 3), ainda há um efeito compressor induzido pelo sal na cabeça polar (Figura 19A); explicando a condição de deposição linear com maior taxa de transferência. A otimização do recobrimento de um suporte sólido com o aumento da força iônica é um fenômeno já descrito na literatura [123].

É possível estimar a massa por cada camada de lipídeo transferida, calculando o número esperado de moléculas de lipídeo transferidos ao cristal de quartzo a partir da área mínima (considerando uma cobertura total da área com ouro, cujo valor é 0,662 $\mathrm{cm}^{2}$ ) [121]. Tais estimativas estão representadas como "taxa teórica" na Tabela 3.

Tabela 3 - Taxas de transferência de massa dos filmes LB dos lipídeos em função do número de camadas, obtidos em diferentes condições

\begin{tabular}{cccc}
\hline Filme & Subfase & $\begin{array}{c}\text { Taxa de Transferência } \\
(\text { ng camada }\end{array}$ & $\begin{array}{c}\text { Taxa Teórica } \\
\left(\text { ng camada }^{-1}\right)\end{array}$ \\
\hline DODAB & $\mathrm{H}_{2} \mathrm{O}$ & $79 \pm 14$ & 103 \\
DPPC & $\mathrm{H}_{2} \mathrm{O}$ & $106 \pm 26$ & 122 \\
& $\mathrm{CaCl}_{2} 10 \mathrm{mmol} \mathrm{L}^{-1}$ & $121 \pm 65$ & $126^{*}$ \\
\hline DMPA & $\mathrm{H}_{2} \mathrm{O}$ & $95 \pm 15$ & 109 \\
& $\mathrm{CaCl}_{2} 0,1 \mathrm{mmol} \mathrm{L}^{-1}$ & $369 \pm 25$ & - \\
& $\mathrm{CaCl}_{2} 70 \mathrm{mmol} \mathrm{L}^{-1}$ & $959 \pm 52$ & - \\
\hline & & &
\end{tabular}

Observa-se similaridade entre os valores esperados com os valores obtidos experimentalmente (considerando os desvios atribuídos a cada valor), indicando que as transferências ocorreram com regimes de uma monocamada por ciclo de imersãoemersão. Foi considerada uma razão 2:1 de lipídeo/íon na estimativa da taxa teórica do filme de DPPC/Ca ${ }^{2}$; proporção esta considerada a partir da expansão de área $\left(2 \AA^{2}\right.$ 
molécula ${ }^{-1}$, metade da área de um íon $\mathrm{Ca}^{2+}$ ) para a isoterma de DPPC na presença de $\mathrm{CaCl}_{2}\left(\mathrm{a} \pi>25 \mathrm{mN} \mathrm{m}^{-1}\right.$, uma vez que o filme fora depositado a $\left.30 \mathrm{mN} \mathrm{m}^{-1}\right)$.

Observa-se, a partir das taxas teóricas obtidas, que a adsorção específica de um determinado íon provoca uma modificação menor que 5\% na massa do filme LB. Desta forma, a diferença significativa nas taxas de transferência do DMPA surge majoritariamente de uma transferência mais expressiva de lipídeo com o aumento da força iônica.

Dentre os três lipídeos, aquele que apresenta melhores condições de deposição em subfases contendo $\mathrm{CaCl}_{2}$, tanto em baixas quanto em altas concentrações, é o DMPA; tendo em vista que este apresenta linearidade entre a massa e o número de camadas e também monocamada mais rígida na presença do sal. $\mathrm{O}$ gráfico da Figura 24 sumariza estes resultados.

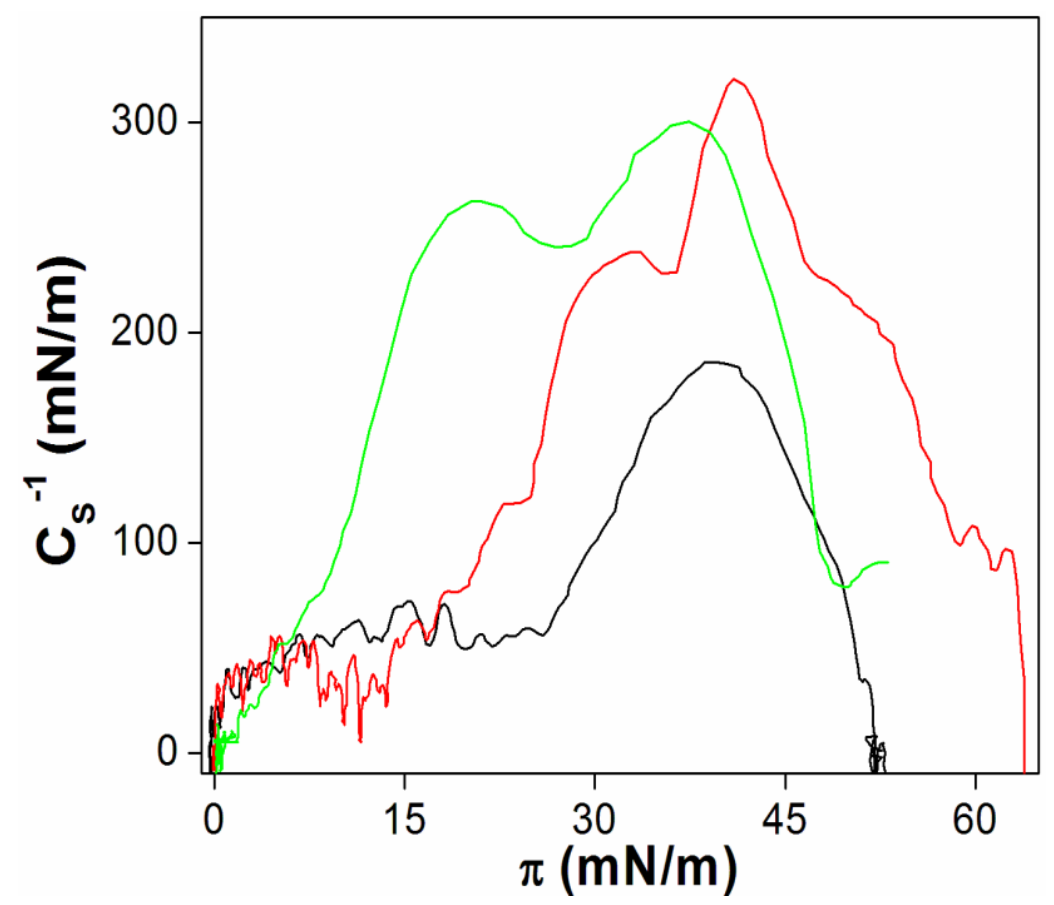

Figura 24 - Módulos compressionais em função da pressão de superfície das monocamadas de DODAB (preto), DPPC (vermelho) em $\mathrm{CaCl}_{2} 10 \mathrm{mmol} \mathrm{L}^{-1}$ e DMPA (verde) em $\mathrm{CaCl}_{2}$ 0,1 mmol L-1.

Observa-se que a monocamada de DMPA é aquela que apresenta um menor valor de $\pi$ necessário para alcançar fases condensadas (com $\mathrm{CS}_{\mathrm{S}}^{-1}$ acima de $100 \mathrm{mN} \mathrm{m}^{-1}$ ), além de apresentar a maior rigidez na pressão de deposição em subfase contendo $\mathrm{CaCl}_{2}$.

Nota-se que na deposição da $1^{\circ}$ camada, em todas as circunstâncias relatadas anteriormente, foram obtidos valores de $\mathrm{R}_{\text {trans }}$ indicando transferências ineficientes; ora 
abaixo e ora acima da unidade. A ineficiência da primeira transferência é um fenômeno esperado, uma vez que a $1^{\circ}$ camada formada sobre o suporte sólido sofre efeitos de irregularidades da superfície deste [118], tornando geralmente a compensação de área da monocamada maior que a área total onde é depositado o filme. As posteriores deposições sobre a superfície já modificada ocorram homogeneamente.

\subsection{Caracterização da Atividade Superficial e das Monocamadas em presença de TNAP}

A fim de promover a co-adsorção em uma monocamada de lipídeo, faz-se necessária uma condição na qual a TNAP seja capaz de migrar até a interface líquido-ar na ausência do detergente não-iônico utilizado na solubilização da enzima; visando caracterizar a interação direta desta com os lipídeos, sem a possível interferência de um detergente.

Antes de obter uma condição que favoreça a migração da enzima para a interface líquido-ar é necessária uma análise comparativa entre a atividade superficial desta na ausência e na presença de polidocanol. Tais atividades estão representadas na Figura 25. Verifica-se que em uma gota pendente de água pura há um aumento de $\pi$ pós-adição de uma quantidade de TNAP (Figura 25A), de maior magnitude na presença do detergente não-iônico. Foi obtido um aumento exponencial de $\pi$ com a compressão da interface contendo a enzima solubilizada na presença do detergente (Figura 25B); similarmente a isotermas $\pi$-A já descritas para TNAP solubilizada por polidocanol [68], cujos valores de $\pi$ não ultrapassaram $10 \mathrm{mN} \mathrm{m}^{-1}$.

Esta menor migração de TNAP para a interface na ausência de polidocanol corrobora com a ausência de atividade superficial da enzima isolada em uma cuba de Langmuir, para qualquer estágio de compressão (Figura 25B). É importante ressaltar que, na ausência do detergente, apesar de não haver um aumento de $\pi$ pós-espalhamento e compressão lateral de TNAP na subfase de uma cuba, houve um aumento após a injeção desta em uma gota de água; não somente devido uma maior razão área/volume neste sistema, como também devido uma maior concentração final de enzima neste microambiente. 

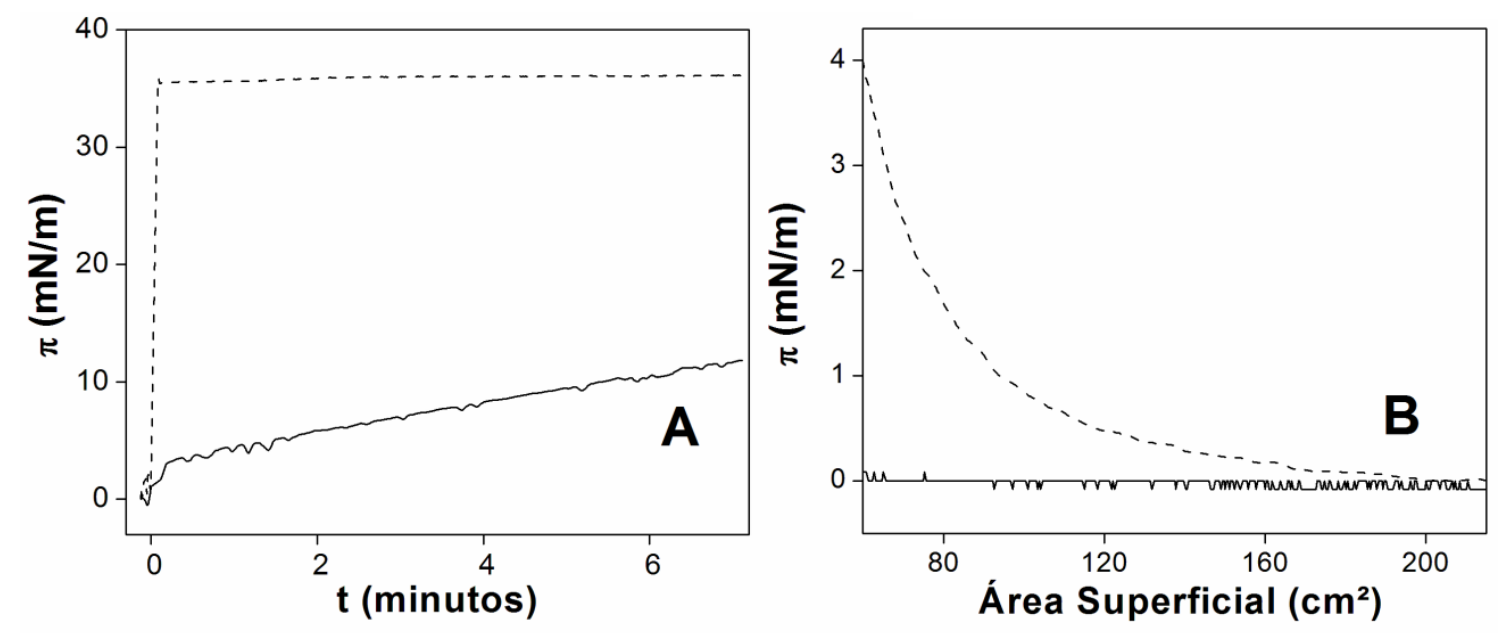

Figura 25 - Variação de $\pi$ em uma gota de água pós-injeção de 8,5 ng de TNAP (A) e isotermas $\pi$-A obtidas pós-espalhamento de 375 ng de TNAP em cuba de Langmuir em água pura (B), na ausência (linha sólida) e presença (linha tracejada) de polidocanol 1\% $\mathrm{p} / \mathrm{V}$.

Uma possível condição na qual a enzima hidrossolúvel migre para a interface líquido-ar, baseia-se no uso de soluções com forças iônicas moderadas. Desta forma, foi adotada uma condição [90] que favorece a atividade interfacial da TNAP, por meio do uso de uma subfase contendo $\mathrm{NaCl} 150 \mathrm{mmol} \mathrm{L}^{-1}$, a fim de averiguar a atividade superficial da enzima na ausência de polidocanol. Os resultados estão mostrados na isoterma $\pi$-A da Figura 26.
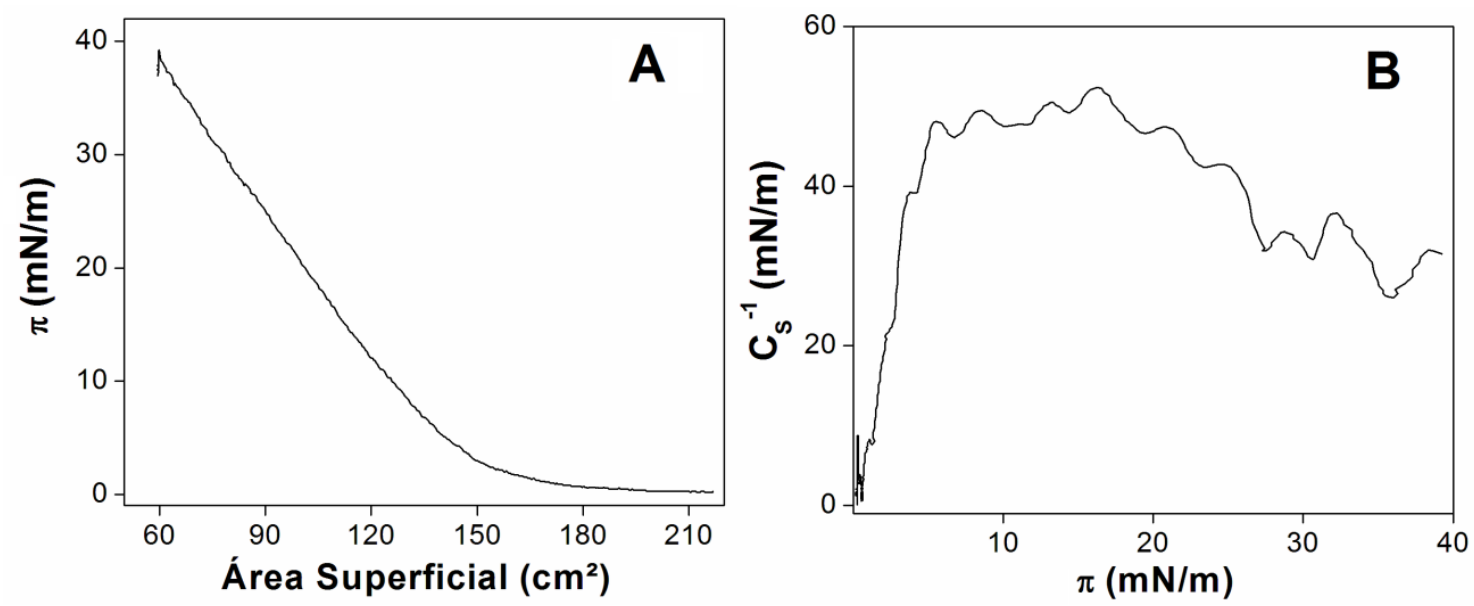

Figura 26 - Isoterma $\pi-\mathrm{A}$ de $18 \mu \mathrm{g}$ de TNAP na ausência de polidocanol espalhada sobre tampão Tris-HCl $10 \mathrm{mmol} \mathrm{L}^{-1} \mathrm{pH} 8,5$ contendo $\mathrm{NaCl} 150 \mathrm{mmol} \mathrm{L}^{-1}$ e $\mathrm{MgCl}_{2} 20$ mmol L $\mathrm{L}^{-1}(\mathrm{~A})$ e valores de $\mathrm{CS}_{\mathrm{S}}^{-1}$ em função de $\pi(\mathrm{B})$.

Observa-se um aumento significativo da atividade superficial da enzima em solução de força iônica próxima a $210 \mathrm{mmol} \mathrm{L}^{-1}$, com um aumento exponencial de $\pi \mathrm{em}$ 
função da diminuição da área superficial (Figura 26A); indicando a presença da enzima na interface, responsável pela diminuição da tensão superficial cada vez maior com a compactação da interface.

Esta monocamada de TNAP não apresentou fases condensadas, uma vez que os valores de $\mathrm{CS}^{-1}$ não excederam $50 \mathrm{mN} \mathrm{m}^{-1}$ (Figura 26B), em concordância com resultados obtidos em força iônica próxima de $400 \mathrm{mmol} \mathrm{L}^{-1}$ [68]; indicando que nestas condições (somente enzima na interface induzida por salting out) não seria viável a confecção de filmes LB com a enzima pura.

Como as forças iônicas moderadas induzem uma maior atividade superficial da TNAP na ausência do detergente não-iônico, faz-se necessário averiguar a possibilidade do uso de soluções de $\mathrm{CaCl}_{2}$ como subfases, uma vez que a co-adsorção da enzima com lipídeos na interface é de vital importância para sua posterior imobilização em filmes LB; visando ainda a presença de íons $\mathrm{Ca}^{2+}$ nestes para posteriores ensaios de mineralização. As isotermas de TNAP em soluções de diferentes forças iônicas induzidas por $\mathrm{CaCl}_{2}$ estão representadas na Figura 27.
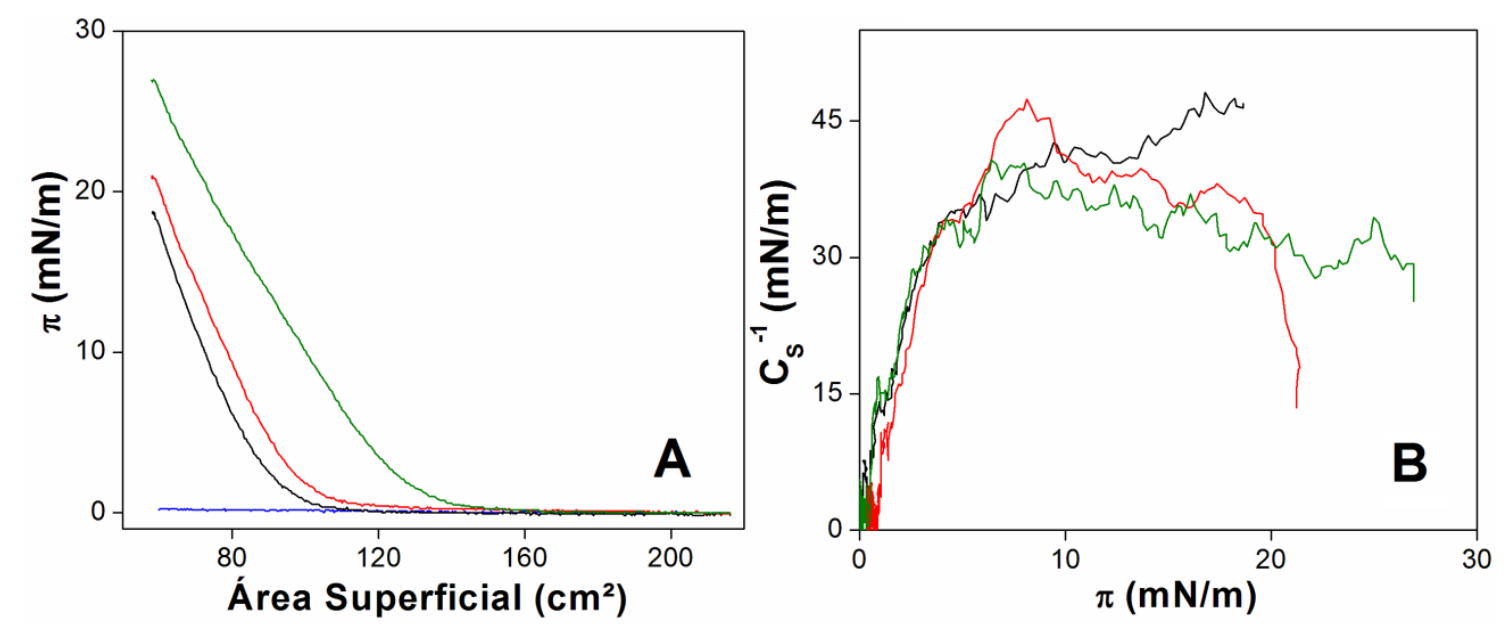

Figura 27 - Isotermas $\pi$-A (A) de 5,7 $\mu \mathrm{g}$ de TNAP na ausência de polidocanol espalhada sobre subfases de $\mathrm{CaCl}_{2} 60$ (preto), 80 (vermelho) e 90 (verde) mmol L-1, em água pura (azul) e valores de $\mathrm{Cs}^{-1}$ em função de $\pi(\mathrm{B})$.

Com o aumento de força iônica a partir de um valor nulo (no qual não há aumento de $\pi$ em nenhum estágio de compressão) observa-se um incremento de atividade superficial e um deslocamento horizontal para a direita das isotermas, uma vez que atinge-se maiores valores de $\pi$ em todos os estágios de compressão. Este efeito também foi observado para proteínas globulares em soluções com concentrações crescentes de sais monovalentes [67]. Os valores de $\mathrm{Cs}^{-1}$ da monocamada de TNAP 
nestas condições também não excedem $50 \mathrm{mN} \mathrm{m}^{-1}$, analogamente ao que foi observado na subfase contendo $\mathrm{NaCl} 150 \mathrm{mmol} \mathrm{L}^{-1}$. É importante ressaltar que a presença de íons pode modificar a atividade enzimatica da TNAP $[39,154]$.

\subsection{Caracterização das Monocamadas Mistas de TNAP e Lipídeos}

A co-adsorção de TNAP em monocamadas de Langmuir de um determinado lipídeo pode ser realizada de diferentes maneiras, desde a injeção da enzima na presença de polidocanol sob a interface (analogamente às condições anteriores), ou ainda por meio do espalhamento dos lipídeos (seguido da compressão da interface) sobre uma subfase já contendo a enzima. Porém, independentemente da metodologia empregada, observa-se, em todas as condições, a expansão da monocamada na presença da enzima [83], caracterizando a adsorção desta na interface, aumentando os valores de áreas moleculares para cada estágio de compressão. A fim de caracterizar a interação da TNAP com as monocamadas dos lipídeos, em um primeiro momento foi averiguada a capacidade de adsorção desta na ausência e na presença do polidocanol em água pura, por meio das isotermas representadas na Figura 28.

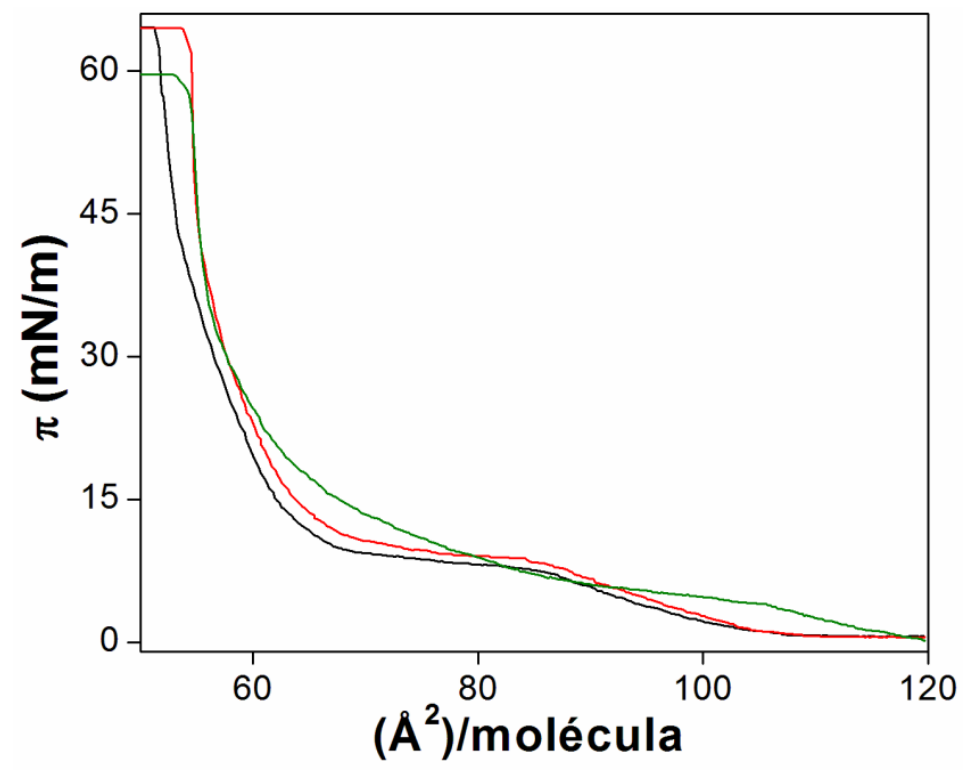

Figura 28 - Isotermas $\pi$-A de DPPC puro (preto), com TNAP na ausência (vermelho) e presença (verde) de polidocanol 1\% p/V, em subfase de água pura contendo $375 \mathrm{ng}$ da enzima. 
Enquanto há uma tênue expansão na isoterma de DPPC na subfase contendo apenas TNAP, observa-se uma expansão considerável do sistema DPPC/TNAP/polidocanol, indicando que a enzima co-adsorveu em subfase de água pura apenas na presença deste detergente. Porém, não é possível separar a adsorção da enzima da adsorção de polidocanol livre, através das isotermas. Nos trabalhos de Caseli et al., a adição de TNAP (contendo detergente a 0,01 \% p/V) ocasionou uma expansão da isoterma de um lipídeo aniônico, com extinção do platô de coexistência de fases [107]. Além disto, estes trabalhos evidenciaram uma relativa diminuição da atividade superficial (além da diminuição da concentração micelar crítica) do polidocanol na presença da enzima (frente ao polidocanol puro, em subfase aquosa) [106].

O uso de uma subfase de força iônica de $210 \mathrm{mmol} \mathrm{L}^{-1}$ induzida por $\mathrm{NaCl}$ favoreceu a adsorção da TNAP na interface líquido-ar (Figura 26), o que possivelmente favorece sua co-adsorção com uma monocamada de lipídeos. Desta forma, isotermas de lipídeo/TNAP, obtidas em uma subfase com força iônica moderada (induzidas por $\mathrm{NaCl}$ ), estão representadas na Figura 29.

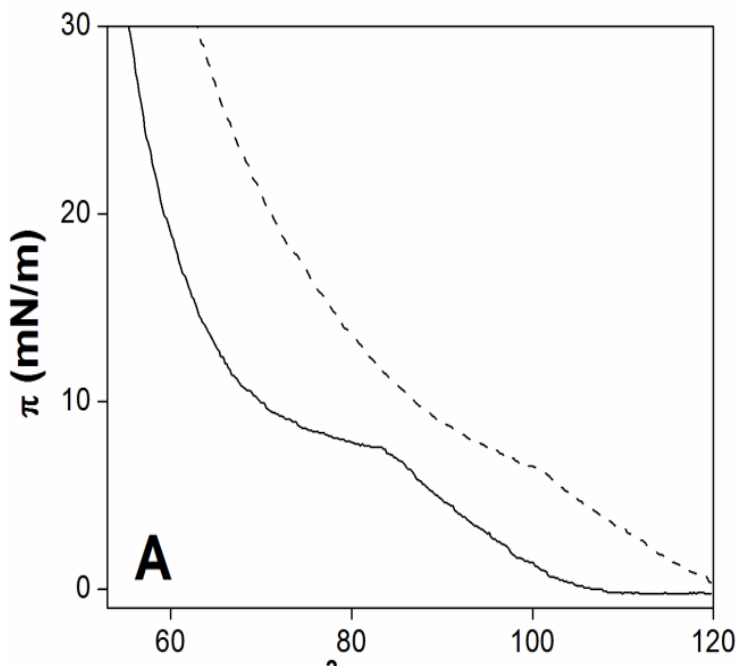

$\left(\AA^{2}\right) /$ molécula

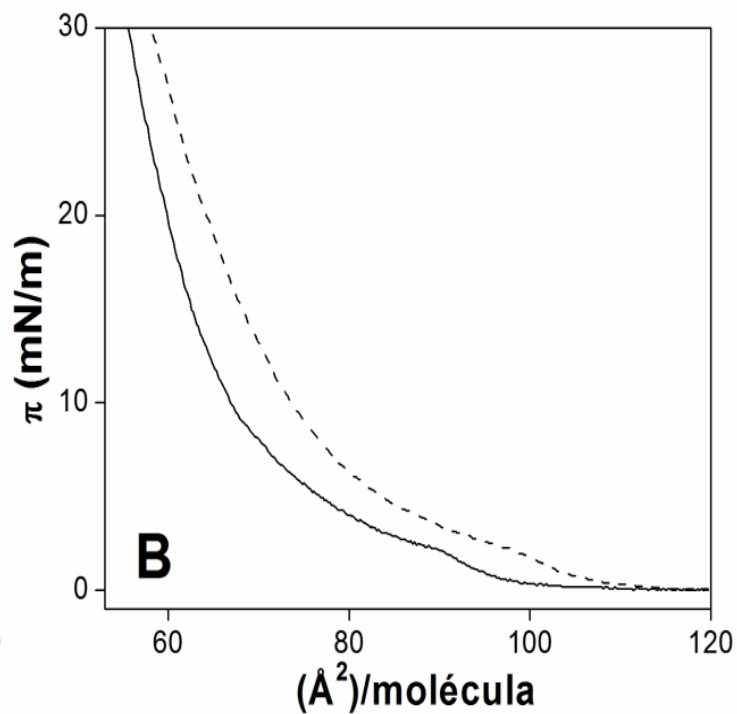

$\left(\AA^{2}\right) /$ molécula

Figura 29 - Isotermas $\pi$-A de DPPC (A) e DMPA (B) em subfases de tampão Tris-HCl $10 \mathrm{mmol} \mathrm{L}^{-1}$ contendo $\mathrm{NaCl} 150 \mathrm{mmol} \mathrm{L}^{-1}$ e $\mathrm{MgCl}_{2} 20 \mathrm{mmol} \mathrm{L}^{-1}$, na ausência (linha sólida) e presença (linha tracejada) de 12,6 $\mu \mathrm{g}$ de TNAP na ausência de polidocanol, coespalhada com os lipídeos.

Uma expansão das áreas moleculares foi observada para ambos os lipídeos na presença de TNAP, de aproximadamente $14 \%$ para o DPPC e $4,8 \%$ para o DMPA (em $\pi=30 \mathrm{mN} \mathrm{m}^{-1}$ ); indicando que é possível a co-adsorção desta nas monocamadas. A 
adsorção interfacial favorece a transferência conjunta dos lipídeos com a enzima a um suporte sólido; em contraste com a literatura, que faz uso do detergente não-iônico durante a confecção do filme LB [108].

Como pretende-se não só a transferência de TNAP para os filmes LB como também a co-adsorção de íons $\mathrm{Ca}^{2+}$, uma subfase de $\mathrm{CaCl}_{2}$ (com mesma força iônica do tampão contendo $\mathrm{NaCl}$ ) foi utilizada analogamente; condição representada nas isotermas da Figura 30. De maneira análoga aos resultados representados na Figura 19, a presença de íons $\mathrm{Ca}^{2+}$ na subfase promove compressão na monocamada de DMPA e faz com que esta apresente maior fluidez em relação à subfase de água pura. Ao ser formada na presença de TNAP, a monocamada de DMPA é expandida e torna-se ainda mais fluida.
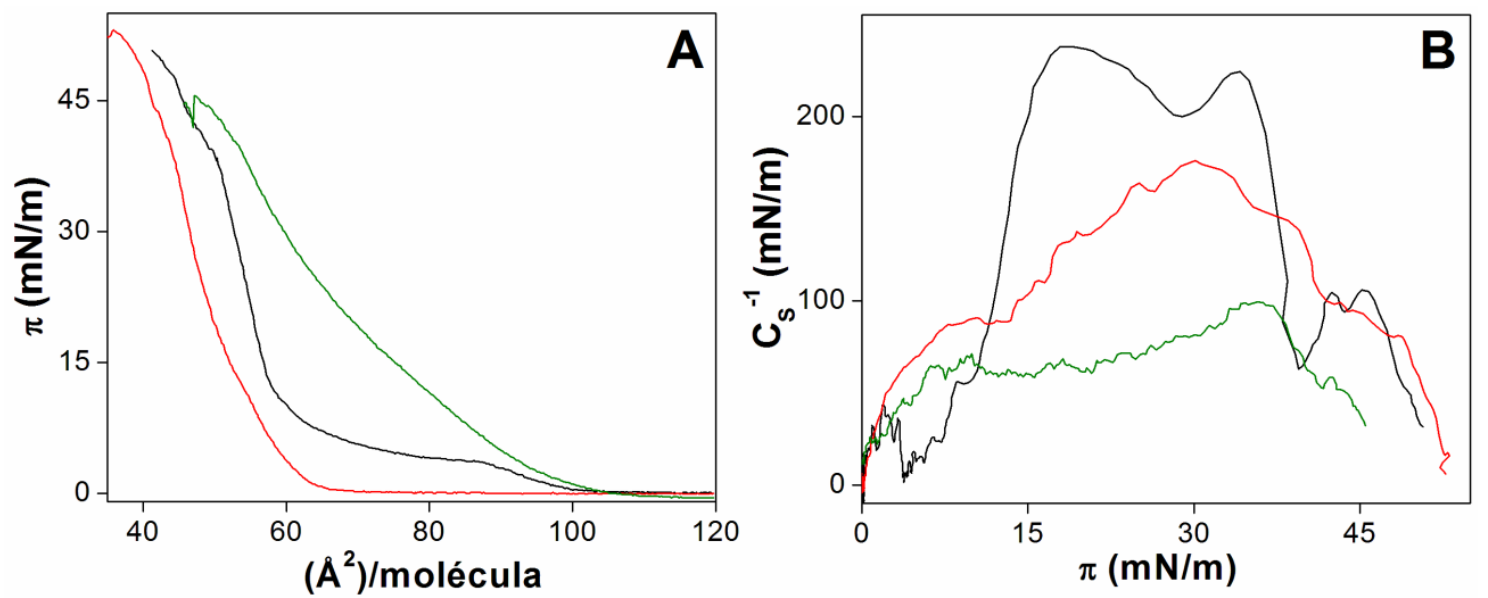

Figura 30 - Isotermas $\pi$-A (A) e valores de $\mathrm{CS}^{-1}$ em função de $\pi$ (B) de monocamadas de DMPA, em subfases de água (preta) e em $\mathrm{CaCl}_{2} 70 \mathrm{mmol} \mathrm{L}^{-1}$ na ausência (vermelha) e presença (verde) de 5,7 $\mu \mathrm{g}$ de TNAP (sem polidocanol) .

De modo a obter fases condensadas nas proximidades de $\pi=30 \mathrm{mN} \mathrm{m}^{-1}$, que foi utilizada na confecção dos filmes LB, diferentes quantidades de TNAP foram espalhadas em conjunto com a monocamada. Como o DMPA foi o melhor candidato para a construção de filmes, suas isotermas estão representadas na Figura 31, em solução de $\mathrm{CaCl}_{2}$ com força iônica de $210 \mathrm{mmol} \mathrm{L}^{-1}$ variando a quantidade de TNAP na ausência de polidocanol. A expansão e o aumento de fluidez da monocamada de DMPA são proporcionais à quantidade de enzima adicionada na interface. A partir dos gráficos da Figura 31B verifica-se que a adição de até 2,8 $\mu \mathrm{g}$ (razão molar 1:1400) de TNAP obtém-se fases condensadas para a monocamada mista. 

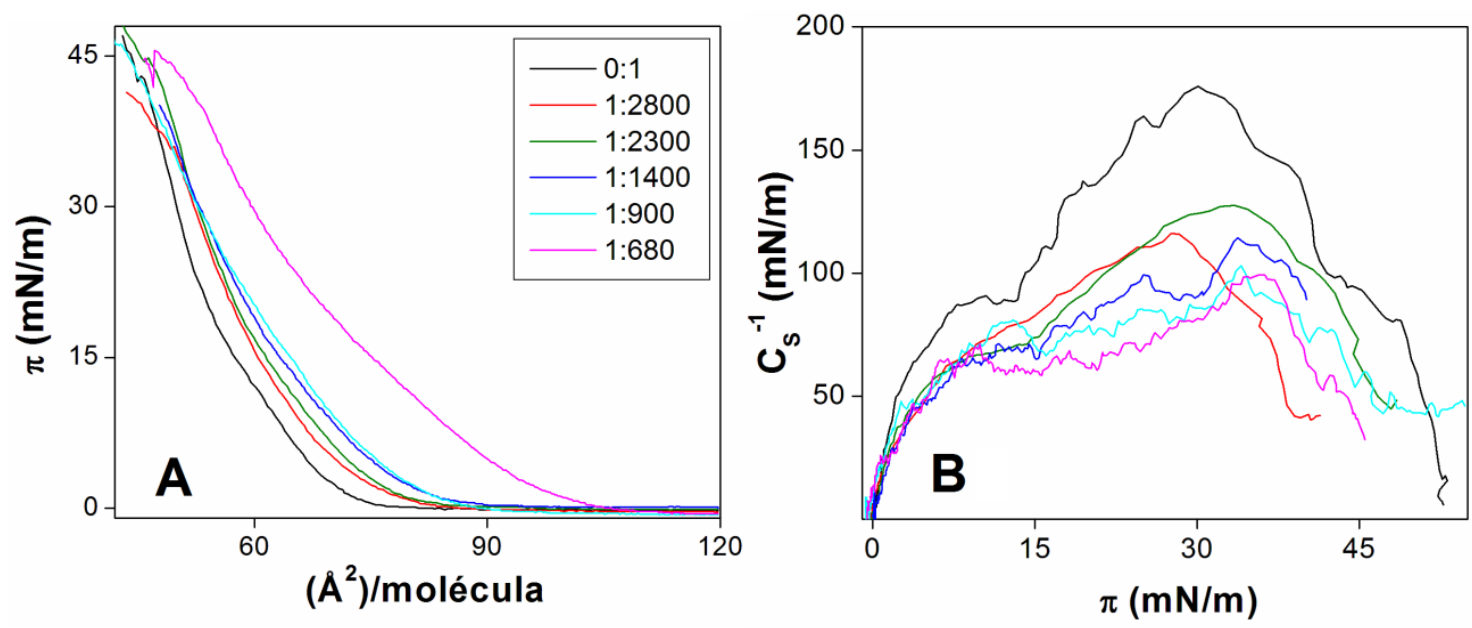

Figura 31 - Isotermas $\pi$-A (A) e valores de $\mathrm{CS}^{-1}$ em função de $\pi$ (B) de monocamadas de DMPA em subfase de $\mathrm{CaCl}_{2} 70 \mathrm{mmol} \mathrm{L}^{-1}$ na ausência e presença de diferentes razões molares de TNAP:DMPA (sem polidocanol).

A presença de TNAP nas monocamadas mistas provoca, portanto, expansão e também aumentam a fluidez das mesmas. Como serão confeccionados filmes LB mistos, é necessário averiguar o efeito que a enzima provoca na estabilidade da monocamada de DMPA a partir da $\pi$ utilizada na transferência para o suporte sólido; efeito este representado na Figura 32A.
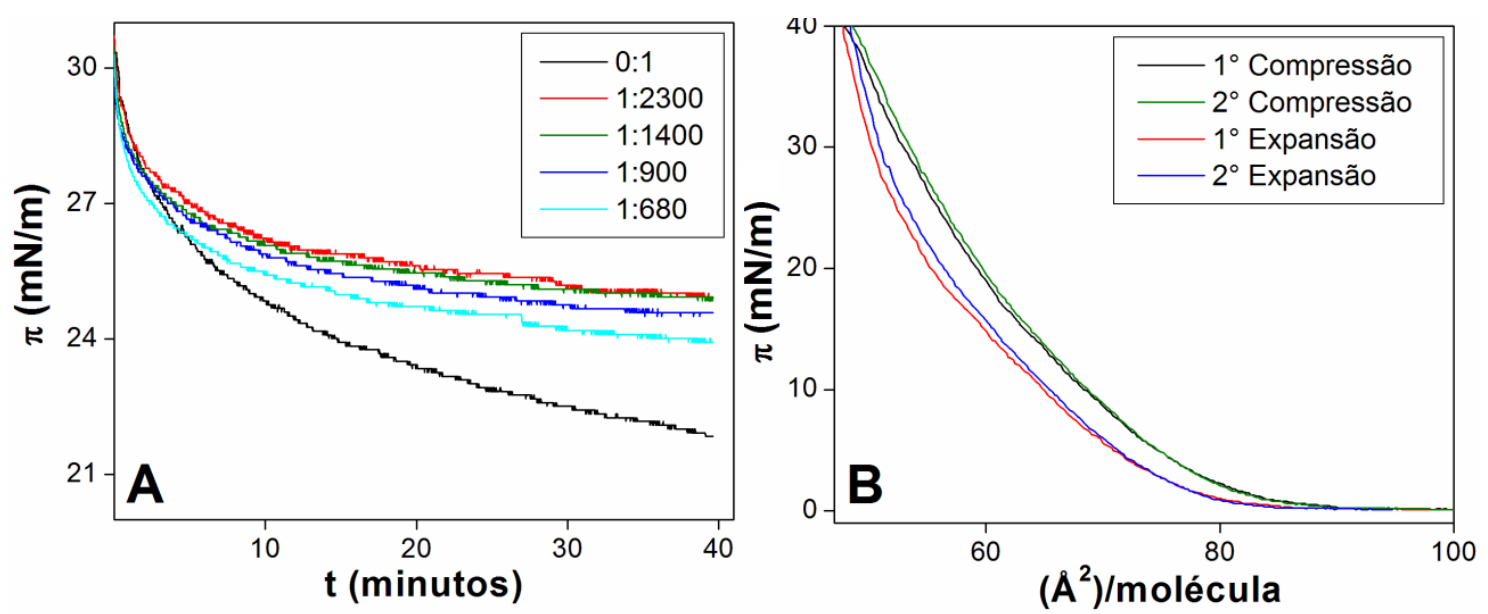

Figura 32 - Variação de $\pi$ em função do tempo para monocamadas de DMPA em subfase de $\mathrm{CaCl}_{2} 70 \mathrm{mmol} \mathrm{L}{ }^{-1}$ na ausência e presença de diferentes razões molares de TNAP:DMPA (sem polidocanol) (A) e ciclos de compressão e expansão de isoterma $\pi$ A de monocamada mista de TNAP:DMPA 1:1400 em subfase de $\mathrm{CaCl}_{2} 70 \mathrm{mmol} \mathrm{L}^{-1}$ (B).

Na presença de TNAP observa-se menor decaimento de $\pi$ em função do tempo das monocamadas mistas em relação ao DMPA puro, enquanto o aumento da 
quantidade de enzima (caracterizado pelo aumento da razão molar TNAP:DMPA) provoca não somente aumento da fluidez (Figura 31B) como também desestabiliza a monocamada, aumentando a taxa de decréscimo de $\pi$ proporcionalmente à quantidade de TNAP. Um efeito similar foi observado para uma monocamada mista de lipídeo/metaloproteína [113], cuja estabilidade fora diminuída nas condições de maior fluidez.

A estabilização de monocamadas lipídicas pela presença de proteínas na interface líquido-ar tem sido descrita na literatura [155]. Estes trabalhos demonstram que não só enzimas contendo grupos hidrofóbicos (como a âncora GPI da TNAP que interage favoravelmente com a monocamada lipídica estabilizando-a) como também proteínas globulares promovem estabilização da monocamada mista, por meio de interações hidrofóbicas e eletrostáticas. $\mathrm{Na}$ monocamada mista, não ocorre o fenômeno de agregação irreversível entre o DMPA e a TNAP, uma vez que não se observa histerese nos primeiros ciclos de compressão/expansão deste sistema misto (Figura 32B).

As imagens de micrografias de BAM das monocamadas de DMPA na ausência e presença de TNAP (na razão molar de TNAP:DMPA 1:1400) estão representadas na Figura 33. Verifica-se que as monocamadas de DMPA (em subfase de $\mathrm{CaCl}_{2} 70 \mathrm{mmol}$ $\mathrm{L}^{-1}$ ) estruturam-se em agregados circulares de dimensões micrométricas, em baixos valores de $\pi$, Estes condensados de DMPA aproximam-se com o aumento de $\pi$, formando agregados maiores até a obtenção de uma monocamada homogeneamente distribuída a partir de $30 \mathrm{mN} \mathrm{m}^{-1}$; tal comportamento já fora relatado na literatura para monocamadas de lipídeos insolúveis anfifílicos em subfases de alta força iônica [156].

A transição de uma fase expandida para mais condensada ocorre após $\pi=15 \mathrm{mN}$ $\mathrm{m}^{-1}$ para a monocamada de DMPA nesta subfase (com Cs ${ }^{-1}$ acima de $100 \mathrm{mN} \mathrm{m}^{-1}$, como observado na Figura 19). Na Figura 33, observa-se acima desta $\pi$ um aumento da ocorrência de agregados e de pontos de maior reflexividade, possivelmente relacionado com a formação de domínios condensados (de acordo com o que fora observado nas isotermas). 

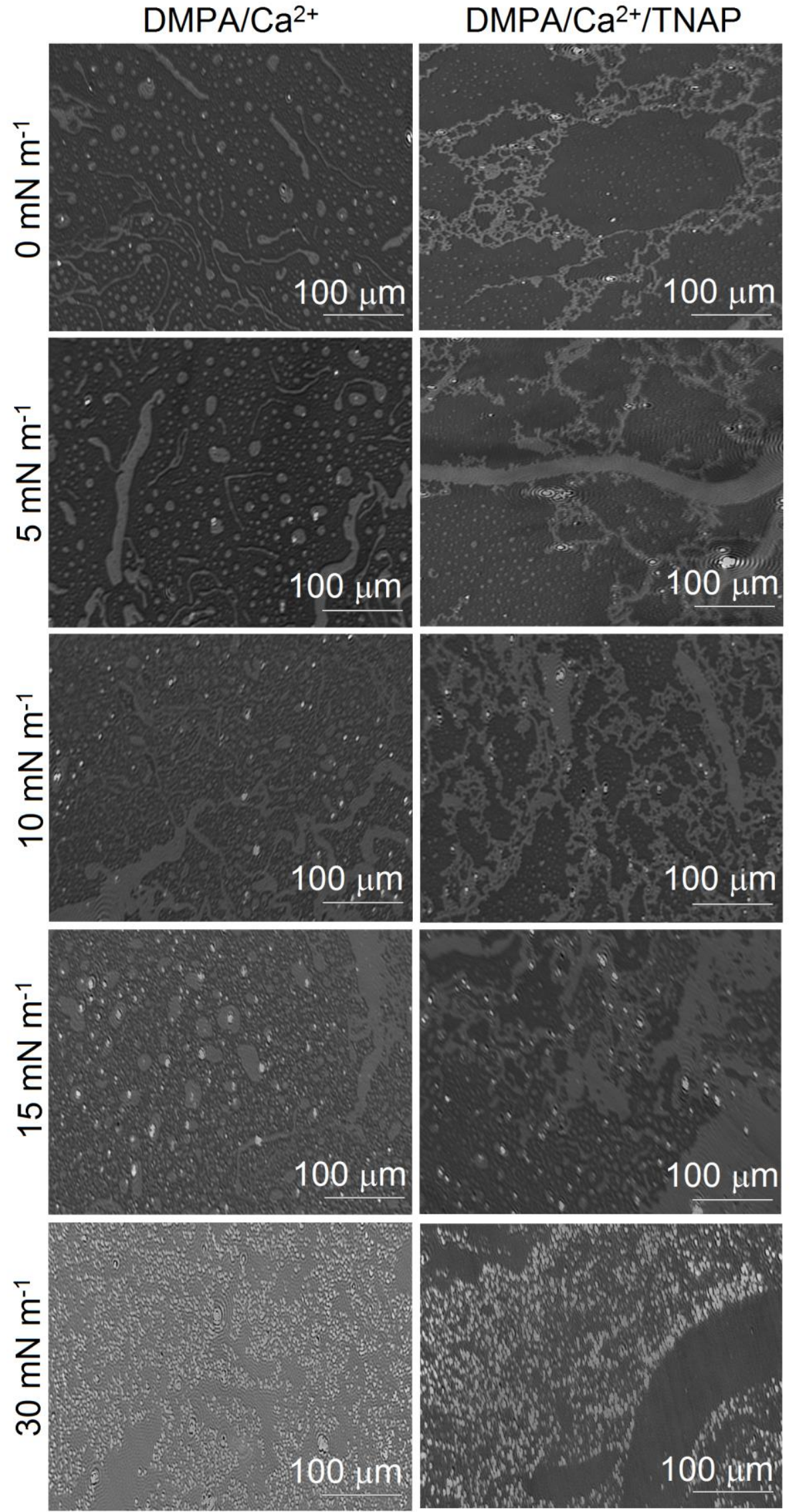

Figura 33 - Imagens de microscopia BAM de monocamadas de DMPA em $\mathrm{CaCl}_{2} 70$ mmol L $\mathrm{L}^{-1}$, na ausência e presença de TNAP (razão molar TNAP:DMPA 1:1400), em diferentes estágios de compressão. 
A adição de TNAP à monocamada de DMPA intensifica o fenômeno de agregação até mesmo em $\pi$ nula. Observa-se um favorecimento na formação de domínios alongados, de maiores dimensões em detrimento daqueles redondos observados na monocamada de DMPA pura. A expansão da isoterma $\pi$-A da monocamada na presença da enzima (Figura 30) mesmo em estados expandidos é justificada pela introdução de grupos lipídeos na interface.

No caso da TNAP, a formação de agregados em estados expandidos está relacionada à adsorção de um grupo hidrofóbico na interface ar-líquido (âncora GPI, representada na Figura 6), intensificando as interações hidrofóbicas das cadeias laterais dos lipídeos. A intensificação destas interações possivelmente é acompanhada de um aumento na repulsão eletrostática entre os dipolos formados pelas moléculas de DMPA orientadas na interface, desestabilizando os domínios circulares; provocando a formação dos domínios alongados observados [85].

Diferentes trabalhos demonstram que enzimas ligadas a um grupo GPI orientamse com tal âncora para o exterior da interface ar-líquido (perpendicular ao plano da interface), enquanto a cadeia aminoacídica da enzima permanece paralela à interface [68,157]. Há também uma aproximação destes agregados alongados com o aumento de $\pi$, de maneira análoga ao que fora observado para uma monocamada mista de lipídeo/TNAP em subfase de alta força iônica [90]. O aumento na reflexividade a altas $\pi$, aliado a uma indução na agregação de DMPA na presença de TNAP, já foram relatados na literatura [158].

Para a razão molar de TNAP:DMPA 1:1400, observa-se que a partir de $\pi=15$ $\mathrm{mN} \mathrm{m} \mathrm{m}^{-1}$ (até uma pressão de $30 \mathrm{mN} \mathrm{m}^{-1}$ ) a monocamada mista atinge uma fase condensada sem mudanças significativas nos valores de $\mathrm{CS}_{\mathrm{S}}^{-1} \mathrm{em}$ função da compactação da interface (Figura 31); entretanto, apesar da ausência de variação deste parâmetro indicar que não há transições de fase, observa-se que a monocamada organiza-se cada vez mais com a diminuição da área interfacial, até a obtenção de uma monocamada uniforme.

A caracterização da interação da TNAP com as monocamadas não se restringe à análise dos efeitos sobre a rigidez e expansão destas, mas também à avaliação do aumento da $\pi$ após a penetração da enzima na monocamada a partir de diferentes $\pi$; obtendo o valor de $\pi_{\mathrm{exc}}$, por meio dos resultados representados na Figura 34 .

Para a monocamada de DMPA, observa-se um aumento dos valores de $\Delta \pi$ para menores $\pi$ (Figura 34A); obtendo uma extrapolação para o valor de $\pi_{\text {inicial }}$ a partir do 
qual $\Delta \pi$ será nulo correspondente a $18,7 \pm 1,4 \mathrm{mN} \mathrm{m}^{-1}$, que é o valor de $\pi_{\text {exc. }}$ A obtenção de valores de $\Delta \pi$ indica que, para $\pi_{\mathrm{i}}$ abaixo da $\pi_{\mathrm{exc}}$, há uma efetiva penetração da TNAP nas monocamadas, uma vez que interações eletrostáticas da proteína com os grupos polares dos lipídeos da monocamada sem devida penetração não provocam variações nos valores de $\pi$ do sistema [91].
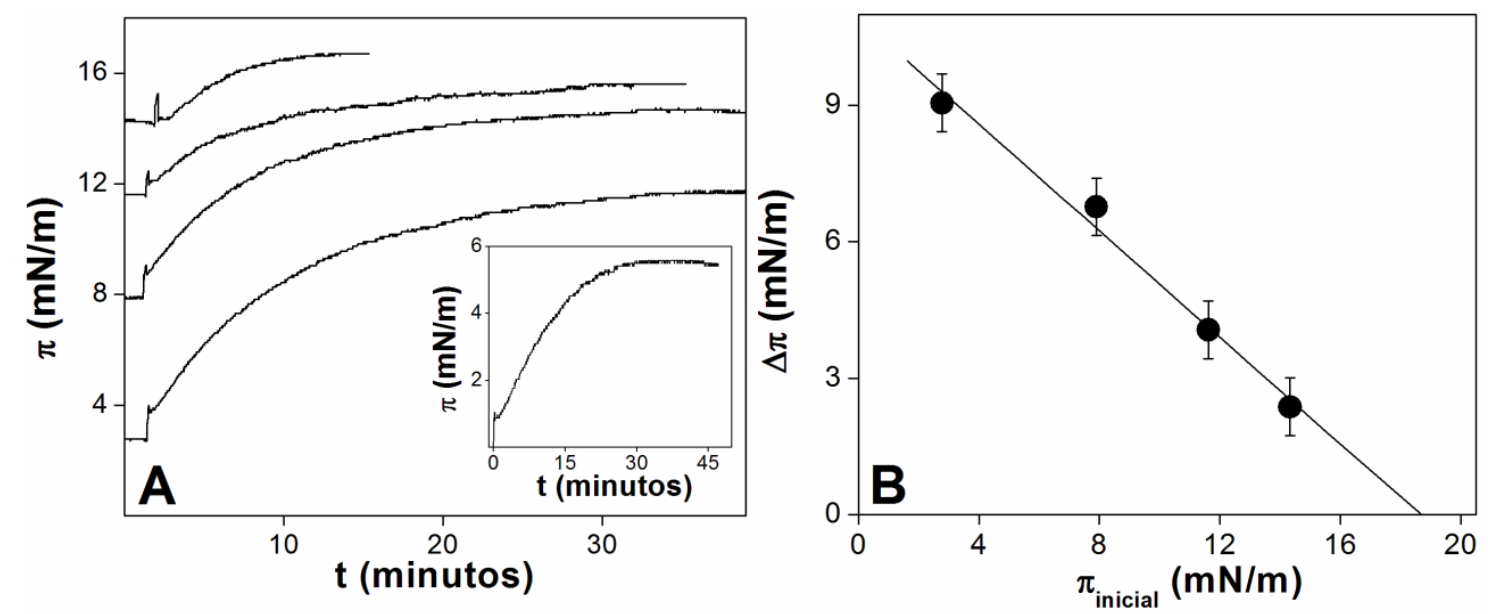

Figura $34-\Delta \pi$ da monocamada de DMPA, a partir de diferentes valores de $\pi_{\text {inicial }}$ com a injeção de TNAP (sem polidocanol, até obter razão molar TNAP:DMPA 1:1400) em subfase de $\mathrm{CaCl}_{2} 70 \mathrm{mmol} \mathrm{L}^{-1}$ (A) e representação gráfica dos valores de $\Delta \pi$ em função de $\pi_{\text {inicial }}(\mathrm{B})$. Inserção: Variação de $\pi$ em função do tempo ao injetar $2,8 \mu \mathrm{g}$ de TNAP (sem polidocanol) em $\mathrm{CaCl}_{2} 70 \mathrm{mmol} \mathrm{L}{ }^{-1}$.

Tal valor de $\pi_{\text {exc }}$ é consideravelmente próximo daquele relatado na literatura para a penetração de TNAP solubilizada com polidocanol $0,01 \%$ em uma monocamada de DMPA, correspondente a $20 \mathrm{mN} \mathrm{m}^{-1}$ [158]. Isto indica que a presença do detergente em baixa concentração não provoca diferenças significativas na penetração ou na miscibilidade da enzima na monocamada. A presença da monocamada afeta também a migração da enzima em relação à interface nua, uma vez que com a injeção da mesma quantidade de TNAP em solução de $\mathrm{CaCl}_{2} 70 \mathrm{mmol} \mathrm{L}^{-1}$, foi observado um menor valor de $\Delta \pi$ (inserção da Figura 34A) que aquele esperado para um valor de $\pi$ inicial nulo.

O efeito do colesterol na penetração da TNAP nas monocamadas de DMPA foi averiguado por meio dos valores de $\pi_{\mathrm{exc}}$, representados na Figura 35. Verifica-se que um aumento na proporção de colesterol favorece a incorporação da TNAP nas monocamadas mistas. Este efeito pode estar relacionado ao aumento da fluidez da monocamada na presença de colesterol; como demonstrado pelos menores valores de 
$\mathrm{CS}^{-1}$ para monocamadas contendo colesterol 4:1 e 1:1 em relação ao DMPA puro para todo o intervalo de $\pi$ (Figura 20).

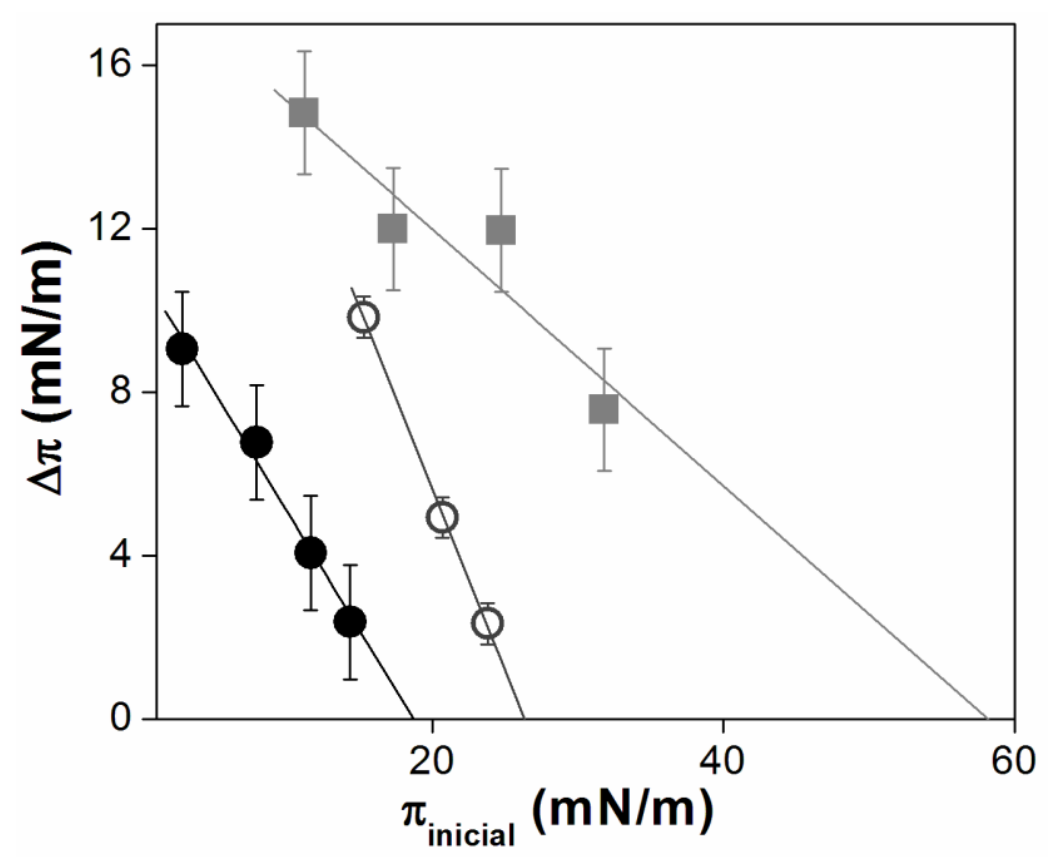

Figura $35-\Delta \pi$ das monocamadas mistas de DMPA:Chol, nas proporções de 1:0 (•), 4:1 (○) e 1:1 (ロ), a partir de diferentes valores de $\pi_{\text {inicial }}$ com a injeção de TNAP (sem polidocanol, razão molar TNAP:lipídeos 1:1400) em subfase de $\mathrm{CaCl}_{2} 70 \mathrm{mmol} \mathrm{L}{ }^{-1}$.

Em contraste a este resultado, a incorporação da TNAP em lipossomos é desfavorecida com o aumento da quantidade de colesterol na constituição da membrana mimética [159] (apesar deste também aumentar a fluidez do sistema, como observado na Figura 20). A observação do efeito oposto em proteolipossomos pode ser decorrente das diferenças na organização molecular dos lipídeos, principalmente em relação ao parâmetro crítico de empacotamento de cada um destes sistemas modelo de membrana. Tais características estruturais irão favorecer ou desfavorecer a inserção da âncora hidrofóbica da TNAP.

Observa-se mais claramente esta tendência (aumento da fluidez da monocamada pela presença do colesterol, provocando um aumento na $\pi_{\text {exc }}$ ) utilizando-se os valores de $\mathrm{CS}_{\mathrm{S}}^{-1}$. Para tal, deve-se analisar os valores de $\mathrm{CS}_{\mathrm{S}}^{-1}$ obtidos para $\pi=\pi_{\text {exc }}$; ou seja, os valores de $\mathrm{C}_{\mathrm{S}}{ }^{-1}$ representados na Figura 20B para $\pi$ correspondente ao valor de $\pi_{\mathrm{exc}}$ obtido na Figura 35 (valores representados na Tabela 4). Desta forma, observa-se que o aumento na fluidez da monocamada (diminuição de $\mathrm{CS}^{-1}$ ) provoca um aumento na $\pi_{\text {exc }}$ (facilitando a penetração da TNAP na monocamada). $\mathrm{O}$ valor de $\mathrm{C}_{S^{-1}}$ para a 
monocamada de DMPA/Chol 1:1 não fora representado, pois tal $\pi_{\text {exc }}$ excede o $\pi$ de colapso da monocamada. Valores de $\pi_{\text {exc }}$ que excedem os valores máximos de $\pi$ a serem atingidos para uma monocamada já foram relatados na literatura [72].

Tabela 4 - Valores de pressões de exclusão para monocamadas mistas de DMPA/Chol em diferentes proporções e valores de $\mathrm{C}_{\mathrm{S}}{ }^{-1}$ nas pressões de exclusão

\begin{tabular}{ccc}
\hline $\begin{array}{c}\text { DMPA:Chol } \\
(\mathrm{mol}: \mathrm{mol})\end{array}$ & $\begin{array}{c}\pi_{\mathrm{exc}} \\
\left(\mathrm{mN} \mathrm{m}^{-1}\right)\end{array}$ & $\begin{array}{c}\mathrm{Cs}^{-1} \\
\left(\mathrm{mN} \mathrm{m}^{-1}\right)\end{array}$ \\
\hline $1: 0$ & $18,7 \pm 1,4$ & $294 \pm 12$ \\
$4: 1$ & $26,3 \pm 0,5$ & $190 \pm 15$ \\
$1: 1$ & $58,2 \pm 15,5$ & - \\
\hline
\end{tabular}

\subsection{Caracterização dos Filmes Mistos de TNAP e DMPA}

Os filmes LB mistos de DMPA (melhor candidato com condições ótimas de deposição) com TNAP foram confeccionados sob diferentes condições; em um primeiro momento por meio da simples adsorção física da enzima sobre a superfície já modificada com o filme, ou ainda por meio da transferência simultânea de lipídeo e enzima. Um fator em comum entre as diferentes metodologias (também adotado nos ensaios de atividade fosfohidrolítica e de mineralização) foi a ausência de polidocanol na solução de TNAP.

\subsubsection{Imobilização de TNAP por meio de Adsorção Física}

A imobilização da TNAP em um filme LB pode ser realizada por meio da adsorção física, na qual expõe-se o suporte sólido com o filme pré-formado a uma solução da enzima [106]. Utiliza-se um número ímpar de camadas, a fim de possibilitar a adsorção da enzima através de sua âncora GPI em uma face hidrofóbica do filme. Tendo em vista que o DMPA foi o melhor candidato dentre os lipídeos caracterizados anteriormente, todos os filmes mistos com a enzima foram confeccionados utilizando este lipídeo negativamente carregado.

A subfase utilizada na confecção do filme de DMPA foi de $\mathrm{CaCl}_{2} 0,1 \mathrm{mmol} \mathrm{L}{ }^{-1}$ (tendo em vista a maior rigidez das monocamadas nesta solução), constituindo um filme de DMPA/Ca ${ }^{2+}$; construído a partir da transferência homogênea (com um $\mathrm{R}_{\text {trans }}$ de 1,10 ) 
de 3 monocamadas ao suporte sólido. A quantificação da massa de TNAP adsorvida neste filme de DMPA/Ca ${ }^{2+}$ está representada na Figura 36. A quantidade de enzima adsorvida após a exposição do filme LB atinge saturação após um intervalo de tempo de 15 minutos. Em um estudo prévio [106], a transferência de TNAP (contendo polidocanol 0,01\%) não foi tempo-dependente ao expor um filme de DMPA/ $\mathrm{Zn}^{2+}$ a uma solução da enzima, devido à adsorção da enzima na interface líquido-ar. Por outro lado, observa-se que a adsorção física da TNAP na ausência do detergente é tempo dependente (Figura 36), indicando que é um processo governado por difusão, possivelmente devido à distribuição homogênea da enzima em sua solução na ausência de polidocanol.

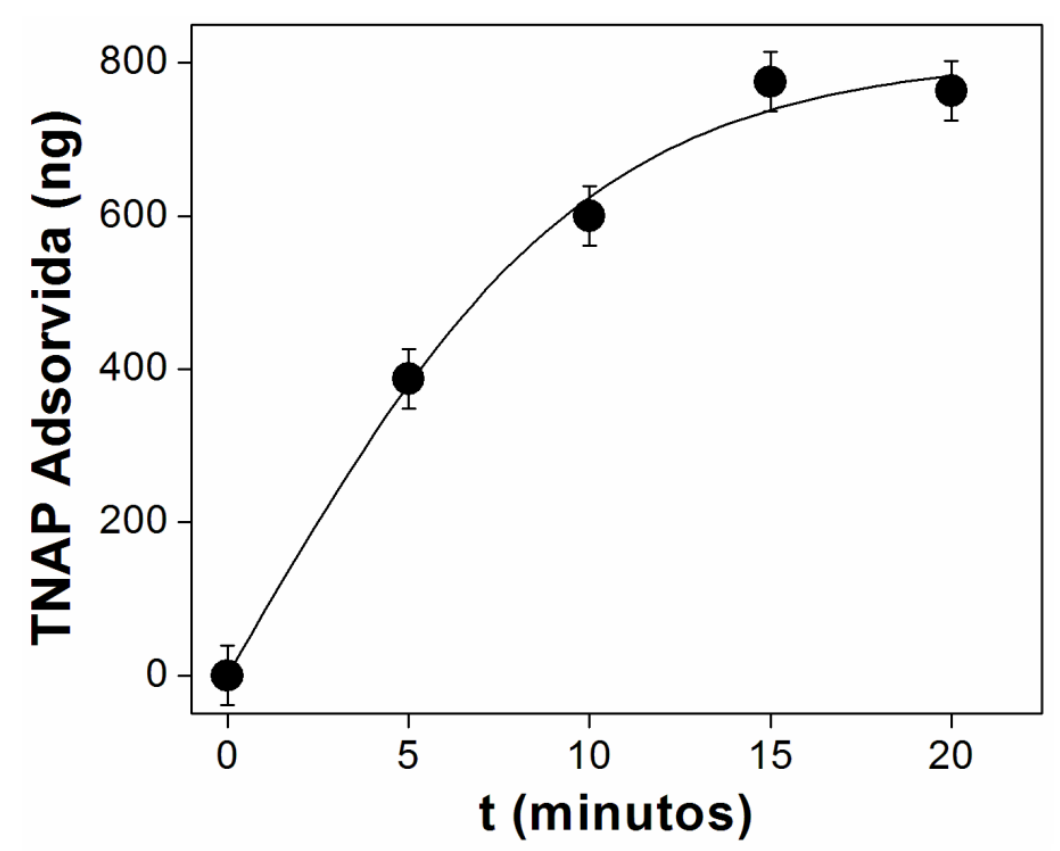

Figura 36 - Quantificação da massa de DMPA/Ca ${ }^{2+}(\mathrm{n}=3)$ imobilizado sobre um cristal de quartzo recoberto com ouro, ao ser exposto a uma solução de TNAP 2,64 $\mu \mathrm{g}$ $\mathrm{mL}^{-1}$ por diferentes intervalos de tempo.

A densidade superficial de enzima fisicamente adsorvida no filme foi de $342,8 \mathrm{ng}$ $\mathrm{cm}^{-1}$. Considerando a área total do cristal de quartzo sobre a qual deposita-se o filme $\left(2,97 \mathrm{~cm}^{2}\right)$ e um peso molecular de $130 \mathrm{kDa}$ para a TNAP, obtém-se um valor de área molecular para a enzima próximo a $6300 \AA^{2}$ molécula $^{-1}$. Considerando de maneira aproximada a área da TNAP de $5000 \AA^{2}$ molécula $^{-1}$ a deposição da enzima sobre o filme LB aparentemente ocorre em um regime de uma monocamada de enzima; bem como observado em estudos anteriores [108,160]. 


\subsubsection{Imobilização de TNAP a Partir das Monocamadas Mistas}

A confecção de filmes LB a partir das monocamadas mistas foi realizada utilizando uma subfase contendo $\mathrm{CaCl}_{2} 70 \mathrm{mmol} \mathrm{L}^{-1}$, caracterizada anteriormente como uma condição que aumenta a atividade superficial de TNAP. A quantificação da massa dos filmes mistos de DMPA/ $\mathrm{Ca}^{2+}$, obtidos a partir de diferentes quantidades de TNAP, foi realizada através da transferência de monocamadas a partir da emersão sobre um cristal de quartzo recoberto com ouro. Os valores de massa e parâmetros de deposição dos filmes mistos estão representados na Figura 37 e na Tabela 5.
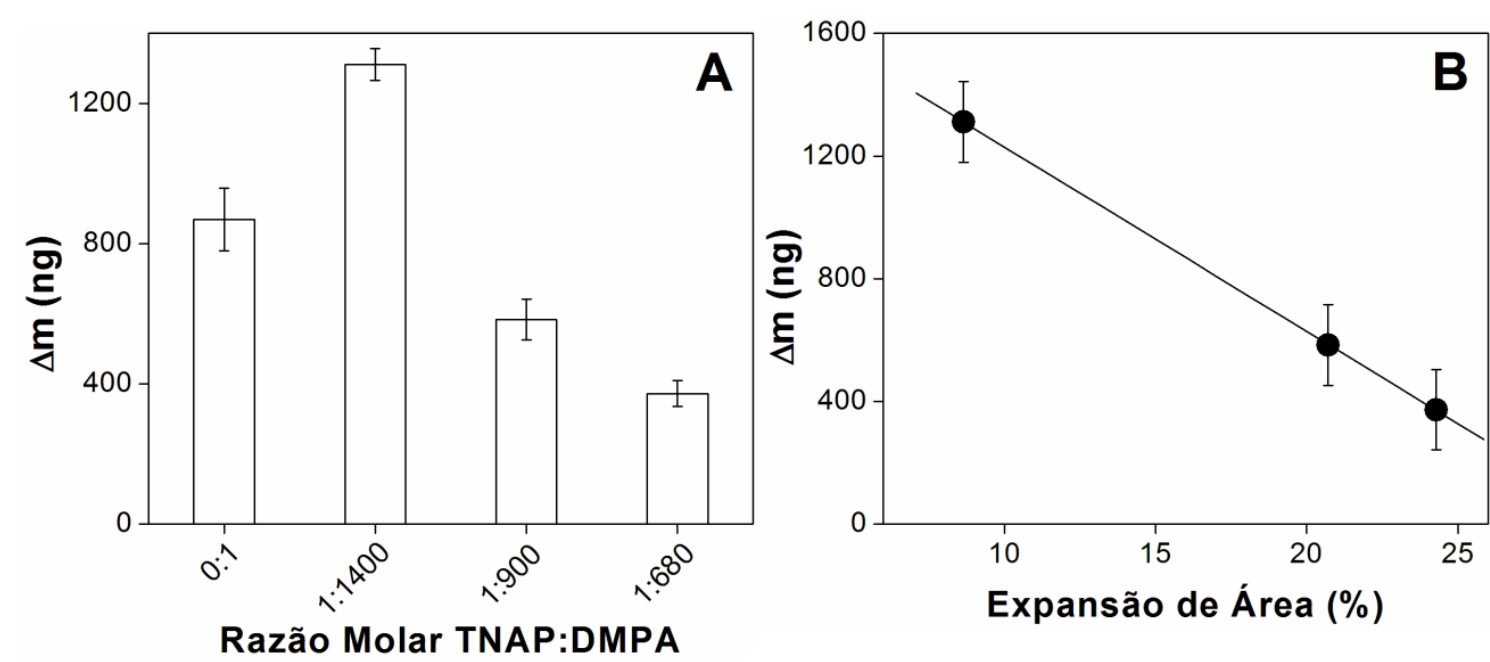

Figura 37 - Massa dos filmes mistos $(\Delta \mathrm{m})$ em função da razão molar de TNAP:DMPA nas monocamadas mistas (A) e da expansão de área provocada pela enzima na monocamada de DMPA (B).

Observa-se que a massa dos filmes LB mistos de TNAP/DMPA é inversamente proporcional à quantidade de enzima espalhada com o lipídeo (Figura 37A). Somado a isto, a massa dos filmes mistos é inversamente proporcional à expansão da isoterma de DMPA causada pela presença da enzima (Figura 37B, sendo a expansão da isoterma proporcional à quantidade de TNAP espalhada na interface ar-líquido). Estes valores podem ser menores que os obtidos para um filme de DMPA puro formado a partir de $\mathrm{CaCl}_{2}$ (Tabela 5); possivelmente devido a um aumento na fluidez da monocamada proporcional à quantidade de TNAP co-espalhada na interface (Figura 31B), uma vez as condições de deposição (valor de $\pi=30 \mathrm{mN} \mathrm{m}^{-1}$ ) foram as mesmas. As transferências de uma monocamada mista ao suporte da QCM apresentaram valores de $\mathrm{R}_{\text {trans }}$ menores que a unidade (Tabela 5), indicando transferências não-uniformes 
(devido efeito de rugosidade superficial do suporte sólido sobre a $1^{\circ}$ camada depositada de um filme LB).

Tabela 5 - Quantificação de massa de DMPA/Ca ${ }^{2+}$ em filmes mistos com diferentes razões de TNAP:DMPA co-espalhadas na interface

\begin{tabular}{cccc}
\hline $\begin{array}{c}\text { TNAP:DMPA } \\
(\text { mol:mol })\end{array}$ & $\begin{array}{c}\text { Filme Misto } \\
(\mathrm{ng})\end{array}$ & $\begin{array}{c}\text { Expansão }{ }^{*} \text { de Área } \\
(\%)\end{array}$ & $\mathrm{R}_{\text {trans. }}$ \\
\hline $0: 1$ & $1737 \pm 89$ & - & 0,59 \\
$1: 1400$ & $2622 \pm 46$ & 8,6 & 0,61 \\
$1: 900$ & $1166 \pm 58$ & 20,7 & 0,50 \\
$1: 680$ & $744 \pm 37$ & 24,9 & 0,55 \\
\hline
\end{tabular}

\subsection{Atividade Fosfohidrolítica da TNAP}

\subsubsection{Em Meio Homogêneo}

A dosagem proteica é necessária na estimativa da atividade específica em meio homogêneo, uma vez que permite determinar a quantidade de enzima que estará presente no meio reacional. A Figura 38 traz os valores de concentração para diferentes ensaios de dosagem da TNAP, após tratamento em resina hidrofóbica para remoção do polidocanol, apresentando valores próximos e reprodutíveis em torno de $27,1 \pm 0,5 \mu \mathrm{g}$ $\mathrm{mL}^{-1}$. A concentração de enzima antes da retirada do polidocanol era de $54 \mu \mathrm{g} \mathrm{mL}^{-1}$, indicando que durante a remoção do detergente há uma diminuição de cerca de $50 \%$ da quantidade de TNAP.

A atividade fosfohidrolítica da TNAP na ausência de polidocanol foi estimada por meio de análise cinética contínua por espectrofotometria, utilizando pNFF em condições ótimas de reação. Os espectros da formação de $\mathrm{pNF}^{-}$estão representados na Figura 39A e as atividades específicas obtidas em diferentes dias na Figura 39B. A Tabela 6 traz as atividades específicas da TNAP em meio homogêneo, sob diferentes condições. 


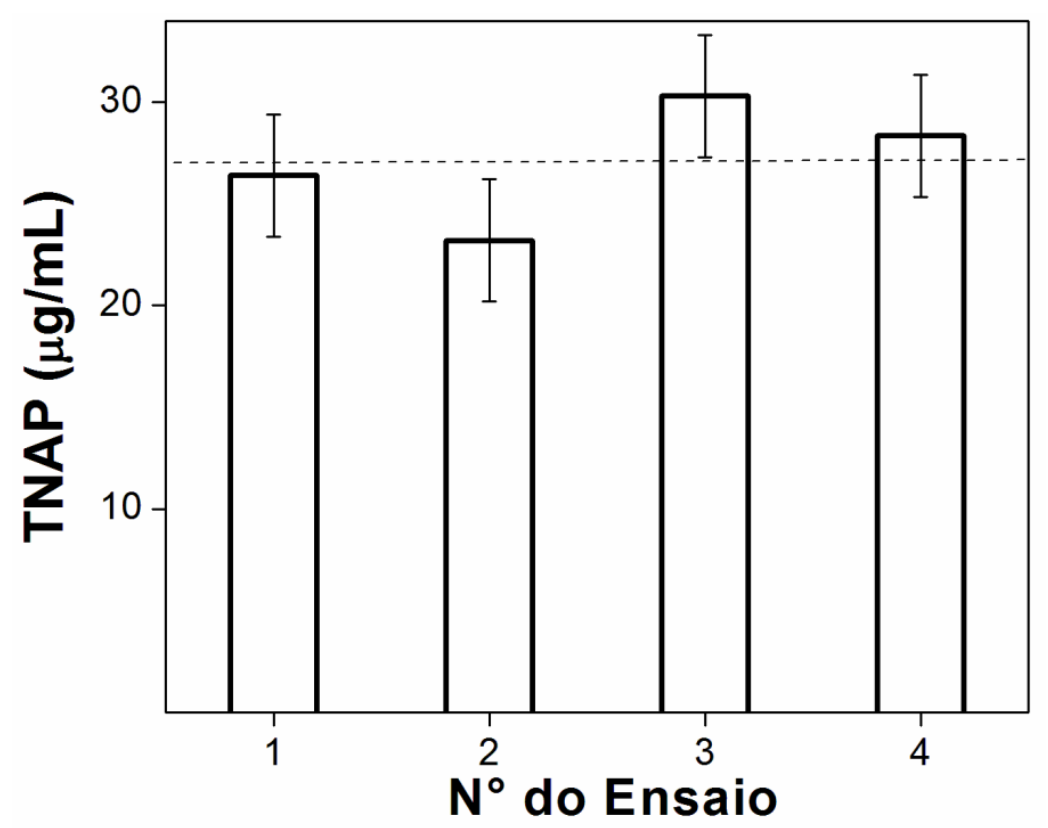

Figura 38 - Concentrações de TNAP em diferentes ensaios pós-remoção do polidocanol, com valor médio de concentração proteica (linha tracejada).
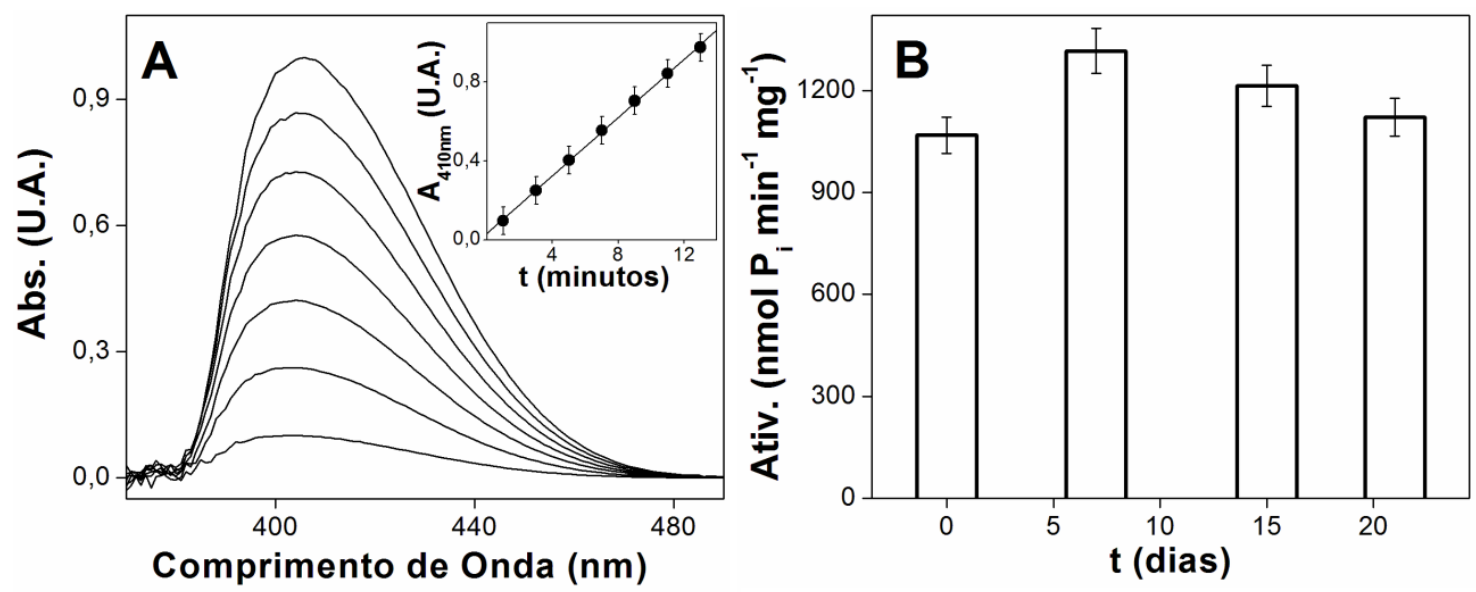

Figura 39 - Análise cinética contínua em meio homogêneo: Espectros UV-Vis da formação de $\mathrm{pNF}^{-}$obtidos em intervalos de tempo de 2 minutos (A) e valores de atividades específica da TNAP (sem polidocanol) em função do tempo de estocagem (B). Inserção: valores de absorção em $410 \mathrm{~nm}$ em função do tempo de reação.

A remoção de polidocanol promove não só diminuição na concentração enzimática como também queda de aproximadamente $50 \%$ da atividade específica da enzima. A fim de avaliar se tal atividade permanece constante durante o tempo de estocagem da enzima foram realizados ensaios cinéticos em intervalos de tempo de dias, nos quais não ocorreu nenhuma perda significativa de atividade fosfohidrolítica da TNAP. A ocorrência de agregação que ocasiona diminuição na atividade enzimática é mencionada na literatura e prevenida com a adição de detergentes [44]. A atividade 
pNFFase da TNAP em meio homogêneo foi estimada na ausência e presença dos antibióticos gentamicina e fungizona. Os valores obtidos estão representados na Figura 40.

Tabela 6 - Atividades específicas de TNAP em meio homogêneo para diferentes condições experimentais

\begin{tabular}{ccc}
\hline Condição & $\begin{array}{c}\text { Metodologia } \\
\text { Empregada }\end{array}$ & $\begin{array}{c}\text { Atividade Específica } \\
\left(\mathrm{nmol} \mathrm{P}_{\mathrm{i}} \mathrm{min}^{-1} \mathrm{mg}^{-1}\right)\end{array}$ \\
\hline Com Polidocanol 1\% $(\mathrm{p} / \mathrm{V})$ & Espectrofotometria Tradicional & $(2671 \pm 15)$ \\
Sem Polidocanol & Espectrofotometria Tradicional & $(1474 \pm 15)$ \\
& ADSA/DRUV & $(1624 \pm 129)$ \\
\hline
\end{tabular}

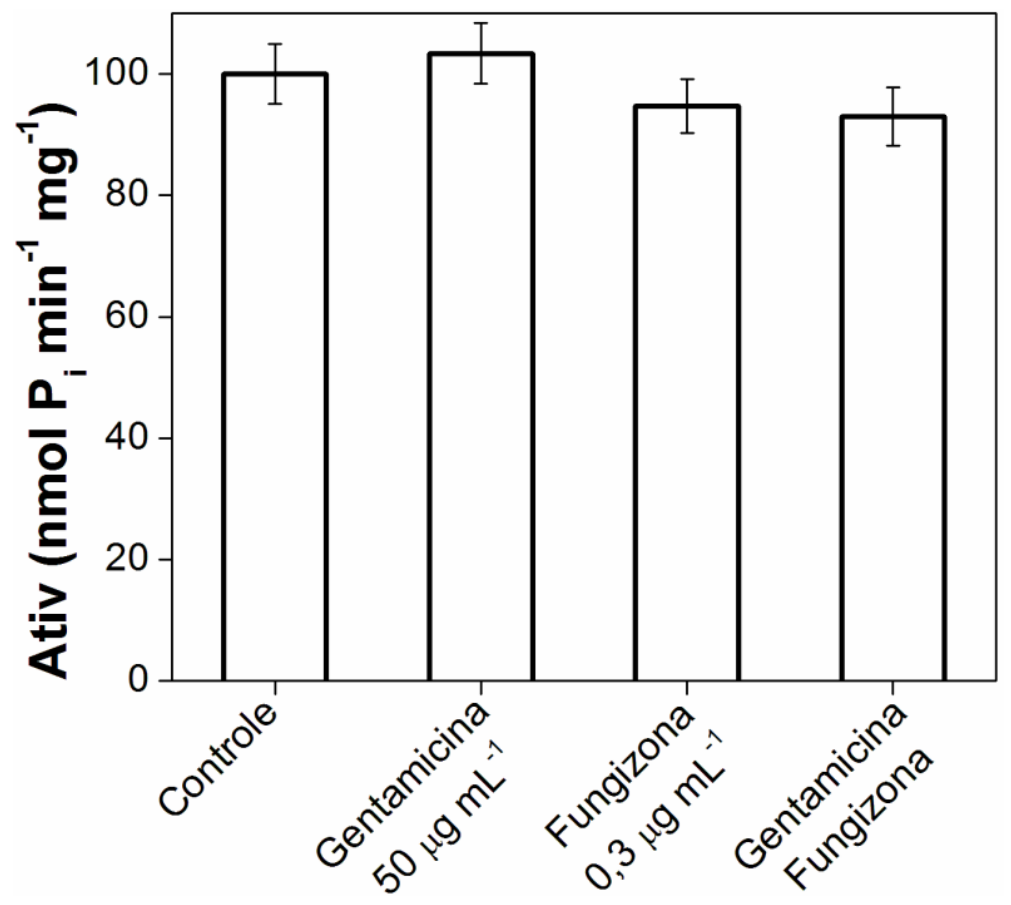

Figura 40 - Valores normalizados de atividade específica pNFFase da TNAP em meio homogêneo, na ausência e presença de gentamicina e fungizona.

Observa-se que a presença destes antibióticos, nas concentrações indicadas, no meio reacional não provoca alterações significativas na atividade enzimática, dentro do erro experimental indicado. Isto possibilita o uso dos mesmos em ensaios de mineralização, a fim de suprimir a proliferação de microrganismos (bactérias e fungos) indesejáveis. 


\subsubsection{Em Uma Gota Pendente}

A atividade fosfohidrolítica da TNAP em um microambiente de uma gota pendente de meio reacional foi estimada, através da espectrofotometria DRUV (obtenção dos espectros UV-Vis) acoplada à técnica ADSA (obtenção dos volumes da gota e valores de $\gamma$ representados na Figura 15). Para tal, faz-se necessária uma relação entre os valores de absorbância obtidos através da técnica DRUV com as quantidades de $\mathrm{pNF}^{-}$formado durante a reação.

Um ensaio de padronização desta relação foi realizado formando uma gota pendente de um meio reacional, contendo uma quantidade conhecida de TNAP (com atividade específica estimada por espectrofotometria tradicional), e registrando os valores de absorbância em função do tempo. Os resultados estão representados na Figura 41.
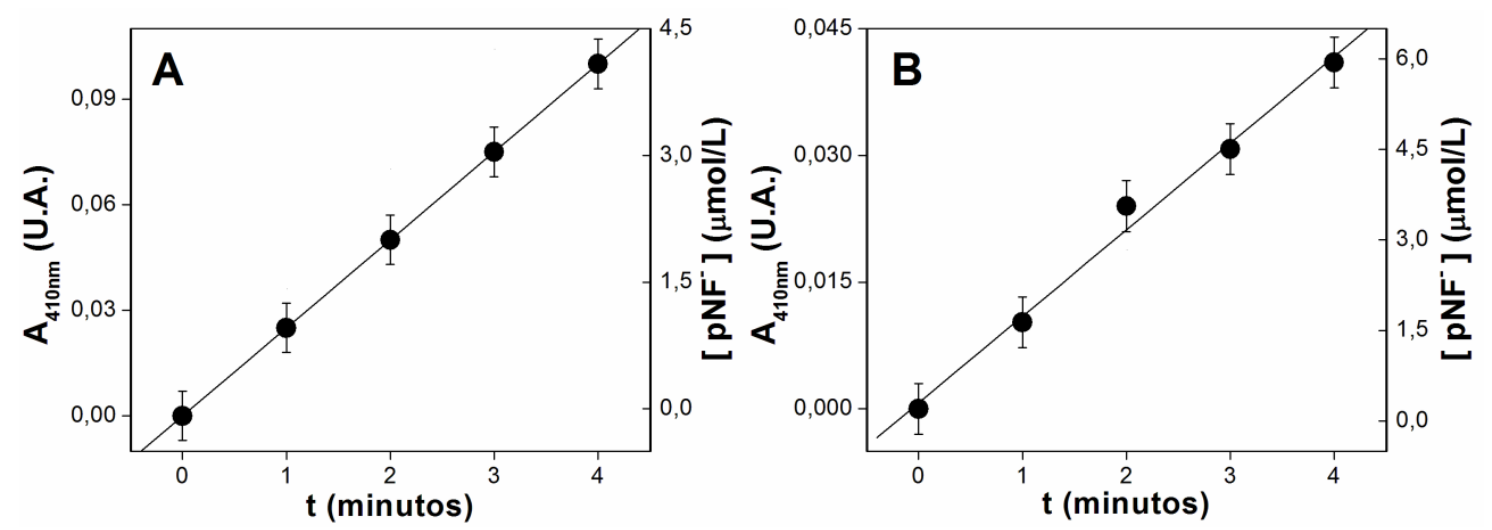

Figura 41 - Valores de absorbância e concentrações de $\mathrm{pNF}^{-}$no meio reacional contendo $0,528 \mu \mathrm{g}$ de TNAP (sem polidocanol) através de espectrofotometria tradicional em uma cubeta (A) e através de DRUV em uma gota pendente (B).

Observa-se que os valores de absorbância obtidos pelo método tradicional (Figura 41A, a partir dos quais se obtém a concentração de $\mathrm{pNF}^{-}$(por meio da lei de Lambert-Beer) não coincidem com aqueles obtidos por DRUV (Figura 41B). Desta

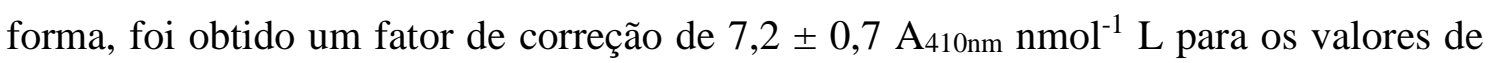
A410nm obtidos na gota pendente; permitindo a estimativa da concentração de pNF$^{-}$ produzida neste microambiente.

Desta forma, foi estimada a atividade específica da TNAP injetada em uma gota pendente de meio reacional. Os resultados deste ensaio estão representados na Figura 42 e na Tabela 6. Observa-se uma similaridade não só das atividades específicas 
(Tabela 6), como dos espectros obtido na metodologia tradicional com aquele obtido por DRUV (inserção da Figura 42A). O acréscimo nos valores da linha base dos espectros obtidos por reflectância difusa ocorrem devido evaporação da gota pendente; acréscimos estes descontados para obtenção dos valores de A410nm e cálculo da quantidade de $\mathrm{pNF}^{-}$produzido em função do tempo. Acoplando as duas metodologias é possível realizar uma medida simultânea de atividade cinética (DRUV) e superficial (ADSA) da enzima neste microambiente.
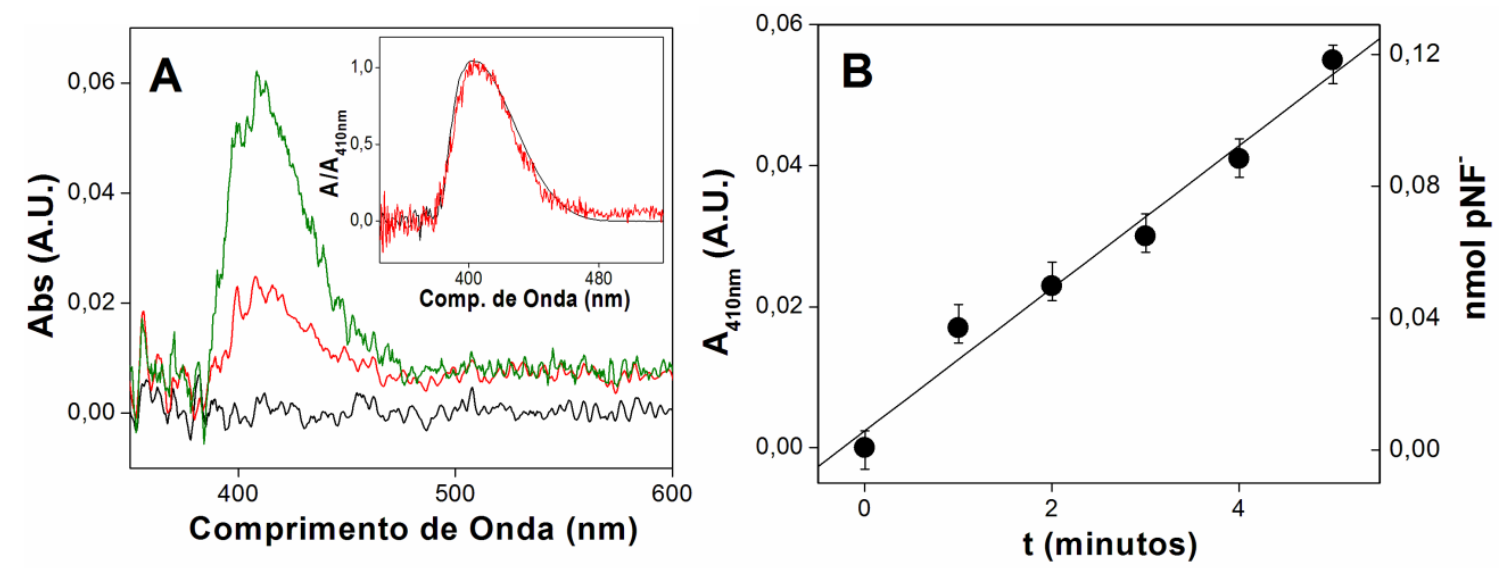

Figura 42 - Espectros UV-Vis do $\mathrm{pNF}^{-}$em intervalos de tempo de 0 (preto), 2 (vermelho) e 5 (verde) minutos após injeção de 13,2 ng de TNAP (sem polidocanol) em uma gota de meio reacional (A) e valores de absorção em $410 \mathrm{~nm}$ e quantidades de pNF$^{-}$ equivalentes a partir destes espectros. Inserção: espectros UV-Vis de pNFnormalizados, obtidos por espectrofotometria tradicional (preto) e por DRUV (vermelho).

\subsubsection{Imobilizada em Filmes LB}

Sob as mesmas condições descritas na seção 4.5.1, filmes LB de DMPA/Ca ${ }^{2+}$ com diferentes números de camadas foram construídos sobre suportes de quartzo para o ensaio de atividade fosfohidrolítica em meio reacional, sendo posteriormente expostos durante um período de 15 minutos em uma solução de TNAP 2,64 $\mu \mathrm{g} \mathrm{mL} \mathrm{mL}^{-1}$.

As atividades fosfohidrolíticas da TNAP fisicamente adsorvida nestes filmes estão representadas na Tabela 7 . Verifica-se que atividade da enzima imobilizada nos filmes LB é inversamente proporcional às densidades superficiais de enzima (determinadas por QCM), obtendo otimização dos valores de atividade nas condições de maiores áreas superficiais disponíveis por unidade de TNAP (Tabela 7). Este resultado é análogo à dados da literatura [108]. 
Considerando as dimensões da cadeia aminoacídica (formato de elipsoide com eixos de aproximadamente 50 e $100 \AA$ [68]), as condições nas quais a TNAP ocupa uma área molecular menor que $5000 \AA^{2}$ molécula $^{-1}$ indicam uma possível orientação que desfavoreça a efetiva atividade da enzima. Tal fato pode explicar as atividades dos filmes para $n=2$ e 4 serem menores que $1 \%$ em relação ao meio homogêneo, enquanto para $\mathrm{n}=3$ (A $\mathrm{A}_{\text {sup }}$ maior que a área molecular da TNAP) tal atividade corresponde a cerca de $6 \%$ em relação ao meio homogêneo. A exposição de cadeias hidrocarbônicas do DMPA para a solução permite interação hidrofóbica com a âncora GPI, promovendo uma orientação ótima da TNAP. Entretanto, em todas condições não foram obtidas atividades maiores que $10 \%$ em relação ao meio homogêneo. Esta redução de atividade corrobora com resultados obtidos em filmes DMPA $/ \mathrm{Zn}^{2+}$, nos quais a TNAP conserva cerca de $12 \%$ de sua atividade inicial [106]; seja por impedimento estérico, mudanças conformacionais durante a imobilização da enzima ou ainda por dificuldade de acesso do substrato ao sítio catalítico.

Tabela 7 - Valores de atividades específicas pNFFase $\left(A_{i m o b}\right)$, densidade superficial ( $\left.D_{\text {sup }}\right)$ e área molecular superficial ( $\mathrm{A}_{\text {sup }}$ ) da TNAP fisicamente adsorvida em filmes LB de DMPA/ $\mathrm{Ca}^{2+}$ com diferentes números de camadas, e comparação com a atividade em meio homogêneo $\left(\mathrm{A}_{\text {homog }}\right)$

\begin{tabular}{ccccc}
\hline $\begin{array}{c}\mathrm{N}^{\circ} \\
\text { Camadas }\end{array}$ & $\begin{array}{c}\mathrm{D}_{\text {sup }} \\
\left(\mathrm{ng} \mathrm{cm}^{-1}\right)\end{array}$ & $\begin{array}{c}\mathrm{A}_{\text {sup }} \\
\left(\AA^{2} \text { molécula }^{-1}\right)\end{array}$ & $\begin{array}{c}\text { Atividade } \\
\left(\mathrm{nmol} \mathrm{P}_{\mathrm{inin}} \mathrm{mg}^{-1}\right)\end{array}$ & $\begin{array}{c}\mathrm{A}_{\text {imob }} / \mathrm{A}_{\text {homog }} \\
(\%)\end{array}$ \\
\hline 4 & 689 & 3128 & $7,4 \pm 2,3$ & 0,3 \\
2 & 504 & 4275 & $16,2 \pm 5,4$ & 0,7 \\
3 & 342 & 6295 & $83,3 \pm 7,3$ & 6,3 \\
\hline
\end{tabular}

Sob as mesmas condições descritas na seção 4.5.2, filmes LB de DMPA/ $\mathrm{Ca}^{2+} /$ TNAP foram confeccionados a partir de monocamadas mistas. Foi transferido ao suporte sólido primeiramente uma monocamada de DMPA em subfase de $\mathrm{CaCl}_{2} 70 \mathrm{mmol} \mathrm{L}^{-1}$ e posteriormente foi realizada a deposição da $2^{\circ}$ camada a partir da monocamada mista, partindo de diferentes quantidades de TNAP.

Os valores de atividade pNFFase estão representados na Figura 43 e na Tabela 8. Verifica-se que a atividade fosfohidrolítica da TNAP imobilizada a partir da monocamada mista não apresentou proporcionalidade à quantidade de enzima espalhada na interface, mas apresentou maiores valores para maiores expansões de área das isotermas na pressão de deposição. Além disto, a atividade fosfohidrolítica da TNAP 
co-adsorvida mantém-se estável durante um intervalo de tempo próximo de 1 mês, como verificado através do valor constante de atividade pNFFase em função do tempo na Figura 43A. Este dado é importante, pois possibilita incubar as amostras contendo TNAP co-adsorvida em meios de formação de mineral em longos intervalos de tempo (garantindo que não haverá diminuição da atividade fosfohidrolítica com o tempo).
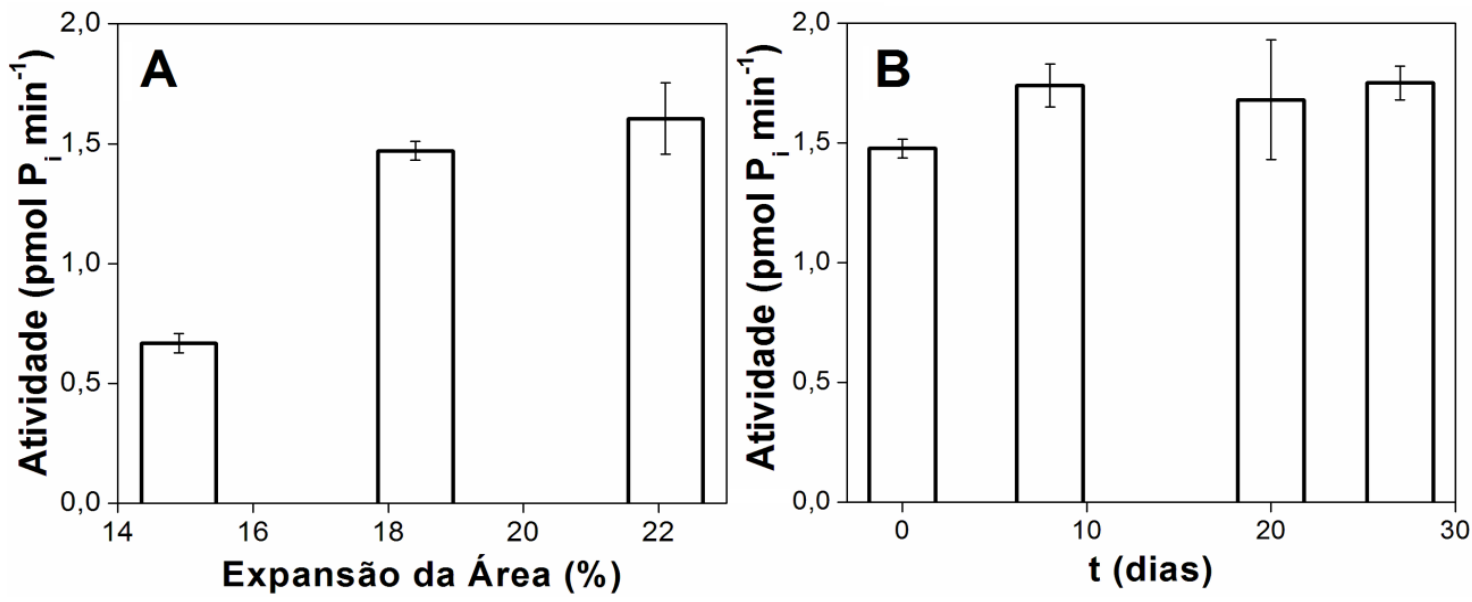

Figura 43 - Valores de atividade pNFFase de TNAP imobilizada em filmes LB mistos de TNAP/DMPA: em função das expansões provocadas pela enzima (em $\pi=30 \mathrm{mN} \mathrm{m}^{-}$ ${ }^{1}$ ) sobre as monocamadas de DMPA (A) e do filme construído a partir de monocamada de TNAP:DMPA 1:1400 em função do tempo (B).

Tabela 8 - Atividade fosfohidrolítica e parâmetros de deposição da TNAP imobilizada em filmes LB de DMPA/Ca ${ }^{2+}$ confeccionados a partir das monocamadas mistas contendo diferentes razões TNAP:DMPA

\begin{tabular}{cccc}
\hline $\begin{array}{c}\text { TNAP:DMPA } \\
(\mathrm{mol}: \mathrm{mol})\end{array}$ & $\begin{array}{c}\text { Atividade } \\
\left(\mathrm{pmol} \mathrm{P}_{\mathrm{i}} \mathrm{min}^{-1}\right)\end{array}$ & $\begin{array}{c}\text { Expansão }{ }^{*} \text { de Área } \\
(\%)\end{array}$ & $\mathrm{R}_{\text {trans. }}$ \\
\hline $1: 1400$ & $1,477 \pm 0,039$ & 18,41 & 0,94 \\
$1: 900$ & $0,667 \pm 0,005$ & 14,96 & 0,98 \\
$1: 680$ & $1,605 \pm 0,149$ & 22,15 & 1,07 \\
\hline
\end{tabular}

Uma maior expansão possivelmente indica uma maior quantidade de enzima presente na interface e transferida ao filme, explicando a maior atividade (Figura 43A). Além disto, tendo em vista que a partir dos dados de QCM representadas na Tabela 5 não é possível inferir o quanto de massa equivale à DMPA e o quanto equivale à TNAP, 
não foi possível representar as atividades específicas em cada caso (normalizadas por mg de enzima).

\subsection{Mineralização dos Filmes Mistos de DMPA/Ca ${ }^{2+} / T N A P$}

A análise cinética da TNAP foi realizada não só em meio homogêneo como também da enzima imobilizada nos filmes LB mistos, utilizando o substrato sintético pNFF para avaliar a atividade fosfohidrolítica nos diferentes sistemas. Para os ensaios de mineralização, por outro lado, o substrato no meio reacional é o ATP; servindo como fonte de $\mathrm{P}_{\mathrm{i}}$, que conjuntamente com os íons $\mathrm{Ca}^{2+}$ promoverão a formação de fosfatos de cálcio.

\subsubsection{Filmes Confeccionados Através de Adsorção Física de TNAP}

A fim de verificar a formação de minerais por turbidimetria em $340 \mathrm{~nm}$ foi utilizado um suporte circular de plástico, sobre o qual foram depositadas 4 camadas de DMPA/Ca ${ }^{2+}$ a partir de $\mathrm{CaCl}_{2} 0,1 \mathrm{mmol} \mathrm{L}{ }^{-1}\left(\mathrm{R}_{\text {trans }}\right.$ de 1,09$)$. Foi escolhido um número par de camadas $(n=4)$ tendo em vista o contato do final hidrofílico do filme LB com a solução de SCL. Este filme foi imerso por 15 minutos em solução de TNAP $(2,64 \mu \mathrm{g}$ $\left.\mathrm{mL}^{-1}\right)$.

A formação de minerais em meio de SCL, na ausência e presença de TNAP fisicamente adsorvida em filmes de DMPA/ $\mathrm{Ca}^{2+}$, está representada na Figura 44. Após um período de 6 e 9 dias, observa-se um aumento no valor de turbidez em $340 \mathrm{~nm}$, maior na incubação com os filmes contendo TNAP em relação aos filmes contendo apenas DMPA/ $/ \mathrm{Ca}^{2+}$; em concordância com a capacidade de TNAP imobilizada em induzir uma formação mais pronunciada de mineral, devido sua atividade fosfohidrolítica. 


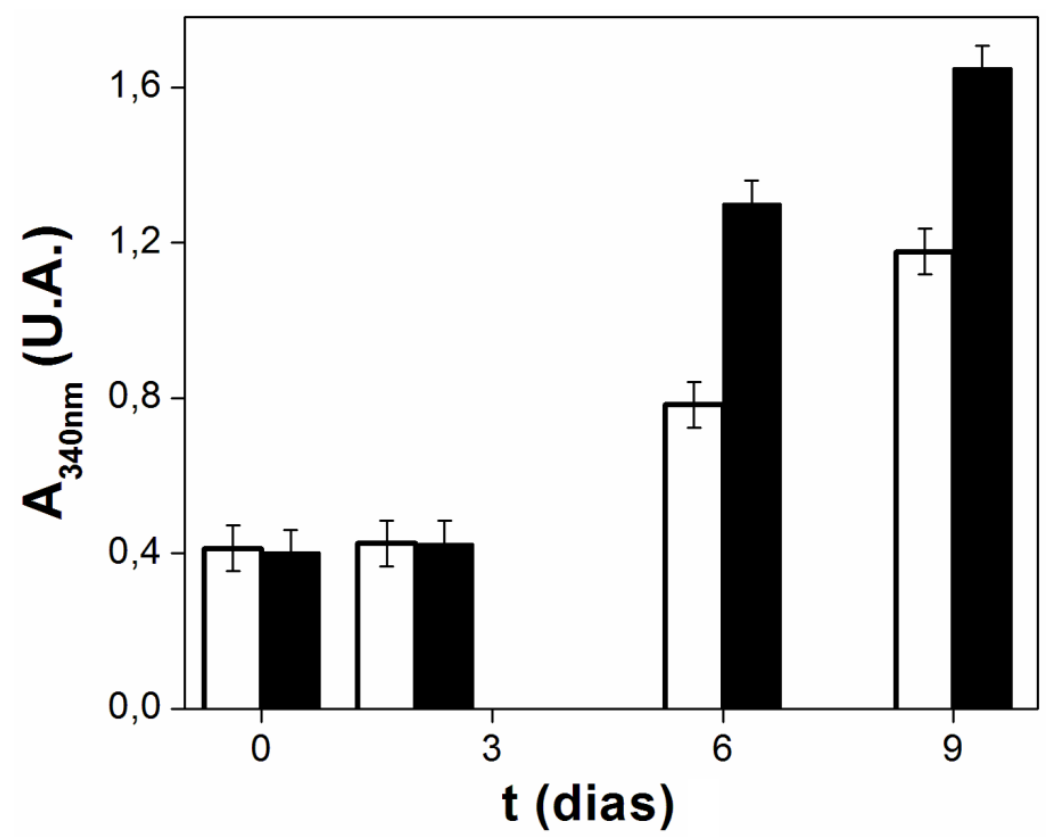

Figura 44 - Valores de absorbância em $340 \mathrm{~nm}$ do meio de SCL após exposição de filmes LB de DMPA/Ca ${ }^{2+}$ na ausência ( $\square$ ) ou presença (ロ) de TNAP fisicamente adsorvida.

Ainda por adsorção física, TNAP foi imobilizada sobre superfícies de $\mathrm{Ti}$ modificadas com filmes LB de DMPA/Ca ${ }^{2+} \operatorname{com} n=2$, com posterior exposição por 28 dias em SCL contendo gentamicina e fungizona. Após este intervalo de tempo, a morfologia da superfície foi caracterizada por microscopia eletrônica de varredura. As imagens obtidas estão representadas na Figura 45.

Observa-se a formação de partículas micrométricas nas amostras controle e naquelas contendo os filmes mistos DMPA/ $\mathrm{Ca}^{2+} / \mathrm{TNAP}$ (Figura 45), porém em maior quantidade por unidade de área nas superfícies contendo a enzima imobilizada; indicando que houve nucleação mais pronunciada nas superfícies recobertas com os filmes mistos. A ocorrência destas partículas nas amostras controle indica a formação de mineral na superfície destas, de acordo com o aumento dos valores de $A_{340 \mathrm{~nm}}$ na ausência de TNAP relatado na Figura 44, possivelmente atribuído a hidrólise espontânea do ATP favorecendo a nucleação de fosfatos de cálcio.

Não foi observado um recobrimento uniforme na superfície das amostras controle (Figura 45E), corroborando com a homogeneidade superficial observada na análise composicional (Figura 46A) e na presença apenas do sinal do elemento Ti no espectro de EDS (Figura 47A). A observação do aumento de turbidez destas amostras controle (Figura 44), somado à ausência de um recobrimento homogêneo na superfície 
modificada (Figura 45), indicam que há uma nucleação de mineral no seio da solução em detrimento do crescimento deste na superfície do suporte sólido.
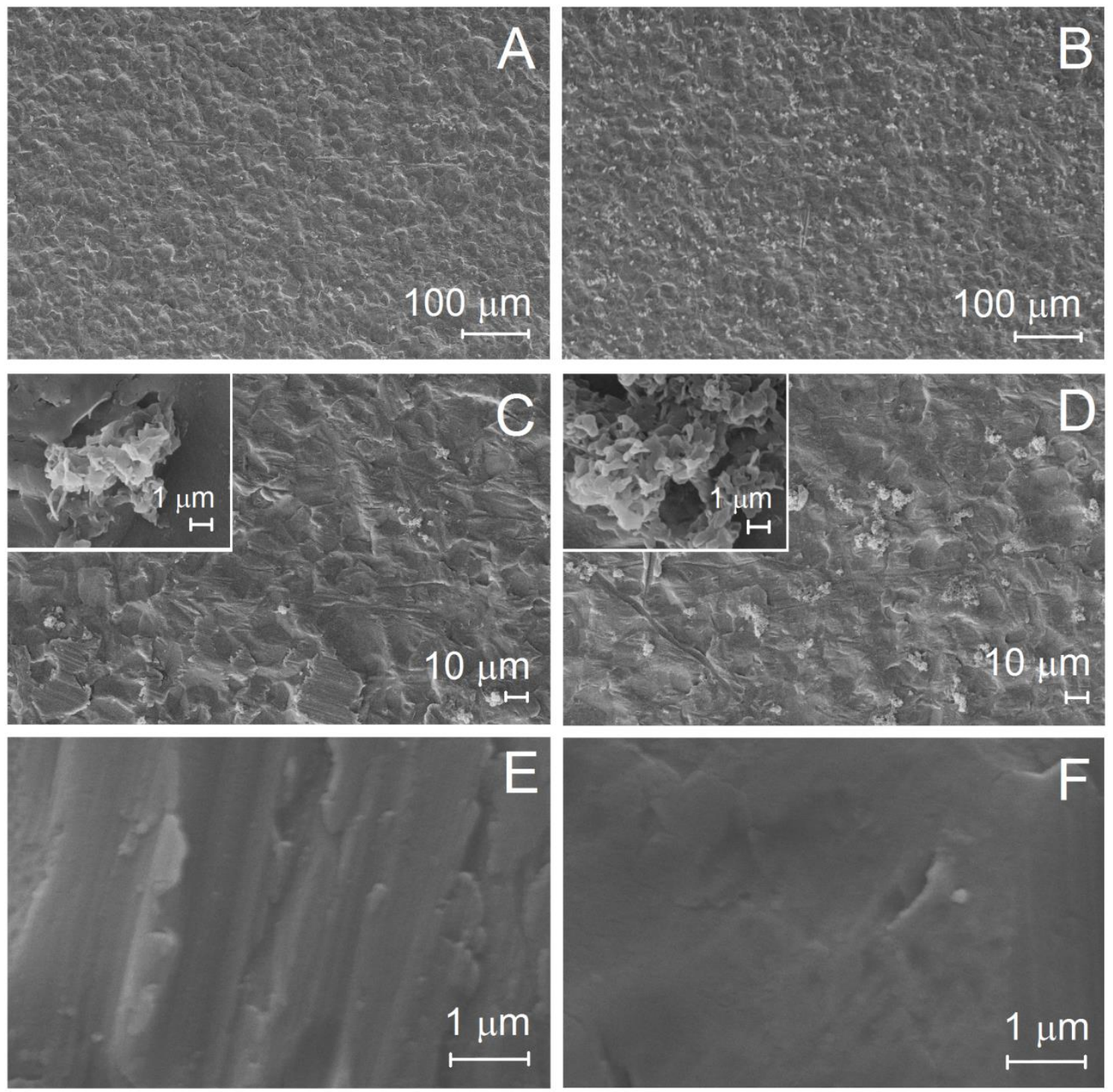

Figura 45 - Micrografias de MEV de superfícies de Ti modificadas com filmes LB de DMPA/ $\mathrm{Ca}^{2+}$ na ausência (A,C,E) e presença $(\mathrm{B}, \mathrm{D}, \mathrm{F})$ de TNAP fisicamente adsorvida, após 28 dias de exposição a SCL. Inserção (C,D): Detalhamento das partículas formadas na superfície.

Observa-se que a superfície das amostras contendo a enzima fisicamente adsorvida (Figura 45F) apresenta um recobrimento uniforme, indicando a formação de uma fase mineral devido à exposição ao SCL; similarmente ao observado para superfícies de Ti recobertas com filmes LB de um lipídeo negativamente carregado, após exposição a uma solução que induz a formação de um mineral [62]. O maior número de partículas formadas na superfície das amostras modificadas com os filmes contendo TNAP, somado às maiores dimensões em relação às partículas formadas nas 
amostras controle (como observado na inserção da Figura 45), indica formação de mineral em maior quantidade; que pode ser atribuída à atividade fosfohidrolítica da enzima, que também corrobora com o que fora observado para os valores de $A_{340 \mathrm{~nm}}$ (Figura 44). Observa-se, pela primeira vez, uma correlação direta entre os resultados obtidos no seio da solução que permite a mineralização (por turbidimetria) com a nucleação e crescimento de minerais na superfície de um substrato sólido (por técnicas espectroscópicas).

Ainda, para estas amostras contendo os filmes mistos DMPA/ $\mathrm{Ca}^{2+} / \mathrm{TNAP}$, observam-se regiões pontuais com composição distintas da superfície uniforme do Ti (Figura 46B). Estas regiões são compostas por fosfatos de cálcio, como indicado pelos sinais destes elementos nos espectros da Figura 47, juntamente com a presença de $\mathrm{C}$ e O.

Como foi verificada uma maior formação de minerais nas superfícies contendo TNAP imobilizada por turbidimetria (Figura 44), há uma concordância com a presença de P e Ca em regiões da superfície. Desta forma, na presença de TNAP, a nucleação e crescimento de mineral não é mais restrita somente no seio da solução (como indicado pelo aumento da turbidimetria em $340 \mathrm{~nm}$ ), ocorrendo também na interface sólidolíquido do Ti. A obtenção de diferentes razões $\mathrm{Ca} / \mathrm{P}$ (indicadas na Figura 47) indica que há a formação de fosfatos de cálcio com diferentes estequiometrias [161].
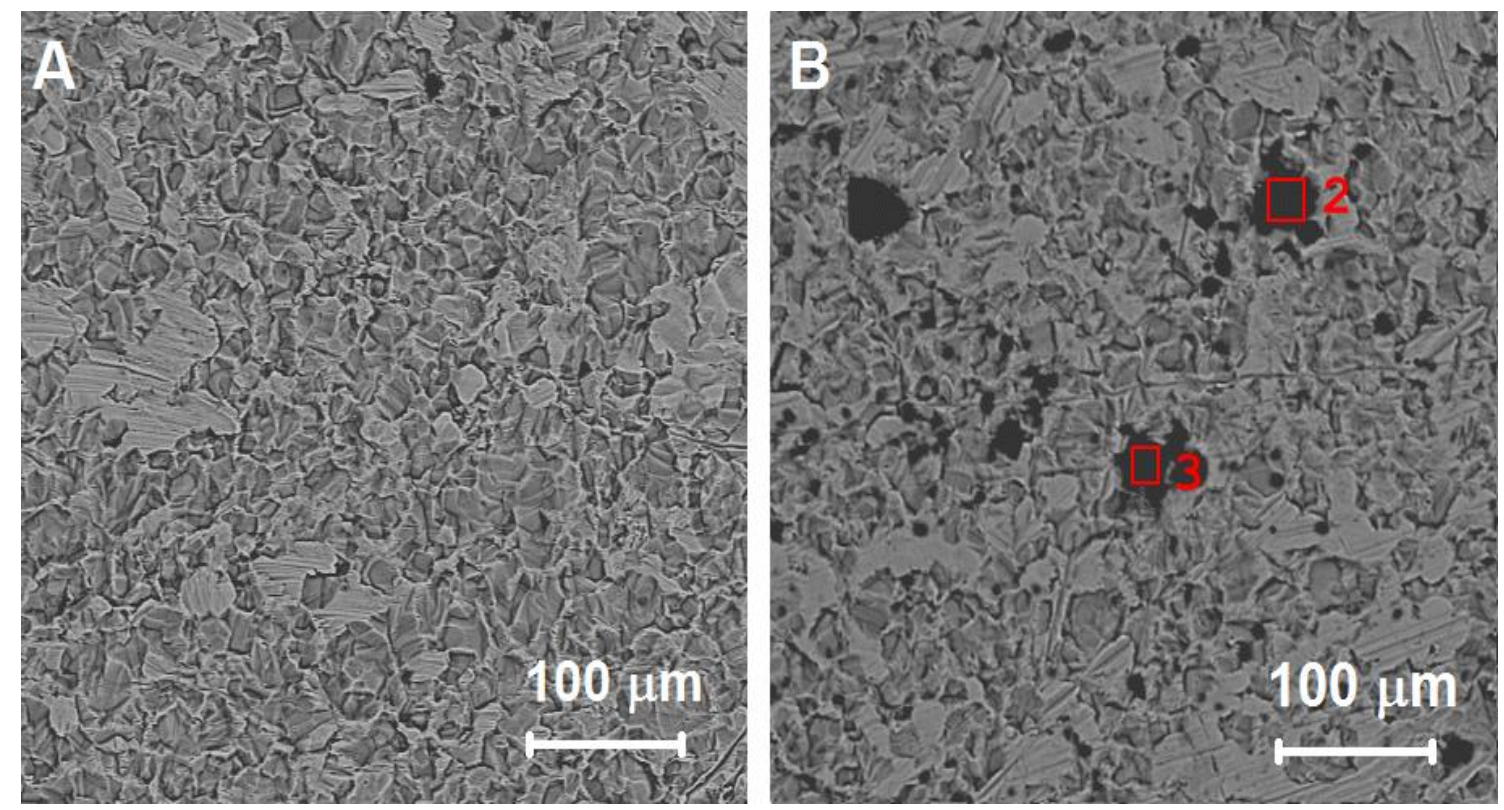

Figura 46 - Micrografias de MEV composicional de superfícies de Ti modificadas com filmes LB de DMPA/Ca ${ }^{2+}$ na ausência (A) e presença (B) de TNAP fisicamente adsorvida, após 28 dias de exposição a SCL. 


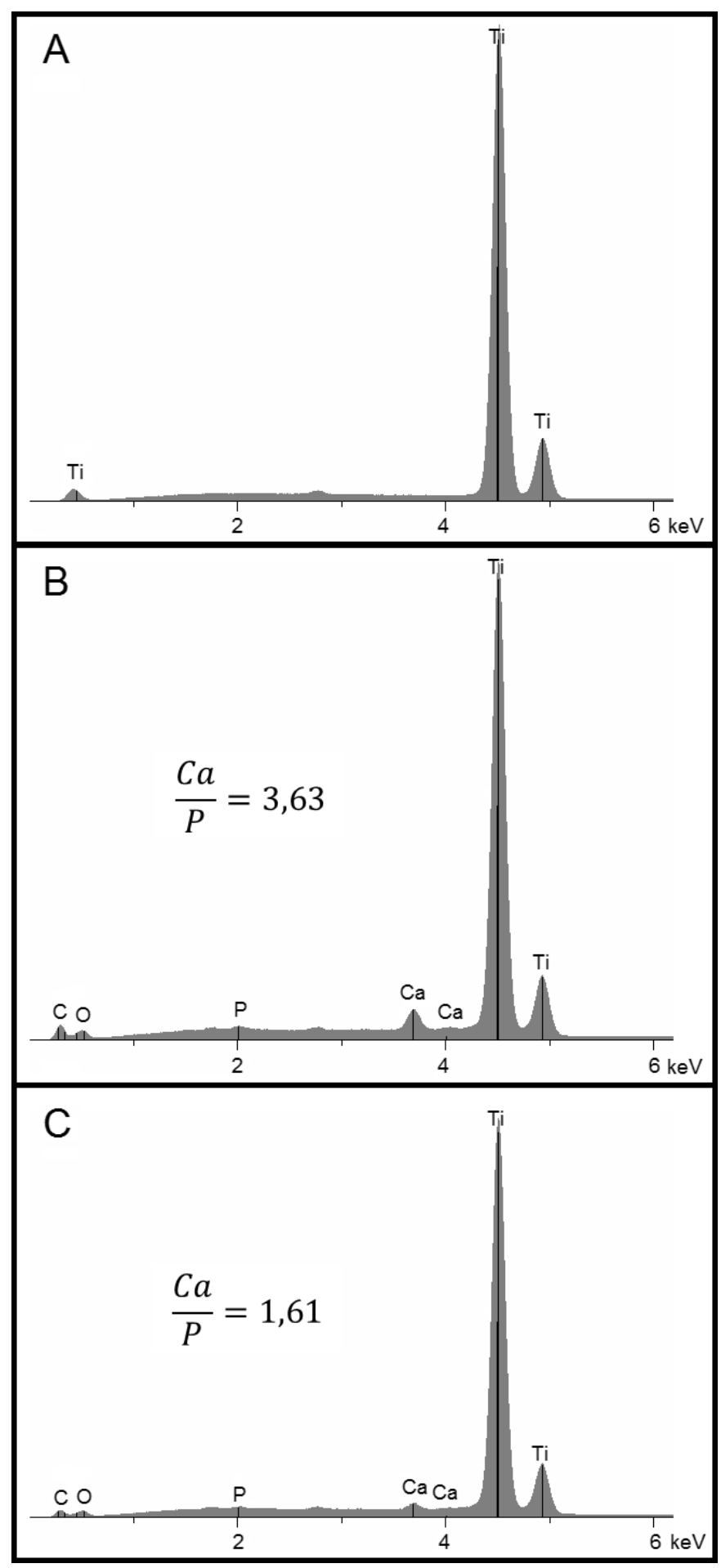

Figura 47 - Espectros de EDS das superfícies de Ti representadas na Figura 39: (A) referente à Figuras 46A, (B) e (C) referentes às regiões 2 e 3 da Figura 46B, respectivamente.

A análise composicional das superfícies de Ti modificadas foi realizada também por espectroscopia de infravermelho. Os espectros FTIR estão representados na Figura 48. Não há diferença significativa na diversidade de grupos funcionais presentes nas 
amostras controle (ausência de TNAP) em relação às amostras contendo a enzima fisicamente adsorvida, uma vez que ambos os espectros apresentam: bandas amplas de absorção entre 3000-3700 $\mathrm{cm}^{-1}$, atribuídas ao grupo $\mathrm{OH}$ de uma possível fase inorgânica ou devido à água adsorvida [162], bandas estreitas localizadas em 2920 e $2855 \mathrm{~cm}^{-1}$, correspondentes ao estiramento simétrico e assimétrico (respectivamente) dos grupos C-H [111], uma banda estreita em $1630 \mathrm{~cm}^{-1}$ correspondente à deformação angular da ligação O-H de moléculas de água adsorvidas [163] e uma banda estreita em $1030 \mathrm{~cm}^{-1}$ atribuída ao estiramento assimético $\left(v_{3}\right)$ do grupo fosfato [164].

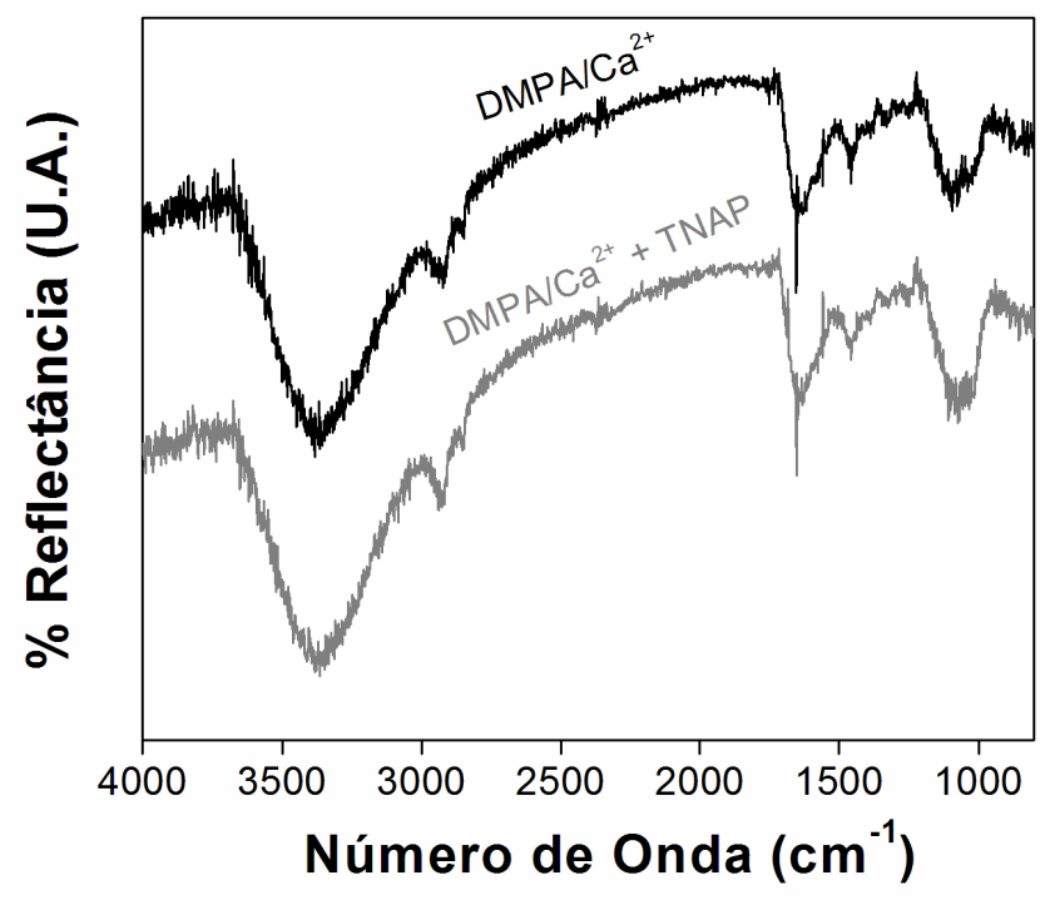

Figura 48 - Espectros de ATR-FTIR de superfícies de Ti modificadas com filmes LB de DMPA/ $\mathrm{Ca}^{2+}$ na ausência e presença de TNAP fisicamente adsorvida, após 28 dias de exposição a SCL.

Observa-se, porém, uma intensidade maior das bandas de estiramento de $\mathrm{C}-\mathrm{H}$ e $\mathrm{PO}_{4}{ }^{3-}$ para os filmes contendo a enzima adsorvida em relação aos filmes de DMPA/ $/ \mathrm{Ca}^{2+}$. A presença da cadeia aminoacídica da proteína ou dos fosfolipídeos que constituem o filme LB misto possivelmente intensificaram as bandas em 2920 e 2855 $\mathrm{cm}^{-1}$. A observação da banda de estiramento de $\mathrm{PO}_{4}{ }^{3-}$ nas superfícies modificadas com filmes LB de DMPA/Ca ${ }^{2+}$, tanto na ausência quanto na presença de TNAP, justifica-se pela presença das partículas micrométricas (possivelmente constituídas por fosfatos de cálcio) em ambas as condições; com uma intensificação da banda em $1030 \mathrm{~cm}^{-1}$ para as superfícies modificadas contendo a enzima, devido à indução de formação de mineral 
pela atividade fosfohidrolítica desta (corroborando com a presença de P no espectro de EDS).

Além da caracterização composicional por métodos espectroscópicos, as superfícies de Ti modificadas (após 28 dias de exposição ao SCL) foram analisadas por difração de raio X, obtendo os difratogramas representados na Figura 49.
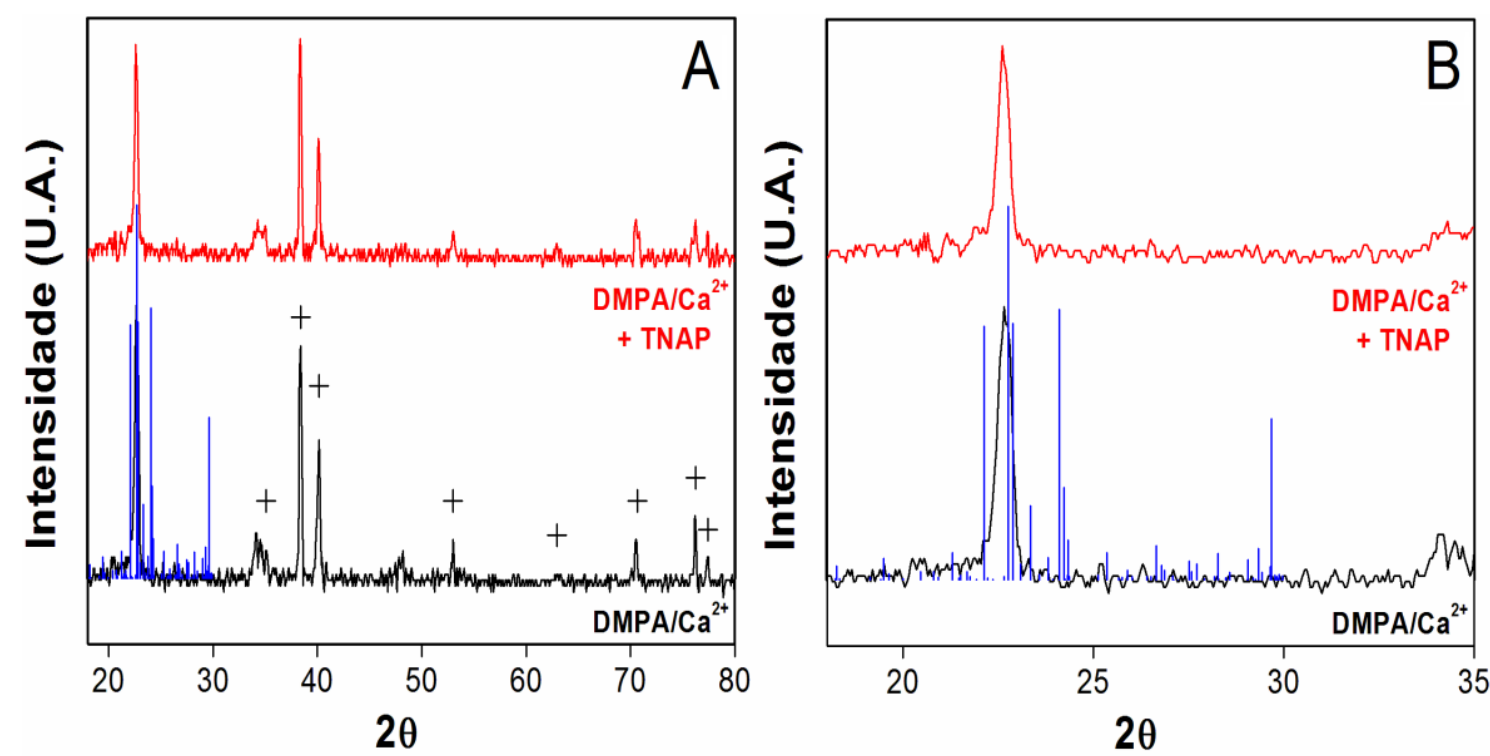

Figura 49 - Padrões de difração de: superfícies de Ti modificadas com filmes LB de DMPA/ $\mathrm{Ca}^{2+}$ na ausência (linha preta) e presença (linha vermelha) de TNAP fisicamente adsorvida, após 28 dias de exposição a SCL (A) e ampliação da região contendo picos relacionados ao mineral e comparação com os picos presentes no padrão de difração de $\mathrm{Ca}_{3} \mathrm{PO}_{4}$ (linha azul). Os picos marcados com + correspondem ao suporte de Ti.

O padrão de difração obtido corresponde aos padrões de titânio (AMCSD 0011195), tanto nas amostras controle quanto nas amostras contendo TNAP adsorvida. Ainda, observa-se um pico em $2 \theta=23^{\circ}$, o qual indica a presença de uma fase mineral de $\mathrm{Ca}_{3}\left(\mathrm{PO}_{4}\right)_{2}$, cujo pico principal do padrão de difração situa-se neste valor de $2 \theta$ (COD 96-210-6195), de acordo com o sinal de $\mathrm{Ca}$ e $\mathrm{P}$ e com a razão $\mathrm{Ca} / \mathrm{P}$ próximo de 1,6 (enquanto que a razão para $\mathrm{Ca}_{3}\left(\mathrm{PO}_{4}\right)_{2}$ corresponde a 1,5) obtidos nos espectros de EDS (Figura 47).

Como foi obtido um recobrimento homogêneo apenas para as amostras modificadas com os filmes contendo a TNAP, enquanto o pico correspondente à fase mineral está presente em ambos os difratogramas, as partículas micrométricas formadas na superfície das amostras possivelmente são constituídas de $\mathrm{Ca}_{3}(\mathrm{PO} 4)_{2}$; uma vez que 
esta fase mineral, bem como as partículas micrométricas, estão presente tanto nas amostras controle quanto naquelas contendo a enzima.

\subsubsection{Filmes Confeccionados a Partir das Monocamadas Mistas de DMPA/TNAP}

Sob as mesmas condições descritas na seção 4.5.2, filmes LB mistos de DMPA/ $\mathrm{Ca}^{2+} /$ TNAP foram confeccionados sobre discos de Ti, visando a modificação superficial para aumento de bioatividade. Bicamadas de DMPA/Ca ${ }^{2+}$ foram transferidas ao filme $\left(\mathrm{R}_{\text {trans }}\right.$ de 1,15$)$, com a TNAP imobilizada na $2^{\circ}$ camada, a partir de monocamadas contendo diferentes razões molares TNAP:DMPA.

A formação de minerais em meio de SCL, na ausência e presença de TNAP coadsorvida em filmes de DMPA/Ca ${ }^{2+}$, está representada através do aumento dos valores

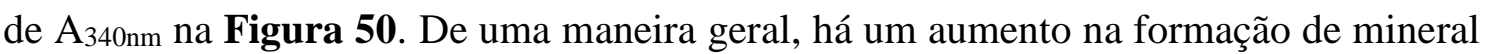
nos meios incubados com filmes na presença de TNAP; aumento este mais pronunciado para os filmes confeccionados a partir de menores razões molares de TNAP:DMPA.

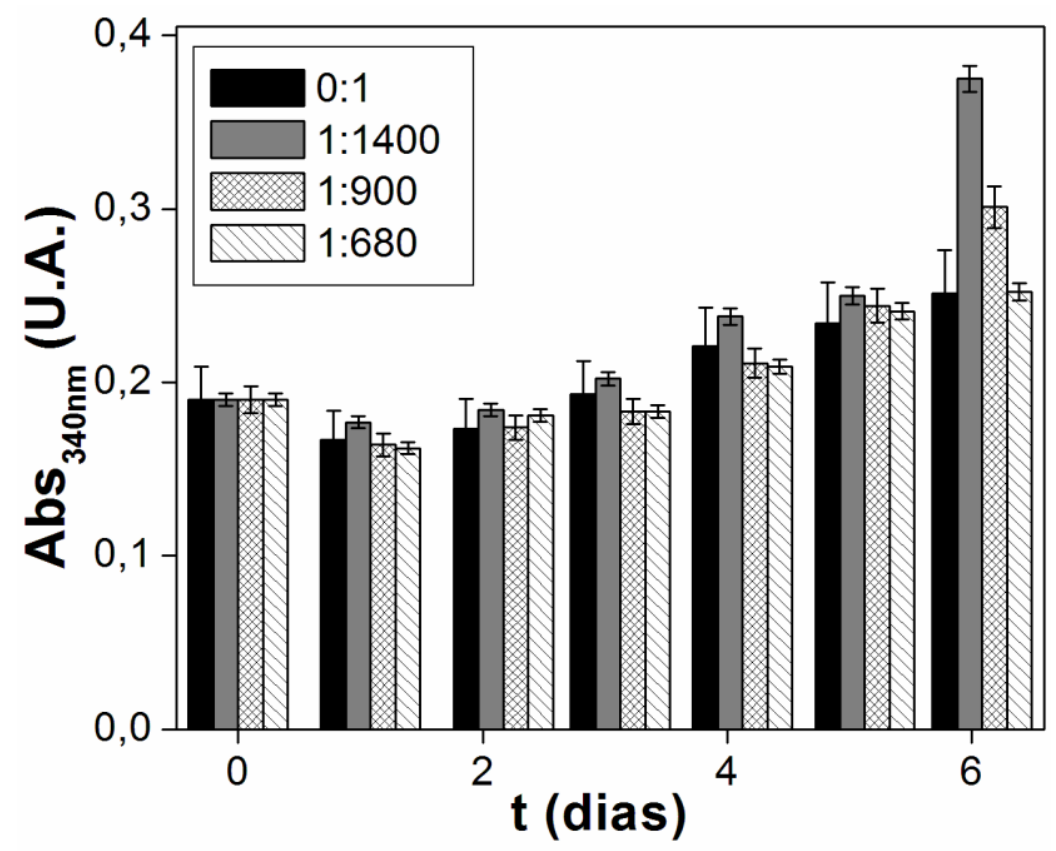

Figura 50 - Valores de absorbância em 340 nm do meio de SCL após exposição de filmes $\mathrm{LB}$ de DMPA/Ca ${ }^{2+}$ na ausência ou presença de diferentes razões molares TNAP:DMPA (indicadas na figura) sobre subfase de $\mathrm{CaCl}_{2} 70 \mathrm{mmol} \mathrm{L}^{-1}$.

Em comparação com a condição de TNAP fisicamente adsorvida, os filmes LB com a enzima imobilizada por meio da transferência das monocamadas mistas 
apresentaram uma indução de mineralização menos pronunciada (menores valores de $\mathrm{A}_{340 \mathrm{~nm}}$ dentro do mesmo intervalo de tempo de análise), assim como a atividade fosfohidrolítica destes (na ordem de pmol $\mathrm{P}_{\mathrm{i}} \min ^{-1}$ ) também foi muito reduzida frente à atividade daqueles (na ordem de $\mu \mathrm{mol} \mathrm{P}_{\mathrm{i}} \min ^{-1}$ ). Possivelmente, a presença de alta concentração de íons $\mathrm{Ca}^{2+}$ na subfase (durante a confecção dos filmes a partir das monocamadas mistas) favoreceu a ligação deste íon em sítios específicos na enzima, diminuindo sua atividade fosfohidrolítica e, portanto, a capacidade de indução de mineralização da enzima imobilizada.

Após a exposição ao SCL, a morfologia das amostras foi avaliada por MEV, obtendo as imagens representadas na Figura 51. Partículas nanométricas foram formadas na superfície das amostras contendo TNAP imobilizada (Figura 51B e D), ausentes nos filmes de DMPA/Ca ${ }^{2+}$ (Figura 51A e C). A co-adsorção de uma maior quantidade de íons $\mathrm{Ca}^{2+}$ (evidenciada na Figura 23, pelo aumento de massa no filme, devido subfase mais concentrada de $\mathrm{CaCl}_{2} 70 \mathrm{mmol} \mathrm{L}^{-1}$ ) não é suficiente para induzir a formação de mineral na superfície, sendo necessário também induzir um aumento na concentração de íons $\mathrm{PO}_{4}{ }^{3-}$ na interface sólido-líquido, garantida pela atividade fosfohidrolítica da enzima presente no filme LB.
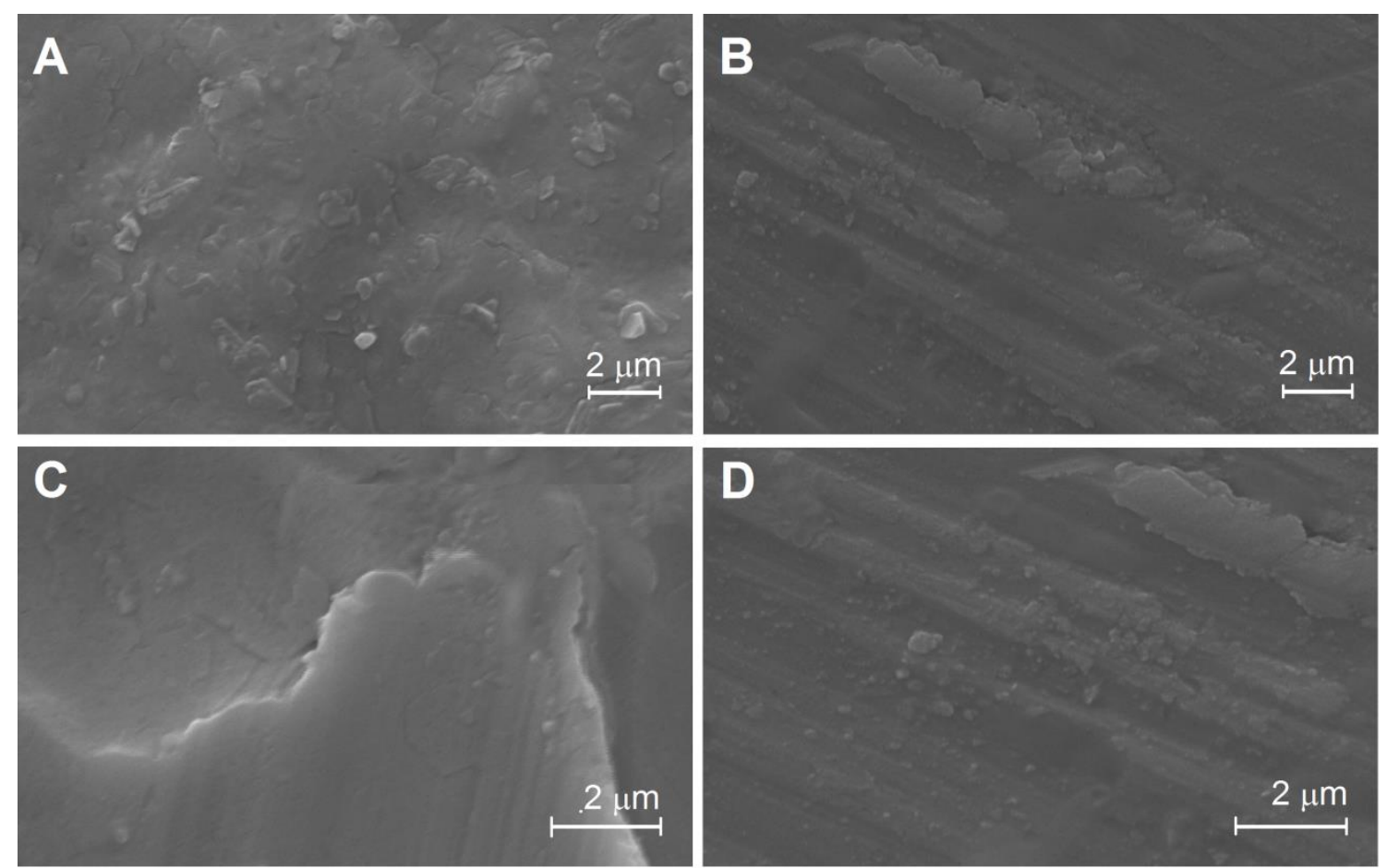

Figura 51 - Micrografias de MEV de superfícies de Ti modificadas com filmes LB de DMPA $/ \mathrm{Ca}^{2+}$ na ausência $(A, C)$ e presença $(B, D)$ de TNAP imobilizada a partir de monocamada mista de TNAP:DMPA 1:900, após 6 dias de exposição a SCL. 
Observa-se que a modificação com o filme misto DMPA/Ca ${ }^{2+} /$ TNAP promove a formação destas partículas de maneira não uniforme na superfície do Ti, através da análise composicional representada na Figura 52, a qual apresenta uma composição homogênea (correspondente ao Ti) e regiões pontuais com composição distinta; contendo, segundo o espectro representado na Figura 53, elementos como $\mathrm{P}$ e $\mathrm{O}$ (possivelmente oriundo de grupos $\mathrm{PO}_{4}{ }^{3-}$ ), $\mathrm{C}$ (oriundo de grupos $\mathrm{CO}_{3}{ }^{2-}$ ou ainda de cadeias hidrocarbônicas do fosfolipídeo), contendo ainda $\mathrm{Cl}, \mathrm{Mg}$ e $\mathrm{S}$, possivelmente oriundos de íons de sais precipitados sobre a superfície.

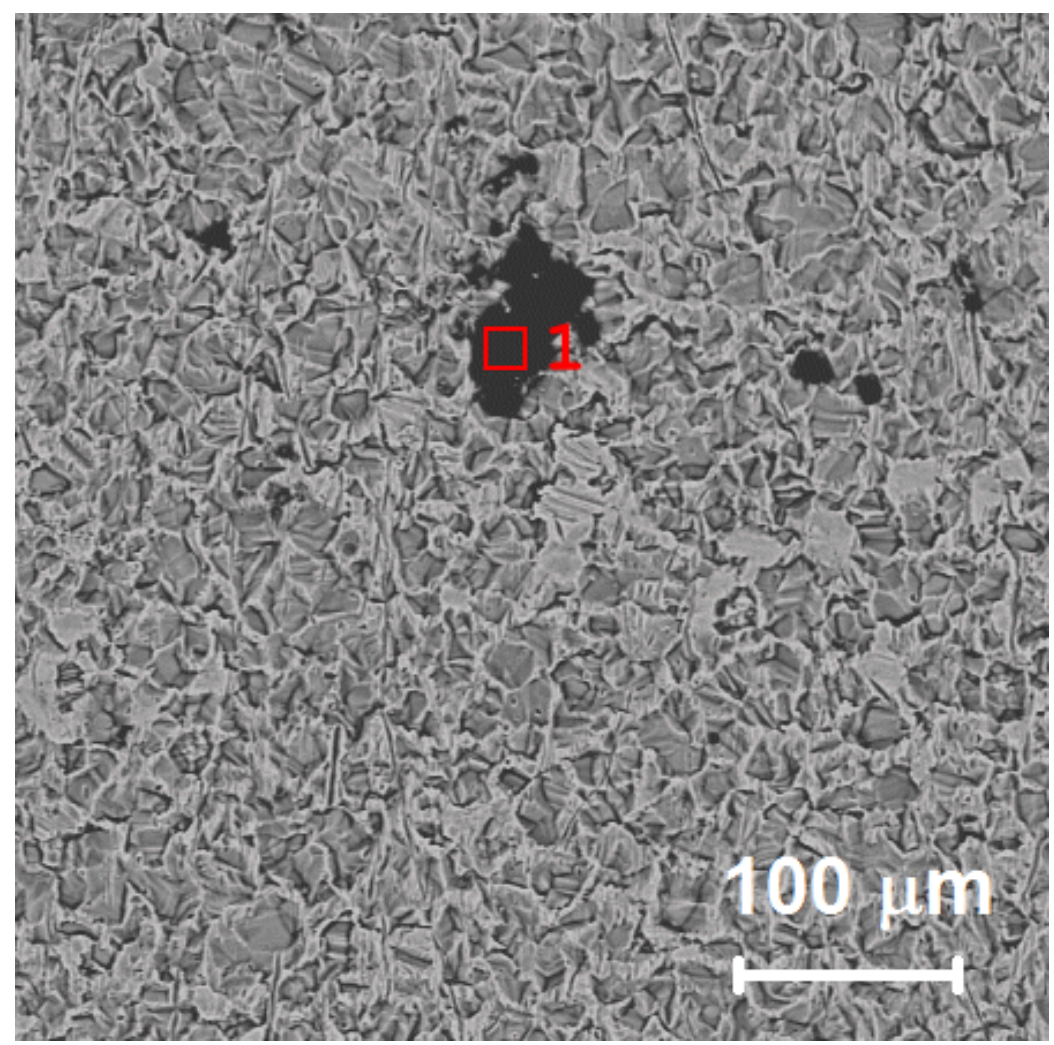

Figura 52 - Micrografia de MEV composicional de superfície de Ti modificada com filme LB de DMPA/Ca ${ }^{2+}$ na presença de TNAP imobilizada a partir de monocamada mista de TNAP:DMPA 1:900, após 6 dias de exposição a SCL.

Ainda em uma análise composicional, verifica-se a presença dos mesmos grupos funcionais obtidos para os filmes contendo TNAP fisicamente adsorvida, através dos espectros de ATR-FTIR representados na Figura 54. Porém, nota-se que a banda de absorção em $1030 \mathrm{~cm}^{-1}$ apresenta uma intensidade mais pronunciada nas amostras que contêm TNAP imobilizada; uma diferença mais notável do que aquela verificada na Figura 48, indicando que houve efetivamente a formação de uma fase mineral de 
fosfato, corroborando com o intenso sinal de $\mathrm{P}$ verificado na Figura 53 (em determinadas regiões da superfície modificada).

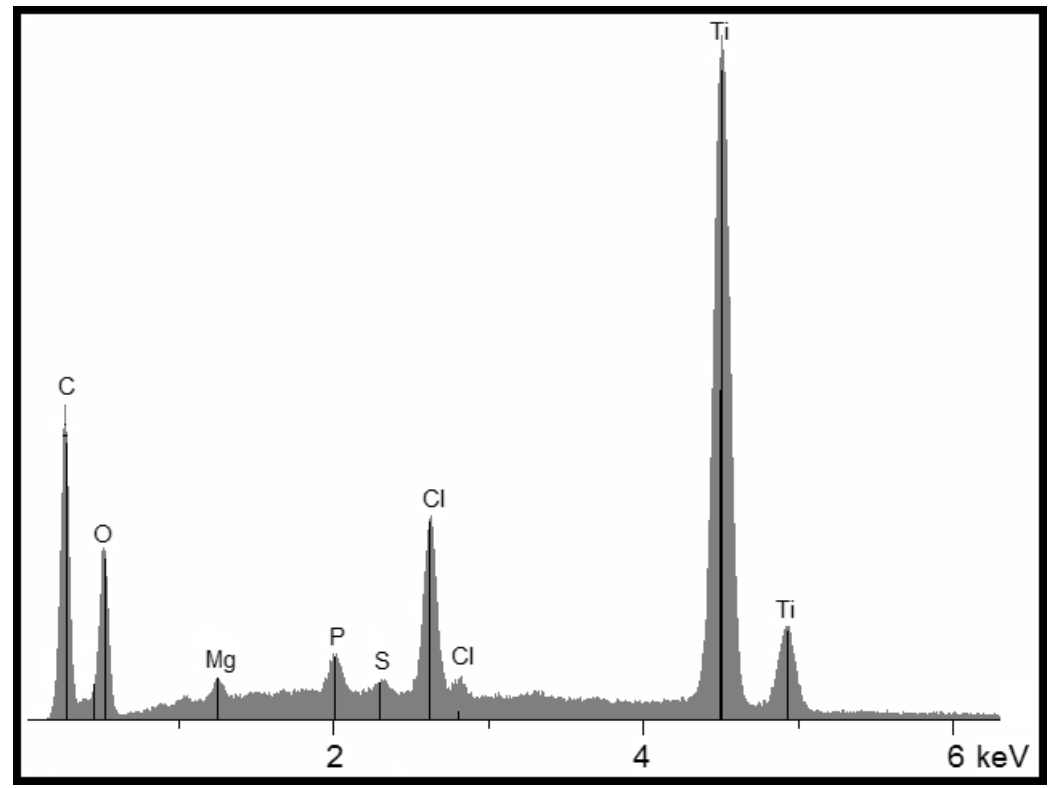

Figura 53 - Espectro de EDS da superfície de Ti, referente à região 1 representada na Figura 52.

Além disto, houve uma diminuição da intensidade desta banda de $\mathrm{PO}_{4}{ }^{3-}$ com o aumento das razões molares TNAP:DMPA, de maneira análoga ao que fora verificado para os valores de $\mathrm{A}_{340 \mathrm{~nm}}$ no $6^{\circ}$ dia de incubação em SCL (Figura 50), apresentando menores intensidades para amostras confeccionadas a partir de monocamadas com maiores razões TNAP:DMPA; demonstrando, mais uma vez, uma correlação direta entre a nucleação de mineral no interior da solução e o crescimento deste na superfície de Ti modificada.

Mais uma vez evidencia-se a importância da indução de formação de uma fase mineral devido à geração local de íons $\mathrm{PO}_{4}{ }^{3-}$, atribuída graças à atividade fosfohidrolítica da TNAP. Apesar da atividade pNFFase da TNAP fisicamente adsorvida (Tabela 7) ser cerca de $10^{3}$ vezes maior que aquela obtida nos filmes mistos (Figura 43), é necessário um intervalo de tempo cerca de 5 vezes maior (em relação aos filmes mistos) para estes induzirem a formação de fosfatos de cálcio na superfície de Ti.

Esta diferença possivelmente é decorrência das condições de deposição, uma vez que a metodologia baseada na adsorção física parte de uma subfase de $\mathrm{CaCl}_{2}$ mais diluída que aquela utilizada na formação do filme misto. Desta forma, os filmes confeccionados a partir de subfase de $\mathrm{CaCl}_{2}$ mais concentrada pode ter favorecido uma 
maior co-adsorção destes íons (favorecendo a nucleação e crescimento de mineral). Ressaltando que utiliza-se uma concentração deste sal na subfase a fim de atingir um estado de força iônica que permite a co-adsorção do sistema misto TNAP/DMPA (Figura 30).

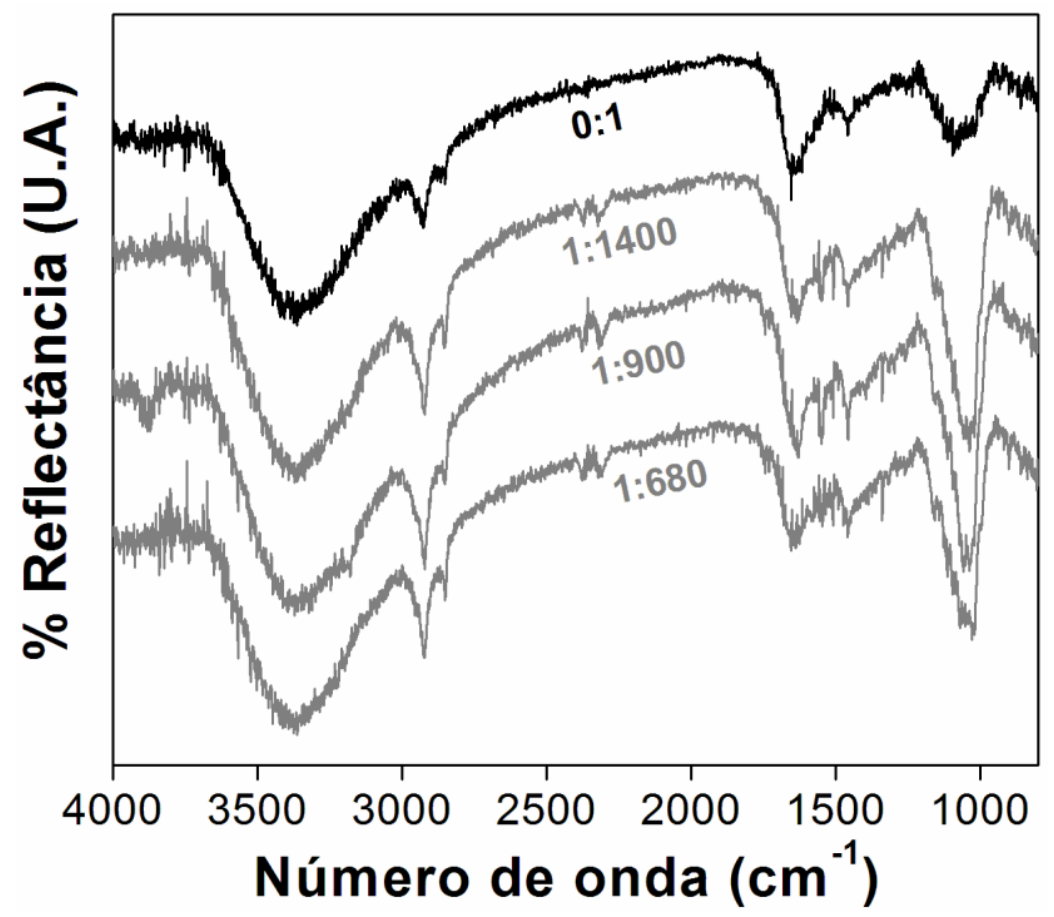

Figura 54 - Espectros de ATR-FTIR de superfícies de Ti modificadas com filmes LB de DMPA/Ca ${ }^{2+}$ na ausência ou presença de TNAP imobilizada a partir de monocamadas mistas com diferentes razões molares TNAP:DMPA (indicadas na figura), após 6 dias de exposição a SCL.

Apesar da análise composicional por EDS e ATR-FTIR indicar a formação de uma fase mineral de fosfato, a análise por DRX das amostras na ausência e presença de TNAP indicou apenas padrões de difração correspondentes à superfície de Ti, como verifica-se nos difratogramas na Figura 55. Vale a pena ressaltar que o equipamento utilizado não possui acessório para a análise de filmes finos, o que possivelmente inviabilizou a detecção de uma fase mineral de fosfato.

Além da composição química, observam-se mudanças significativas nas propriedades superficiais das amostras contendo a TNAP após 6 dias de exposição ao SCL, como observado pelos dados Tabela 9. Após a exposição ao SCL, o filme DMPA/ $\mathrm{Ca}^{2+}$, por apresentar um final hidrofílico, devido à orientação das cabeças polares do lipídeo para a região externa do filme, provocou uma diminuição do ângulo de contato $(\mathrm{AC})$ da água em relação à superfície não-modificada (nem exposta ao SCL) 
de $\mathrm{Ti}$, indicando um aumento da hidrofilicidade da superfície, que é refletido em aumento também da componente polar $\left(\gamma_{\mathrm{P}}\right)$ da energia superficial total (que praticamente não sofreu modificação).

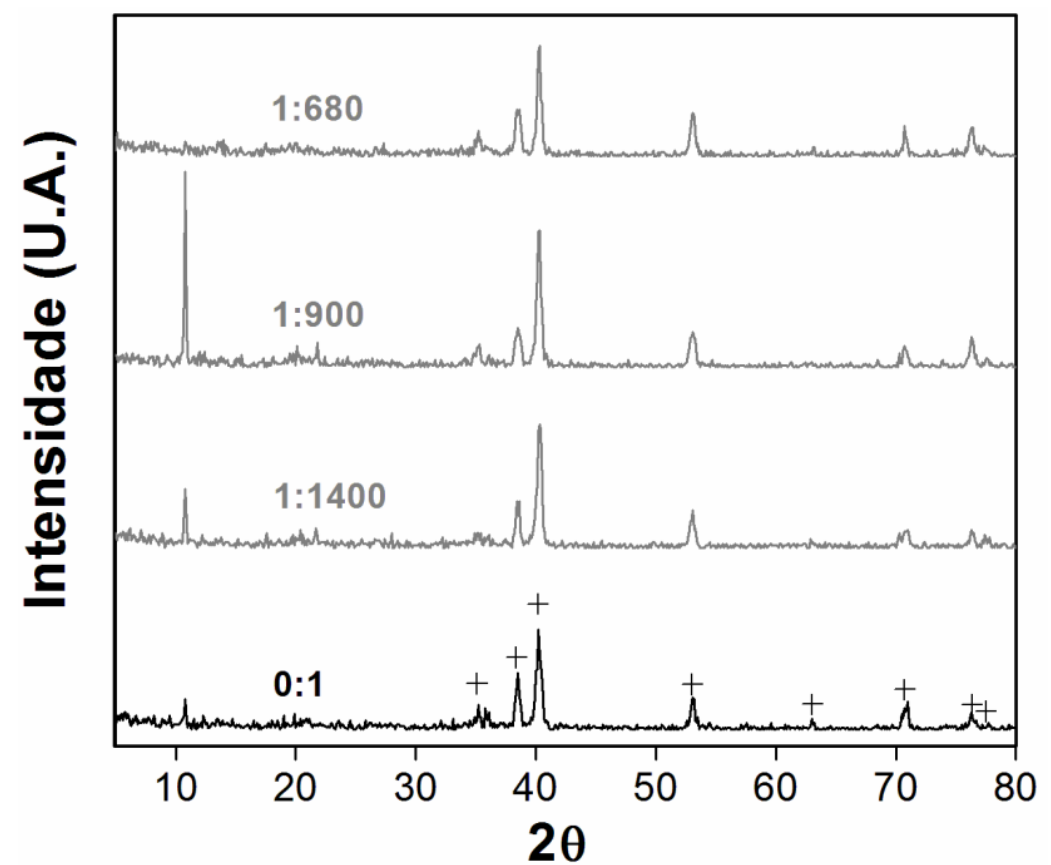

Figura 55 - Padrões de difração de superfícies de Ti modificadas com filmes LB de DMPA/ $\mathrm{Ca}^{2+}$ na ausência ou presença de TNAP imobilizada a partir de monocamadas mistas com diferentes razões molares TNAP:DMPA (indicadas na figura), após 6 dias de exposição a SCL.

Tabela 9 - Ângulo de contato de água (AC), energia livre de superfície $\left(\gamma_{S}\right)$ e suas componentes polar $\left(\gamma_{\mathrm{P}}\right)$ e dispersiva $\left(\gamma_{\mathrm{D}}\right)$ de superfícies de Ti modificadas com filmes LB de DMPA/Ca ${ }^{2+}$ na ausência ou presença de TNAP imobilizada a partir de monocamadas mistas com diferentes razões molares TNAP:DMPA, após 6 dias de exposição a SCL

\begin{tabular}{ccccc}
\hline $\begin{array}{c}\text { Razão Molar } \\
\text { TNAP:DMPA }\end{array}$ & $\begin{array}{c}\mathrm{AC} \\
\left({ }^{\circ}\right)\end{array}$ & $\begin{array}{c}\gamma_{\mathrm{S}} \\
\left(\mathrm{mJ} \mathrm{m}^{-2}\right)\end{array}$ & $\begin{array}{c}\gamma_{\mathrm{P}} \\
\left(\mathrm{mJ} \mathrm{m}^{-2}\right)\end{array}$ & $\begin{array}{c}\gamma_{\mathrm{D}} \\
\left(\mathrm{mJ} \mathrm{m}^{-2}\right)\end{array}$ \\
\hline $\mathrm{Ti}^{*}$ & $72,15 \pm 0,9$ & $38,0 \pm 1,8$ & $10,7 \pm 0,9$ & $27,3 \pm 1,6$ \\
$0: 1$ & $65,4 \pm 0,9$ & $39,6 \pm 0,7$ & $28,9 \pm 0,5$ & $10,6 \pm 0,4$ \\
$1: 1400$ & $53,3 \pm 0,8$ & $48,2 \pm 0,7$ & $21,2 \pm 0,6$ & $27,0 \pm 0,3$ \\
$1: 900$ & $51,8 \pm 0,5$ & $43,4 \pm 0,7$ & $17,5 \pm 0,4$ & $25,9 \pm 0,5$ \\
$1: 680$ & $65,9 \pm 0,3$ & $42,4 \pm 1,3$ & $13,5 \pm 0,5$ & $29,2 \pm 1,1$
\end{tabular}


Já na presença de TNAP, observa-se um aumento mais expressivo de $\gamma_{\mathrm{S}}$ (em conjunto com um aumento na hidrofilicidade superficial indicada pela diminuição do AC), devido um aumento na $\gamma_{P}$ (sem modificação significativa na $\gamma_{D}$ ). Este efeito pode estar relacionado com a presença de uma fase mineral, induzida pela presença da TNAP, formada sobre a superfície de Ti.

O aumento na razão molar TNAP:DMPA (na monocamada que deu origem aos filmes mistos) provocou uma diminuição nos valores de $\gamma_{\mathrm{P}} \mathrm{e}$, consequentemente, nos valores de $\gamma_{\mathrm{s}}$, até apresentar um AC (na razão molar 1:680) similar ao observado para a superfície exposta ao SCL modificada apenas com DMPA/Ca ${ }^{2+}$. Este comportamento também foi observado para as intensidades da banda de $1030 \mathrm{~cm}^{-1}$ de ATR-FTIR (Figura 54) e dos valores de $\mathrm{A}_{340}$ no $6^{\circ}$ dia de incubação no SCL (Figura 50), que indicam uma menor formação de fase mineral para os filmes LB confeccionados a partir de maiores razões molares TNAP:DMPA (explicando tais diferenças nas propriedades superficiais das amostras contendo a enzima).

\subsection{Cultivo de Osteoblastos sobre os Filmes de DMPA/Ca ${ }^{2+} / T N A P$}

Mais uma vez, sob as mesmas condições descritas na seção 4.5.2, filmes LB mistos de DMPA/Ca ${ }^{2+} / \mathrm{TNAP}$ foram confeccionados transferindo bicamadas de DMPA/ $/ \mathrm{Ca}^{2+}$ sobre discos de Ti, com a TNAP imobilizada na $2^{\circ}$ camada (a partir da monocamada mista de TNAP:DMPA 1:1400). O final do filme com a cabeça polar do lipídeo garante hidrofilicidade ao mesmo; fator importante na viabilidade celular durante o crescimento de células osteogênicas.

A fim de avaliar o efeito da modificação superficial no comportamento de osteoblastos (sobretudo, se a presença da enzima no template do filme LB promove sinalização para a proliferação), foi realizado um cultivo sobre as superfícies de Ti, na ausência e presença de filmes de DMPA/Ca ${ }^{2+}$ (contendo ou não TNAP imobilizada a partir da monocamada mista). Os resultados obtidos estão apresentados na Figura 56.

Como as propriedades de adesão celular inicial sobre a superfície modificada eram o foco deste estudo, tal ensaio de viabilidade celular foi restrito até o $10^{\circ}$ dia. Observa-se que não há diferença significativa na proliferação das células osteogênicas cultivadas sobre a superfície de Ti modificadas com os filmes LB (com ou sem TNAP) em relação ao controle de Ti limpo. Observa-se um mínimo de viabilidade no $7^{\circ}$ dia de cultivo e posteriormente um pequeno acréscimo desta no $10^{\circ}$ dia de cultivo. Resultados 
semelhantes foram observados para superfícies de Ti modificadas com filmes LB híbridos (contendo uma fase mineral), devido a influência dos íons $\mathrm{Ca}^{2+}$ co-adsorvidos no filme, com uma posterior recuperação de viabilidade [62].

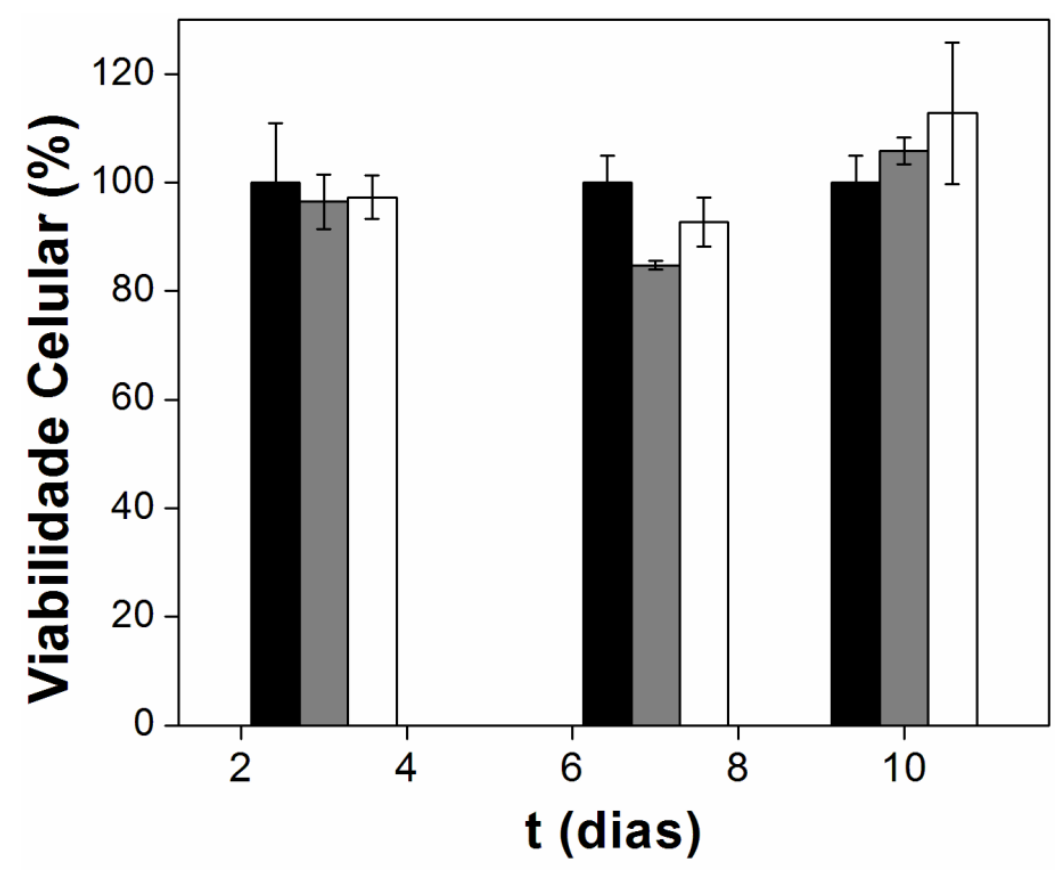

Figura 56 - Viabilidade celular obtida para cultura de osteoblastos em função do tempo na presença de discos de Ti sem modificações (preto) e modificados com filmes LB de DMPA/Ca ${ }^{2+}$ na ausência (cinza) e presença (branco) de TNAP imobilizada, a partir de monocamadas mistas com razão molar TNAP:DMPA 1:1400.

Possivelmente a diminuição da viabilidade celular foi maior para os filmes de DMPA/ $/ \mathrm{Ca}^{2+}$ (em relação aos filmes mistos com a enzima) devido uma maior quantidade de íons $\mathrm{Ca}^{2+}$ co-adsorvidos neste template. Como não há uma modificação muito significativa na proliferação dos osteoblastos sobre os filmes mistos contendo a enzima (frente à superfície controle de Ti), tal condição de imobilização da TNAP não foi capaz de promover uma sinalização celular que estimule uma indução na adesão e proliferação celular. Outros fatores poderiam ser avaliados em adição, tais como: atividade de fosfatase alcalina, proteína total e síntese de colágeno.

Finalmente, a morfologia das células cultivadas (em diferentes intervalos de tempo) sobre estas superfícies de Ti modificadas ou não com os filmes DMPA/Ca ${ }^{2+}$ (na ausência e presença de TNAP) foi caracterizada por MEV. As micrografias obtidas estão representadas nas Figura 57 e Figura 58. Foram obtidos recobrimentos de monocamadas celulares em todas as condições, sendo possível observar células com 
morfologias achatadas sobre as superfícies; indicando uma boa adesão destas nos suportes de Ti, tanto na ausência quanto na presença dos filmes LB.
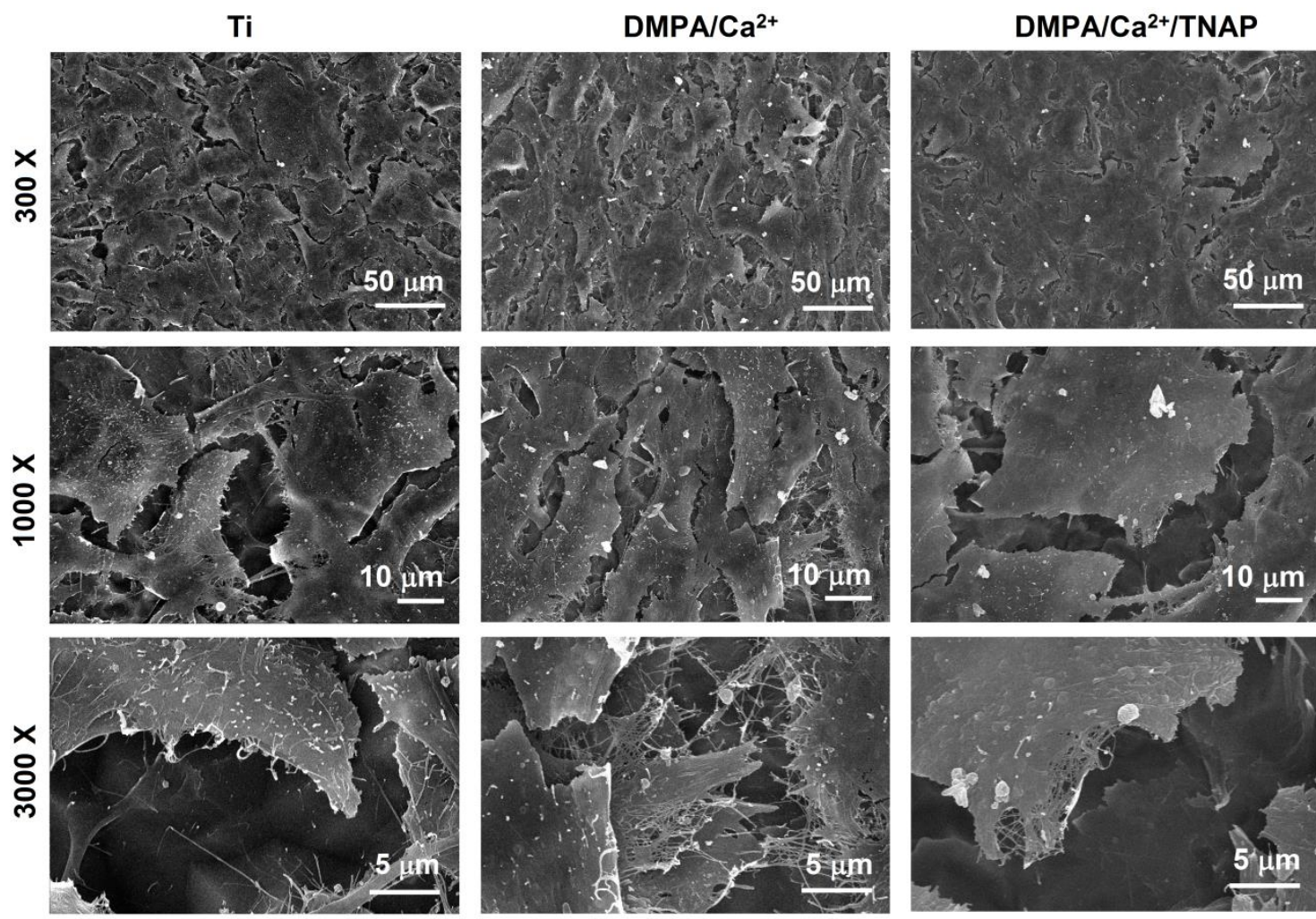

Figura 57 - Micrografias de MEV após 3 dias de cultura de osteoblastos sobre superfícies de Ti sem modificações e modificados com filmes LB de DMPA/Ca ${ }^{2+}$ na ausência e presença de TNAP imobilizada, a partir de monocamadas mistas com razão molar TNAP:DMPA 1:1400.

Como uma das propriedades interfaciais mais importantes na definição da morfologia e adesão celular é a $\gamma_{s}$, todas as superfícies em questão apresentaram-se hidrofílicas frente ao cultivo celular; até mesmo para os suportes de Ti não-modificados (de acordo com o valor de AC da água menor que $90^{\circ}$, relatado na Tabela 9), possivelmente devido ao tratamento superficial durante o preparo do suporte de Ti no plasma de argônio (aumento da hidrofilicidade ao introduzir grupos hidroxila aos óxidos superficiais do metal).

Após 3 dias de cultura celular (Figura 57), observa-se o extravasamento de fibras de colágeno e a formação de nódulos de mineralização de dimensões nanométricas de para as células cultivadas sobre as superfícies de Ti contendo o filme de DMPA/Ca ${ }^{2+} \mathrm{e}$ DMPA/ $\mathrm{Ca}^{2+} /$ TNAP. Este resultado indica que a modificação superficial com o filme promoveu uma indução na mineralização inicial das células osteogênicas cultivadas. 

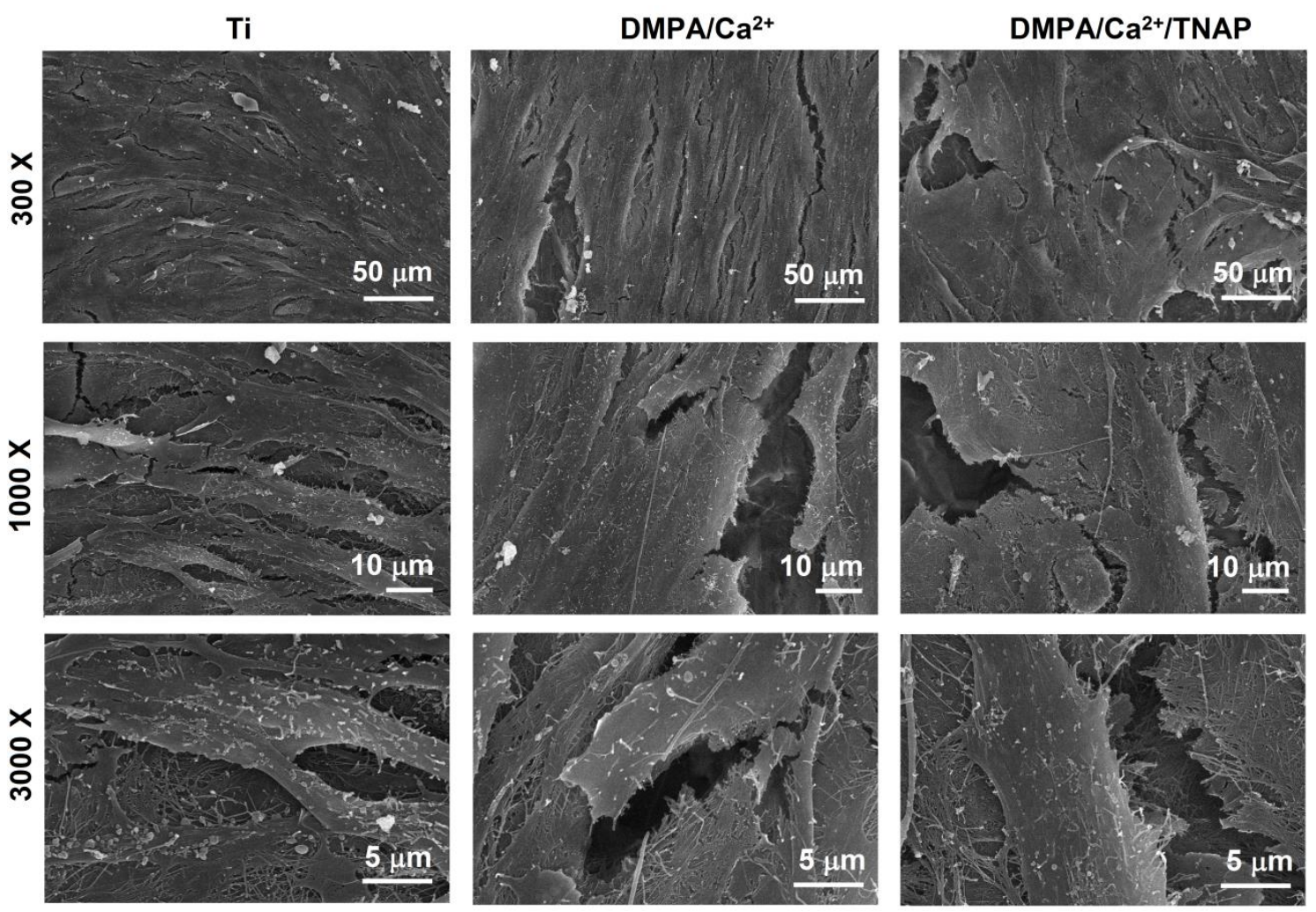

Figura 58 - Micrografias de MEV após 10 dias de cultura de osteoblastos sobre superfícies de Ti sem modificações e modificados com filmes LB de DMPA/Ca ${ }^{2+}$ na ausência e presença de TNAP imobilizada, a partir de monocamadas mistas com razão molar TNAP:DMPA 1:1400.

Após 10 dias de cultura celular (Figura 58), observa-se que as células encontramse em uma morfologia mais alongada, com a presença de nódulos de mineralização em todas as condições, como pode ser observado para maiores aumentos (3000x). Todas as células exibem extravasamento de matriz celular contendo fibras de colágeno.

Desta forma, não só o preparo da superfície de titânio (a fim de torna-la mais hidrofílica) como também sua modificação com os filmes LB são condições favoráveis para a adesão, proliferação e crescimento das células osteogênicas; permitindo a formação de uma monocamada celular que induz a formação de uma matriz celular proteica (majoritariamente constituída por colágeno) e posterior formação de minerais orientados pelas fibrilas proteicas. A presença de TNAP nos filmes parece não influenciar na diferenciação celular e no seu efeito mineralizador. 
Conclusões 


\section{Conclusões}

Dentre os diferentes tensoativos analisados, o DMPA foi escolhido na confecção de filmes devido à alta rigidez de suas monocamadas e sua capacidade de co-adsorver íons $\mathrm{Ca}^{2+}$ ao template $\mathrm{LB}$; a partir de uma subfase de $\mathrm{CaCl}_{2}$ de alta força iônica a fím de co-adsorver TNAP à monocamada. Foi possível realizar uma adsorção física desta enzima em filmes de DMPA/ $\mathrm{Ca}^{2+}$ sob um regime de monocamada da enzima, com uma atividade fosfohidrolítica correspondente a cerca de $7 \%$ em relação ao meio homogêneo. A formação dos filmes LB a partir das monocamadas mistas de DMPA/TNAP/Ca ${ }^{2+}$ promoveu um decréscimo ainda maior da atividade fosfohidrolítica. Apesar destas diminuições após a imobilização da enzima, a presença da mesma provocou uma maior indução de formação de mineral nos filmes LB. Observou-se a formação de uma fase mineral na superfície das amostras contendo a TNAP imobilizada nos filmes, constituída por fosfato de cálcio; uma vez que fora verificada a presença de bandas de estiramento referentes ao $\mathrm{PO}_{4}{ }^{3-}$ e presença do sinal do elemento $\mathrm{Ca}$ nos espectros de EDS. Esta fase mineral foi responsável pelo aumento da hidrofilicidade e molhabilidade da superfície modificada. O recobrimento superficial com os filmes LB, tanto na ausência quanto presença de TNAP, permitiram a adesão e proliferação de células osteogênicas.

Estes resultados demonstraram que a modificação de suportes de Ti com os filmes mistos de LB TNAP/DMPA não só induziram a formação de uma fase mineral, como também permitiram o crescimento de células essenciais na histogênese óssea. Foram ainda determinadas as proporções entre o lipídeo/TNAP ideais para otimizar sua atividade fosfohidrolítica e sua capacidade indutora na formação de minerais. Tais resultados indicaram que a metodologia abordada foi responsável por um aumento na bioatividade da superfície de $\mathrm{Ti}$, tornando-as possivelmente mais osteointegráveis. Portanto, os resultados aqui relatados servem como um ponto de partida para estudos futuros na modificação superficial de titânio baseadas nesta metodologia, a fim de construir materiais de implante ósseo com maior capacidade osteoindutora. 
Referências 


\section{Referências}

[1] J.C. Elliott, Calcium Phosphate Biominerals, Rev. Mineral. Geochemistry. 48 (2002) 427-453.

[2] H.C. Anderson, Matrix vesicles and calcification, Curr. Rheumatol. Rep. 5 (2003) 222-226.

[3] J. Caetano-Lopes, H. Canhão, J.E. Fonseca, Osteoblasts and bone formation., Acta Reum. Port. 32 (2007) 103-110.

[4] E.J. Mackie, Y.A. Ahmed, L. Tatarczuch, K.S. Chen, M. Mirams, Endochondral ossification: How cartilage is converted into bone in the developing skeleton, Int. J. Biochem. Cell Biol. 40 (2008) 46-62.

[5] E.J. Mackie, Osteoblasts: Novel roles in orchestration of skeletal architecture, Int. J. Biochem. Cell Biol. 35 (2003) 1301-1305.

[6] S.L. Teitelbaum, Bone Resorption by Osteoclasts, Science. 289 (2000) 15041508 .

[7] G.R. Mundy, T. a Guise, Hormonal control of calcium homeostasis., Clin. Chem. 45 (1999) 1347-1352.

[8] M.L. Knothe Tate, J.R. Adamson, A.E. Tami, T.W. Bauer, The osteocyte, Int. J. Biochem. Cell Biol. 36 (2004) 1-8.

[9] H. Boedtker, P. Doty, The Native and Denatured States of Soluble Collagen, J. Am. Chem. Soc. 78 (1956) 4267-4280.

[10] A. Miller, Collagen: the organic matrix of bone, Philos. Trans. R. Soc. B. (1984) $455-477$.

[11] K.A. Pies, M.S. Lewis, G.R. Martin, J. Gross, Subunits of the collagen molecule, Biochem. Biophys. Acta. 53 (1961) 596-598.

[12] J. De Yoreo, P.G. Vekilov, Principles of Crystal Nucleation and Growth, Rev. Mineral. Geochemistry. 54 (2003) 57-93.

[13] S. Rhee, J. Lee, J. Tanaka, Nucleation of hydroxyapatite crystal through chemical interaction with collagen, J. Am. Ceram. Soc. 92 (2000) 2890-2892.

[14] A. Posner, F. Betts, Synthetic amorphous calcium-phosphate and its relation to 
bone-mineral structure, Acc. Chem. Res. 8 (1975) 273-281.

[15] W.F. Neuman, B.J. Mulryan, Synthetic Hydroxyapatite Crystals, Calcif. Tissue Res. (1967) 94-104.

[16] R. Astala, M.J. Stott, First principles investigation of mineral component of bone: CO3 substitutions in hydroxyapatite, Chem. Mater. 17 (2005) 4125-4133.

[17] F. Barrère, C.A. Van Blitterswijk, K. de Groot, Bone regeneration : molecular and cellular interactions with calcium phosphate ceramics, Int. J. Nanomedicine. 1 (2006) 317-332.

[18] M. Iafisco, R. Bosco, S.C.G. Leeuwenburgh, J.J.J.P. Van Den Beucken, J.A. Jansen, M. Prat, N. Roveri, Electrostatic spray deposition of biomimetic nanocrystalline apatite coatings onto titanium, Adv. Eng. Mater. 14 (2012) 1320.

[19] A.S. Posner, R.A. Beebe, The surface chemistry of bone mineral and related calcium phosphates, Semin. Arthritis Rheum. 4 (1975) 267-291.

[20] M.J. Glimcher, L.C. Bonar, M.D. Grynpas, W.J. Landis, A.H. Roufosse, Recent studies of bone minerals: is the amorphous calcium phosphate theory valid?, J. Cryst. Growth. 53 (1981) 100-119.

[21] M.J. Glimcher, H. Muir, Recent Studies of the Mineral Phase in Bone and Its Possible Linkage to the Organic Matrix by Protein-Bound Phosphate Bonds [and Discussion], Philos. Trans. R. Soc. B. 304 (1984) 479-508.

[22] E.E. Golub, Role of matrix vesicles in biomineralization, Biochim. Biophys. Acta - Gen. Subj. 1790 (2009) 1592-1598.

[23] L. Cui, D.A. Houston, C. Farquharson, V.E. MacRae, Characterisation of Matrix Vesicles in Skeletal and Soft Tissue Mineralisation, Bone. (2016) 147-158.

[24] S.Y. Alit, S.W. Sajdera, H.C. Anderson, Isolation and Characterization of Calcifying Matrix Vesicles from Epiphyseal Cartilage, Proc. Natl. Acad. Sci. 67 (1970) 1513-1520.

[25] S.J. Roberts, A.J. Stewart, P.J. Sadler, C. Farquharson, Human PHOSPHO1 exhibits high specific phosphoethanolamine and phosphocholine phosphatase activities., Biochem. J. 382 (2004) 59-65.

[26] B. Houston, A.J. Stewart, C. Farquharson, PHOSPHO1 - A novel phosphatase 
specifically expressed at sites of mineralisation in bone and cartilage, Bone. 34 (2004) 629-637.

[27] A.L. Arsenault, B.W. Frankland, F.P. Ottensmeyer, Vectorial sequence of mineralization in the turkey leg tendon determined by electron microscopic imaging, Calcif. Tissue Int. 48 (1991) 46-55.

[28] W.N. Addison, F. Azari, E.S. Sørensen, M.T. Kaartinen, M.D. McKee, Pyrophosphate inhibits mineralization of osteoblast cultures by binding to mineral, up-regulating osteopontin, and inhibiting alkaline phosphatase activity., J. Biol. Chem. 282 (2007) 15872-83.

[29] E.E. Golub, K. Boesze-Battaglia, The role of alkaline phosphatase in mineralization., Curr. Opin. Orthop. 18 (2007) 444-448.

[30] M. Bollen, R. Gijsbers, H. Ceulemans, W. Stalmans, C. Stefan, Nucleotide pyrophosphatases/phosphodiesterases on the move., Crit. Rev. Biochem. Mol. Biol. 35 (2000) 393-432.

[31] L. Hessle, K.A. Johnson, H.C. Anderson, S. Narisawa, A. Sali, J.W. Goding, L. Milla, R. Terkeltaub, Tissue-nonspecific alkaline phosphatase and plasma cell membrane glycoprotein-1 are central antagonistic regulators of bone mineralization, Proc. Natl. Acad. Sci. U. S. A. 99 (2002) 9445-9449.

[32] A.M.S. Simão, M.C. Yadav, P. Ciancaglini, J.L. Millán, Proteoliposomes as matrix vesicles' biomimetics to study the initiation of skeletal mineralization Proteoliposomes as matrix vesicles' biomimetics to study the initiation of skeletal mineralization, Brazilian J. Med. Biol. Res. 43 (2010) 234 - 241.

[33] P. Ciancaglini, J.M. Pizauro, A.A. Rezende, L.A. Rezende, F.A. Leone, Solubilization of membrane-bound matrix-induced alkaline phosphatase with polyoxyethylene 9-lauryl ether (polidocanol): purification and metalloenzyme properties, Int. J. Biochem. 22 (1990) 385.

[34] J.L. Millán, Alkaline Phosphatases: Structure, substrate specificity and functional relatedness to other members of a large superfamily of enzymes., Purinergic Signal. 2 (2006) 335-341.

[35] E.E. Kim, H.W. Wyckoff, Reaction mechanism of alkaline phosphatase based on crystal structures, J. Mol. Biol. 218 (1991) 449-464. 
[36] E. Coleman, Structure and mechanism of alkaline phosphatase, Annu Rev Biophys. (1992) 441-483.

[37] M.H. Le Du, T. Stigbrand, M.J. Taussig, A. Menez, E. a Stura, Crystal structure of alkaline phosphatase from human placenta at $1.8 \mathrm{~A}$ resolution. Implication for a substrate specificity., J. Biol. Chem. 276 (2001) 9158-65.

[38] E. Mornet, E. Stura, a S. Lia-Baldini, T. Stigbrand, A. Ménez, M.H. Le Du, Structural evidence for a functional role of human tissue nonspecific alkaline phosphatase in bone mineralization., J. Biol. Chem. 276 (2001) 31171-8.

[39] F.A. Leone, P. Ciancaglini, J.M. Pizauro, Effect of calcium ions on rat osseous plate alkaline phosphatase activity, J. Inorg. Biochem. 68 (1997) 123-127.

[40] M.N. Lucena, J.C. McNamara, F.A. Leone, Gill (Na+, K+)-ATPase from the Amazon River shrimp, Macrobrachium amazonicum (Decapoda, Palaemonidae): effect of exogenous biogenic amines on enzyme activity in juveniles and adults, Hydrobiologia. (2016) 1-18.

[41] H. Ikezawa, Glycosylphosphatidylinositol (GPI)-Anchored Proteins, Biol. Pharm. Bull. 25 (2002) 409-417.

[42] A. Müller, C. Klöppel, M. Smith-Valentine, J. Van Houten, M. Simon, Selective and programmed cleavage of GPI-anchored proteins from the surface membrane by phospholipase C, Biochim. Biophys. Acta - Biomembr. 1818 (2012) 117-124.

[43] R. Fortuna, H. Clarke Anderson, R.P. Carty, S.W. Sajdera, The purification and molecular characterization of alkaline phosphatases from chondrocytes and matrix vesicles of bovine fetal epiphyseal cartilage, Metab. Bone Dis. Relat. Res. 1 (1978) 161-168.

[44] G.W. Cyboron, R.E. Wuthier, Purification and initial characterization of intrinsic membrane-bound alkaline phosphatase from chicken epiphyseal cartilage., J. Biol. Chem. 256 (1981) 7262-7268.

[45] A. Piattelli, A. Scarano, M. Corigliano, M. Piattelli, Effects of alkaline phosphatase on bone healing around plasma-sprayed titanium implants: a pilot study in rabbits, Biomaterials. 17 (1996) 1443-1449.

[46] A. Piattelli, A. Scarano, M. Piattelli, Detection of alkaline and acid phosphatases around titanium implants: a light microscopical and histochemical study in 
rabbits, Biomaterials. 16 (1995) 1333-1338.

[47] T. Kokubo, H.-M. Kim, M. Kawashita, T. Nakamura, Bioactive metals: preparation and properties, J. Mater. Sci. Mater. Med. 15 (2004) 99-107.

[48] L.L. Hench, Bioceramics: From Concept to Clinic, J. Am. Ceram. Soc. 74 (1991) $1487-1510$.

[49] L.F.B. Nogueira, B.C. Maniglia, L.S. Pereira, D.R. Tapia-Blácido, A.P. Ramos, Formation of carrageenan-CaCO3 bioactive membranes, Mater. Sci. Eng. C. 58 (2016) 1-6.

[50] W. Cao, L.L. Hench, Bioactive materials, Ceram. Int. 22 (1996) 493-507.

[51] A. Kurella, Review paper: Surface Modification for Bioimplants: The Role of Laser Surface Engineering, Journal of Biomaterials Applications 20 (2005) 5-50.

[52] M. Tirrell, E. Kokkoli, M. Biesalski, The role of surface science in bioengineered materials, Surf. Sci. 500 (2002) 61-83.

[53] V. Pešáková, D. Kubies, H. Hulejová, L. Himmlová, The influence of implant surface properties on cell adhesion and proliferation, J. Mater. Sci. Mater. Med. 18 (2007) 465-473.

[54] B. Groessner-Schreiber, A. Neubert, W.-D. Müller, M. Hopp, M. Griepentrog, K.-P. Lange, Fibroblast growth on surface-modified dental implants: an in vitro study., J. Biomed. Mater. Res. A. 64 (2003) 591-599.

[55] S.R. Radin, P. Ducheyne, Effect of bioactive ceramic composition and structure on in vitro behavior. III. Porous versus dense ceramics, J. Biomed. Mater. Res. 28 (1994) 1303-1309.

[56] J.Y. Martin, Z. Schwartz, T.W. Hummert, D.M. Schraub, J. Simpson, J. Lankford, D.D. Dean, D.L. Cochran, B.D. Boyan, Effect of titanium surface roughness on proliferation, differentiation, and protein synthesis of human osteoblast-like cells (MG63), J. Biomed. Mater. Res. 29 (1995) 389-401.

[57] R.A. Surmenev, A review of plasma-assisted methods for calcium phosphatebased coatings fabrication, Surf. Coatings Technol. 206 (2012) 2035-2056.

[58] H.. Hsu, S.. Yen, Evaluation of metal ion release and corrosion resistance of ZrO2 thin coatings on the dental Co-Cr alloys, Dent. Mater. 14 (1998) 339-346.

[59] M. Kheirkhah, M. Fathi, H.R. Salimijazi, M. Razavi, Surface modification of 
stainless steel implants using nanostructured forsterite (Mg2SiO4) coating for biomaterial applications, Surf. Coatings Technol. 276 (2015) 580-586.

[60] H.W. Kim, Y.H. Koh, L.H. Li, S. Lee, H.E. Kim, Hydroxyapatite coating on titanium substrate with titania buffer layer processed by sol-gel method, Biomaterials. 25 (2004) 2533-2538.

[61] I.D. de Souza, M. a E. Cruz, A.N. de Faria, D.C. Zancanela, A.M.S. Simão, P. Ciancaglini, A.P. Ramos, Formation of carbonated hydroxyapatite films on metallic surfaces using dihexadecyl phosphate-LB film as template., Colloids Surf. B. Biointerfaces. 118 (2014) 31-40.

[62] M.A.E. Cruz, G.C.M. Ruiz, A.N. Faria, D.C. Zancanela, L.S. Pereira, P. Ciancaglini, A.P. Ramos, Calcium carbonate hybrid coating promotes the formation of biomimetic hydroxyapatite on titanium surfaces, Appl. Surf. Sci. 370 (2016) 459-468.

[63] L.J. Zhang, H.G. Liu, R.J. Zhang, L. Zhang, D.J. Qian, Y. Di Mu, X.L. Yu, X.S. Feng, The mineralization process of calcium phosphate induced by the LB films of porphyrin, Colloids Surfaces A Physicochem. Eng. Asp. 257-258 (2005) 307312.

[64] V.M. Kaganer, H. Möhwald, P. Dutta, Structure and phase transitions in Langmuir monolayers, Rev. Mod. Phys. 71 (1999) 779-819.

[65] A. Dhanabalan, D.T. Balogh, C.R. Mendonça, A. Riul, C.J.L. Constantino, J.A. Giacometti, S.C. Zilio, O.N. Oliveira, Mixed Langmuir and Langmuir-Blodgett Films of Disperse Red-13 Dye-Derivatized Methacrylic Homopolymer and Cadmium Stearate, Langmuir. 14 (1998) 3614-3619.

[66] A.M. Barros, A. Dhanabalan, C.J.L. Constantino, D.T. Balogh, O.N. Oliveira, Langmuir monolayers of lignins obtained with different isolation methods, Thin Solid Films. 354 (1999) 215-221.

[67] G. Thakur, C. Wang, R.M. Leblanc, Surface Chemistry and in Situ Spectroscopy of a Lysozyme Langmuir Monolayer, Langmuir. 24 (2008) 4888-4893.

[68] L. Caseli, D.C. Masui, R.P.M. Furriel, F.A. Leone, M.E.D. Zaniquelli, J. Orbulescu, R.M. Leblanc, Rat osseous plate alkaline phosphatase as Langmuir monolayer-an infrared study at the air-water interface, J. Colloid Interface Sci. 320 (2008) 476-482. 
[69] P.B. Miranda, Q. Du, Y.R. Shen, Interaction of water with a fatty acid Langmuir film, Chem. Phys. Lett. 286 (1998) 1-8.

[70] E. Loste, E. Díaz-Martí, A. Zarbakhsh, F.C. Meldrum, Study of calcium carbonate precipitation under a series of fatty acid langmuir monolayers using brewster angle microscopy, Langmuir. 19 (2003) 2830-2837.

[71] A. Fischer, M. Lösche, H. Möhwald, E. Sackmann, On the nature of the lipid monolayer phase transition, J. Phys. Lettres. 45 (1984) 785-791.

[72] R. Maget-Dana, M. Ptak, Interactions of surfactin with membrane models., Biophys. J. 68 (1995) 1937-43.

[73] V.P.N. Geraldo, F.J. Pavinatto, T.M. Nobre, L. Caseli, O.N. Oliveira, Langmuir films containing ibuprofen and phospholipids, Chem. Phys. Lett. 559 (2013) 99106.

[74] A.M. Gonçalves da Silva, R.I.S. Romão, Mixed monolayers involving DPPC, DODAB and oleic acid and their interaction with nicotinic acid at the air-water interface., Chem. Phys. Lipids. 137 (2005) 62-76.

[75] P. Toimil, G. Prieto, J. Miñones, F. Sarmiento, A comparative study of FDPPC/DPPC mixed monolayers. Influence of subphase temperature on F-DPPC and DPPC monolayers., Phys. Chem. Chem. Phys. 12 (2010) 13323-32.

[76] D. Vollhardt, V.B. Fainerman, Progress in characterization of Langmuir monolayers by consideration of compressibility., Adv. Colloid Interface Sci. 127 (2006) 83-97.

[77] J.T. Davies, E.K. Rideal, Interfacial Phenomena, 1963.

[78] K.J. Stine, Investigations of monolayers by fluorescence microscopy., Microsc. Res. Tech. 27 (1994) 439-450.

[79] M. Heckl, H. Mohwald, A Narrow Window for Observation of Spiral Lipid Crystals, Berichte Der Bunsengesellschaft Für Phys. Chemie. 90 (1986) 11591163.

[80] J.P. Slotte, P. Mattjus, Visualization of lateral phases in cholesterol and phosphatidylcholine monolayers at the air/water interface - a comparative study with two different reporter molecules, Biochim. Biophys. Acta (BBA)/Lipids Lipid Metab. 1254 (1995) 22-29. 
[81] B.L. Stottrup, S. Keller, Phase behavior of lipid monolayers containing DPPC and cholesterol analogs., Biophys. J. 90 (2006) 3176-3183.

[82] L.A. Worthman, K. Nag, P.J. Davis, K.M. Keough, Cholesterol in condensed and fluid phosphatidylcholine monolayers studied by epifluorescence microscopy., Biophys. J. 72 (1997) 2569-2580.

[83] L. Caseli, D.C. Masui, R.P.M. Furriel, F. a Leone, M.E.D. Zaniquelli, Incorporation conditions guiding the aggregation of a glycosylphosphatidyl inositol (GPI)-anchored protein in Langmuir monolayers, Colloids Surf. B. Biointerfaces. 46 (2005) 248-54.

[84] L. Caseli, R.G. Oliveira, D.C. Masui, R.P.M. Furriel, F.A. Leone, B. Maggio, M.E.D. Zaniquelli, Effect of Molecular Surface Packing on the Enzymatic Activity Modulation of an Anchored Protein on Phospholipid Langmuir Monolayers, Langmuir. 21 (2005) 4090-4095.

[85] H. Mohwald, Phospholipid and Phospholipid-Protein Monolayers At the Air/Water Interface, Annu. Rev. Phys. Chem. 41 (1990) 441-76.

[86] J. Meunier, Why a Brewster angle microscope?, Colloids Surfaces A Physicochem. Eng. Asp. 171 (2000) 33-40.

[87] H. Diamant, T.A. Witten, C. Ege, A. Gopal, K.Y. Lee, Topography and instability of monolayers near domain boundaries., Phys. Rev. E. Stat. Nonlin. Soft Matter Phys. 63 (2001) 061602.

[88] C.M. Castro, M. Pinheiro, M. Lúcio, J.J. Giner-Casares, L. Camacho, J.L.F.C. Lima, S. Reis, M.A. Segundo, Insights about $\alpha$-tocopherol and Trolox interaction with phosphatidylcholine monolayers under peroxidation conditions through Brewster angle microscopy, Colloids Surfaces B Biointerfaces. 111 (2013) 626635.

[89] R.B. Weinberg, J.A. Ibdah, M.C. Phillips, Adsorption of apolipoprotein A-IV to phospholipid monolayers spread at the air/water interface. A model for its labile binding to high density lipoproteins, J. Biol. Chem. 267 (1992) 8977-8983.

[90] A. Kouzayha, F. Besson, GPI-alkaline phosphatase insertion into phosphatidylcholine monolayers: phase behavior and morphology changes, Biochem. Biophys. Res. Commun. 333 (2005) 1315-1321. 
[91] F. Ronzon, B. Desbat, J.-P. Chauvet, B. Roux, Penetration of a GPI-anchored protein into phospholipid monolayers spread at the air/water interface, Colloids Surfaces B Biointerfaces. 23 (2002) 365-373.

[92] J. Zhao, X. Zhao, Z. Jiang, Z. Li, X. Fan, J. Zhu, H. Wu, Y. Su, D. Yang, F. Pan, J. Shi, Biomimetic and bioinspired membranes: Preparation and application, Prog. Polym. Sci. 39 (2014) 1668-1720.

[93] P. Vermette, L. Meagher, Interactions of phospholipid- and poly(ethylene glycol)-modified surfaces with biological systems: Relation to physico-chemical properties and mechanisms, Colloids Surfaces B Biointerfaces. 28 (2003) 153198.

[94] R.L. Biltonen, D. Lichtenberg, The use of differential scanning calorimetry as a tool to characterize liposome preparations, Chem. Phys. Lipids. 64 (1993) 129142.

[95] R.K. Banerjee, A.G. Datta, Proteoliposome as the model for the study of membrane-bound enzymes and transport proteins, Mol. Cell. Biochem. 50 (1983) $3-15$.

[96] H.-H. Shen, T. Lithgow, L. Martin, Reconstitution of membrane proteins into model membranes: seeking better ways to retain protein activities., Int. J. Mol. Sci. 14 (2013) 1589-607.

[97] A.M.S. Simão, M.C. Yadav, S. Narisawa, M. Bolean, J.M. Pizauro, M.F. Hoylaerts, P. Ciancaglini, J.L. Millán, Proteoliposomes harboring alkaline phosphatase and nucleotide pyrophosphatase as matrix vesicle biomimetics., J. Biol. Chem. 285 (2010) 7598-7609.

[98] A.M.S. Simão, M. Bolean, M.F. Hoylaerts, J.L. Millán, P. Ciancaglini, Effects of $\mathrm{pH}$ on the production of phosphate and pyrophosphate by matrix vesicles' biomimetics., Calcif. Tissue Int. 93 (2013) 222-32.

[99] B.R. Genge, L.N.Y. Wu, R.E. Wuthier, In vitro modeling of matrix vesicle nucleation: synergistic stimulation of mineral formation by annexin A5 and phosphatidylserine., J. Biol. Chem. 282 (2007) 26035-45.

[100] H. Brockman, Lipid monolayers: Why use half a membrane to characterize protein-membrane interactions?, Curr. Opin. Struct. Biol. 9 (1999) 438-443. 
[101] A. Seelig, Local anesthetics and pressure: a comparison of dibucaine binding to lipid monolayers and bilayers, BBA - Biomembr. 899 (1987) 196-204.

[102] P. Nordera, M.D. Serra, G. Menestrina, The adsorption of Pseudomonas aeruginosa exotoxin A to phospholipid monolayers is controlled by $\mathrm{pH}$ and surface potential., Biophys. J. 73 (1997) 1468-78.

[103] J.M. Rocha, L. Caseli, Adsorption and enzyme activity of sucrose phosphorylase on lipid Langmuir and Langmuir-Blodgett films., Colloids Surf. B. Biointerfaces. 116 (2014) 497-501.

[104] I. Langmuir, V.J. Schaefer, Salted-Out Protein Films, J. Am. Chem. Soc. 60 (1938) 2803-2810.

[105] L. Dziri, K. Puppala, R.M. Leblanc, Surface and Spectroscopic Properties of Acetylcholinesterase Monolayer at the Air/Water Interface, J. Colloid Interface Sci. 194 (1997) 37-43.

[106] L. Caseli, M.E.D. Zaniquelli, R.P.M. Furriel, F.A. Leone, Enzymatic activity of alkaline phosphatase adsorbed on dimyristoylphosphatidic acid LangmuirBlodgett films, Colloids Surfaces B Biointerfaces. 25 (2002) 119-128.

[107] L. Caseli, M.E.D. Zaniquelli, R.P.M. Furriel, F.A. Leone, Adsorption of detergent-solubilized and phospholipase C-solubilized alkaline phosphatase at air/liquid interfaces, Colloids Surfaces B Biointerfaces. 30 (2003) 273-282.

[108] L. Caseli, R.P.M. Furriel, J.F. de Andrade, F.A. Leone, M.E.D. Zaniquelli, Surface density as a significant parameter for the enzymatic activity of two forms of alkaline phosphatase immobilized on phospholipid Langmuir-Blodgett films, J. Colloid Interface Sci. 275 (2004) 123-30.

[109] L. Caseli, D.C. Masui, R.P.M. Furriel, F.A. Leone, M.E.D. Zaniquelli, Influence of the glycosylphosphatidylinositol anchor in the morphology and roughness of Langmuir-Blodgett films of phospholipids containing alkaline phosphatases, Thin Solid Films. 515 (2007) 4801-4807.

[110] L. Caseli, D.C. Masui, R.P.M. Furriel, F.A. Leone, M.E.D. Zaniquelli, Adsorption Kinetics and Dilatational Rheological Studies for the Soluble and Anchored Forms of Alkaline Phosphatase at the Air / Water Interface, J. Braz. Chem. Soc. 16 (2005) 969-977. 
[111] T.I. Lotta, L.J. Laakkonen, J.A. Virtanen, P.K.J. Kinnunen, Characterization of Langmuir Blodgett films of phosphatidylcholine by FTIR-ATR, Chem. Phys. Lipids. 46 (1988) 1-12.

[112] Y. Li, C. Zhu, J. Zhu, H. Liang, D. Chen, H. Zhao, B. Liu, Nanomechanics of phospholipid LB film studied layer by layer with AFM, Chem. Cent. J. 8 (2014) 71.

[113] F. Yin, S.H. Park, H.K. Shin, Y.S. Kwon, Study of hemoglobin-octadecylamine LB film formation and deposition by compressibility analyse, QCM and AFM, Curr. Appl. Phys. 6 (2006) 728-734.

[114] A.P. Girard-Egrot, S. Godoy, L.J. Blum, Enzyme association with lipidic Langmuir-Blodgett films: interests and applications in nanobioscience., Adv. Colloid Interface Sci. 116 (2005) 205-25.

[115] T. Kokubo, H. Takadama, How useful is SBF in predicting in vivo bone bioactivity?, Biomaterials. 27 (2006) 2907-2915.

[116] A. Piattelli, A. Scarano, M. Corigliano, M. Piattelli, Effects of alkaline phosphatase on bone healing around plasma-sprayed titanium implants: a pilot study in rabbits, Biomaterials. 17 (1996) 1443-1449.

[117] D.A. Puleo, A. Nanci, Understanding and controlling the bone-implant interface, Biomaterials. 20 (1999) 2311-2321.

[118] O.N. Oliveira Jr., Langmuir-Blodgett Films - Properties and Possible Applications, Brazilian J. Phys. 22 (1992) 60-69.

[119] F.C. Correia, S.H. Wang, L.O. Péres, L. Caseli, Langmuir and LangmuirBlodgett films of a quinoline-fluorene based copolymer, Colloids Surfaces A Physicochem. Eng. Asp. 394 (2012) 67-73.

[120] A.M. Yashchenok, D. a. Gorin, K.E. Pankin, M. V. Lomova, S.N. Shtykov, B.N. Klimov, G.I. Kurochkina, M.K. Grachev, Transfer ratio of Langmuir-Blodgett films as an indicator of the single-crystal silicon surface modified by polyionic layers, Semiconductors. 41 (2007) 684-688.

[121] Y. Okahata, K. Ariga, K. Tanaka, Evaluation of a horizontal lifting method of Langmuir-Blodgett films using a quartz-crystal microbalance, Thin Solid Films. 210-211 (1992) 702-706. 
[122] G. Sauerbrey, Verwendung von Schwingquarzen zur Wägung dünner Schichten und zur Mikrowägung, Zeitschrif Für Phys. 155 (1959) 206 - 222.

[123] S. Garcia-Manyes, G. Oncins, F. Sanz, Effect of ion-binding and chemical phospholipid structure on the nanomechanics of lipid bilayers studied by force spectroscopy., Biophys. J. 89 (2005) 1812-1826.

[124] R.K. Gupta, K.A. Suresh, AFM studies on Langmuir-Blodgett films of cholesterol, Eur. Phys. J. E. 14 (2004) 35-42.

[125] A.P. Ramos, C. Pavani, Y. Iamamoto, M.E.D. Zaniquelli, Porphyrinphospholipid interaction and ring metallation depending on the phospholipid polar head type., J. Colloid Interface Sci. 350 (2010) 148-54.

[126] V. Hartmann, M. Losche, S. V Mello, O.N.O. Jr, UV/Vis and SFM studies on Langmuir monolayers and Langmuir-Blodgett films of 16-mer aniline and opentadecylaniline blends, Mater. Sci. Eng. C. 8 (1999) 425-429.

[127] F. Kimura, J. Umemura, T. Takenaka, FTIR-ATR Studies on Langmuir-Blodgett Films of Stearic Acid with 1-9 Monolayers, Langmuir. 2 (1986) 96-101.

[128] S. Pang, C. Li, J. Huang, Y. Liang, FTIR studies on Langmuir-Blodgett (LB) films of amphiphile with Schiff base moiety as headgroup, Mater. Sci. Eng. C. 11 (2000) 137-143.

[129] J.M. Chovelon, M. Provence, N. Jaffrezic-renault, S. Alexandre, J.M. Valleton, Transfer of mixed protein - fatty acid LB films onto $\mathrm{Si} / \mathrm{SiO} 2$ substrates . Influence of the surface free energy, Mater. Sci. 22 (2002) $79-85$.

[130] M.B. Thürmer, P. Poletto, M. Marcolin, J. Duarte, M. Zeni, Effect of nonsolvents used in the coagulation bath on morphology of PVDF membranes, Mater. Res. 15 (2012) 884-890.

[131] D.K. Owens, R.C. Wendt, Estimation of the surface free energy of polymers, J. Appl. Polym. Sci. 13 (1969) 1741-1747.

[132] Y. Rotenberg, L. Boruvka, A.W. Newmann, Determination of Surface Tension and Contact Angle from the Shapes of Axisymmetric Fluid Interfaces, J. Colloid Interface Sci. 93 (1983) 169-183.

[133] J.D. Berry, M.J. Neeson, R.R. Dagastine, D.Y.C. Chan, R.F. Tabor, Measurement of surface and interfacial tension using pendant drop tensiometry, 


\section{J. Colloid Interface Sci. 454 (2015) 226-237.}

[134] M.A.R. Andrade, B. Favarin, R. Derradi, M. Bolean, A.M.S. Simão, J.L. Millán, P. Ciancaglini, A.P. Ramos, Pendant-drop method coupled to ultraviolet-visible spectroscopy: a useful tool to investigate interfacial phenomena, Colloids Surfaces A Physicochem. Eng. Asp. (2016) 305-311.

[135] F.L. Camolezi, K.R.P. Daghastanli, P.P. Magalhães, J.M. Pizauro, P. Ciancaglini, Construction of an alkaline phosphatase-liposome system: a tool for biomineralization study, Int. J. Biochem. Cell Biol. 34 (2002) 1091-1101.

[136] E.F. Hartree, Determination of protein: A modification of the lowry method that gives a linear photometric response, Anal. Biochem. 48 (1972) 422-427.

[137] M. Rouahi, E. Champion, P. Hardouin, K. Anselme, Quantitative kinetic analysis of gene expression during human osteoblastic adhesion on orthopaedic materials, Biomaterials. 27 (2006) 2829-2844.

[138] R.D. Herculano, F.J. Pavinatto, L. Caseli, C. D’Silva, O.N. Oliveira, The lipid composition of a cell membrane modulates the interaction of an antiparasitic peptide at the air-water interface, Biochim. Biophys. Acta - Biomembr. 1808 (2011) 1907-1912.

[139] K. Hạc-Wydro, P. Wydro, P. Dynarowicz-ŁA̧tka, Interactions between dialkyldimethylammonium bromides (DXDAB) and sterols - A monolayer study, J. Colloid Interface Sci. 286 (2005) 504-510.

[140] A.M. Gonçalves Da Silva, R.S. Romão, A. Lucero Caro, J.M. Rodríguez Patino, Memory effects on the interfacial characteristics of dioctadecyldimethylammonium bromide monolayers at the air-water interface, J. Colloid Interface Sci. 270 (2004) 417-425.

[141] A. Cavalli, P. Dynarowicz-Latka, O.N. Oliveira, E. Feitosa, Using an effective surface charge to explain surface potentials of Langmuir monolayers from dialkyldimethylammonium halides with the Gouy-Chapman theory, Chem. Phys. Lett. 338 (2001) 88-94.

[142] K. Universip, Molecular orientation in thin Langmuir-Blodgett films of dipalmitoylphosphatidylcholine as studied by FTIR transmission and reflectionabsorption spectroscopy, Canadian Journal of Chemistry 69 (1991) 1961-1964. 
[143] K. Kim, C. Kim, Y. Byun, Preparation of a dipalmitoylphosphatidylcholine/cholesterol Langmuir-Blodgett monolayer that suppresses protein adsorption, Langmuir. 17 (2001) 5066-5070.

[144] K. Iso, T. Okada, Evaluation of electrostatic potential induced by aniondominated partition into zwitterionic micelles and origin of selectivity in anion uptake, Langmuir. 16 (2000) 9199-9204.

[145] N.N. Casillas-Ituarte, X. Chen, H. Castada, H.C. Allen, Na+ and Ca2+ effect on the hydration and orientation of the phosphate group of DPPC at air - Water and air - Hydrated silica interfaces, J. Phys. Chem. B. 114 (2010) 9485-9495.

[146] M. Sovago, G.W.H. Wurpel, M. Smits, M. Müller, M. Bonn, Calcium-induced phospholipid ordering depends on surface pressure, J. Am. Chem. Soc. 129 (2007) 11079-11084.

[147] J.J. Giner-Casares, L. Camacho, M.T. Martın-Romero, J.J.L. Cascales, M.T. Martín-Romero, J.J.L. Cascales, A DMPA Langmuir Monolayer Study: From Gas to Solid Phase. An Atomistic Description by Molecular Dynamics Simulation, Langmuir. 24 (2008) 1823-1828.

[148] M. Schalke, P. Krüger, M. Weygand, M. Lösche, Submolecular organization of DMPA in surface monolayers: Beyond the two-layer model, Biochim. Biophys. Acta - Biomembr. 1464 (2000) 113-126.

[149] W. Bu, K. Flores, J. Pleasants, D. Vaknin, Preferential Affinity of Calcium Ions to Charged Phosphatidic Acid Surface from a Mixed Calcium / Barium Solution : X-ray Reflectivity and Fluorescence Studies Preferential Affinity of Calcium Ions to Charged Phosphatidic Acid Surface from a Mixed Calcium, Langmuir. 25 (2009) 1068-1073.

[150] D. Vaknin, P. Krüger, M. Lösche, Anomalous X-ray reflectivity characterization of ion distribution at biomimetic membranes., Phys. Rev. Lett. 90 (2003) 178102.

[151] M. Sammalkorpi, M. Karttunen, M. Haataja, Ionic surfactant aggregates in saline solutions: Sodium dodecyl sulfate (SDS) in the presence of excess sodium chloride $(\mathrm{NaCl})$ or calcium chloride $(\mathrm{CaCl} 2)$, J. Phys. Chem. B. 113 (2009) $5863-5870$.

[152] J. Faraudo, A. Travesset, Electrostatics of phosphatidic acid monolayers: Insights from computer simulations, Colloids Surfaces A Physicochem. Eng. Asp. 300 
(2007) 287-292.

[153] K. Gong, S.-S. Feng, M.L. Go, P.H. Soew, Effects of pH on the stability and compressibility of DPPC/cholesterol monolayers at the air-water interface, Colloids Surfaces A Physicochem. Eng. Asp. 207 (2002) 113-125.

[154] P. Ciancaglini, J. Martins Pizauro, F.A. Leone, Mechanism of action of cobalt ions on rat osseous plate alkaline phosphatase, J. Inorg. Biochem. 60 (1995) 155162.

[155] H. Zhang, X. Wang, G. Cui, J. Li, Stability investigation of the mixed DPPC/protein monolayer at the air-water interface, Colloids Surfaces A Physicochem. Eng. Asp. 175 (2000) 77-82.

[156] A.K.M. Kafi, Y.S. Kwon, Brewster angle microscopic study of mixed lipidprotein monolayer at the air-water interface and its application in biosensing, Talanta. 76 (2008) 1029-1034.

[157] F. Ronzon, B. Desbat, J.-P. Chauvet, B. Roux, Behavior of a GPI-anchored protein in phospholipid monolayers at the air-water interface, Biochim. Biophys. Acta - Biomembr. 1560 (2002) 1-13.

[158] L. Caseli, Influência da Âncora de Glicosilfosfatidilinositol na Imobilização da Fosfatase Alcalina Imobilizada em Sistemas Miméticos de Membranas Celulares: Monocamadas de Langmuir e Filmes Langmuir-Blodgett de Fosfolipídios, Tese Doutorado, Departamento Química, FFCLRP-USP (2005) 1-157.

[159] M. Bolean, A.M.S. Simão, B.Z. Favarin, J.L. Millán, P. Ciancaglini, The effect of cholesterol on the reconstitution of alkaline phosphatase into liposomes, Biophys. Chem. 152 (2010) 74-79.

[160] A. Petrigliano, A. Tronin, C. Nicolini, Deposition and enzymatic activity of Langmuir-Blodgett films of alkaline phosphatase, Thin Solid Films. 284-285 (1996) 752-756.

[161] S. Pina, J.M. Oliveira, R.L. Reis, Natural-based nanocomposites for bone tissue engineering and regenerative medicine: A review, Adv. Mater. 27 (2015) 11431169.

[162] S. Meejoo, W. Maneeprakorn, P. Winotai, Phase and thermal stability of nanocrystalline hydroxyapatite prepared via microwave heating, Thermochim. 
Acta. 447 (2006) 115-120.

[163] B.O. Fowler, E.C. Moreno, W.E. Brown, Infra-red spectra of hydroxyapatite, octacalcium phosphate and pyrolysed octacalcium phosphate., Arch. Oral Biol. 11 (1966) 477-492.

[164] J.K. Han, H.Y. Song, F. Saito, B.T. Lee, Synthesis of high purity nano-sized hydroxyapatite powder by microwave-hydrothermal method, Mater. Chem. Phys. 99 (2006) 235-239. 